JORGE CAVALCANTI BOUCINHAS FILHO

\title{
DISCRIMINAÇÃO POR SOBREQUALIFICAÇÃO
}

Dissertação de Mestrado

Orientador: Professor Associado Antônio Rodrigues de Freitas Júnior

UNIVERSIDADE DE SÃO PAULO

FACULDADE DE DIREITO

São Paulo-SP

2008. 
JORGE CAVALCANTI BOUCINHAS FILHO

\section{DISCRIMINAÇÃO POR SOBREQUALIFICAÇÃO}

Dissertação apresentada à Banca Examinadora da Faculdade de Direito da Universidade de São Paulo como requisito parcial para obtenção do título de Mestre em Direito do Trabalho, elaborada sob a orientação do Professor Associado Antônio Rodrigues de Freitas Júnior.

São Paulo-SP

2008. 
JORGE CAVALCANTI BOUCINHAS FILHO

\section{DISCRIMINAÇÃO POR SOBREQUALIFICAÇÃO}

Dissertação apresentada à Banca Examinadora da Faculdade de Direito da Universidade de São Paulo como requisito parcial para obtenção do título de Mestre em Direito do Trabalho.

Data de Aprovação:

Nome:

Título:

Instituição:

Nome:

Título:

Instituição:

Nome:

Título:

Instituição: 
Aos meus pais, Jorge e Ilane, que desde cedo me ensinaram a não acreditar na existência de sonhos impossíveis de serem realizados. 


\section{AGRADECIMENTOS}

Ao Professor Antonio Rodrigues de Freitas Júnior pela oportunidade que me foi concedida, pela costumeira atenção e deferência, por ter acreditado neste projeto e por suas valiosas orientações.

Ao Professor Estêvão Mallet e à sua inseparável esposa Olinda Mallet, pela paciência, confiança, compreensão e, sobretudo, pelo apoio e pelo incentivo para que este projeto fosse concretizado.

Aos Professores Jorge Luiz Souto Maior, Paulo Eduardo Vieira de Oliveira, Ari Possidônio Beltran, Marcus Orione Gonçalves Correia, Otávio Pinto e Silva, Edílson Pereira Nobre Júnior, Edílson França, Walter Nunes da Silva Júnior, Francisco Barros Dias, Maria do Perpétuo Socorro Wanderley de Castro, Rossana Mary Sudário e Henrique Baltazar Vilar dos Santos, pelas lições de Direito e pelos exemplos de vida.

Aos Procuradores José de Lima Ramos Pereira, Izabel Christina Baptista Queiróz Ramos, Xisto Tiago de Medeiros Neto, José Diniz de Morais e Rosivaldo da Cunha Oliveira, bem como aos demais membros e servidores do Ministério Público do Trabalho da $21^{\text {a }}$ Região, pela costumeira cordialidade, generosidade e atenção.

Aos colegas do escritório e da Universidade, pela harmoniosa convivência diária.

Aos casais Arnaldo e Cidinha Acayaba de Toledo, Vicente e Mônica Morato e Andrei Fernandes e Bernadete Figueiredo Dias, pelo acolhimento, hospitalidade e apoio.

Aos professores Carlos Augusto Andrade e Adriano de Assis Ferreira pela confiança e pelas oportunidades que me foram dadas. 
Aos meus alunos passados, presentes e futuros por tudo o que com eles aprendi, aprendo e aprenderei.

Aos meus amigos, pelo privilégio de assim poder chamá-los.

A Marcos Guilherme Cicarino Fantinato, pelas valorosas ponderações e pelo auxílio com a revisão ortográfica e gramatical dos originais.

A todos os que direta ou indiretamente contribuíram para a realização desta obra.

Aos meus familiares pelo amor inesgotável, confiança plena e apoio incondicional.

A Deus, por tudo. 
“Cidadania não combina com desigualdade. República não combina com preconceito. Democracia não combina com discriminação".

Min. Carmem Lúcia Antunes Rocha. (Ação Afirmativa. O conteúdo democrático do Princípio da Igualdade Jurídica. In: Revista de Informação Legislativa, 33, p. 33) 
RESUMO

O presente trabalho dedicou-se ao estudo de uma forma de discriminação que foge dos parâmetros usuais. As vítimas dessa nova forma de tratamento desigual não são integrantes de grupos historicamente desfavorecidos, como sói acontecer nas hipóteses mais usuais de discriminação, mas profissionais capacitados que investiram na sua formação profissional e acadêmica visando aumentar a sua empregabilidade. Investimento que, ao invés de facilitar o seu ingresso ou progresso no mercado de trabalho, como era esperado, tornou-se o motivo da sua preterição em contratações e promoções ou da sua dispensa. Esta conduta irregular, ora chamada discriminação por sobrequalificação, apresenta efeitos sociais perversos, pois desestimula o investimento em educação e em formação profissional, além de violar o direito ao desenvolvimento subjetivo de cada indivíduo. A sua gravidade se acentua ainda mais na medida em que vem se constatando que o número de ingressos em cursos universitários cresce mais do que o de postos de trabalho que demandam formação especializada criados, o que certamente fará com que um maior número de profissionais qualificados tenham que procurar empregos que não exijam os conhecimentos adquiridos.

Palavras-chave: Discriminação. Sobrequalificação. Igualdade. 
ABSTRACT

The present paper is aimed to the study of a way of discrimination different from the usual parameter. The victims of this new way of unequal treatment aren't part of the historically not endowed group, as it happens in the most common ways of discrimination, but capacitated professionals that have invested in their professional and academic formation seeking for work oportunits. Investiment that, instead of making the search for work easier, has became the reason for their preterition in contracts and promotions or the motive of their resignation. This irregular behavior, now called discrimination for overqualifiction, shows perverse social effects, once it discourage investiments in education and professional formation. Furthermore it violates each person's right to subjective development. It's gravity increases even more because it has been noticed that the number of new students in the universities is increasing more than the work opportunities that demands specialized formation. Due to this fact, it is certain that the number of qualified professionals that will have to search for jobs that don't demands their knowledge, will increase.

Key-words: Discrimination. Overqualification. Equality. 
1.Introdução . . . . . . . . . . . . . . . . . . . . . . . . . . . . . . . 12

2. Direitos Fundamentais. . . . . . . . . . . . . . . . . . . . . . 15

2.1 Denominação e aspectos históricos. . . . . . . . . . . . . . . 15

2.2. Dimensões dos direitos fundamentais. . . . . . . . . . . . . . . 22

2.3. Definição de direitos fundamentais. . . . . . . . . . . . . . . . . 26

2.4. Funções dos direitos fundamentais . . . . . . . . . . . . . . . . 27

3. Dignidade da pessoa humana. . . . . . . . . . . . . . . . . . . . . . . . 35

4. Princípio da igualdade. . . . . . . . . . . . . . . . . . . . . . . . . . . . 45

4.1. Evolução histórica do conceito de igualdade. . . . . . . . . . . . 45

4.2. Contraposição entre igualdade e liberdade. . . . . . . . . . . . . 56

4.3. Diferentes concepções de igualdade . . . . . . . . . . . . . . . 60

4.4. Princípio da igualdade, aplicação no direito do trabalho e eficácia 67 horizontal dos direitos fundamentais.

4.5. Princípio da igualdade e o legislador. . . . . . . . . . . . . 74

5. Direito ao desenvolvimento como direito fundamental. . . . . . . . . 78

5.1 Direito ao desenvolvimento no Brasil . . . . . . . . . . . . . . . . 86

5.2. Direito à educação . . . . . . . . . . . . . . . . . . . . . . . . . . . 87

5.3. Direito à formação profissional . . . . . . . . . . . . . . . . . . . . 94

5.4. Formação para acesso ao emprego e mecanismos de seleção laboral. . 100

5.5. Direito ao trabalho . . . . . . . . . . . . . . . . . . . . . 102

6. Discriminação . . . . . . . . . . . . . . . . . . . . . . . . . 105

6.1. Conceitos. . . . . . . . . . . . . . 106

6.2. Tipos de discriminação . . . . . . . . . . . . . . . . . . . . 111

6.3. Categorias de discriminação segundo o direito americano . . . . . . . 112

6.3.1. Tratamento diferenciado . . . . . . . . . . . . . . . . . . 114

6.3.2. Políticas ou práticas que se perpetuam na presença de efeitos de 116 
discriminações passadas.

6.3.3. Discriminação por impacto adverso . . . . . . . . . . . . . . 118

6.4. Momento da discriminação . . . . . . . . . . . . . . . . . . . 125

6.4.1. Discriminação na fase pré-contratual . . . . . . . . . . . . . . 125

6.4.2. Discriminação na fase contratual . . . . . . . . . . . . . . . 129

6.4.3. Discriminação por ocasião da rescisão do contrato de trabalho. . . . . 130

6.4.4.Combate à discriminação no direito internacional do trabalho . . . . . 130

6.4.5. Combate à discriminação no direito estrangeiro . . . . . . . . . . . 140

6.4.6. O combate à discriminação no direito brasileiro. . . . . . . . . . 151

6.4.7. Proteção jurisdicional contra a discriminação. . . . . . . . . . . 163

6.4.8. Negociação coletiva como instrumento de combate à discriminação. . 166

6.4.9. Ações afirmativas. . . . . . . . . . . . . . . . . . . . . 168

7. Discriminação por sobrequalificação . . . . . . . . . . . . . . . . 172

7.1. Discriminação por sobrequalificação na formação do contrato de trabalho 177

7.2. Discriminação por sobrequalificação na vigência do contrato de trabalho. 188

7.3. Discriminação por sobrequalificação no momento de extinção do contrato 190 de trabalho.

7.4. Conceito de discriminação por sobrequalificação. . . . . . . . . . 196

7.5. Tipos de discriminação por sobrequalificação. . . . . . . . . . . . 199

7.6. Efeitos da dispensa discriminatória em razão da sobrequalificação . . . 201

7.7. Efeitos da discriminação por sobrequalificação na formação e no curso do 203 contrato de trabalho.

7.8. O importante papel da negociação coletiva no combate à discriminação 208 por sobrequalificação .

7.9. ônus da prova nas ações relativas à discriminação por sobrequalificação . 210

7.10. Jurisdição metaindividual no combate à discriminação por 211 sobrequalificação.

8. Considerações Finais.

Referências Bibliográficas . . . . . . . . . . . . . . . . . . . . . 220

Anexos. . . . . . . . . . . . . . . . . . . . . . . . 233 


\section{1 - INTRODUÇÃO}

Durante muito tempo os estudos em matéria de direito do trabalho estiveram adstritos às questões patrimoniais, como se uma efetiva tutela aos empregados se desse apenas a partir da garantia do pagamento das parcelas salariais que lhes são asseguradas por lei. Esta situação vem se modificando nas últimas décadas na medida em que a tônica da tutela ao trabalhador tem, em quase todo o mundo, recaído também sobre temas relativos a direitos imateriais (ou, pelo menos, com efeitos patrimoniais apenas reflexos), tais quais o combate à discriminação, o respeito aos direitos humanos, o direito de sindicalização e a liberdade sindical. Houve, outrossim, uma mudança no enfoque depositado sobre a visão do trabalhador como contraparte da relação jurídica laboral.

Entre os temas que passaram a receber mais atenção dos estudiosos do direito do trabalho, merece grande destaque o do combate às condutas discriminatórias que violam o princípio da igualdade e ferem a dignidade da pessoa humana, e que, usualmente, são frutos de preconceitos decorrentes de estereótipos culturalmente estabelecidos. Veja-se, a título de exemplo, o expressivo número de documentos internacionais editados da segunda metade do século passado para cá e a crescente quantidade de obras abordando a questão publicadas nos últimos anos. As primeiras batalhas neste campo foram travadas para assegurar proteção aos chamados grupos desfavorecidos, mormente os negros e as mulheres. As primeiras normas legais sobre o assunto buscavam coibir condutas discriminatórias decorrentes de motivo de sexo, origem, raça e cor. Em um primeiro momento preocupava-se exclusivamente com a vedação ao tratamento discriminatório. Não havia cuidado com a adoção de medidas que assegurassem, mediante favorecimento jurídico, uma igualdade material. 
A partir da Segunda Grande Guerra Mundial e do grande número de inválidos por ela deixado, cresceu a preocupação com a discriminação de pessoas portadoras de deficiência.

Em período histórico próximo, passou-se a não se preocupar apenas em evitar o tratamento desigual, mas também em desenvolver mecanismos para, criando-se determinados favorecimentos jurídicos, assegurar igualdade material. Surgem assim as chamadas ações afirmativas ou discriminações positivas.

Neste início de milênio, contudo, apareceu, ou quiçá se tornou mais freqüente, uma forma de discriminação que foge um pouco dos parâmetros até então estudados. As vítimas dessa nova forma de tratamento desigual não são apenas os integrantes de grupos historicamente desfavorecidos, mas sim profissionais capacitados que investiram na sua formação profissional e acadêmica visando aumentar a sua empregabilidade. Este investimento, entretanto, ao invés de facilitar o seu ingresso ou progresso no mercado de trabalho, como era esperado, passa a ser justamente o motivo da sua preterição em contratações e promoções ou da sua dispensa. Esta odiosa conduta, ora chamada discriminação por sobrequalificação, apresenta efeitos sociais perversos, pois desestimula o investimento em educação e em formação profissional. Isto sem falar na ilicitude desta conduta que viola o direito ao desenvolvimento subjetivo de cada um, tema que também será objeto do presente estudo.

$\mathrm{Na}$ escolha do tema a ser estudado pesaram dois aspectos. Primeiro de tudo, a importância crescente do combate às práticas discriminatórias nas relações de trabalho, matéria que constitui hoje, indubitavelmente, um dos temas que mais atenção vem recebendo da doutrina e dos organismos internacionais e nacionais com atuação nesta área. Em segundo lugar, o fato de pouca atenção ser dada às ocorrências chamadas no presente trabalho de discriminação por sobrequalificação, não obstante estejam se tornando corriqueiras, por exemplo, notícias de universidades que despedem coletivamente professores tendo por critério de seleção justamente o maior grau de titulação, para em seguida substituí-los por outros menos titulados e, por conseguinte, menos onerosos aos seus cofres. A necessidade de melhor 
se estudar este fenômeno atual e preocupante justificou a pesquisa ora apresentada. Não se tem, todavia, a pretensão de, por meio dela, encontrar uma solução definitiva para a questão. Busca-se suscitar reflexões e exibir sugestões pessoais que possam contribuir para alertar a comunidade acadêmica sobre a relevância do tema.

Ao longo do desenvolvimento desta dissertação foram estudados, preliminarmente, os direitos fundamentais, em especial a sua gênese e aplicação nas relações particulares; o princípio da dignidade da pessoa humana e o da igualdade, a ele ligado; o direito ao desenvolvimento subjetivo em três de suas principais vertentes (o direito à educação, o direito à formação profissional, e o direito ao trabalho); e aspectos gerais sobre a discriminação nas relações de emprego, tais quais conceito, tipos, categorias de discriminação segundo a doutrina norte-americana, momentos em que pode ocorrer a discriminação, instrumentos disponíveis no direito brasileiro para combater esta prática e medidas que, se adotadas, poderiam ser implementadas para o êxito desta luta.

Feito isto, empreendeu-se uma análise da discriminação por sobrequalificação propriamente dita. Dedicou-se, então, atenção à sua caracterização; à possibilidade de ser ela verificada no momento de seleção de pessoal e formação do contrato de trabalho, ao longo do liame empregatício e por ocasião da rescisão contratual; e, por fim, aos mecanismos de combate a esta modalidade de discriminação. 


\section{DIREITOS FUNDAMENTAIS}

\subsection{DENOMINAÇÃO E ASPECTOS HISTÓRICOS}

O tema a ser desenvolvido insere-se inquestionavelmente dentro do conceito de direitos fundamentais, razão pela qual um estudo preliminar sobre tais direitos afigura-se indispensável para sua compreensão ${ }^{1}$. Sendo certo que ao longo dos anos diversas expressões como direitos do homem e do cidadão, direitos humanos, direitos naturais, direitos individuais, direitos subjetivos públicos (ou públicos subjetivos), liberdades públicas, liberdades fundamentais, direitos da personalidade foram utilizadas para designar este tema, o primeiro passo deste estudo consistirá em uma análise crítica sobre elas, estudando-as sob uma perspectiva histórica.

Cumpre ressaltar, logo de saída, que o legislador constituinte utilizou alternativamente vários destes termos. Falou em direitos sociais e individuais em seu preâmbulo; em direitos e deveres individuais e coletivos no Capítulo I do Título II; em direitos humanos nos artigos $4^{\circ}$, II, $5^{\circ}, \S 3^{\circ}$ e $7^{\circ}$ do ADCT; em direitos e liberdades fundametais no art. $5^{\circ}$, XLI; em direitos e garantias fundamentais na epigrafe do título II, e no artigo $5^{\circ}, \S 1^{\mathrm{o}}$; em direitos e liberdades constitucionais no artigo $5^{\circ}$, LXXI; e, finalmente, em direitos e garantias individuais no artigo 60, $\S 4^{\circ}$, IV. Além de apresentar importância do ponto de vista da precisão semântica, este estudo apresenta um significado conceitual, uma vez que parte da

\footnotetext{
${ }^{1}$ Hay consenso sobre el hecho de que la discriminación en el trabajo constituye una violación de un derecho humano que entraña un derroche de talento y efectos perjudiciales en la productividad y el crecimiento económico. (ORGANIZAÇÃO INTERNACIONAL DO TRABALHO (OIT). La igualdad en el trabajo: afrontar los retos que se plantean. Informe global con arreglo al seguimiento de la Declaración de la OIT relativa a los principios e derecho fundamentales relativos al trabajo. $96^{\mathrm{a}}$ Reunião Anual da Organização do Trabalho (OIT). Genebra, OIT, 2007, disponível em $<$ http://www.ilo.org.br/info/downloadfile.php?fileId=261> Acesso em: 22 de outubro de 2007, p. 25).
} 
doutrina tem estas palavras como sinônimas ou análogas ${ }^{2}$ e parte as tem com significados distintos.

A primeira das denominações referidas, direito do homem, é bastante antiga, remontando, segundo a maior parte da doutrina, à Idade Média. Há, contudo, autores, entre os quais cumpre nominar Jean Jacques Gandini, que entendem que a expressão não surgiu do espírito do homem ocidental moderno ${ }^{3}$, podendo ser identificada, já na antiguidade, entre os babilônios. Seja qual for o entendimento adotado, esta expressão mostra-se confusa por não ser possível, sem contradição, misturar as duas idéias: homem, no singular (a natureza genérica do homem), e a noção de direito ${ }^{4}$.

Gandini identifica ainda existir nas leis mosaicas, nas filosofias grega e chinesa e na doutrina cristã consagração dos direitos humanos, reconhecendo, todavia, que nestes casos se tratava mais de reflexões filosóficas frutos da revolta de uma parte da sociedade com a arbitrariedade do poder do que propriamente de textos fundadores de direto ${ }^{5}$. Ao final, reconhece que o texto legal

${ }^{2}$ Há uma corrente significativa de estudiosos que condena qualquer distinção entre os epítetos mencionados. Neste sentido Lucylla Tellez Merino asseverou: “(...) acreditamos que distinguir tais termos seria a negação das características essenciais dos Direitos Humanos, porque estes independem, como veremos a seguir, de qualquer positivação, e continuam fundamentais, porque sem a garantia desse rol o ser humano não encontra a vivência digna, por vezes apenas a sobrevivência ou, em linha indicativa, a negação da vida, que é a morte". MERINO, Lucyla Tellez. Direitos humanos e direito do trabalho: enfoques humanistas na proteção dos direitos sociais. 2006. 306 f. Dissertação (Mestrado em Direito). Faculdade de Direito. Universidade de São Paulo, São Paulo.

${ }^{3}$ Eu s'agita d'um Leung cheminement, un rapide e partiel survol historique nous permettant d'abord de remonter jusqu'à l'Antiquité. Nous en trouvons la première trace écrite connue dans le Code Hamourab en 1700 av J.-C à Babylone, l'écriture des lois pouvant d'ailleurs être considérée en soi comme une première conquête pour protéger l'individu contre l'arbitre du pouvoir. Ainsi Hammourabi voulait-il $<<$ faire éclater la justice pour empêcher e puissant de faire tour au faible $>>$. GANDINI, Jean-Jacques. Les droit de l'homme. Paris: Librio, 2004, p 5/6

${ }^{4}$ ROMITA, Arion Sayão. Direitos fundamentais nas relações de trabalho. São Paulo: LTr, 2005, p. 40.

${ }^{5} \mathrm{Au}$ XIIIe siècle av. J.-C, Moïse remet au peuple juif fuyant l'Égypte pour la Terre promise les $<<$ Tables de la Loi $>>$ directement dictées par Yahvé. Au Ve siècle av. J-C. l'Antigone de Sóphocle proclame la supériorité de la conscience individuelle de la loi humaine. Au siècle suivant, Platon recherche la justice et l'autorité, et Aristote l'équité. De son côté, Meng-Tseu écrit en 300 av. J-C que $<<$ l'individu est infiniment important, la personne du souverain est ce qu'il y a de moins important $>>$ et Siun-Tseu abord dans son sens au siècle suivant: $<<$ Qu'est-ce qui rend la société possible? Les droit de l'individu. $>>$ Séneque, au Ier siècle après J.-C., dans la lignée de l'école stoïcienne, affirme que $<<$ 'homme est une chose sacrée pour l'homme $>>$. Le christianism, lui, va privilegier la $<<$ créature humaine $>>$, sans exception ni distinction, au nom de la conscience individuelle, laquelle va être systématisée au Ve siècle par Augustin qui, en évoquant le concept de justice, ouvre virtuellement le droit à la contestation au nom de la liberté de conscience justement. Et le Coran affirme pour sa part que $<<$ l'être humain est la créature qui mérite un respect inconditionnel $>>$. GANDINI, Jean-Jacques. $O p$ cit, p. 6. 
precursor das futuras grandes declarações de direitos do homem surge efetivamente na Idade Média. Trata-se da Magna Carta redigida na França por emigrantes ingleses revoltados com seu rei João Sem Terra ${ }^{6}$. Este movimento se perpetua na Inglaterra com a Petition des Droits de 1628, institucionalizada em 1679 com o Habeas Corpus $^{7}$ e a Bill of Rights ${ }^{8}$, que proclama as bases da Constituição Inglesa e consagra a vitória sobre o absolutismo dos Stuarts, definindo os direitos do Parlamento e dos cidadãos. Em seguida, ainda na Idade Moderna, atravessa o Atlântico e o Canal da Mancha, consagrando-se também na América por meio da Virginia Bill of Rights e da Declaração de Independência ${ }^{9}$, ambas no ano 1776, e na França, por intermédio da Declaration des Droits de l'Homme et du Citoyen de 1789.

Quanto à Declaração dos Direitos do Homem e do Cidadão de 1789, cumpre destacar dois pontos. Em primeiro lugar, ela não apresentava nenhum valor normativo por ocasião de sua proclamação, situação que perdurou até a sua reafirmação solene no Preâmbulo da Constituição Francesa de 27 de outubro de

${ }^{6}$ GANDINI, Jean-Jacques. Op cit. p. 6. Segundo Fábio Konder Comparato, “As disposições da Magna Carta regulam várias matérias e nem todas elas podem ser tidas como importantes, na evolução histórica tendente à progressiva afirmação dos direitos humanos e à instituição do regime democrático. Há, assim, disposições de sentido puramente local ou conjuntural, ao lado de outras que constituem as primeiras fundações da civilização moderna”. (Ibidem, p. 79).

${ }^{7}$ Para Fábio Konder Comparato, “O habeas-corpus já existia na Inglaterra, desde há vários séculos (mesmo antes da Magna Carta), como mandado judicial (Writ) em caso de prisão arbitrária. Mas a sua eficácia como remédio jurídico era muito reduzida, em razão da inexistência de adequadas regras processuais. A Lei de 1679, cuja denominação oficial foi "uma lei para melhor garantir a liberdade do súdito e para prevenção das prisões de ultramar", veio corrigir esse defeito e confirmar no povo inglês a verdade do brocardo remedies precede rights, isto é, são as garantias processuais que criam os direitos e não o contrário (COMPARATO, Fábio Konder. A afirmação histórica dos direitos humanos. São Paulo: Saraiva, 2001, p. 85). E adiante aduziu que "A importância histórica do habeas-corpus, tal como regulado pela lei inglesa de 1679 , consistiu no fato de que essa garantia judicial, criada para proteger a liberdade de locomoção tornou-se a matriz de todas as que vieram a ser criadas posteriormente, para a proteção e outras liberdades fundamentais" (Ibidem, p. 86).

${ }^{8}$ De acordo com Comparato, "o Bill of rights criava com a divisão de poderes, aquilo que a doutrina constitucionalista alemã do século XX viria denominar, sugestivamente, uma garantia institucional, isto é, uma forma de organização do Estado cuja função, em última análise, é proteger os direitos fundamentais da pessoa humana" (Op. Cit. p. 90/91). Demais disso, referido autor destaca que "o Bill of Rights veio fortalecer a instituição do júri e reafirmar alguns direitos fundamentais dos cidadãos, os quais são expressos até hoje, nos mesmos termos, pelas Constituições modernas, como o direito de petição e a proibição de penas inusitadas e cruéis" (Ibidem, p. 93).

${ }^{9}$ Segundo Fábio Konder Comparato, “A independência das antigas treze colônias britânicas da América do Norte, em 1776, reunidas primeiro sob a forma de uma confederação e constituídas em seguida em Estado federal, em 1787, representou o ato inaugural da democracia moderna, combinando, sob o regime constitucional, a representação popular com a limitação de poderes governamentais e o respeito aos direitos humanos" (op cit, p. 95). Em suas lições, "A importância histórica da Declaração de Independência reside no fato de ter sido "o primeiro documento político que reconhece, a par da legitimidade da soberania popular, a existência de direitos inerentes a todo ser humano, independentemente das diferenças de sexo, raça, religião, cultura ou posição social'(ibidem, p. 103). 
1946, quando adquiriu um valor constitucional ${ }^{10}$. Em segundo lugar, ela estabelecia a distinção entre os direitos do homem vistos em caráter universal, abstrato, e os direitos do cidadão, pois somente este gozaria de direitos perante o Estado ${ }^{11}$. Ainda assim não se pode minorar a sua importância histórica para o efetivo assentamento dos direitos humanos no curso da história ${ }^{12}$.

\section{José Afonso da Silva observa haver objeções contra} esta terminologia pautadas, sobretudo, na constatação de que não há direito que não seja humano ou do homem, na medida em que só o ser humano pode ser titular de direitos ${ }^{13}$.

A expressão direito natural, por sua vez, encontrava justificativa na circunstância de serem eles pré-estatais, inatos, inerentes à natureza humana. Segundo Ingo Wolfgang Sarlet, a consideração de que o termo "direitos humanos" pode ser equiparado ao epíteto "direitos naturais" não é correta em razão da sua própria positivação em normas de direito internacional já revelar de forma incontestável a dimensão história e relativa dos direitos humanos, que assim se desprenderam da idéia de um direito natural ${ }^{14}$. José Afonso da Silva, por sua vez,

${ }^{10}$ N'ayant aucune valeur normative lors de sa proclamation, la Déclaration de 1789 será reaffirmé solennellement dans le Préambule de la Constitution du 27 octobre 1946, lui conférant ainsi une valeur constitutionelle. (GANDINI, Jean-Jacques. Op cit. p. 8)

${ }^{11}$ ROMITA, Arion Sayão, Op Cit. p. 40

${ }^{12}$ É o que denota a seguinte lição de Fábio Konder Comparato: "Seja como for, as ondas de revolta provocadas pela Revolução de 1789, não só na França, como em toda a Europa Ocidental e em outros continentes, desmentem a tese segundo a qual as declarações francesas, por serem meras exortações, teriam sido menos importantes que os bills of rights norte-americanos, para o efetivo assentamento dos direitos humanos no curso da história. Como foi salientado em outra parte, as técnicas jurídicas utilizadas, em um e outro caso, são bem diferentes. Seguindo a tradição inglesa, os norte-americanos deram mais ênfase às garantias judiciais do que à declaração de direitos pura e simples. Os franceses, ao contrário, quase que se limitaram à declarar direitos, sem mencionar os instrumentos judiciais que os garantissem. É preciso não esquecer, no entanto, que o Direito vive, em última análise, na consciência humana. Não é porque certos direitos subjetivos estão desacompanhados de instrumentos assecuratórios próprios que eles deixam de ser sentidos no meio social como exigências impostergáveis. Aliás, ninguém mais nega, hoje, que a vigência dos direitos humanos independe do seu reconhecimento constitucional, ou seja de sua consagração no direito positivo estatal como direitos fundamentais (Grundrechte, segundo a terminologia alemã). Por isso mesmo, uma proclamação de direitos, mesmo quando despida de garantias efetivas de seu cumprimento, pode exercer, conforme o momento histórico em que é lançada, o efeito de um ato esclarecedor, iluminando a consciência jurídica universal e instaurando a era da maioridade histórica do homem" (Comparato, op. cet., pp. 135/136.).

${ }^{13} \mathrm{O}$ referido autor alerta, todavia, que talvez já não seja mais assim, porque aos poucos vai se formando um direito especial de proteção dos animais. SILVA, José Afonso. Comentário contextual à Constituição. São Paulo: Malheiros, 2005 p. 55.

${ }^{14}$ SARLET, Ingo Wolfgang. A eficácia dos direitos fundamentais. Porto Alegre, Livraria do Advogado, 2003, p. 34. O autor pondera, contudo, que não se pode esquecer que, na sua vertente histórica, os direitos humanos (internacionais) e fundamentais (constitucionais) radicam no reconhecimento, pelo 
pondera que "não se aceita mais com tanta facilidade a tese de que tais direitos sejam naturais, provenientes da razão humana ou da natureza das coisas ${ }^{15}$.

As expressões liberdades públicas e liberdades fundamentais mereceram críticas do constitucionalista Ivo Wolfgang Sarlet ${ }^{16}$. Segundo ele, a moderna teoria do direito constitucional, ressalvadas algumas exceções, vem rechaçando progressivamente a utilização destes termos e de outros como "direitos individuais" e "direitos púbicos subjetivos", "direitos naturais", "direitos civis", assim como as suas variações, porquanto - ou menos como termos genéricos - anacrônicos e, de certa forma, divorciados do estágio atual da evolução dos direitos fundamentais no âmbito de um Estado (democrático e social) de Direito, até mesmo em nível do direito internacional, além de revelarem, com maior ou menor intensidade, uma flagrante insuficiência no que concerne à sua abrangência, visto que atrelados a categorias específicas do gênero direitos fundamentais ${ }^{17}$.

Fato é que a expressão Direitos Fundamentais restou consagrada. Segundo Edílson Pereira Nobre Júnior, é possível se notar, a partir da Constituição alemã de 1919, uma preferência pelo uso do binômio direitos fundamentais em detrimento do enunciado direitos do homem, em razão deste evocar apenas os direitos derivados da natureza humana; e, em detrimento do epíteto direitos da personalidade, por este abarcar um pequeno círculo de direitos subjetivos, restritos ao estado da pessoa e aos direitos sobre a própria pessoa, tais como o direito à vida, à integridade física e moral, ficando excluídos os direitos políticos e sociais. A preponderância da utilização da expressão direitos fundamentais sobre a denominação direitos individuais, por outro lado, deve-se ao fato desta espelhar apenas os direitos subjetivos consagrados pelo ideário liberal. Por fim, o referido autor destaca ser o termo em questão mais adequado do que direitos políticos, cujo universo é restrito às manifestações tradicionais da cidadania ativa (direito de escolher os representantes

direito positivo, de uma série de direitos naturais do homem, que, neste sentido, assumem uma dimensão pré-estatal e, para alguns, até mesmo supra-estatal. Ademais, cuida-se, sem dúvida, igualmente de direitos humanos - considerados como tais àqueles outorgados a todos os homens pela sua mera condição humana -, mas, neste caso, de direitos não positivados.

${ }^{15}$ SILVA, José Afonso. Comentário contextual à constituição. São Paulo: Malheiros, 2005 p. 55.

${ }^{16}$ SARLET, Ivo Wolfgang. A eficácia..op. cit.. 3a edição. Porto Alegre, 2003, p. 33.

${ }^{17}$ SARLET, Ivo Wolfgang. Ibidem. 
populares no Executivo e no Legislativo) e passiva (prerrogativa de ser eleito para os cargos de direção superior do Estado) ${ }^{18}$.

Isto não significa, porém, que outras expressões não sejam também utilizadas. Hoje, por exemplo, costuma-se fazer uso da expressão direitos humanos com conotação diversa da dos direitos fundamentais, apesar de, como pondera Ingo Sarlet, não haver dúvidas de que os direitos fundamentais, de certa forma, são também sempre direitos humanos, no sentido de que seu titular sempre será o ser humano, ainda que representado por entes coletivos (grupos, povos, nações, Estado) ${ }^{19}$. Fala-se em direitos fundamentais ao se tratar daqueles direitos do ser humano reconhecidos e positivados na esfera do direito constitucional de determinado Estado, e em direitos humanos para os consagrados em documentos de direito internacional, por referir-se àquelas posições jurídicas que se reconhecem ao ser humano como tal, independentemente de sua vinculação com determinada ordem constitucional, que, portanto, aspiram à validade universal, para todos os povos e tempos, de tal sorte que revelam um inequívoco caráter supranacional (internacional) ${ }^{20}$.

O mesmo doutrinador ainda cuida de fazer, para fins meramente didáticos, uma distinção dos dois epítetos acima em relação à expressão direitos do homem. Para ele, "direitos do homem" seriam aqueles naturais, ou ainda não positivados; "direitos humanos", os positivados na esfera do direito internacional; e "direitos fundamentais", aqueles reconhecidos ou outorgados e protegidos pelo direito constitucional interno de cada Estado ${ }^{21}$.

Essa distinção entre direitos humanos e direitos fundamentais, contudo, não recebeu aplausos de toda a doutrina. Uma das críticas mais contundentes, entre as que lhe são dirigidas, é a que parte da constatação de que o fato

\footnotetext{
${ }^{18}$ NOBRE JÚNIOR, Edílson Pereira. Direitos fundamentais e argüição de descumprimento de preceito fundamental. Porto Alegre, Sérgio Antonio Fabris, 2004, pp. 13/14.

${ }^{19}$ SARLET. Ingo Wolfgang. A eficácia...op. cit. p. 33.

${ }^{20}$ SARLET, Ingo Wolfgang. A eficácia...Op cit. p. 33.

${ }^{21}$ SARLET, Ingo Wolfgang. A eficácia...Op. cit. p. 34. Segundo Fábio Konder Comparato esta distinção teria sua gênese na doutrina jurídica germânica É aí que se põe a distinção, elaborada pela doutrina jurídica germânica, entre direitos humanos e direitos fundamentais (Grundrechte). Estes últimos são os direitos humanos reconhecidos como tal pelas autoridades, às quais se atribui o poder político de editar normas, tanto no interior dos Estados quanto no plano internacional; são os direitos positivados nas Constituições, nas leis, nos tratados internacionais (COMPARATO, Fábio Konder. Op cit, p. 56).
} 
de um "direito humano" ser constitucionalmente consagrado não o torna mais fundamental do que um que não o seja. Sobretudo pela existência de países que não possuem a tradição de elaborar um rol de direitos desta natureza em sua carta constitucional.

Fábio Konder Comparato ressalta a necessidade de se buscar um fundamento mais profundo para os direitos humanos e para os direitos fundamentais, uma vez que "nada assegura que falsos direitos humanos, isto é, certos privilégios da minoria dominante, não sejam também inseridos na Constituição, ou consagrados em convenção internacional, sob a denominação de direitos fundamentais $^{22 " \text {. }}$

Tratando diretamente do direito brasileiro positivado, há de se destacar que a Constituição Federal de 1988 faz uso das expressões direito fundamental, direito individual e garantia fundamental, distinguindo-as. Manoel Jorge e Silva Neto assevera que a Constituição de 1988 trata direito fundamental como o gênero dentro do qual podem ser inseridos os direitos individuais propriamente ditos, os direitos sociais, os direitos da nacionalidade e os direitos políticos e partidos políticos, o que restaria evidenciado no fato de seu título II iniciar com a epígrafe 'Dos Direitos e Garantias Fundamentais', relacionando, nos arts. $5^{\circ}$ a 17 , as referidas categorias. Referido autor destaca ainda não ser possível a identificação dos direitos fundamentais com as garantias fundamentais na medida em que estas se convertem, ofuscantemente, em instrumentos à efetivação dos direitos individuais, sociais, da nacionalidade e políticos ${ }^{23}$.

Há que se ressaltar, contudo, que após a Emenda Constitucional n. 45 a distinção entre direitos fundamentais e direitos humanos perdeu força. A explicação é simples. Ao possibilitar expressamente que os tratados e convenções internacionais adquiram força de Emenda Constitucional quando aprovados, em cada Casa do Congresso Nacional, em dois turnos, por três quintos dos votos dos respectivos membros, o legislador constituinte derivado permitiu

\footnotetext{
${ }^{22}$ Ibid. p. 56.

${ }^{23}$ SILVA NETO, Manoel Jorge e. Direitos fundamentais e contrato de trabalho. São Paulo: LTr, 2005, p. 13.
} 
textualmente que se convertessem normas de direitos humanos em normas de direitos fundamentais. Essa possibilidade serve, por si só, para demonstrar não haver diferença ontológica entre elas, o que torna desnecessária a distinção doutrinária. Por esta razão, utilizar-se-ão, para os fins do presente estudo, as expressões direitos fundamentais e direitos humanos indistintamente, tendo-as como as parcelas de direitos, positivados ou não, consagrados internacionalmente ou em um país próprio, inerentes a todo ser humano.

\subsection{DIMENSÕES DOS DIREITOS FUNDAMENTAIS.}

A doutrina constitucionalista clássica costuma classificar os direitos fundamentais em gerações, expressão que se tornou alvo de inúmeras críticas. A principal delas consistiria justamente na equivocada idéia de sucessividade de uma geração pela outra que ela transmite ${ }^{24}$. Atento a estas observações, Edílson Pereira Nobre Júnior assevera que a sobrevinda de outra geração de direitos acarreta a necessidade de harmonização dos diversos direitos. E exemplifica observando que o direito de propriedade, típico direito de primeira geração, não foi eliminado pela posterior positivação da função social da propriedade, o que tornou indispensável uma harmonização entre ambos ${ }^{25}$.

Outra crítica dirigida a esta classificação fundamentase na diferença existente entre a evolução da sucessão geracional no direito internacional e no direito interno dos diversos países. Isto porque, como salienta Antônio Augusto Cançado Trindade, tudo indica haver certo descompasso entre a evolução da matéria no direito internacional e no direito interno. Justifica sua assertiva

${ }^{24}$ Bastante pertinentes a este respeito são as lições de Antônio Augusto Cançado Trindade: "Entre as distintas 'categorias' de direitos - individuais e sociais ou coletivos - só pode haver complementaridade e não antinomia, o que revela a artificialidade da noção simplista da chamada 'terceira geração' de direitos humanos: os chamados direitos de solidariedade, historicamente mais recentes, em nosso entender, interagem com os direitos individuais e sociais, e não os 'substituem', distintamente do que a invocação inadequada da imagem do suceder das gerações pareceria insinuar". (TRINDADE, Antônio Augusto Cançado. A proteção internacional dos direitos humanos: fundamentos jurídicos e instrumentos básicos. São Paulo: Saraiva, 1991, p.41) 
asseverando que enquanto no direito interno (constitucional) o reconhecimento dos direito sociais foi historicamente posterior ao dos direitos civis e políticos, no plano internacional ocorreu o contrário. Exemplo disso seria o fato de muitas das sucessivas e numerosas convenções internacionais do trabalho, editadas a partir do estabelecimento da OIT em 1919, haverem precedido a adoção de convenções internacionais mais recentes voltadas aos direitos civis e políticos ${ }^{26}$.

Dimitri Dimoulis e Leonardo Martins tecem uma outra crítica. Em sua opinião, o "termo geração" não é cronologicamente exato, na medida em que é possível indicar que já havia direitos sociais (prestações do Estado) garantidos nas primeiras Constituições e Declarações do século XVIII e de inícios do século XIX. Exemplificam, destacando que a Declaração Francesa, de 1793, garantia a assistência aos necessitados como uma "dívida sagrada" da sociedade e o direito de acesso à educação; e a Constituição brasileira do Império, de 1824, incluía entre os direitos fundamentais dois direitos sociais, os socorros públicos e a instrução primária gratuita. $^{27}$

Por estas razões optou-se, no presente trabalho, por utilizar o epíteto "dimensões" em detrimento de "gerações" dos direitos fundamentais, acompanhando assim uma tendência verificada em obras doutrinárias recentes ${ }^{28}$, muito embora alguns dos autores citados utilizem ainda este último termo.

Os direitos humanos de primeira dimensão, tais quais os consagrados na Declaração de Virgínia e na Declaração Francesa de 1789, caracterizam-se por encontrarem alicerce na clara demarcação entre Estado e não-

\footnotetext{
${ }^{25}$ NOBRE JÚNIOR, Edílson Pereira. Direitos fundamentais...op. cet., p. 22.

${ }^{26}$ Ibidem, p.22.

${ }^{27}$ DIMOULIS, Dimitri e MARTINS, Leonardo. Teoria geral dos direitos fundamentais. São Paulo: RT, 2007, p. 35. Ingo Wolfgang Sarlet também destaca que alguns direitos de liberdade por intermédio do Estado já estavam consagrados de forma embrionária e isolada nas Constituições Francesas de 1793 e 1848, na Constituição Brasileira de 1824 e na Constituição Alemã de 1849 (que não chegou a entrar efetivamente em vigor) (A eficácia...op cet, p. 52).

${ }^{28}$ Optam por esta terminologia entre outros André Ramos Tavares (TAVARES, André Ramos. Curso de direito constitucional. $5^{\text {a }}$ edição. São Paulo: Saraiva, 2007, p. 426), Ingo Wolfgang Sarlet (SARLET, Ingo Wolfgang. A eficácia dos direitos fundamentais. $3^{a}$ edição. Porto Alegre: Livraria do Advogado Editora, 2003, p. 50). O termo "dimensões", contudo, também não restou indene de críticas. Segundo Dimitri Dimoulis e Leonardo Martins utiliza-se o epíteto "dimensão" para indicar dois ou mais componentes ou aspectos do mesmo fenômeno ou elemento e há grupos de direitos fundamentais cuja finalidade e funcionamento são claramente diferenciados em âmbito jurídico (op cit, p. 35).
} 
Estado, fundada no contratualismo de inspiração individualista. Segundo Celso Lafer, esses direitos são considerados individuais quanto ao modo de exercício, já que é individualmente que se afirma, por exemplo, a liberdade de opinião; quanto ao sujeito passivo do direito, uma vez que o titular do direito individual pode afirmá-lo em relação a todos os demais indivíduos, já que estes direitos têm como limite o reconhecimento do direito do outro e quanto seu ao titular que é o homem em sua individualidade ${ }^{29}$. Segundo Ingo Wolfgang Sarlet, “assumem particular relevo no rol desses direitos, especialmente pela sua notória inspiração jusnaturalista, os direitos à vida, à liberdade, à propriedade e à igualdade perante a lei" ${ }^{\text {30 }}$.

Retomando a opinião de Celso Lafer, a evolução do liberalismo e individualismo - ideologias predominantes na primeira geração de direitos humanos -, ver-se-ia complementada pelo reconhecimento, não contemplado na Declaração de 1789, de direitos individuais exercidos coletivamente, e, posteriormente, pelo legado do socialismo, as reivindicações dos desprivilegiados a um direito de participar do "bem-estar-social"31. Surgem, assim, os chamados direitos humanos de segunda dimensão, tais quais o direito ao trabalho, à saúde, à educação, os quais têm como sujeito passivo o Estado porque, na interação entre governantes e governados, foi a coletividade quem assumiu a responsabilidade de atendê-los. Todavia, embora o sujeito passivo seja o Estado, o titular desse direito continua sendo, como nos direitos de primeira dimensão, o homem na sua individualidade, o que demonstra a complementaridade existente entre eles.

Como salienta Celso Lafer, os direitos de segunda dimensão buscam assegurar as condições para o pleno exercício dos direitos de primeira, eliminando ou atenuado os impedimentos ao pleno uso das capacidades humanas $^{32}$. O mesmo autor destaca que o reconhecimento dos direitos de segunda dimensão deu-se ainda no crepúsculo do século XVIII ${ }^{33}$.

\footnotetext{
${ }^{29}$ LAFER, Celso. A reconstrução dos direitos humanos: um diálogo com o pensamento de Hanna Arendt. São Paulo: Compahia das Letras, 1988, pp. 126/127

${ }^{30}$ SARLET, A eficácia...op cit, p. 51/52.

${ }^{31}$ LAFER, op. cit. p. 127.

${ }^{32}$ Ibidem, p. 127.

33 Em suas palavras: "No plano do Direito Positivo o reconhecimento da importância dos direitos de segunda geração já se encontra na Constituição Francesa de 1791, que no seu Título $1^{\circ}$, previa a instituição do secours publicis para criar crianças abandonadas, aliviar os pobres doentes e dar trabalho aos pobres inválidos que não o encontrassem. Na Constituição Francesa de 1848, que apesar de ter
} 
Lafer pondera ainda que dentro de uma perspectiva $e x$ parte populi, que é a da liberdade, haveria uma pequena contradição no exercício dos direitos destas duas dimensões, haja vista os da primeira almejarem limitar os poderes do Estado, demarcando com nitidez a fronteira entre Estado e sociedade, e os da segunda geração exigirem a ampliação dos poderes do Estado ${ }^{34}$.

Os direitos reconhecidos como do homem na sua singularidade - sejam eles os de primeira ou de segunda geração - têm uma titularidade inequívoca: o indivíduo. Entretanto, na passagem de uma titularidade individual para uma coletiva, que caracteriza os direitos de terceira e quarta dimensão, podem surgir dilemas no relacionamento entre o indivíduo e a coletividade que exacerbam a contradição em vez de afirmar a complementaridade do todo e da parte. Estes dilemas, segundo Celso Lafer, adviriam sobretudo da multiplicidade infinita dos grupos que podem sobrepor-se uns aos outros, o que traz uma difusa e potencial imprecisão em matéria de titularidade coletiva ${ }^{35}$.

Já os chamados direitos fundamentais de terceira dimensão, chamados direitos de solidariedade ou fraternidade, englobam o direito a um meio ambiente equilibrado, uma saudável qualidade de vida, ao progresso, à paz, à autodeterminação dos povos e a outros direitos difusos ${ }^{36}$. Tais direitos caracterizam-se e distinguem-se dos demais porque seus titulares não são indivíduos ou grupos específicos de pessoas. Como salienta Paulo Afonso Linhares, são interesses que dizem respeito, em derradeira análise, à própria humanidade ${ }^{37}$.

emanado de uma Constituinte conservadora, refletiu a consciência dos problemas trazidos pela Revolução Industrial e pela condição operária, o tema aparece no item I do Preâmbulo, no trecho que considera como objetivo da República o de 'assurer une répartition de plus en plus équitable des charges e des avantages de la societé'. Nesta Constituição, no entanto, se já há o reconhecimento de deveres sociais do Estado, não existe uma proclamação dos direitos correlativos dos cidadãos. Estes só surgirão nos textos constitucionais no século XX, por força da influência da Revolução Russa, da Revolução Mexicana e da Constituição de Weimar. Na realidade brasileira, como é sabido, o reconhecimento constitucional dos direitos de segunda geração data da Constituição de 1934"(Ibidem, p. 128).

${ }^{34}$ Ibidem, p. 129.

${ }^{35}$ Ibidem, p. 132.

${ }^{36}$ MORAES, Alexandre de. Direito constitucional. 15a edição. São Paulo: Atlas, 2004, p. 62.

${ }^{37}$ LINHARES, Paulo Afonso. Direitos fundamentais e qualidade de vida. São Paulo: Iglu, 2002, p. 52. 
Vários doutrinadores vêm, em tempos recentes, cogitando uma quarta dimensão de direitos, relacionada com os efeitos da evolução da pesquisa científica e biológica (clonagem, alimentos transgênicos, etc.), e cujo escopo seria ditar parâmetros de controle que amenizem o instinto de ganho e proveito por parte de indivíduos e grupos desprovidos de escrúpulos.

\subsection{DEFINIÇÃO DE DIREITOS FUNDAMENTAIS.}

Como salienta Abdelfattah Amor, etimologicamente, chama-se de fundamental aquilo que serve de base, de fundamento. Em outras palavras, fundamental é aquilo sobre o qual se apóia todo o resto ${ }^{38}$. Desta forma, falase em fundamentos do Estado, da sociedade, de uma doutrina, etc. Invocar o fundamental equivale então a buscar a origem, o ponto de partida, o alicerce que sustenta o conjunto do edifício ${ }^{39}$.

Os chamados direitos fundamentais podem ser visto sob duas grandes perspectivas: formal e material. Segundo a primeira, reputa-se fundamental todo direito das pessoas objeto de consagração no texto da Lei Maior ${ }^{40}$. De acordo com a segunda, se insere no conceito de direitos fundamentais também os direitos resultantes da concepção de Direito e do sentimento jurídico coletivo ${ }^{41}$. Em outras palavras, para esta última corrente a fundamentalidade de certos direitos não dependeria da força formal constitucional e sim de seu conteúdo.

Não há, contudo, como concordar com esta definição mais ampla. Explica-se: ao se considerar como fundamental um direito criado pelo

\footnotetext{
38 "Étymnologiquement, ce qui est fondamental, c'ést ce qui sert de base, de fondement. En d'autres termes ce qui est fondamental, c'est ce qui est essentiel et sur lequel s'appuie tout le reste". AMOR, Abdelfattah. Rapport Introductif. In Les droits fondamentaux: universalité et diversité; Droit au développement; Démocratie et État de Droit; Commerces illicites. Bruxelles: Emile Bruylant: 1997, pp. $31 / 40$ ).

${ }^{39}$ Ibidem, p. 31.

${ }^{40}$ NOBRE JÚNIOR, Edilson Pereira. Direitos fundamentais...p cit, p. 11.

${ }^{41}$ Ibidem, p. 11.
} 
legislador ordinário, admite-se que se incluam nestas categorias direitos revogáveis na primeira mudança da maioria parlamentar, o que confere à categoria um ar de potencial transitoriedade incompatível com a idéia que se quer passar. Não fosse isto o bastante, há que se destacar, com amparo no magistério de Edílson Pereira Nobre Júnior, que a expressão direitos fundamentais visa legar significado ao conjunto dos direitos subjetivos que se encontram consagrados na constituição ${ }^{42}$. Ora, se a finalidade do instituto é conferir significado a direitos consagrados na Carta Magna, não parece razoável ampliar o seu conteúdo para incluir direitos consagrados na legislação infraconstitucional.

Dito isto, pode-se concluir que direitos fundamentais são direitos público-subjetivos, formalmente inseridos em dispositivos constitucionais, que apresentam um caráter normativo supremo dentro do Estado.

\subsection{FUNÇÕES DOS DIREITOS FUNDAMENTAIS.}

Os autores que se dedicaram ao estudo dos direitos fundamentais destacam a sua dupla função (também chamada dupla dimensão, dupla natureza ou duplo caráter). Como salienta André Rufino do Vale, em primeira linha, os direitos fundamentais visam à satisfação de interesses próprios dos titulares, conferindo aos cidadãos pretensões a que sejam realizadas ações ou omissões tendentes a assegurar os valores e bens constitucionais que lhes são concedidas pelas normas constitucionais $^{43}$. Tem-se, assim, a chamada dimensão subjetiva dos direitos fundamentais, cujo papel é justamente delimitar as posições jurídicas dos seus titulares em face do Estado.

A dimensão objetiva por sua vez, "traduz-se na fundamentação dos direitos fundamentais como valores, regras ou princípios

\footnotetext{
${ }^{42}$ NOBRE JÚNIOR, Edílson Pereira. Direitos fundamentais...op. cit., p. 11.

${ }^{43}$ VALE, André Rufino do. Eficácia dos direitos fundamentais nas relações privadas. Porto Alegre: Sergio Antonio Fabris Ed., 2004, p. 78.
} 
possuidores de validez objetiva, absoluta e universal, independentemente da experiência dos indivíduos" ${ }^{44}$. De acordo com essa dimensão, cada norma de direitos fundamentais corresponderá a um dever objetivo, o que faz com que eles, nesse sentido, representem princípios que irradiam por todo o ordenamento jurídico, influenciando em todos os seus âmbitos ${ }^{45}$. É justamente desse poder de irradiação das normas de direitos fundamentais por todo o ordenamento jurídico que decorrerá a sua eficácia também nas relações entre particulares, defendida neste trabalho especialmente em relação ao princípio da igualdade e seus corolários.

Essa dimensão objetiva, contudo, segundo entendimento majoritário, é posterior à subjetiva, tendo surgido com o Estado Social e seu modelo de concepção dos direitos fundamentais como princípios da ordem jurídica $^{46}$. A sua concepção atual deve-se, sobretudo, à chamada teoria da eficácia frente a terceiros ou da eficácia horizontal dos direitos fundamentais (Drittwirkung der Grundrechte), desenvolvida na Alemanha por Hans Carl Nipperdey em 1954 e, posteriormente, aceita pela jurisprudência do Tribunal Federal do Trabalho e do Tribunal Constitucional daquele país, sobre a qual oportunamente serão tecidos maiores comentários ${ }^{47}$. Segundo essa doutrina, não é apenas o Estado quem pode exercer um poder capaz de ameaçar os direitos fundamentais das pessoas, mas também os mesmos sujeitos ou organizações criadas pelo direito privado ${ }^{48}$.

Virgílio Afonso da Silva destaca, entretanto, que, a despeito de seu grande comprometimento com o Estado social, a dificuldade de lidar com os efeitos horizontais dos direitos fundamentais foi enorme na Alemanha, em

\footnotetext{
${ }^{44}$ Ibidem, p. 78.

${ }^{45}$ Ibidem, p. 78.

${ }^{46}$ Ibidem, p. 79.

${ }^{47}$ ROJO, Eduardo Caamaño. El derecho a la no discriminación en el empleo. Santiago: LexisNexis, 2005 , p. 14. Segundo Virgílio Afonso da Silva, na Alemanha, "desde o famoso caso Lüth (BVerfGE 7, 1998), no qual se reconheceu que - embora os direitos fundamentais sejam, em primeira linha, direitos de defesa do cidadão contra o Estado -, seus efeitos não se limitam a esse tipo de relação, discute-se de que forma esses direitos podem - ou devem - interferir na autonomia privada. Discute-se, nesse âmbito, sobretudo acerca dos efeitos diretos ou indiretos daqueles no âmbito desta" (SILVA, Virgílio Afonso da. A constitucionalização do direito: os direitos fundamentais nas relações entre particulares. São Paulo, Malheiros, 2005, p. 21). Em outra passagem esclarece aduzindo que na referida decisão "o tribunal, embora conceba que os direitos fundamentais sejam, em primeira linha, direitos de defesa dos cidadãos contra o Estado, desenvolve uma função complementar que, durante décadas, suscitou as maiores controvérsias no âmbito da dogmática dos direitos fundamentais (Ibidem, p. 42).

${ }^{48}$ ROJO, Eduardo Caamaño. Op. cit., p. 15.
} 
decorrência, sobretudo, de um problema normativo-constitucional: a ausência de normas de direitos fundamentais que não aquelas de cunho liberal ${ }^{49}$.

Nos Estados Unidos da América, a temática acerca da irradiação dos efeitos dos direitos fundamentais nas relações entre particulares passou a ser objeto de estudos a partir da decisão da Suprema Corte no caso Shelley v. Kramer $^{50}$, demanda em que se discutia a validade de cláusula contratual exigindo que os compradores de terrenos em um loteamento na cidade de Saint Louis não os alienassem em favor de indivíduos não-brancos. Curiosamente a ação não foi proposta por um negro ou por grupos defensores de minorias étnicas e raciais contra esta exigência flagrantemente discriminatória, o que hoje seria mais fácil de admitir. Mas, por vizinhos que resolveram contestar o fato de um dos proprietários haver decidido vender sua propriedade a um casal de negros, alegando ter havido violação de cláusula restritiva. O Tribunal Estadual de Missouri acolheu o pedido, mas teve sua decisão reformada pela Suprema Corte, que entendeu que aquela cláusula restritiva feria a cláusula da igualdade da Emenda XIV.

Portugal e Argentina possuem preceitos constitucionais expressos facultando aos particulares nas suas relações socorrerem-se das normas constitucionais que vinculam os atos dos entes sujeitos aos direitos fundamentais. Com efeito, o artigo $18^{\circ}, 1$ da Constituição da República Portuguesa proclama que "Os preceitos constitucionais respeitantes aos direitos, liberdades e garantias são directamente aplicáveis e vinculam as entidades públicas e privadas". O artigo 43 da Constituição da Nação Argentina, por sua vez, assegura a toda pessoa o acesso à ação expedita e rápida de amparo, dirigida a atos e omissões não só de autoridades públicas, mas também de particulares.

Mas não são apenas estes países que possuem normas constitucionais neste sentido. A atual Constituição sul-africana prevê em seu artigo 8 (2) que : "Uma disposição de direitos fundamentais vincula uma pessoa natural ou uma pessoa jurídica se, e na medida em que fora aplicável levando em consideração a

\footnotetext{
${ }^{49}$ SILVA, Virgílio Afonso da. Op. cit., p. 19.

${ }^{50}$ Ibidem, p. 19.
} 
natureza do direito e a natureza de qualquer dever imposto pelo direito" $"$. A Constituição suíça de 1999, por sua vez, estatui em seu art. 35, 5: “As autoridades públicas devem cuidar para que os direitos fundamentais, a medida em que sejam aptos para tanto, tenham eficácia também nas relações entre privados" ${ }^{, 52}$.

No Brasil, o artigo $5^{\circ}, \S 1^{\circ}$, da CF estatui que "As normas definidoras dos direitos e garantias fundamentais têm aplicação imediata". Há autores, como Leonardo Matiello, que nele fundamentam a aplicação direta dos direitos fundamentais nas relações entre particulares ${ }^{53}$. Virgílio Afonso da Silva critica esta conclusão por entender que a simples prescrição constitucional de que as normas definidoras de direitos fundamentais terão "aplicação imediata" não diz absolutamente nada sobre quais relações jurídicas sofrerão seus efeitos, ou seja, não traz indícios sobre o tipo de relação que deverá ser disciplinada pelos direitos fundamentais. E complementa destacando que o fato de os direitos fundamentais possuírem aplicação imediata não significa que esta aplicação ocorrerá em todos os tipos de relação, tampouco que todos os tipos de relação jurídica sofrerão algum efeito das normas de direitos fundamentais ${ }^{54}$.

Edílson Pereira Nobre Júnior, contudo, afirma-se favorável à vinculação dos particulares aos direitos fundamentais, independentemente de tal constar de disciplina legislativa, ressaltando que parcela ponderável dos direitos fundamentais teria o seu conteúdo esvaziado se não vinculassem diretamente os

${ }^{51}$ A provision of the Bill of Rights binds a natural or a juristic person if, and to the extent that, it is applicable, taking into account the nature of the right and the nature of any duty imposed by the right. Disponível em <http:/www.info.gov.za/documents/constitution/1996/96cons2.htm>.

${ }^{52}$ Article 35 Realization of Fundamental Rights

(1) Fundamental rights have to be effectuated throughout the entire legal system.

(2) Whoever exercises a state function is bound to the fundamental rights and obliged to contribute to their implementation.

(3) The authorities ensure that fundamental rights, as far as they are suitable, also become effective among private parties. Disponível em <www.oefre.unibe.ch/law/icl/sz00000_.html >.

${ }^{53}$ Em suas palavras: "Tal aplicação [dos direitos fundamentais] deve ocorrer nas relações entre o Estado e os indivíduos, bem com nas relações entre particulares, abrigadas no campo civilístico. Os valores e princípios contitucionais devem ter a sua eficácia reconhecida, ademais, não somente quando assimilados pelo legislador ordinário, que os tenha transposto para a legislação infraconstitucional, mas também diretamente às relações entre os indivíduos (a denominada eficácia direta), inclusive em virtude da determinação segundo a qual 'as normas definidoras dos direitos e garantias fundamentais têm aplicação imediata” (MARIETTO, Leonardo. O direito civil constitucional e a nova teoria dos contratos. In: TEPEDINO, Gustavo (coord). Problemas de direito civil constitucional. Rio de Janeiro: Renovar, 2001, p. 167).

${ }^{54}$ SILVA, Virgílio Afonso da. Op cit. São Paulo: Malheiros, 2005, p. 58. 
particulares $^{55}$. Sensível a esta questão, o Supremo Tribunal Federal aplicou a teoria da horizontalização dos direitos fundamentais em decisão majoritária proferida no final de $2005^{56}$.

\section{Rufino do Vale relaciona uma série de razões históricas}

para a adoção da teoria da horizontalização dos direitos fundamentais. Em primeiro lugar, haveria que se superar a dicotomia entre direito público e privado que, diante da progressiva publicização do direito privado e privatização do direito público, subsiste apenas por razões históricas. Em sua opinião, hoje já não se pode falar em esferas estanques e bem delimitadas, mas em "simbiose entre o público e o privado". Uma segunda razão para se reconhecer a eficácia aos direitos fundamentais também nas relações privadas seria o chamado fenômeno do neofeudalismo jurídico, de que decorre

${ }_{56}^{55}$ NOBRE JÚNIOR, Edílson Pereira. Direitos fundamentais...op. cit., p. 35.

56 EMENTA: SOCIEDADE CIVIL SEM FINS LUCRATIVOS. UNIÃO BRASILEIRA DE COMPOSITORES. EFICÁCIA DOS DIREITOS FUNDAMENTAIS NAS RELAÇÕES PRIVADAS. RECURSO DESPROVIDO. I. EFICÁCIA DOS DIREITOS FUNDAMENTAIS NAS RELAÇOES PRIVADAS. As violações a direitos fundamentais não ocorrem somente no âmbito das relações entre o cidadão e o Estado, mas igualmente nas relações travadas entre pessoas físicas e jurídicas de direito privado. Assim, os direitos fundamentais assegurados pela Constituição vinculam diretamente não apenas os poderes públicos, estando direcionados também à proteção dos particulares em face dos poderes privados. II. OS PRINCÍPIOS CONSTITUCIONAIS COMO LIMITES A AUTONOMIA PRIVADA DAS ASSOCIAÇÕES. A ordem jurídico-constitucional brasileira não conferiu a qualquer associação civil a possibilidade de agir à revelia dos princípios inscritos nas leis e, em especial, dos postulados que têm por fundamento direto o próprio texto da Constituição da República, notadamente em tema de proteção das liberdades e garantias fundamentais. O espaço de autonomia privada garantido pela Constituição às associações não está imune à incidência dos princípios constitucionais que asseguram o respeito aos direitos fundamentais de seus associados. A autonomia privada, que encontra claras limitações de ordem jurídica, não pode ser exercida em detrimento ou com desrespeito aos direitos e garantias de terceiros, especialmente aqueles positivados em sede constitucional, pois a autonomia da vontade não confere aos particulares, no domínio de sua incidência e atuação, o poder de transgredir ou de ignorar as restrições postas e definidas pela própria Constituição, cuja eficácia e força normativa também se impõem, aos particulares, no âmbito de suas relações privadas, em tema de liberdades fundamentais. III - SOCIEDADE CIVIL SEM FINS LUCRATIVOS. ENTIDADE QUE INTEGRA ESPAÇO PÚBLICO, AINDA QUE NÃO-ESTATAL. ATIVIDADE DE CARÁTER PÚBLICO. EXCLUSÃO DE SÓCIO SEM GARANTIA DO DEVIDO PROCESSO LEGAL. APLICAÇÃO DIRETA DOS DIREITOS FUNDAMENTAIS À AMPLA DEFESA E AO CONTRADITÓRIO. As associações privadas que exercem função predominante em determinado âmbito econômico e/ou social, mantendo seus associados em relação de dependência econômica e/ou social, integram o que se pode denominar de espaço público ainda que não-estatal. A União Brasileira de Compositores - UBC, sociedade civil sem fins lucrativos integra a estrutura do ECAD e, portanto, assume posição privilegiada para determinar a extensão do gozo fruição dos direito autorais de seus associados. A exclusão de sócio do quadro social da UBC, sem qualquer garantia de ampla defesa, do contraditório, ou do devido processo constitucional, onera consideravelmente o recorrido, o qual fica impossibilitado de perceber os direitos autorais relativos à execução de suas obras. A vedação das garantias constitucionais do devido processo legal acaba por restringir a própria liberdade de exercício profissional do sócio. O caráter público da atividade exercida pela sociedade e a dependência do vínculo associativo para o exercício profissional de seus sócios legitimam, o caso concreto, a aplicação direta dos direitos fundamentais concernentes ao devido processo legal, ao contraditório e à ampla defesa (art. $5^{\circ}$, LIV e LV, CF/88). IV. RECURSO EXTRAORDINÁRIO DESPROVIDO. Recurso Extraordinário RE 201819/RJ, Relator Designado Ministro Gilmar Ferreira Mendes. Publicado no DJ em 27/10/2006 pp 000064). 
perda de funcionalidade e operatividade das constituições na pós-modernidade e resulta na dominação do ambiente social, econômico e político pelos atores privados e neocorporativos, os quais passam a ser dotados de alto poder de auto-regulação e controle local. Para Rufino, “o reconhecimento da dimensão objetiva dos direitos fundamentais permite a esses direitos e à Constituição em que estão inserido o restabelecimento do exercício de uma regulação central, ainda que difusa e à distância, da auto-regulação social" 57 .

Mesmo autores que destacaram os problemas gerados por uma horizontalização ampla e irrestrita dos direitos fundamentais demonstram admiti-las ou pelo menos aceitá-las em relação aos direitos trabalhistas. Virgílio Afonso da Silva, após ponderar que uma das dificuldades para a adoção da teoria dos efeitos horizontais dos direitos fundamentais na Alemanha decorreu da ausência de normas de direitos fundamentais que não aquelas de cunho liberal, sinalizou a possibilidade de adotá-la no Brasil, pelo menos no tocante aos direitos constitucionais trabalhistas $^{58}$.

\footnotetext{
${ }^{57}$ VALE, André Rufino do. Op. cit., p. 72/73. Guilherme Machado Dray, por sua vez, sintetiza o seu ponto de vista asseverando que "Com efeito, sendo certo que o respeito pela dignidade humana continua a ser o fim da sociedade política, a realidade é que a defesa desta dignidade parte da constatação de que o Homem que se visa defender não é o homem liberal, concebido de forma isolada, e a de que a sociedade em que se mostra inserido está longe de defender os mais puros valores liberais, nos termos dos quais a riqueza e o bem estar colectivo eram entendidos como o somatório da riqueza e do bem estar individuais, sendo estes o resultado da actividade dos particulares. Pelo contrário, o Homem cuja dignidade se visa tutelar é homem que vive em sociedade e como parte integrante de um todo comunitário. Assim, a dignidade humana deixa de ser vista como a liberdade individual de cada um, absoluta e indefinida, passando a ser entendida como o livre desenvolvimento da personalidade de homens solidários, que vivem em sociedade e que perante esta são responsáveis. Logo, claro se torna que a defesa da dignidade humana deve ser prosseguida a todos os níveis: quer nas relações entre os particulares e o Estado, quer nas relações que entre estes se estabelecem, sendo absurdo admitir, nessa esteira, que um individuo "pudesse ser livre perante o Estado, não o sendo em sociedade, isto é, nas relações com os seus semelhantes". Por essa razão, o princípio da dignidade da pessoa humana implicaria a vinculação das entidades privadas aos preceitos constitucionais relativos a direitos fundamentais. (DRAY, Guilherme Machado. O principio da igualdade no direito do trabalho: sua aplicabilidade no domínio específico das relações de trabalho. Coimbra: Almedina, 1999, p.143). O autor português, contudo, ressalva que apesar de os preceitos constitucionais se aplicarem, também, às relações privadas, a realidade é que a sua aplicação, imediata, não pode ferir a autonomia privada e a liberdade de contratação, razão pela qual entende existirem certas discriminações que, em determinadas circunstâncias, poderão ser aceitáveis no domínio o Direito Privado (Ibidem, p.175).

${ }^{58}$ In verbis: "Diante disto, é de se supor que, no Brasil, especialmente no âmbito social-trabalhista, a extensão dos direito fundamentais às relações entre particulares seja pouco problemática, em vista, sobretudo, do art. $7^{\circ}$ da Constituição. Isso não significa, contudo, que, em outros âmbitos, especialmente no âmbito jurídico-privado stricto sensu, a tensão entre direitos fundamentais e liberdade privada não existirá" (SILVA, Virgílio Afonso da. Op. cit., p. 25).
} 
Saliente-se, por oportuno, que a teoria da aplicação imediata dos direitos fundamentais às relações entre particulares apresenta singular importância no contexto atual, em que os avanços tecnológicos permitem às empresas uma intromissão na intimidade e na vida privada dos cidadãos. São câmeras que filmam quem se dirige ao banheiro, permitindo inclusive o controle sobre o que tempo que se passa lá. Trocas de informações pessoais por sistema informatizado. Os juslaboralistas e os Tribunais do Trabalho vêm aplicando a teoria da eficácia horizontal dos direitos fundamentais, como denota o seguinte julgado:

INDENIZAÇÃO POR DANOS MORAIS. DISCRIMINAÇÃO NO ATO DA ADMISSÃO. O princípio da igualdade, talhado ao longo dos séculos pelo homem e para o homem, é um autêntico direito fundamental delineador da personalidade humana e dirige-se tanto em face do Estado, quanto do particular, que não pode pautar-se por condutas discriminatórias, preconceituosas ou racistas. (...) (TRT, $3^{\text {a }}$ Região, RO 00951/2005, Relator : Fernando Luiz Gonçalves Rios Neto, DJMG 15.07.2006) ${ }^{59}$

Como não poderia ser diferente, entre as potenciais vítimas de ameaça e de violação a direitos fundamentais por parte de organizações privadas estão inquestionavelmente seus empregados. Com efeito, o estado de subordinação inerente às relações de emprego deixa-os à mercê dos desígnios de empregador, que na sua busca incessante por lucro olvida-se dos direitos fundamentais de seus trabalhadores.

Atento a esta particularidade, Christiana Melis destaca que a primeira e mais importante função dos direitos fundamentais na empresa é atuar como limite aos poderes empresariais. Esta função se desenvolve durante toda a relação de emprego, pois onde se exercem poderes empresariais sempre estará presente a perspectiva limitadora dos direitos fundamentais ${ }^{60}$.

\footnotetext{
${ }^{59}$ Em VIANNA, Cláudia Salles Vilela. Manual 'prático das relações trabalhistas. $8^{a}$ edição. São Paulo: LTr, 2007, p. 49.

${ }^{60}$ MELLIS, Christiana. Derechos fundamentales y empresas: apuntes para una configuración dogmático jurídica. Anuario de Derecho del Trabajo y Seguridad Social n.3/2004, Derechos Fundamentales. Homenaje al Professor Patricio Novoa Funzalida, Sociedade Chilena de Derecho del Trabajo y de la Seguridade Social, p.105-106 apud ROJO, Eduardo Caamaño. El derecho a la no discriminación en el empleo. Santiago: LexisNexis, 2005, p. 15.
} 
A partir destas considerações e da premissa de que o direito à igualdade é, inquestionavelmente, um direito fundamental, nem sequer seriam necessárias normas infraconstitucionais para regulamentá-lo e para tornar ilícita qualquer conduta discriminatória. No Brasil, contudo, dispõe-se de um arcabouço legislativo considerável para combater este tipo de ilícito. É o que se demonstrará oportunamente. 


\section{DIGNIDADE DA PESSOA HUMANA}

Conquanto pondere que reduzir a uma fórmula abstrata e genérica tudo aquilo que constitui o conteúdo da dignidade da pessoa humana não é tarefa das mais fáceis, razão pela qual eventual definição apresentada somente alcançará sentido e operacionalidade em face do caso concreto, Ingo Wolfgang Sarlet finda por conceituá-la como a qualidade intrínseca e distintiva reconhecida em cada ser humano que o faz merecedor do mesmo respeito e consideração por parte do Estado e da comunidade. Consistirá, neste sentido, em um complexo de direitos e deveres fundamentais que asseguram a pessoa tanto contra todo e qualquer ato de cunho degradante e desumano, e lhe garantem as condições existenciais mínimas para uma vida saudável, além de propiciar e promover sua participação ativa e co-responsável nos destinos da própria existência e da vida em comunhão com os demais seres humanos ${ }^{61}$.

Dentro deste complexo de direitos e deveres fundamentais que assegurem à pessoa condições existenciais mínimas para uma vida saudável, além de propiciar e promover sua participação ativa e co-responsável nos destinos da própria existência e da vida em comunhão com os demais seres humanos, encontra-se inquestionavelmente o direito de cada um ao desenvolvimento subjetivo, nas suas vertentes direito ao trabalho, direito à educação que o qualifique para o trabalho e direito à formação profissional, tema de um dos capítulos seguintes. Afinal, não há como se assegurar a alguém condições para uma vida saudável e se garantir sua participação nos destinos da sua própria existência se não se lhe possibilitar acesso ao emprego e não se valorizar seu esforço em se capacitar para ele.

\footnotetext{
${ }^{61}$ SARLET, Ingo Wolfgang. Dignidade da pessoa humana e direitos fundamentais na Constituição Federal de 1988. $5^{\mathrm{a}}$ edição. Porto Alegre: Livraria do advogado editora, 2007, p. 59.
} 
Não obstante se atribua à Grécia antiga a condição de berço da noção de homem como detentor de uma dignidade ${ }^{62}$, foi somente no século XX que se passou a tratar a dignidade da pessoa humana como alicerce da ordem jurídica internacional e dos ordenamentos jurídicos nacionais.

Com efeito, a primeira notícia que se tem da inserção da idéia de dignidade da pessoa humana em um texto normativo remonta à Constituição Alemã de 1919 onde se garantia em seu artigo 151, I, uma existência digna como objetivo maior da ordem econômica ${ }^{63}$. Muito embora a referida Carta tenha exercido forte influencia nos textos normativo-constitucionais elaborados nas décadas seguintes em todo o mundo - essa possivelmente a razão pela qual já na década de 30 as de Portugal e da Irlanda, em seus preâmbulos, tenham mostrado certa preocupação com a dignidade da pessoa humana - somente após a segunda guerra mundial passou-se efetivamente a primar pela sua proteção, elevando-a a condição de preceito fundamental.

Desta feita, foram os horrores verificados na Segunda Guerra Mundial que impulsionaram o movimento pelo respeito da dignidade da pessoa humana, tornando-o uma preocupação universal. A partir de então a imensa maioria das normas de direito internacional e interno dos mais diversos países passaram a tratar a dignidade da pessoa como a sua principal diretriz, ou pelo menos como uma de suas principais diretrizes ${ }^{64}$.

${ }^{62}$ Consoante leciona Firmino Alves de Lima: "A grécia antiga foi o berço da noção do homem como
detentor de uma dignidade. O desenvolvimento da filosofia grega na antiguidade fez o ser humano
visualizar-se no centro do universo, como ser dotado de liberdade e razão e capaz de atingir o
conhecimento" (Mecanismos antidiscriminatórios nas relações de trabalho. São Paulo: LTr, 2006, p.
19). Semelhante é a opinião de Emmanuel Teófilo Furtado, segundo quem "embora não se possa negar a
imensa cotribuição que o Cristianismo trouxe para a compreensão de pessoa e de dignidade humana, não
se pode, por outro lado, olvidar, que lampejos houve em relação a tais questões, quer no período
socrático, quer entre os estóicos" (Preconceito no trabalho e discriminação por idade. São Paulo: LTr,
2004, p.104).
63 SARLET, Ingo Wolfgang. A eficácia... op. cit., p. 104, nota 221 .
${ }^{64}$ José Felipe Ledur além de reconhecer a positivação da dignidade da pessoa humana como corolário
das atrocidades das guerras do século XX, associa-a também ao contexto da revolução industrial, como
se depreende do seguinte extrato: "A dignidade humana foi reconhecida como valor fudamental pelas
constituições, no passado recente. Isso ocorreu no contexto da revoluçao industrial e das duas grandes
guerras deste século, que submeteram o gênero humano ao desprezo e à mais degradante condição. A
idéia de se proteger a dignidade humana nasceu, pois, da violação de direitos de primeira geração,
especialmente a igualdade. Os povos da Europa, que conheceram a tragédia da questão social e as
atrocidades das duas guerras mundiais e da guerra civil espanhola da primeira metade deste século,
perceberam que a pessoa humana estava à mercê da violência e do preconceito sem limites. Diante disso,
o próprio futuro do convívio das pessoas impunha atitude apropriada para savalguardar a humanidade 
Para ilustrar o que foi antes afirmado no tocante ao Direito Internacional, cabe destacar que a Carta das Nações Unidas de 26 de junho de 1945 estabelece, já em seu preâmbulo, que o povo das Nações Unidas reafirma sua fé nos direitos humanos fundamentais, na dignidade e nos valores humanos da pessoa, na igualdade dos homens e mulheres das nações grandes e pequenas. De forma semelhante, a Declaração Americana dos Direitos e Deveres do Homem, de maio de 1948, destaca, também em seu preâmbulo, que todos os homens nascem livres e iguais em dignidades e direitos, expressão, aliás, que foi repetida no artigo $1^{\circ}$ da Declaração Universal dos Direitos do Homem, de 10 de dezembro do mesmo ano ${ }^{65}$.

Mas a corporificação da preocupação com a dignidade da pessoa humana nas normas internacionais não foi um fenômeno verificado com exclusividade nos anos quarenta. Nos anos cinqüenta a Convenção Européia para Proteção dos Direitos Humanos e das Liberdades Fundamentais, de 4 de novembro de 1950, e no início da década seguinte a Carta Social Européia, de 18 de outubro de 1961, assegurando várias situações de proteção da pessoa humana. Isso sem falar na elaboração, na segunda metade dos anos sessenta, do Pacto Internacional de Direitos Civis e Políticos ${ }^{66}$ e do Pacto de Direitos Econômicos Sociais e Culturais ${ }^{67}$, firmados em 19 de dezembro de 1966, que fazem, em seus preâmbulos, remissão aos dizeres do da Declaração Universal dos Direitos do Homem. No final da década, foi elaborada ainda a Convenção Americana de San José da Costa Rica, de 22 de novembro de 1969,

das investidas e riscos que contra ela se levantaram.”. (LEDUR, José Felipe. A realização do direito ao trabalho. Porto Alegre: Sérgio Antonio Fabris Editor: 1998, p. 83).

${ }^{65}$ Analisando a relação entre as atrocidades do conflito bélico e a preocupação ostentada nos referidos pactos internacionais, destacou Firmino Alves Lima que "A Carta das Nações Unidas surgiu ainda com parte do mundo em conflito, dentro do interregno havido entre o término da guerra na Europa, encerrada em 8.5.1945 com a capitulação alemã, ao término da guerra no oriente em 11.8.1945, com a rendição incondicional do império japonês. Sua proclamação foi realizada antes do horror do bombardeio termonuclear das cidades japonesas de Hiroshima e Nagasaki, com centenas de milhares de civis mortos ou gravemente feridos. As demais declarações acima relatadas, seja a Declaração do continente americano ou a Declaração Universal dos Direitos do Homem, foram constituídas poucos anos após o término da $2^{\text {a }}$ Grande Guerra" (op. cit., p. 26).

${ }^{66}$ Reconhecendo que, em conformidade com a Declaração Universal dos Direitos do Homem, o ideal do ser humano livre, no gozo das liberdades civis e políticas e liberto do temor e da miséria, não pode ser realizado a menos que se criem condições que permitam a cada um gozar de seus direitos civis e políticos, assim como de seus direitos econômicos, sociais e culturais(..). Disponível em: $<$ http://www2.mre.gov.br/dai/m_592_1992.htm>. Acesso em 15 de janeiro de 2008.

${ }^{67}$ Considerando que, em conformidade com os princípios proclamados na Carta das Nações Unidas, o reconhecimento da dignidade inerente a todos os membros da família humana e dos seus direitos iguais e inalienáveis constitui o fundamento da liberdade, da justiça e da paz no mundo, Disponível em: 
que, por sua vez, estatui, em seu artigo 11.1, que toda a pessoa tem direito ao respeito de sua honra e ao reconhecimento de sua dignidade.

Mas não foi apenas no âmbito do direito internacional que o período pós-Segunda Grande Guerra consolidou avanços no tocante à positivação da dignidade da pessoa humana. No mesmo período a idéia foi adotada como fundamento em diversos países.

Segundo Firmino Alves Lima, a Constituição Italiana de 1947, embora não faça uso textual da expressão "dignidade da pessoa humana", reconhece e garante os direitos invioláveis do homem, seja como indivíduo, seja nas formações sociais onde se desenvolve sua personalidade ${ }^{68}$.

A Constituição Alemã de 1949, por sua vez, estatui logo em seu artigo $1^{\circ}, \S 1^{\circ}$, que a dignidade de pessoa humana é intangível, estando todos os poderes do Estado obrigados a respeitá-la e protegê-la ${ }^{69}$. De forma similar, a Constituição Portuguesa de 1976, posteriormente reformada em 1982 e 1989, também destaca a questão já em seu primeiro dispositivo, ao pontuar que "Portugal é uma República soberana, baseada na dignidade da pessoa humana e na vontade popular e empenhada na construção de uma sociedade livre, justa e solidária”.

$\mathrm{Na}$ Espanha, por sua vez, o princípio em questão foi consagrado no artigo 10 da Constituição de 1978, onde restou estatuído que "A dignidade da pessoa, os direitos invioláveis que lhe são inerentes, o livre desenvolvimento da personalidade, o respeito à lei e aos direitos dos demais são fundamentos da ordem política e da paz social".

Já a Carta Magna da Bélgica consagra o direito do cidadão de levar uma vida em conformidade com a dignidade humana, tratando-a como um direito objetivo a ser perseguido pelo legislador no momento em que ele vier a

$<$ http://www.direitoshumanos.usp.br/counter/Onu/Sist_glob_trat/texto/texto_2.html $>$. Acesso em 15 de janeiro de 2008.

${ }_{68}^{6}$ LIMA, Firmino Alves de. Op. cit., p. 27.

${ }^{69}$ Art.1(1) Die Würde des Menschen ist unantatbar, Sie zu achten und z schütze ist Verpfchtung aller staatlichen Gewalt. 
erigir outros direitos (art. 23). Segundo Teófilo Furtado, “extrai-se de tal texto que o direito de levar um vida em conformidade com a dignidade humana deverá ser, em curto espaço de tempo, o justificador de todos os outros" ${ }^{\text {70 }}$.

Outros países que também adotaram o postulado em questão no pós-guerra foram República Irlandesa, Índia, Venezuela, Grécia, República Popular da China, Hungria, Namíbia, Colômbia, Bulgária, Romênia, Cabo Verde, Lituânia, Peru, Rússia, África do Sul e Polônia ${ }^{71}$.

No Brasil, a primeira Constituição a mencionar expressamente a dignidade humana foi a de 1946, no Título V, da Ordem Econômica e Social associada ao direito do trabalho. A Constituição de 1967, por sua vez, manteve o dispositivo de forma similar, frisando mais uma vez que a dignidade humana seria princípio da Ordem Econômica e Social.

A Constituição de 1988 também faz a mesma associação, quando no art. 170 valoriza o trabalho humano, além de elevar tal princípio como fundamento da República Federativa.

Segundo Emmanuel Teófilo Furtado, apesar de o respeito à dignidade humana vir sendo apregoado desde a Declaração Universal dos Direitos do homem, apenas nas Constituições mais recentes é que tem ele recebido relevo e até mesmo menção explícita. Para ele "é recente o louvor mais expressivo ao princípio da dignidade da pessoa humana, contemplada numa ótica mais elevada"72. Ainda assim, o referido autor lamenta não estarem doutrina e jurisprudência se dedicando à matéria na proporção de sua importância ${ }^{73}$.

Esta crítica se justifica, sobretudo, na medida em que a dignidade da pessoa humana foi tratada pela Carta Constitucional em vigor como um dos fundamentos da República Federativa do Brasil, o que para Kildare Gonçalves Carvalho implica não apenas o reconhecimento da liberdade, como também na

\footnotetext{
${ }^{70}$ FURTADO, Emanuel Teófilo. Op. cit., p. 117.

${ }_{71}^{71}$ MIRANDA, Jorge. Manual de direito constitucional. $3^{\mathrm{a}}$ edição. Coimbra: Coimbra, 2000. t. 4, p. 180.

${ }^{72}$ FURTADO,Emanuel Teófilo. Op. cit., p. 119.
} 
garantia, a ser propiciada pelo próprio Estado, de condições mínimas de existência à pessoa humana, o que deve ser observado pela ordem econômica, a qual não deve aceitar nenhuma desigualdade no seio da sociedade ${ }^{74}$.

Em diversas ordens constitucionais onde a dignidade da pessoa humana foi objeto de expressa previsão discute-se qual seria o seu correto enquadramento, se como princípio ou como regra. Robert Alexi destaca a existência de um princípio e de uma regra de dignidade da pessoa humana. Aquele estaria sujeita à harmonização com os demais princípios. Esta, remata o autor, seria uma regra absoluta $^{75}$. Ingo Wolfgang Sarlet, analisando o ordenamento constitucional brasileiro,

${ }^{73}$ Ibidem, p. 119.

${ }^{74}$ CARVALHO, Kildare Gonçalves. Direito constitucional didático. $3^{\mathrm{a}}$ ed. Belo Horizonte: Del Rey, 1994, pp. 57-58. Christiani Marques, também traçou importante paralelo entre a dignidade da pessoa humana considerada por ela um princípio, e o postulado da igualdade ao observar que: Dentre os princípios fundamentais inseridos na Constituição Federal, por ora, o que merece maior atenção, tendo em vista seu alcance, é o princípio da dignidade humana (art. $1^{\circ}$, inciso III). No entanto, esse princípio, para atender a finalidade de buscar tal condição, deve ser combinado com o art. $3^{\circ}$, inciso IV, o qual tem por finalidade promover o bem de todos, sem preconceitos e quaisquer formas de discriminação. (MARQUES, Christiani. O contrato de trabalho e a discriminação estética. São Paulo: LTr, 2002, p. 140). No mesmo sentido é o magistério de Emanuel Teófilo Furtado: "dignidade da pessoa humana e isonomia são princípios constitucionais que caminham próximos, sendo que o primeiro antecede o segundo, uma vez que todo ser humano é credor de ver preservada sua dignidade e por tal razão, em relação a outro ser humano, há de merecer igual tratamento, pena de estar sendo diminuído em sua dignidade em relação ao que está sendo beneficiado, e ao mesmo tempo estar sendo vilipendiado em seu direito de usufruir, em situações iguais, de tratamentos iguais”. E conclui asseverando ser o princípio da isonomia uma confirmação do princípio da dignidade da pessoa humana, porquanto se para $\mathrm{A}$, enquanto indivíduo e pessoa, há de ser preservada sua dignidade, $\mathrm{B}$, igualmente indivíduo e pessoa, há de merecer o mesmo tratamento, sob pena de se esquecer, num primeiro plano, a dignidade com a qual B deve ser tratado, e, num segundo plano, restar ferido o princípio constitucional que determina que os iguais devem ser tratados igualmente (Op. cit., p . 132).

75 "Que el principio de la dignidad de la persona, a los fines de la constatación del contenido de la regla de la dignidad de la persona, es ponderado frente a otros princípios se muestra de manera especialmente clara en el fallo sobre la prisón perpetua en donde se dice que la 'dignidad de la persona [...] tampouco es lesionada cuando la ejecución de la pena es necesaria debido a la permanente peligrosidad del detenido y, por esta razón, no está permitido el indulto'. Con esta formulación se constata que la protección de la 'comunidad estatal', bajo las condiciones indicadas, precede al principio de la dignidade de la persona. Si se dan otras condiciones, la preferencia puede ser fijada de otra maneira. Por lo tanto, hay que partir de dos normas de la dignidade de la persona, es decir, una regla de la dignidad de la persona y un principio de la dignidade de la persona. La relación de preferencia del principio de la dignidad de la persona con respecto a principios opuestos decide sobre el contenido de la regla de la dignidade de la persona. Absoluto no es el principoo sino la regla que, debido a su apertura semántica no necesita una limitación con respecto a ninguna relación de preferencia relevante. El principio de la dignidade de la persona puede ser realizado en diferentes grados. El que bajo determinadas condiciones, con un alto grado de certeza preceda a todos los otros princípios no fundamenta ninguna absolutidad del princípio sino que simplemente significa que casi no existem razones jurídico-constitucionales inconmovibles para una relación de preferencia en favor de la dignidade de la persona bajo determinadas condiciones. Pero, una tesis tal de posición central vale también para otras normas de derecho fundamental. Ella no afecta el caráter de princípio. Por eso, puede decirse que la norma de la dignidad de la persona no es un principio absoluto. La impresión de absolutidad resulta del hecho de que existen dos normas de dignidade de la persona, es decir, una regla de la dignidad de la persona y un principio de la dignidad de la persona 
destaca que a dignidade pessoa humana apresenta-se, simultaneamente, como princípio e norma embasadora de direitos fundamentais ${ }^{76}$.

Segundo o referido autor o reconhecimento da condição normativa da dignidade, assumindo a feição de princípio e de regra constitucional fundamental, não afasta o seu papel como valor fundamental geral para toda a ordem jurídica (e não apenas para esta), mas, pelo contrário, outorga a este valor uma maior pretensão de eficácia e efetividade ${ }^{77}$.

Para os fins do presente trabalho, mais importante do que analisar as divergências doutrinárias acerca da natureza do dispositivo que consagra a dignidade da pessoa humana, é demonstrar a sua importância como preceito norteador das demais regras e princípios. Segundo Maria Celina Bodin de Moraes, para quem, em caso de eventual conflito entre princípios de igual importância hierárquica, o fiel da balança, a medida de ponderação, o objetivo a ser alcançado, já estão determinados em favor do conceito da dignidade humana ${ }^{78}$. Isto porque ao admitir a possibilidade de existir situação na qual o por ela considerado princípio da dignidade da pessoa humana não se mostre o de maior importância, a autora admite que ele não possui o caráter absoluto defendido por alguns. E ao asseverar que em condições de igualdade o princípio da dignidade da pessoa humana deve se sobrepor a qualquer

(ALEXY, Robert. Teoria de los derechos fundamentales. Centro de Estudios Políticos y Fundamentales: Madrir, 2001, pp. 108/109).

${ }^{76}$ Em suas palavras: "O artigo $1^{\circ}$, inciso III, de nossa Lei Fundamental não contém apenas (embora também e acima e tudo) uma declaração de conteúdo ético e moal, mas que constitui norma jurídicopositiva dotada, em sua plenitude, de status constitucional formal e material e, como tal, inequivocamente carregado de eficácia, alcançando, portanto - tal como sinalou Benda - a condição de valor jurídico fundamental da comunidade”. (SARLET, Ingo Wolfgang. Dignidade... op. cit., p. 72).

${ }^{77}$ Ibidem, p. 72.

${ }^{78}$ MORAES, Maria Celina Bodin de. O conceito de dignidade humana: substrato axiológico e conteúdo normativo. In: SARLET, Ingo Wolfgang (Org). Constituição, Direitos Fundamentais e Direito Privado. Porto Alegre: Livraria do Advogado, 2003, p. 117. Emmanuel Teófilo Furtado destaca o relevante papel da dignidade da pessoa humana na estrutura constitucional como fonte jurídico-positiva dos direitos fundamentais, aduzindo o seguinte: "Assim como temos a forma de hermenêutica constitucional de interpretação conforme a Constituição, podemos afunilar tal maneira de interpretar a norma constitucional e em determinadas situações fazer uma interpretação conforme os direitos fundamentais constitucionalmente garantidos, os quais se escudam em valores e princípios constitucionais, de tal sorte que mencionados direitos fundamentais conformem a decisão de qualquer instância judicial, observando, assim, o sistema jurídico hierárquico-axiológico. É de se notar de tal interpretação conforme os princípios constitucionais, mormente o da dignidade da pessoa humana, prestam-se a corroborar para o ativismo judicial, que em nada mais consiste senão no comprometimento do Poder Judiciário com a construção política do desenvolvimento social” (op. cit., p. 129). 
outro, ela atesta a sua importância e primazia interpretativa. Primazia, aliás, que vem sendo consagrada nos pretórios brasileiros, como dão conta os seguintes julgados:

A dignidade da pessoa humana, um dos fundamentos do Estado Democrático de Direito, ilumina a interpretação da lei ordinária. (STJ, DJU 26.3.01, p. 473, HC 9.892-RJ, Rel. Orig Min. Hamilton Carvalhido, Red. Para o acórdão Min. Fontes de Alencar $)^{79}$.

Vivemos o momento da valorização da dignidade da pessoa humana (artigo $1^{\circ}$, III, da CF) e todo o esforço interpretativo da legislação infraconstitucional é canalizado para a vitória deste princípio, que é sustentáculo da felicidade existencial do homem. (TJSP, ADV 19-01/299, n. 97046, AC 115.9784/0, Rel. DE. Ênio Santarelli Zuliani) ${ }^{80}$.

Em outra clara hipótese de utilização da regra da dignidade da pessoa humana como parâmetro interpretativo, decidiu o E. Tribunal de Justiça do Rio de Janeiro que a revolta de detentos frente a condições desumanas e atentatórias à sua dignidade não tipifica o delito previsto no artigo 354 do Código Penal:

Não configura motim a revolta coletiva de detentos em xadrez policial frente a condições desumanas e atentatórias à sua dignidade, rebelando-se contra as violações de seus direitos naturais e reivindicando melhor tratamento. Para a caracterização do crime de que cuida o artigo 354 do C.P., há que se ter em conta a liceidade do recolhimento em estabelecimento prisional tal como definido na L.E.P., com violência a pessoas às instalações carcerárias, vale dizer, contra guardas, funcionários ou contra outros detentos não solidarizados com as atitudes amotinadas de seus companheiros de infortúnio (TJRJ, DORJ 7.11,01, p. 331, HC 1.120/01, Rel. Des. E. Mayr $)^{81}$

Firmino Alves de Lima destaca a existência de outras duas funções da dignidade da pessoa humana, também considerada por ele um princípio, além da hermenêutica. Seriam elas a função de caráter políticoorganizacional do Estado brasileiro, responsável por impedir uma conduta positiva

\footnotetext{
${ }^{79}$ BARROSO, Luís Roberto. Constituição da República Federativa do Brasil anotada. $5^{\mathrm{a}}$ edição. São Paulo: Saraiva, 2006, P. 13.

${ }^{80}$ Ibidem, p. 13.

${ }^{81}$ Ibidem, p. 19.
} 
inversa à da clássica abstenção liberal, para tornar eficaz a dignidade do indivíduo; e função vedatória, decorrente da proibição de condutas atentatórias à essência da pessoa humana, impondo limites e freios à ação do Estado ou de quem quer seja, para que não agridam os valores elementares do ser humano ${ }^{82}$. Exemplo de decisão em que se vislumbra a utilização do princípio da dignidade da pessoa humana em sua função vedatória é o seguinte precedente do TST:

Caracteriza atitude discriminatória ato de empresa que, a pretexto de motivação de ordem técnica, dispensa empregado portador de vírus HIV sem a ocorrência de justa causa e já ciente à época o estado de saúde em que se encontrava $\mathrm{o}$ empregado. $\mathrm{O}$ repúdio à atitude discriminatória, objetivo fundamental da República Federativa do Brasil - artigo $3^{\circ}$, inciso IV -, e próprio respeito à dignidade da pessoa humana, fundamento basilar do Estado Democrático de Direito - artigo $1^{\circ}$, inciso III -, sobrepõe-se à própria inexistência de dispositivo legal que assegure ao trabalhador portador do vírus HIV estabilidade no emprego (TST, ADV 20-04/309, n. 109801, E-RR 439.041/98, Rel. Min. João Dalazen) ${ }^{83}$.

Para o presente estudo, o princípio da dignidade da pessoa humana apresenta palmar importância por servir de fundamento para a consagração do direito ao desenvolvimento e do princípio da igualdade ${ }^{84}$ e por orientar a exegese e a aplicação do ordenamento jurídico em vigor, nos casos de violação a estes postulados.

Segundo Kildare Gonçalves de Carvalho, a dignidade da pessoa humana constituir-se-ia em referência constitucional unificadora de todos os direitos fundamentais, devendo, por tal razão, seu conteúdo ser compreendido com caudalosa valoração que encare seu sentido normativo-constitucional, afastando-se, tanto quanto possível, uma noção superficial da essência do próprio homem, de tal

\footnotetext{
${ }^{82}$ LIMA, Firmino Alves. Op. cit., p. 35.

${ }^{83}$ BARROSO, Luís Roberto. Op cit, p. 39.

${ }^{84}$ Segundo Ingo Wolfgang Sarlet: "Também o direito geral de igualdade (princípio isonômico) encontrase diretamente ancorado na dignidade da pessoa humana, não sendo por outro motivo que a Declaração Universal da ONU consagrou que todos os seres humanos são iguais em dignidade e direitos. Assim constitui pressuposto essencial para o respeito da dignidade da pessoa humana a garantia da isonomia de todos os seres humanos, que, portanto, não podem ser submetidos a tratamento discriminatório e arbitrário, razão pela qual não podem ser toleradas a escravidão, a discriminação racial, perseguições por motivos de religião, sexo, enfim, toda e qualquer ofensa ao princípio isonômico na sua dupla dimensão formal e material”. (SARLET, Ingo Wolfgang. Dignidade...op cit, p. 87).
} 
sorte que se arrede qualquer idéia apriorística do homem, sendo inaceitável que se estabeleça um reducionismo do verdadeiro sentido da dignidade humana à restrita defesa dos direitos tradicionais, se deixando de lado os direitos sociais, ou simplesmente fazer menção a tal princípio tão-somente para edificar a teoria do núcleo da personalidade individual, olvidando quando a questão for garantia das bases do existir do homem ${ }^{85}$.

A partir destes ensinamentos impõe-se a conclusão de que, para a harmonização deste desiderato constitucional, a ordem econômica tenha por escopo propiciar a todos vida digna, bem como possa a ordem social contribuir para a implementação de uma justiça social, a educação, por sua vez, vir a dar lugar ao pleno desenvolvimento da pessoa humana, bem como o necessário embasamento para que venha a exercer a cidadania ${ }^{86}$. Vê-se, portanto, que é justamente o postulado da dignidade da pessoa humana que serve de sustentáculo ao princípio da isonomia e ao direito ao desenvolvimento, ambos imprescindíveis para as conclusões apresentadas neste trabalho.

\footnotetext{
${ }^{85}$ CARVALHO, Kildare Gonçalves de. Op. cit., p 120

${ }^{86}$ FURTADO, Emmanuel Teófilo. Op. cit., p. 121.
} 


\section{PRINCÍPIO DA IGUALDADE}

\subsection{EVOLUÇÃO HISTÓRICA DO CONCEITO DE IGUALDADE}

De acordo com as lições de Fábio Konder Comparato, "foi durante o período axial da História que despontou a idéia de uma igualdade essencial entre todos os homens". Essa idéia, contudo, não emergiu de forma homogênea em todas as sociedades e momentos históricos, incorporando, ao contrário, manifestações diversas ao longo do tempo, variando conforme a época, a cultura e os valores vigentes, o que torna o estudo dos valores e costumes das diferentes sociedades requisito essencial para a compreensão de sua evolução e do estágio em que se encontra atualmente nos diversos ordenamentos jurídicos e na esfera internacional. $\mathrm{O}$ autor português Guilherme Machado Dray observa com muita propriedade que "no plano jurídico o conceito de igualdade revela-se historicamente como uma idéia dinâmica, constantemente adaptável ao dever social e às mutações operadas na sociedade" ${ }^{\$ 7}$. Aduz ainda que por se tratar de uma idéia centrada no homem e na afirmação da dignidade, o princípio ora estudado "desenvolveu-se, não raras vezes, através do impulso emergente das classes mais desfavorecidas e de forma casuística, tendo em vista a superação de situações concretas de desigualdades naturais, jurídicas, reais ou factuais" ${ }^{\prime 8}$.

Estudando a evolução histórica do princípio da igualdade, ou melhor do ideal de igualdade que resultou nele, percebe-se que, embora a consagração definitiva da igualdade perante a lei surja após a transição para o Estado Moderno, a idéia de tratamento igualitário e antidiscriminatório remonta a épocas bem mais remotas. Ao longo desta evolução, é possível identificar inúmeras concepções

\footnotetext{
${ }^{87}$ DRAY, Guilherme Machado.Op. cit., p. 19.

${ }^{88}$ Ibidem, p. 19.
} 
atribuídas ao referido postulado, entre as quais três merecem destaque: o princípio da igualdade perante a lei enquanto realidade de índole formal, o princípio da igualdade perante a lei numa acepção material e o princípio geral da igualdade de oportunidades enquanto projeto de igualdade real.

Guilherme Machado Dray atribui aos estóicos e ao cristianismo a proclamação do princípio da igualdade entre todos os homens de qualquer condição, como princípio fundamental da existência humana ${ }^{89}$.

O autor lusitano nega responsabilidade pela origem do princípio em questão aos filósofos gregos em razão deles falarem sobre igualdade em sociedades escravocratas, sendo os estóicos e os cristãos os primeiros a defender a extensão do tratamento igualitário até mesmo aos escravos. Em sua obra, o autor lusitano destaca que os renomados filósofos Platão e Aristóteles escreviam para os cidadãos livres, e que a sociedade em que viviam aceitava e concebia o regime da escravidão como algo natural, erro que somente seria corrigido pelos estóicos. Segundo Dray, coube a estes, efetivamente, a superação do inigualitarismo de base existente entre os homens, bem como a repulsa pela concepção da escravatura como algo natural. Neste sentido Cícero proclamaria a igualdade natural entre todos os homens, ao passo que Sêneca afirmaria a natureza idêntica entre o escravo e seu amo. Diante destas ponderações, o autor lusitano conclui com perfeição que "A igualdade é assim elevada a princípio fundamental da existência humana, sendo finalmente afirmada a idéia de que todos os homens são naturalmente iguais e de que esta mesma igualdade é essência da Justiça" 90 .

Por mais que se concorde com as ponderações do autor lusitano, há que se reconhecer que o tema da igualdade de tratamento já era abordado e ocupava a mente dos filósofos gregos; sendo certo que de suas construções filosóficas brotaram muitos dos conceitos que hoje dão suporte ao tema. Em verdade, a convicção

\footnotetext{
${ }^{89}$ DRAY, Guilherme Machado. Op. cit., p. 23. No tocante às sociedade orientais, tantas vezes olvidadas em nossos estudos, alguns autores identificam ideais igualitários nos ensinamentos de Buda e Confúcio. Neste sentido o magistério de Lucylla Tellez Merino, segundo quem "Também no Oriente a visão da igualdade entre os homens, já bem mais aproximada da ótica cristã, se fez florecer, nos ensinamentos de Buda e Confúcio, o primeiro disseminando valores éticos de tolerância, respeito, generosidade, e o segundo divulgando sua doutrina de altruísmo, no reconhecimento do caráter de justiça no agir igualitário". (Op. cit., p. 36).
} 
de que todos os seres humanos têm direito a serem igualmente respeitados, pelo simples fato de sua humanidade, segundo as lições de Fábio Konder Comparato, nasce vinculada a uma instituição social de capital importância: a lei escrita, como regra geral e uniforme, igualmente aplicável a todos os indivíduos que vivem numa sociedade organizada. E, conquanto a lei escrita tenha alcançado entre os judeus uma posição sagrada, como manifestação da própria divindade, foi na Grécia, particularmente em Atenas, que a preeminência da norma escrita tornou-se, pela primeira vez, o fundamento da sociedade política ${ }^{91}$.

Os gregos distinguiam três espécies de igualdades: a isonomia, ou igualdade perante a lei; a isegoria, que seria o igual direito de levantar-se para aconselhar a cidade, o direito de falar nas assembléias da cidade; e a isocrítica, possibilidade do interlocutor criticar o falante e o conteúdo de sua as assertivas ${ }^{92}$. Aplicando estes conceitos aos nossos tempos, Lutiana Nacur Lorentz, asseverou que, modernamente, a isonomia (ou isotopia) liga-se, em seu aspecto mínimo mais superficial, às noções de generalidade, de abstração da lei e à necessidade de sua obediência obrigatória para a sociedade, ao executivo, ao legislativo, ao judiciário, etc.; enquanto isegoria estaria ligada ao direito de votar e ser votado (repelindo os votos censitários, a exclusão de determinadas categorias de elegibilidade, etc.), além da participação em igualdade de condições nos processos judicial e administrativo; e isocrítica à possibilidade de participação nos devidos processos legislativo judiciário e administrativo através da perspectiva da crítica aberta às partes com aplicação da ampla defesa ${ }^{93}$.

Acerca dos gregos, Guilherme Machado Dray destaca que muito embora os pré-socratícos, em especial Heráclito, Empédocles, Demócrito e Alcidamante, já defendessem a idéia de igualdade entre os homens, permanente e duradoura, incorruptível e universal, foi somente com Platão que ela mereceu maiores desenvolvimentos. Neste grande filósofo pode-se ler "Nós e os nossos, que somos

\footnotetext{
${ }^{90}$ DRAY,Guilerme Machado. Op. cit., p. 23/25.

${ }^{91}$ COMPARATO, Fábio Konder. Op. cit., p. 12.

${ }^{92}$ LORENTZ, Lutiana Nacur. A norma da igualdade e o trabalho das pessoas portadoras de deficiência. São Paulo: LTr, 2006, p. 35.Carlo Cursio, citado por Guilherme Machado Dray (op. cit., p. 23) apresenta nomenclatura diversa e conceitos um pouco díspares. Segundo ele: “os gregos distinguiam três espécies de igualdades: a isonomia, ou igualdade perante a lei; a isotimia, ou igual direito dos cidadãos de ocupar cargos públicos; e a isegoria, ou igual direito de exprimir com a palavra o próprio pensamento".
} 
todos irmãos, nascidos de uma mãe comum, não nos olhamos como escravos, nem como mestres uns dos outros; mas a igualdade de origem estabelecida pela natureza nos obriga a procurar a igualdade política e a não reconhecer outra superioridade senão a da virtude e da sabedoria" ${ }^{94}$.

Leila Pinheiro Bellintani observa que pensadores antigos como Sólon e Péricles já enunciavam a sua importância como um elemento essencial da justiça. Quanto a Platão, ela afirma que em seus escritos haveria a defesa de uma igualdade de oportunidades entre os indivíduos em determinados aspectos da vida social, tais como o acesso aos cargos públicos ${ }^{95}$.

Aristóteles, por sua vez, em sua clássica obra Política, concebia justiça como o tratamento igualitário entre os iguais e desigual entre os desiguais ${ }^{96}$. Esta observação mereceu críticas de Leila Bellitani, para quem soa contraditório o filósofo grego associar justiça e igualdade ao mesmo tempo em que defendia a desigualdade como algo natural, argumento utilizado para justificar a existência e a perpetuação da escravidão ${ }^{97}$.

\footnotetext{
${ }^{93}$ LORENTZ, Lutiana Nacur. Op. cit., p. 37.

${ }^{94}$ DRAY, Guiherme Machado. Op. cit., p. 24/25.

${ }^{95}$ BELLINTANI, Leila Pinheiro. Ação afirmativa e os principios do direito: a questão das quotas raciais para Ingresso no Ensino Superior no Brasil. Rio de Janeiro: Lumen Juris, 2006, p. 9.

96 "Todos os homens se apegam a algum tipo de justiça, mas a concepção de cada um é imperfeita e não expressa a idéia completa. Por exemplo, alguns pensam que justiça é igualdade, e efetivamente o é, embora não o seja para todos e sim para aqueles que são iguais entre si. Também se pensa que a desigualdade pode ser justa, e de fato o pode, mas não para todos e sim para aqueles que são desiguais entre si. Também se pensa que a desigualdade pode ser justa, e de fato o pode, mas não para todos e sim para aqueles que são desiguais entre si”. (Aristóteles. Política. Tradução de Politikón, cotejada com a tradução inglesa de Benjamim Jowet e a tradução francesa de M. Thurot. São Paulo: 2006, p. 126). Em outra passagen destacou ainda: "os homens que são iguais em uma só coisa não devem ser considerados iguais em todas as outras coisas, nem os desiguais acerca de uma só coisa devem ser considerados desiguais em todas as outras coisas, conclui-se que todas as formas de constituição baseadas em uma igualdade o desigualdade são perversões da constituição ideal"(Ibidem, p. 134) e "A igualdade consiste em dar o mesmo tratamento a pessoas semelhantes" (Ibidem, p. 256). Norberto Bobbio após ponderar que "o conceito e o valor da igualdade mal se distinguem do conceito e do valor da justiça na maioria de suas acepções, tanto que a expressão liberdade e justiça é freqüentemente utilizada como equivalente da expessão liberdade e igualdade"(BOBBIO, Norberto. Igualdade e liberdade. $2^{\mathrm{a}}$ edição. Rio de Janeiro: Ediouro, 1997, p.14), conclui asseverando que "Se se quer conjugar os dois valores supremos da vida civil, a expressão mais correta é liberdade e justiça e não liberdade e igualdade, já que a igualdade não é por si mesma um valor, mas o é somente na medida em que seja uma condição necessária, ainda que não suficiente, daquela harmonia do todo, daquele ordenamento das partes, daquele equilíbrio interno de um sistema que mereça o nome de justo" (ibidem, p. 16).
}

${ }^{97}$ BELLINTANI, Leila Pinheiro. Op. cit., p. 9. 
Essa contradição exposta no pensamento de Aristóteles é posteriormente corrigida por Sêneca e por Cícero, que propagam que os homens são sim iguais entre si e que os escravos são da mesma natureza que os seus amos. Estabelece-se, então, a natureza igualitária entre os seres humanos ${ }^{98}$.

A idéia de igualdade entre todos os homens, de amor concedido para o homem pelo simples fato de ser ele humano, independentemente de qualquer distinção exterior, inclusive no que se refere à nacionalidade, veio a se consolidar grandemente com o cristianismo. Sobretudo, porque, como salienta Lucylla Tellez Merino, “a partir do advento de Jesus superou-se a errônea divulgação de que só havia um povo escolhido, no sentido geográfico ou racista aplicado ao vocábulo"99.

Guilherme Dray constata ainda que a igualdade natural no homem, como conseqüência necessária do direito natural, teria sido igualmente afirmada nos grandes textos jurídicos romanos e na doutrina dos Padres da Igreja, sendo unânime o reconhecimento de que a escravatura era uma criação (perversa) da humanidade ${ }^{100}$.

Em especial o autor lusitano destaca os ensinamentos de Santo Agostinho, para quem o Direito, ou o justo, seria o que pela sua própria natureza é adequado ou ajustado à medida de alguém, e a Justiça seria a virtude que dá a cada um o seu, ou o quanto lhe é devido. Assim, a lei só poderia ser justa quando contemplasse a idéia de igualdade, pelo que Dray conclui que a igualdade seria requisito essencial da lei ${ }^{101}$.

O mesmo autor pondera ainda que Santo Agostinho teria retomado a clássica distinção de Aristóteles entre justiça aritmética e justiça geométrica, para elaborar a sua distinção entre a justiça comutativa (ou sinalagmática) e a justiça distributiva. A primeira relativa à relação entre as pessoas privadas, exigindo uma absoluta igualdade na troca ou comutação entre privados. A segunda, por sua vez, referir-se-ia às relações entre os cidadãos e o poder político instituído, exigindo apenas

\footnotetext{
${ }^{98}$ Ibidem, p.9.

${ }^{99}$ MERINO, Lucyla Tellez. Op. cit., p. 37.

${ }^{100}$ DRAY, Guilherme Machado. Op. cit., p. 26.
} 
que os representantes da comunidade repartissem os encargos segundo a capacidade de resistência de cada membro da sociedade e os bens públicos de acordo com a respectiva dignidade e mérito. Segundo o português, para Aristóteles, na justiça distributiva não se exigia uma igualdade absoluta, mas sim a atribuição a cada um daquilo que lhe era digno, uma vez que tratar igualmente o desigual traduzir-se-ia seguramente numa desigualdade ${ }^{102}$.

$\mathrm{Na}$ Época Medieval, por sua vez, distinguiam-se os comandos gerais e os comandos particulares. Aqueles caracterizados por seu caráter genérico e abstrato e qualificados como Leis, estes por seu caráter pessoal ou individual eram chamados Privilégios ${ }^{103}$.

Segundo Dray, a idéia então proclamada era de que a igualdade, imposta pela Justiça, deveria estar associada à generalidade da lei, afastando-se conseqüentemente da concessão de privilégios.

A admissão de maneira inequívoca da igualdade jurídica (civil), coube, a Rousseau, na linha iluminista da filosofia do século XVIII, cujos ideais viriam a ser proclamados na Revolução Francesa de $1789^{104}$.

O referido iluminista concebia nos seres humanos duas espécies de desigualdade: uma chamada natural ou física, estabelecida pela natureza e consistente na diferença das idades, da saúde, das forças do corpo e das qualidades do espírito ou da alma; e outra, que se pode chamar de desigualdade moral ou política, dependente de uma espécie de convenção, estabelecida ou, pelo menos, autorizada ou consentida pelos homens ${ }^{105}$. A primeira das formas de desigualdade, seria, segundo o iluminista francês, de influência quase nula. A segunda forma é que deveria realmente ser combatida quando não concorrer na mesma proporção com a desigualdade física ${ }^{106}$.

\footnotetext{
${ }^{101}$ Ibidem, p. 26.

${ }^{102}$ Ibidem, p. 26.

103 Ibidem, p. 27.

${ }^{104}$ Ibidem, p. 28.

105 ROUSSEAU, Jean-Jacques. Discurso sobre a origem e os fundamentos da desigualdade entre os homens. São Paulo: Martin Claret, 2006, p. 31.

106 "a desigualdade, sendo quase nula no estado de natureza tira sua força e o seu crescimento do desenvolvimento de nossas faculdades e dos progressos do espírito humano, tornando-se enfim estável e legítima pelo estabelecimento da propriedade e das leis. Resulta ainda que a desigualdade moral
} 
Não tardou para os novos ensinamentos saírem do papel e passarem ao Direito positivo, sendo adotadas pelas teorias do Constitucionalismo liberal. Desta feita, restaram incorporados pelas constituições americanas de 1787 e francesa de 1793, que se assentavam em um modelo liberal que postula a proclamação da igualdade no momento da aplicação da lei ${ }^{107}$.

Guilherme Machado Dray conclui, de modo irreparável, que a igualdade, da forma como então concebida, se assentava exclusivamente num processo de aplicação da lei e não na fase de criação do direito, possuindo, outrossim, natureza exclusivamente formal ${ }^{108}$. Estava-se passando para uma nova forma de abordagem do problema da igualdade. A igualdade não mais era encarada como algo intimamente associado à noção de Justiça, mas sim a partir de uma idéia de relacionamento do homem com o poder político. Em suas palavras, "o constitucionalismo vem, nos termos enunciados, formalizar a igualdade como uma negação de privilégios e erigir, paralelamente ao direito de igualdade, um dever ou obrigação de igualdade"109.

Tem-se, assim, a primeira entre as três fases distintas e bem definidas da evolução do princípio da igualdade, apontadas pela doutrina ${ }^{110}$. Neste primeiro momento, ele aparece basicamente confundido com o princípio da prevalência da lei. Prevalecia então uma visão meramente formal do princípio e estava implícita a idéia do tratamento igual pela norma em termos absolutos. Em outras palavras, embora

autorizada unicamente pelo direito positivo, é contrária ao direito natural todas as vezes que não concorre na mesma proporção com a desigualdade fisica". (Ibidem, pp. 87/88).

107 DRAY, Guilherme Machado. Op. cit., p. 28. Esclarecedoras são as lições de Guilherme Machado Dray: "O princípio da "igualdade perante a lei" emerge, no essencial, dos movimentos revolucionários do século XIX que despontaram na América do Norte e em França e que deram origem a um elemento capital da política moderna: o constitucionalismo. Trata-se de uma concepção que assenta na idéia de que todos os homens são iguais perante a lei e de que todos os cidadãos são iguais em direitos e deveres. Ou seja, não é a igualdade que está "perante" a lei, mas sim os indivíduos. São os indivíduos, ontologicamente tidos como iguais, que estão perante a lei, sendo absurdo pensar, por esta razão, que a igualdade dos indivíduos perante a lei se pudesse exprimir na própria lei e no seu acto de criação" (op. cit., p. 29). Segundo Vera Lúcia Carlos, "Foi com inspiração na idéias de Rousseau que os revolucionários franceses passaram a defender o princípio da soberania popular e da igualdade de direitos, impondo ao Estado o dever de editar regras gerais e impressoais, com a finalidade de acabar com a diferença de tratamento entre os povos"(CARLOS, Vera Lúcia. Discriminação nas relações de trabalho. São Paulo: Editora Método, 2004, p. 20).

${ }^{108}$ Ibidem, p. 20.

109 Ibidem, pp. 29/30.

${ }^{110}$ BELLINTANI, Leila Pinheiro. Op. cit., p. 10. 
se reconhecesse a existência de desigualdade entre homens, estas eram tidas por irrelevantes quando da elaboração e aplicação dos dispositivos legais. Segundo a referida autora, os legisladores e intérpretes de então trabalhavam sempre presos ao paradigma de que todos os homens estariam sujeitos às mesmas condições e adversidades sociais, e deveriam, portanto, ser normativamente equiparados. Para eles o que importava, de fato, era que todos os indivíduos estivessem submetidos às mesmas regras ${ }^{111}$.

Essa concepção, não obstante tenha representado importante avanço por ter resultado na diminuição dos privilégios de nascimento e de condição social, não se mostrou suficiente para implantar na sociedade um verdadeiro tratamento igualitário. Passa-se, então, a enfocar o princípio da igualdade de uma maneira diversa da anterior, abandonando-se a idéia de que haveria uma eqüidade absoluta entre os homens, e adotando a idéia de relatividade, em que o indivíduo é visto como um ser social, na medida em que suas relações sociais o relativizam. Percebe-se então a necessidade de fomentar meios jurídicos capazes de combater tais anomalias sociais $^{112}$.

Surgem duas novas concepções do princípio da igualdade, a vedação da discriminação e a proibição do arbítrio, ambas com o escopo de eliminar preconceitos e discriminações verificados no seio das sociedades. É o momento em que são inseridos nas legislações tipos penais criminalizando condutas discriminatórias $^{113}$.

Tampouco a simples vedação às discriminações e proibição do arbítrio se mostraram capazes de instaurar uma igualdade verdadeiramente substancial. Atentou-se, nesse momento, para a necessidade de promoção de medidas que efetivassem a ascensão das classes desprivilegiadas. A máxima de que os iguais deveriam ser tratados como iguais e os desiguais como desiguais passou a não mais estar associada a uma concepção meramente formal, em que as discriminações legais não eram possíveis. Reconheceu-se que a norma deveria

\footnotetext{
${ }^{111}$ BELLINTANI, Leila Pinheiro. Op. cit., pp. 10/11.

112 BELLINTANI, Leila Pinheiro. Op. cit., pp. 11/12.

${ }^{113}$ Ibidem, p. 12.
} 
realmente tratar os desiguais desigualmente, concedendo-lhes certos benefícios, para que pudessem aproximar-se dos demais, ou seja, daqueles que não foram desprivilegiados e tiveram oportunidade de ascender socialmente ${ }^{114}$.

Mudado o entendimento em relação a esta questão, deparou-se com um novo problema, identificar quais características deveriam ser consideradas como mecanismos de comparação entre os homens, para que fossem concedidos tais benefícios. Isto porque nem toda característica do homem pode ser levada em consideração como justificativa para a edição de lei que tratasse diferentemente os desiguais. Segundo Leila Pinheiro Bellintanti houve doutrinadores que chegaram a, com base nisso, asseverar que o princípio da igualdade seria uma fórmula vazia, pois qualquer característica individual do homem poderia servir de justificativa para a adoção de tratamentos diferenciados, o que contrariaria a essência do princípio da igualdade ${ }^{115}$.

Segundo a mesma autora, o princípio da igualdade pode atualmente ser encontrado na quase totalidade das constituições vigentes, sob duas distintas dimensões que englobam os inúmeros significados por ele auferidos ao longo de sua evolução. São elas a concepção liberal, que reflete a idéia de que todos os cidadãos estão em igual posição perante a lei geral e abstrata, independentemente do seu status; a democrática, revelando-se na expressa proibição de discriminações e a social, impondo a eliminação de desigualdades fáticas, com o escopo de atingir uma igualdade real entre os indivíduos ${ }^{116}$.

Analisando-as conjuntamente, o que se pode depreender é que atualmente já não se parte do pressuposto de que haveria uma igualdade plena entre todos os homens, mas sim do postulado de que estes são diferentes entre si, possuindo cada um sua própria individualidade, suas próprias características, capacidades e valores ${ }^{117}$, o que leva Leila Pinheiro Bellintani a concluir que o reconhecimento dessas diversidades implicaria constante persecução do ideal de justiça, a ser realizado através de um princípio da igualdade em que as diferenças sejam

\footnotetext{
${ }^{114}$ Ibidem, p. 13.

115 Ibidem, p. 13.

${ }^{116}$ Ibidem, p. 16.
} 
verificadas e respeitadas, mas que, ao mesmo tempo, não possam servir de justificativa para discriminações sociais ${ }^{118}$.

Esta opinião assemelha-se a de Norberto Bobbio, que também discorda da identificação plena entre entre igualdade e justiça, feita por Aristóteles. Embora reconheça que "o conceito e o valor da igualdade mal se distinguem do conceito e do valor da justiça na maioria de suas acepções, tanto que a expressão liberdade e justiça é freqüentemente utilizada como equivalente da expressão liberdade e igualdade"119, ele conclui asseverando que a expressão mais correta para se conjugar os dois valores supremos da vida civil, é liberdade e justiça e não liberdade e igualdade, já que a igualdade não é por si mesma um valor, mas o é somente na medida em que seja uma condição necessária, ainda que não suficiente, daquela harmonia do todo, daquele ordenamento das partes, daquele equilíbrio interno de um sistema que mereça o nome de justo. Arremata ainda que justiça é um ideal e igualdade um fato ${ }^{120}$.

Em todo caso reconhece que a igualdade permeia os conceitos aristotélicos de justiça comutativa e de justiça distributiva tão presentes até hoje porquanto aquela parta de uma relação bilateral e recíproca entre as partes, na qual o problema da igualdade se apresenta como problema de equivalência de coisas (o que se dá deve ser equivalente ao que se tem); e esta de uma relação multilateral e unidirecional, em que a igualdade surge como um problema de equiparação de pessoas. Esta última, também chamada justiça atributiva, não se mostra possível de especificação ulterior, tantas e tão imprevisíveis são as situações nas quais se exige uma equalização nas relações entre indivíduos ${ }^{121}$.

O grande problema em se associar incondicionalmente critérios de igualdade à noção de justiça reside do fato de que há situações em que o justo corresponde ao tratamento igualitário e outras em que justo consiste justamente no tratamento desigual. Explica-se. Ao basear, por exemplo, a definição de justiça na

\footnotetext{
117 Ibidem, p. 16.

${ }^{118}$ Ibidem, p. 17.

${ }^{119}$ BOBBIO, Norberto. Op. cit., p.14

${ }^{120}$ Ibidem, p. 16.

${ }^{121}$ Ibidem, p. 17.
} 
conhecida máxima aristotélica, segundo a qual se devem tratar os iguais de modo igual e os desiguais de modo desigual, não se esclarece em definitivo o que é justo e o que é injusto. Apenas se modifica o foco do problema. Ao invés de se questionar o que é justo, passa-se a questionar se a igualdade em questão é justa ou injusta, ou se a desigualdade promove justiça ou acentua a injustiça ${ }^{122}$. Celso Antônio Bandeira de Mello, ao se debruçar sobre o conteúdo jurídico do princípio da igualdade, destacou as seguintes reflexões:

A dizer: o que permite radicalizar alguns sob a rubrica de iguais e outros sob a rubrica de desiguais? Em suma: qual o critério legitimamente manipulável - sem agravos à isonomia - que autoriza distinguir pessoas e situações em grupos apartados para fins de tratamentos jurídicos diversos? Afinal, que espécie de igualdade veda e que tipo de desigualdade faculta a discriminação de situações e de pessoas, sem quebra e agressão aos objetivos transfundidos no princípio constitucional da isonomia? ${ }^{123}$

Ademais, como observa o referido autor, "não há duas situações tão iguais que não possam ser distinguidas, assim como não há duas situações tão distintas que não possuam algum denominador comum em função de que se possa pacificá-las" $" 124$.

Em suma, tratar igualmente os iguais e desigualmente os desiguais, consiste em importante ponto de partida, mas não soluciona as discussões envolvendo o princípio da igualdade. É preciso definir quem são os iguais que devem receber mesmo tratamento e quem são os desiguais que devem receber tratamento diferente. Somente assim, ter-se-á o postulado da igualdade a serviço de uma concepção efetiva de justiça.

\footnotetext{
${ }^{122}$ Segundo Bobbio: "Duas coisas ou duas pessoas podem ser iguais ou equalizadas sob muitos aspectos: a igualdade entre elas, ou sua equalização só tem a ver com a justiça quanto corresponde a um determinado critério (que é chamado critério de justiça), com base no qual se estabelece qual dos aspectos deva ser considerado relevante para o fim de distinguir entre uma igualdade desejável e uma igualdade indesejável" (Ibidem, p. 18.)

${ }^{123}$ MELLO, Celso Antonio Bandeira de. O conteúdo jurídico do princípio da igualdade. $3^{\mathrm{a}}$ edição, $14^{\mathrm{a}}$ tiragem. São Paulo: 2006, p. 11.

${ }^{124}$ Ibidem, p. 42.
} 


\subsection{CONTRAPOSIÇÃO ENTRE IGUALDADE E LIBERDADE.}

Como salienta Lucyla Tellez Merino, na promoção da dignidade humana, o valor liberdade deve, necessariamente, ser conjugado com o valor igualdade. São princípios éticos que se complementam e se integram. A liberdade não sobrevive sem a igualdade, lógica que se encontra também no sentido inverso ${ }^{125}$. Arremata ainda que a ética da liberdade, como exaustivamente pontuado no decorrer deste trabalho para alcançar a finalidade do homem como fim em si mesmo, só poderá ser imaginada conjugada, sempre, com a ética da igualdade e vice-versa, pois são forças que se equilibram e respaldam a paz social com dignidade humana ${ }^{126}$.

Comungando da mesma opinião, Norberto Bobbio inicia o seu estudo sobre a igualdade destacando a estreita relação existente entre esta e a liberdade. Segundo o jusfilósofo italiano estes dois valores remetem um ao outro no pensamento político e na história, enraizando-se ambos na consideração do homem como pessoa humana, ser distinto de todos os outros seres vivos. Diferem-se, segundo o autor peninsular, na medida em que liberdade indica um estado enquanto igualdade indica uma relação. Melhor esclarecendo, o homem para ser considerado pessoa "deve ser, enquanto indivíduo, em sua singularidade, livre; enquanto ser social, deve estar com os demais indivíduos numa relação de igualdade" ${ }^{\text {127. }}$.

Trata de esclarecer o autor italiano que estes dois valores, não obstante servirem de fundamento para a democracia e serem por demais desejáveis, não são absolutos, comportando limitações justificadas ${ }^{128}$. Destaca ainda

\footnotetext{
${ }^{125}$ MERINO, Lucyla Tellez. Op. cit., p 219.

${ }^{126}$ Ibidem, p 222. Ao final, Merino enaltece a simbiose que deve haver entre os dois princípios em questão, aduzindo que: "A melhor leitura - sobre a simbiose em que se inserem os conceitos de liberdade e igualdade - é a de que só a liberdade não provoca maior igualdade, nem só a igualdade provoca maior liberdade, e sim ambas, juntas, têm o condão de provocar o desenvolvimento uma da outra (Ibidem, p. 222)".

${ }^{127}$ BOBBIO, Norberto. Op. cit., p.7.

${ }^{128}$ Apesar de sua desejabilidade geral, liberdade e igualdade não são valores absolutos. Não há princípio abstrato que não admita exceções em sua aplicação. A diferença entre regra e exceção está no fato de que a exceção deve ser justificada. Onde a liberdade é igualdade, deve ser justificado o tratamento desigual. Mas o ponto de partida também pode ser oposto, como na escola ou num quartel, onde a regra é a disciplina e a liberdade é a exceção. Decidir o que é mais normal, se a liberdade ou a disciplina, a igualdade ou a hierarquia, não é algo que se possa fazer de uma vez por todas. Liberdade e igualdade são
} 
que a dificuldade em estabelecer um significado descritivo de igualdade residiria, sobretudo, em sua indeterminação. Para ele dizer que dois entes são iguais sem nenhuma outra determinação nada significa em linguagem política, sendo necessário que se especifique com que entes estamos tratando e com relação a que são iguais. Em outras palavras, seria preciso responder a duas perguntas: a) igualdade entre quem?; e b) igualdade em quê${ }^{129}$ ?

A igualdade, ao contrário da liberdade, não seria uma qualidade ou propriedade da pessoa, mas um tipo de relação formal que pode ser preenchido pelos mais diversos conteúdos. Assim, diferente do conceito e do valor da liberdade, o conceito e o valor da igualdade pressupõe, para sua aplicação, a presunção de uma pluralidade de entes cabendo estabelecer que tipo de relação há entre eles ${ }^{130}$.

José Afonso da Silva destaca em tom crítico que o direito de igualdade não tem merecido tantos discursos como a liberdade, em razão de o tema não interessar às classes dominantes ${ }^{131}$.

Segundo Daniela Izzi, o paradigma igualitário em torno do qual o direito do trabalho se construiu começa a apresentar sinais de crise, instado pela agressividade sem precedentes da tendência diferenciadora do processo social vigente. Esta tendência alicerça-se, sobretudo, nas profundas transformações ocorridas no sistema de produção e no método de trabalho praticado com intensidade crescente em direção a multiplicação dos esquemas contratuais e uma mais flexível articulação das normas de proteção ao trabalho, e a repropozição do modelo do individualismo liberal, que insiste na atitude do sujeito individual em se autodeterminar, em substituição à proteção paternalística da lei e da contratação coletiva. Outro fundamento para a crise do princípio igualitário é o emergente multiculturalismo, que

mais normais do que disciplina e hierarquia somente em sentido normativo, no universo do dever ser (Ibidem, p. 8.).

${ }^{129}$ BOBBIO, Norberto. Op. cit., pp.11/12.

${ }^{130}$ Ibidem, pp. 11/13.

131 "É que a igualdade constitui o signo fundamental da democracia. Não admite os privilégios e distinções que um regime simplesmente liberal consagra. Por isso é que a burguesia, cônscia de seu privilégio de classe, jamais postulou um regime de igualdade tanto quanto reivindicara o de liberdade. É que um regime de igualdade contraria seus interesses e dá à liberdade sentido material que não se harmoniza com o domínio de classe em que assenta a democracia liberal burguesa" (SILVA, José Afonso da. Curso de direito constitucional positivo. $22^{a}$ edição. São Paulo: Malheiros, 2003, p. 210). 
aposta no reconhecimento das características identitárias dos grupos sociais, não estando dispostas a sacrificar suas próprias peculiaridades sob o altar da plena integração ${ }^{132}$.

Entre os que entendem que o princípio igualitário encontra-se em crise, há Manuel Garcia Fernandez, que, ao prefaciar a obra de Luis Gabriel Martínez Rocamora, assevera que a exacerbação da igualdade pode acaba sendo extremamente gravosa por paralisar as muitas energias que as minorias são capazes de por em marcha, justificando assim a conclusão de que entre os europeus são muitas as vozes que defendem que a liberdade (e, conseqüentemente, as diferenças) deve recuperar os espaços a que tem direito em uma sociedade altamente desenvolvida ${ }^{133}$.

Felizmente ainda há vozes se insurgindo contra esta tendência que apregoa nova modificação nas relações entre igualdade e liberdade individual através de uma relativização daquela para aumentar o espaço ${ }^{134}$. Segundo Daniela Izzi, se o direito do trabalho renuncia ao princípio da igualdade substancial que lhe confere sua função basilar de corrigir a disparidade existente, seja entre as

${ }^{132}$ Il paradigma egualitário attorno al quale il diritto del lavoro è andato via constituendosi comincia a manifestare segni di crisi, incalzato con un"aggressività priva di precedenti dalle tendenze spicatamente differenziatrici espresse dai processi sociali in atto. Vari, in particolare, sono i fronti dell"attacco sferrato negli anni recenti all"eguaglianza: non solo, difatti, le profonde trasformazioni intervenute nei sistemi di produzione e nei metodi di lavoro esercitano spinte d'intensità crescente verso la moltiplicazione degli schemi contrattuali e una più flessibile articolazione delle regole lavoristiche; ma contributi non trascurabili provengono, anche, dalla riproposizione del modello dell'individualismo liberale, che insiste sull'attitudine dei singoli soggetti ad $<<$ autodeterminarsi al riparo della protezione paternalistica della legge e della contrattazione collettiva $>>$, e, sotto altro aspetto, dall'emergente multiculturalismo, che punta al riconoscimento delle caratteristiche identitarie di gruppi sociali non disposti a sacrificare le proprie preculiarità sull'altare della piena integrazione. (IZZI, Daniela. Eguaglianza e differenze nei rapporti di lavoro: il diritto antidiscriminatorio tra genere e fattori di rischio emergenti. Napoli, Casa Editrice Jovene, 2005, p. 2).

${ }^{133}$ Sucede que, al final, la igualdad acaba siendo extremamente gravosa; y, por gravosa, paraliza las muchas energías que las minorías son capaces de poner en marcha. Ha ocurrido así en toda la historia de la humanidad (por citar dos ejemplos célebres: la presión fiscal y la terrible capitación que la siguió fueron causas principales del hundimiento del Império Romano; las cargas fiscales esquilmaron decisivamente la potencia de Castilla y precipitaron la decadencia de la Corona de España) y parece que empieza a ocurrir ahora frente a poderes económicos emergentes en otros lugares del mundo. Por eso, entre nosotros (los europeus) son muchas las voces que piden más flexibilidad, menos regulación y, sobre todo, una cosa pública mucho menos aparatosa; digo yo, en otros términos, que la libertad (y, consiguientemente, as diferencias) recupere los espacios a que tiene derecho en una sociedad altamente desarollada. (In: ROCAMORA, Luis Gabriel Martínez. Decisiones empresariales y princípio de igualdad. Barcelona: Cedecs Editorial S.L., 1998, p. 21).

${ }^{134}$ L'insistente accento posto sull'esigenza di "relativizzare" l'eguaglianza per far spacio alla libertà, anziutto, nell misura in cui sottende un'implicita contrapposizione tra i suddetti valori, costituisce l'ennesimo esempio di ricadura in quel ricorrente $<<$ errore categoriale $>>$. (Ibidem, p. 4). 
partes do contrato de trabalho, seja internamente na coletividade de trabalhadores, ele perde o significado de sua existência ${ }^{135}$.

A crítica da autora italiana é perfeita. Não se pode, sob o falacioso argumento econômico de adequação da proteção trabalhista à realidade do mercado, admitir que o interesse meramente financeiro do empregador se sobreponha ao direito do empregado à igualdade, sob pena de se estar desconsiderando o princípio da dignidade da pessoa humana que norteia a grande maioria dos ordenamentos jurídicos ocidentais. Imaginar haver chegado a hora de o trabalhador se libertar dos grilhões que o acorrentam ao regime protecionista, em um regime econômico com altíssima concentração de renda e desigualdades sociais abissais, consiste em ignorar o contexto socioeconômico atual. Não se pode olvidar que o direito do trabalho foi desenvolvido não com o intuito de assegurar liberdade para as partes, mas sim de reduzir juridicamente as desigualdades que materialmente existem entre empregador e empregado. É natural, portanto, que em matéria de direito do trabalho o princípio da igualdade sobreponha-se ao da liberdade.

Sendo certo, como visto no item anterior, que a solução para o conflito entre direitos e postulados deve ser encontrada a partir do conceito de dignidade da pessoa humana, há que se concordar que em havendo conflito entre liberdade e igualdade em matéria de relação de trabalho, é este o postulado que deve prevalecer. Afinal, ele se aproxima muito mais do referido conceito do que aquele. Esta é a lição que se tira dos ensinamentos de Ingo Wolfgang Sarlet, segundo quem o princípio da dignidade da pessoa humana pode ser relativizado em homenagem à igual dignidade de todos os seres humanos ${ }^{136}$

\footnotetext{
${ }^{135}$ Se il diritto del lavoro rinunciasse a quell'intimo legame col principio di eguaglianza sostanziale che gli conferisce la basilare funzione di correzione delle disparità esistenti sia tra le parti del contratto di lavoro (cioè nei rapporti verticale) che all'interno della collettività dei lavoratori (cioè a livello orizzontale), verrebbe inevitabilmente meno, insieme alla ragione della caratteristica inderogabilità dei suoi precetti, il significatto stesso della sua esistenza (Ibidem, p.3)

${ }^{136}$ Em suas palavras: "Mesmo prevalecendo em face de todos os demais princípios (e regras) do ordenamento, não há como afastar - como ainda teremos oportunidade de discutir - a necessária relativização (ou, se preferirmos, convivência harmônica) do princípio da dignidade em homenagem à igual dignidade de todos os seres humanos”. (SARLET, Ingo Wolfgang. Dignidade..op. cit., p. 76.).
} 
Sobretudo quando a discussão refere-se à liberdade de contratar, de disciplinar a atividade econômica e de dispensar do empregador, e o direito do empregado de ser tratado igualmente a seus pares.

É preciso cautela para não se incorrer nos mesmo equívocos do passado. Como salienta Lucyla Tellez Merino, "não se deve recair no mesmo equívoco em que incidiu a Revolução Francesa, de mitigar a igualdade como valor e princípio basilar humanista, sob pena da desarvorada busca do equilíbrio social" 137 .

\subsection{DIFERENTES CONCEPÇÕES DE IGUALDADE}

Segundo o Cardeal Dom Paulo Evaristo Arns, o grande problema para a vigência dos direitos humanos no Brasil, além da situação concreta do país, é o da mentalidade brasileira, que não tem a menor noção do que seja igualdade ${ }^{138}$. A crítica é de fato acurada e procedente. Há que se ressalvar, sem tentar justificar a ignorância do povo brasileiro acerca do tema, que definir igualdade não é uma tarefa das mais simples ${ }^{139}$. Trata-se de um conceito aberto ao qual já foram atribuídas muitas e diversas concepções.

No direito estrangeiro, faz-se distinção entre o princípio da igualdade perante a lei e o da igualdade na lei. O primeiro entendido como a obrigação de aplicar as normas jurídicas gerais aos casos concretos, na conformidade com o que elas estabelecem, mesmo se delas resultar uma discriminação. O segundo, visto como o postulado que exige que, nas normas jurídicas, não haja distinções que não sejam autorizadas pela própria constituição. Em outras palavras, para o referido constitucionalista, a igualdade perante a lei seria uma exigência feita a todos aqueles

137 MERINO, Lucylla Tellez. Op. cit., p. 222.

138 ARNS, Cardeal Dom Paulo Evaristo. Para que todos tenham vida. In: Discriminação: estudos.Viana, Márcio Túlio e Renault, Luiz Otávio Linhares (coord). São Paulo: LTr, 2000, p. 18. 
que aplicam as normas jurídicas gerais aos casos concretos, ao passo que a igualdade na lei seria uma exigência dirigida tanto àqueles que criam as normas jurídicas gerais quanto àqueles que as aplicam aos casos $\operatorname{concretos}^{140}$.

José Afonso da Silva entende desnecessária esta distinção, pelo menos no que se refere ao direito brasileiro, na medida em que a doutrina e a jurisprudência entendem há muito que a expressão princípio da igualdade denota tanto o que os estrangeiros denominam igualdade perante a lei quanto o que chamam igualdade na lei ${ }^{141}$. É o que comprova o seguinte pronunciamento pelo Supremo Tribunal Federal ressaltando não tratar a questão de dois princípios distintos, mas de duas vertentes do mesmo princípio:

Aplicabilidade plena do princípio da isonomia. Igualdade na lei e perante a lei: O princípio da isonomia é auto-aplicável deve ser considerado sob duplo aspecto: a) o da igualdade na lei; b) o da igualdade perante a lei. A igualdade na lei é exigência dirigida ao legislador, que, no processo de formação da norma, não poderá incluir fatores de discriminação que rompam com a ordem isonômica. A igualdade perante a lei pressupõe a lei já elaborada e dirigese aos demais Poderes, que, ao aplicá-la, não poderão subordiná-la a critérios que ensejem tratamento seletivo ou discriminatório (STF, RDA 183/143) ${ }^{142}$.

Outra distinção comumente encontrada na doutrina é a formulada entre igualdade material e igualdade formal. Como leciona Vera Lúcia Carlos, a igualdade formal pode ser considerada o direito de que dispõe todo cidadão de não ser tratado desigualmente pela lei senão em decorrência da adoção de critérios relacionados ou pelo menos não vedados pela ordem constitucional. Em outras palavras, consiste no direito consagrado aos seres da mesma espécie, de uma mesma

\footnotetext{
139 Como salienta Norberto Bobbio "se a determinação do que deve ser entendido por igualdade substancial não levantasse tantas questões, não teríamos conhecido tantas formas diversas de doutrinas igualitárias, freqüentemente umas em conflitos com as outras".(Op. cit., p.35).

${ }^{140}$ SILVA, José Afonso da. Curso...op. cit., p. 214. "Parece interessante, neste momento, tratar da distinção que alguns doutrinadores costumam estabelecer entre as expressões 'igualdade na lei' e 'igualdade perante a lei'. Para esses doutrinadores, a primeira expressão é voltada para o legislador, proibindo a elaboração de leis que estabeleçam desigualdades, enquanto a segunda é direcionada para os operadores do direito, que não podem utilizar critérios discriminatórios”. (CARLOS, Vera Lúcia. Discriminação nas relações de trabalho. São Paulo: Método, 2004, p. 23)

${ }^{141}$ Ibidem, p. 23.

${ }^{142}$ In: BARROSO, Luís Roberto. Constituição da República Federativa do Brasil anotada. $5^{\mathrm{a}}$ edição.
} São Paulo: Saraiva, 2006, p. 39. 
categoria essencial, de serem tratados da mesma maneira ${ }^{143}$. Guilherme Machado Dray, por sua vez, pondera que a idéia de igualdade, nesta esteira, significa que todos os cidadãos são iguais perante a lei, pelo que a lei deve ser igual para todos, sem distinções de privilégios, consubstanciando-se tal obrigatoriedade nas características da generalidade e abstração do ato normativo. Trata-se, como já visto, de uma concepção associada ao constitucionalismo liberal, assentado na idéia de que todos os homens são iguais perante a lei, isto é, na relação que mantém com o Poder, entendido este como a única realidade susceptível de ameaçar a liberdade individual e cada pessoa ${ }^{144}$.

Igualdade material, (também denominada efetiva, real, concreta), por sua vez, consiste na busca da igualdade de fato na vida econômica e social $^{145}$. Este conceito surge como decorrência das críticas dirigidas à concepção liberal de igualdade. Segundo Guilherme Machado Dray, esta concepção do princípio da igualdade visa atuar no sentido do tratamento diferenciado de situações concretas dessemelhantes, visando evitar o aprofundamento das desigualdades fáticas realmente existentes $^{146}$.

Norberto Bobbio, por sua vez, refere-se à distinção entre igualdade de fato, igualdade formal ou jurídica e igualdade de oportunidades. Segundo o renomado jusfilósofo italiano, por igualdade de fato, termo utilizado em contraposição à igualdade real ou substancial por ser o utilizado na constituição de seu país, entende-se a igualdade com relação aos bens materiais, ou igualdade econômica. O grande óbice na efetivação desta forma igualdade, segundo ele, reside no fato de não ser nada claro determinar quais sejam as formas e os modos específicos através dos quais se supõe que essa igualdade possa ser pretendida e realizada. É como salienta o doutrinador italiano:

\footnotetext{
${ }^{143}$ CARLOS, Vera Lúcia. Op. cit., p. 22.

${ }^{144}$ DRAY, Guilherme Machado. Op. cit., p.20.

${ }^{145}$ CARLOS, Vera Lúcia. Op. cit., p. 22.

${ }^{146}$ Em suas palavras: "Por esta razão, o conceito material de igualdade, emergente do Estado Social de Direito, vai actuar no sentido da unificação do princípio da igualdade enquanto realidade aplicável quer aos agentes de aplicação do direito, quer ao próprio legislador, relativamente ao qual se passa a admitir uma produção legislativa que contemple a existência de casos particulares. A igualdade material vem assim admitir o tratamento diferenciado de situações fáticas desiguais, tendo em vista, no essencial, a proteção e a defesa dos interesses dos indivíduos social e economicamente desfavorecidos, como forma de persecução de um equilíbrio social e econômico" (DRAY, Guilherme Machado. Op. cit., p.21).
} 
Igualdade com relação aos bens materiais. Mas que bens? E por que não também aos bens espirituais ou culturais? Se se definirem os bens com relação às necessidades que eles tendem a satisfazer, a questão da determinação do que é ou do que não é um bem remete à questão da determinação de quais são as necessidades dignas de serem satisfeitas e em relação às quais se considera justo que os homens sejam iguais. Todas as necessidades ou apenas algumas? E, dado que não parece possível responder todas - e nem mesmo o mais conseqüente e fanático igualitário jamais deu tal resposta - , então surge outra pergunta: qual o critério com base no qual é possível distinguir entre necessidades merecedoras e não merecedoras de satisfação? Seria, porventura, o critério da utilidade social, segundo o qual se distinguem as necessidades entre socialmente úteis e socialmente nocivas? Ou o critério, ainda mais vago, da correspondência à natureza, pelo qual se distinguem as necessidades entre naturais e artificiais, espontâneas e provocadas pelos produtores de bens de consumo ${ }^{147}$ ?

Como destaca Bobbio, nem a resposta a essas questões solucionaria o problema. Afinal, uma vez determinada a natureza dos bens com relação aos quais os homens deveriam ser iguais, ainda assim o problema da igualdade não estaria resolvido, porquanto seria imprescindível estabelecer os modos através dos quais os homens entram e permanecem em relação com esses bens. Neste ponto, precisar-se-ia definir se é necessária a posse ou basta o uso, se o gozo é suficiente ou se a disponibilidade é imprescindível, entre outros questionamentos que surgem ${ }^{148}$.

Ainda que superado este ponto, novo e relevante questionamento se põe. É preciso definir se a igualdade invocada será absoluta ou relativa. Ou, como indaga o renomado jusfilósofo italiano, "os bens a serem distribuídos serão distribuídos segundo a fórmula cada um em partes iguais, ou segundo a fórmula a cada um na proporção de...? ${ }^{149}$ ".

Finalizando a sua crítica à concepção de igualdade de fato, Bobbio destaca que o caráter igualitário de uma doutrina não está na exigência de que todos sejam tratados de modo igual com relação aos bens relevantes, mas que o

\footnotetext{
${ }^{147}$ BOBBIO, Norberto. Op. cit., p.34

${ }^{148}$ Ibidem, p.34

${ }^{149}$ Ibidem, p.34
} 
critério com base no qual esses bens são distribuídos, seja ele mesmo o mais igualitário possível $^{150}$.

Por igualdade nos direitos, entende Bobbio o igual gozo, por parte dos cidadãos, de alguns direitos fundamentais constitucionalmente assegurados. Segundo ele esta teria sido a fórmula consagrada na Declaração de Direitos do Homem e do Cidadão de 1789, onde restou consignado que "Os homens nascem e permanecem livres e iguais nos direitos", e na Declaração Universal dos Direito do Homem, de 1948, onde se estatui que "Todos os homens nascem livres e iguais em direitos e obrigações". Em sua opinião igualdade jurídica significa algo mais do que a simples igualdade perante a lei. Fundamenta esta conclusão ponderando que a igualdade perante a lei nada mais seria do que uma forma específica e historicamente determinada de igualdade de direito ou dos direitos, enquanto a igualdade nos direitos compreenderia, além do direito de ser considerado igual perante a lei, todos os direitos fundamentais enumerados numa Constituição, tais como os direitos civis e políticos ${ }^{151}$.

Bobbio cataloga ainda uma outra forma de igualdade, chamada igualdade jurídica. Segundo seus ensinamentos a igualdade nos direitos teria um âmbito mais amplo que o da igualdade perante a lei, como já salientado, enquanto a igualdade jurídica apresentaria um âmbito mais restrito. Segundo Bobbio o âmbito da igualdade jurídica seria mais restrito do que o da igualdade perante a lei, porquanto o alvo desta seria a sociedade de estamentos, enquanto o daquela seria a sociedade escravocrata, em que nem todos os seus membros teriam personalidade jurídica $\operatorname{assegurada}^{152}$.

Modernamente, há uma tendência em se conceber a idéia de igualdade como igualdade de oportunidades. Para Guilherme Machado Dray, esta idéia consiste na evolução da concepção material de igualdade e busca a abolição das desigualdades fáticas, pressupondo a promoção de medidas corretivas das desigualdades existentes através de discriminações positivas. Tratar-se-ia, segundo seu entendimento, de conceber o princípio da igualdade como uma concretização do ideal

\footnotetext{
${ }^{150}$ Ibidem, p.34

${ }^{151}$ BOBBIO, Norberto. Ibidem, pp.29/30

${ }^{152}$ BOBBIO, Norberto. Ibidem, pp. 30.
} 
de justiça social, como um ponto de chegada e não como um ponto de partida, como uma forma real assente na eliminação das desigualdades econômicas, sociais e culturais $^{153}$.

Bobbio critica esta concepção do princípio da igualdade por considerar que ela não apresenta nada de particularmente novo, não passando da aplicação da regra de justiça a uma situação na qual existem várias pessoas em competição para obtenção de um objetivo único que somente será alcançado por uma delas. Arremata ainda o autor italiano que o que mais faz desse princípio um princípio inovador nos Estados social e economicamente avançados é o fato de ele ter se difundido grandemente como conseqüência do predomínio de uma concepção conflitualista global da sociedade, segundo a qual toda a vida social seria uma grande competição para obtenção de bens escassos. Para Bobbio, o princípio da igualdade de oportunidades, que varia de sociedade para sociedade, busca "colocar todos os membros daquela determinada sociedade na condição de participar da competição pela vida, ou pela conquista do que é vitalmente mais significativo, a partir de posições iguais ${ }^{154,}$.

A crítica mais contundente apresentada pelo referido autor a esta concepção de igualdade reside justamente na constatação de que para colocar indivíduos desiguais por nascimento nas mesmas condições de vida, pode ser necessário criar favorecimento aos mais fracos para torná-los em condição de competir, o que acabaria tornando necessário que seja utilizado um tratamento diferenciado como instrumento para compensar uma desigualdade anterior ${ }^{155}$.

Críticas a parte, esta é uma das concepções de igualdade que irá importar ao presente estudo. Com efeito, uma das questões que se aqui se pretende discutir é o direito do cidadão de, na ausência de empregos compatíveis com a sua qualificação profissional, disputar posto de trabalho que não a

153 DRAY, Guilherme Machado. Op. cit., pp.20/21. O referido autor destaca ainda que "a noção de 'igualdade de oportunidades' surge como um ponto de enontro entre duas grandes tradições jurídicoideológicas existentes a propósito da igualdade: a liberal, que ao assentar na neutralidade do Estado, concebe a igualdade de oportunidades como uma igualdade de condições jurídicas independentemente da existência de desigualdades de meios factuais; e a social, que assenta no restabelecimento da própria igualdade factual, como condição necessária para a promoção de uma igualdade real"(Ibidem, p. 89).

${ }^{154}$ BOBBIO, Norberto. Op. cit., pp.30/32. 
requeiram, com pessoas que não possuem a mesma formação. Também se irá discutir o direito do empregado mais qualificado à igual oportunidade de permanecer no emprego, a despeito de seu salário superior aumentar os custos para o empregador.

Outra diferenciação que merece destaque seria entre princípio da igualdade e princípio da não-discriminação. Não há na doutrina brasileira um consenso quanto ao fato deste ser desdobramento daquele, ou um outro princípio com ele relacionado. Filiada à primeira corrente doutrinária, Vera Lúcia Carlos assevera não tratar o postulado da não-discriminação propriamente de um princípio, mas sim de um desdobramento do princípio da igualdade ${ }^{156}$. Posicionando-se em sentido contrário, Christiani Marques defende que não obstante o princípio da não discriminação surja como decorrência da isonomia, consiste aquele em uma especialização desta. Outrossim, assume, em virtude de sua importância, posição de princípio, embora vinculado e englobado pelo princípio mais abrangente, o da igualdade $^{157}$. Entendimento que parece ser partilhado por Guilherme Machado Dray, segundo quem "falar do princípio da igualdade envolve, necessariamente, a abordagem do tema o princípio da não discriminação, que surge inevitavelmente como uma sua concretização ou reflexo" ${ }^{\prime 158}$.

Não obstante a relevância dos ensinamentos acima transcritos como fomentadores de discussões acerca da abrangência real do princípio da igualdade, para os fins objetivados pelo presente trabalho suficiente será a distinção entre igualdade formal e igualdade material, considerando-se ainda o imperativo de não-discriminação como um mero desdobramento do princípio da igualdade e não como um princípio autônomo. Afinal, como visto na análise histórica acima efetuada, a não discriminação surge como uma decorrência natural da evolução da concepção de direito à igualdade.

Direcionando, outrossim, a análise para a distinção entre igualdade formal e igualdade material, valiosas são as lições de José Afonso da Silva, segundo quem diferentemente do estabelecido em todas as suas antecessoras

\footnotetext{
${ }^{155}$ BOBBIO, Norberto. Ibidem, pp.30/32.

${ }^{156}$ CARLOS, Vera Lúcia. Ibidem, p. 19.

${ }^{157}$ MARQUES, Christiani. Ibidem, p. 167.
} 
desde a época imperial, a isonomia estatuída na Constituição Brasileira de 1988 não deve ser interpretada apenas como isonomia formal. Para o referido autor, o art. $5^{\circ}$, caput da Carta Magna há que ser aferido com outras normas constitucionais e, especialmente, com as exigências da justiça social, objetivo da ordem econômica e da ordem social. Para ele o dispositivo referido consagra a isonomia formal, para diferenciá-lo da isonomia material, traduzida na no art. $7^{\circ}$, XXX e XXXI. E conclui asseverando que a Constituição procura aproximar os dois tipos de isonomia, uma vez que não se limita a enunciar a igualdade perante a lei, mencionando também igualdade entre os homens e mulheres e acrescentando vedações a distinções de qualquer natureza e qualquer forma de discriminação ${ }^{159}$.

No mesmo sentido é o magistério de Vera Lúcia Carlos, segundo quem o legislador constituinte brasileiro pugnou não só pela igualdade formal, mas também pela igualdade material, na medida em que não se limitou ao simples enunciado da igualdade perante a lei, mas foi além, demonstrando, em diversos dispositivos, preocupação com a desigualdade existente em nosso país, fixando mecanismos que possibilitem assegurar a igualdade real entre os indivíduos. Ainda assim, a referida autora também minora a distinção em questão por entender que ela só se justifica, nos dias de hoje, ao se fazer uma abordagem histórica, porquanto há unanimidade entre os doutrinadores quanto ao fato da isonomia adotada em nosso sistema jurídico ser a material ${ }^{160}$.

\subsection{PRINCÍPIO DA IGUALDADE, APLICAÇÃO NO DIREITO DO TRABALHO E EFICÁCIA HORIZONTAL DOS DIREITOS FUNDAMENTAIS.}

Em sua monografia sobre o tema, Celso Antônio Bandeira de Mello destaca que o preceito magno da igualdade volta-se tanto para o

\footnotetext{
${ }^{158}$ DRAY, Guilherme Machado. Ibidem, p.97.

${ }^{159}$ SILVA, José Afonso da. Curso... Ibidem, pp. 213/214.
} 
aplicador quanto para o próprio legislador. Em seu entendimento, não só perante a norma posta se nivelam os indivíduos, mas a própria edição dela se sujeita ao dever de dispensar tratamento equânime às pessoas ${ }^{161}$.

Guilherme Machado Dray, ao se pronunciar sobre como entende que deve ser a atuação do Estado, afirma que as obrigações decorrentes do princípio da igualdade não são, em uma análise preliminar, obrigações diretas, no sentido em que do princípio da igualdade não decorre diretamente uma obrigação de ação ou de omissão. Segundo o seu magistério, excetuando-se os casos em que o Estado esteja vinculado à persecução de uma igualdade real, assente na promoção de discriminações positivas, do princípio da igualdade decorre, apenas, a exigência de que quando os poderes públicos atuem, o façam de acordo com este princípio, e de que quando o Estado legisle, o faça de acordo com o princípio em apreço ${ }^{162}$.

Outra importante lição do renomado autor português refere-se ao fato do postulado em questão ser extremamente abstrato e, portanto, somente poder definido no caso concreto. Trata-se, em sua opinião, de uma cláusula geral que não elucida o que deve ser tratado de forma idêntica ou diferente e não aponta antecipadamente qual atividade ou qualidade do sujeito seria necessária para a sua incidência ${ }^{163}$.

A concepção liberal dos direitos fundamentais acreditava que na sociedade civil as relações entre os indivíduos eram tendencialmente iguais devendo sua atuação ser pautada pela vontade de cada qual, razão pela qual

\footnotetext{
${ }^{160}$ CARLOS, Vera Lúcia. Ibidem, p. 165.

${ }^{161}$ MELLO, Celso Antonio Bandeira de. Ibidem, p. 9.

${ }^{162}$ DRAY, Guilherme Machado. Ibidem, p.125.

163 "Pelo contrário, o interesse subjacente ao princípio da igualdade, pelo menos aparentemente, não é directo, mas sim derivado, e aquilo que dele se extrai só é passível de concretização caso a caso, perante situações concretas. O interesse que dele decorre, por outro lado, não é um interesse absoluto, como sucede com os direitos fundamentais à dignidade, à liberdade de expressão ou à propriedade, mas sim um interesse necessariamente relativo. Por isso, o princípio da igualdade perante a lei não pode deixar de figurar como um princípio que a priori é invariavelmente abstracto, constituindo uma "cláusula geral cujo campo normativo não está concretamente descrito". Ele não nos elucida a propósito daquilo que deve ser tratado de forma idêntica ou diferente; ele não aponta qualquer actividade ou qualidade do sujeito e o seu conteúdo concreto só pode ser discernido quando em presença de um determinado caso concreto; ele determina uma certa forma de tratar a realidade mas não aponta, porém, qual a realidade de que está a falar" (DRAY, Guilherme Machado. Ibidem, p.126.).
} 
apregoava que só o Estado podia ameaçar as liberdades individuais dos particulares, o que tornava a aplicação do princípio da igualdade, ao nível da sociedade civil despicienda constituindo-se em entrave à liberdade individual de cada um. Entendia-se que deveria prevalecer nestes casos a autonomia da vontade, pensamento que cedeu com a percepção de que há relações entre particulares pautadas pelas desigualdades ${ }^{164}$.

Se durante o predomínio da concepção liberal recorriase às figuras abuso de direito e da boa-fé contratual para se ultrapassar os problemas gerados pela desigualdade das partes no domínio do Direito Privado ${ }^{165}$, de uns tempos para cá se começou, gradativamente, a recorrer também à aplicação imediata dos direitos fundamentais no domínio das relações privadas, pelo menos neste tipo de relações em que acentuada se mostrou a disparidade de armas. O que foi estudado no item 2.4. deste trabalho e a seguir será objeto de reflexão mais específica.

Os questionamentos acerca da vinculação das entidades privadas pela aplicação dos direitos fundamentais, particularmente pelo direito à igualdade, põem-se a partir do momento em que se constata que não é apenas o estado que pode afetar os direitos e liberdades dos cidadãos mas que, no mundo das relações interprivados, também surgem entidades dotadas de poder e que podem impor sua vontade à contraparte ${ }^{166}$. Segundo a autora portuguesa Júlia Campos, esta realidade se torna ainda mais manifesta no âmbito das relações laborais, porquanto estas, na sua esmagadora maioria, são formadas entre um empregado e "uma entidade dotada de

\footnotetext{
${ }^{164}$ DRAY, Guilherme Machado. Ibidem, p.133. A visão liberal de que só o Estado poderia pôr em causa e ameaçar a liberdade dos indivíduos, já que no âmbito da sociedade civil as relações seriam tendencialmente iguais, cedo se esmoreceu, a partir do momento em que se tornou claro que também as relações entre particulares se poderiam revelar injustamente desiguais, susceptíveis nessa conformidade de pôr em causa o exercício das liberdades individuais. Assim, a existência de relações desequilibradas e desiguais entre sujeitos privados veio, a este propósito, pôr em dúvida o modelo liberal segundo o qual apenas o Estado poderia ameaçar a liberdade individual de cada um. Ou, dito de outra forma, a constatação de que existem, também no domínio privado, relações contratuais (designadamente laborais) nas quais uma das partes se encontra em clara posição de superioridade perante a contraparte, bem como a existência de grupos sociais e economicamente poderosos veio reforçar a idéia de que também a nível privado a existência e o desenvolvimento de relações tendencialmente desiguais pode ser uma realidade que importa evitar, porque atentatória a liberdade individual no que tange à parte contratual tendencialmente mais fraca (Ibidem, p. 134).

${ }^{165}$ Ibidem. Na doutrina brasileira,bastante interessante é a dissertação de mestrado do magitrado paranaense Leornardo Vieira Wandelli que defende que a dispensa imotivada, conquanto não seja vedada no ordenamento brasileiro, pode se mostrar ilícita por consubstanciar um abuso de direito ou falta de boa-fé contratual. (WANDELLI, Leonardo Vieira. Despedida Abusiva. O direito (do trabalho) em busca de uma nova racionalidade. São Paulo: LTr, 2004).
} 
poder suficiente - a entidade empregadora - para impor à contraparte as condições segundo as quais se cai reger a relação entre as partes" ${ }^{167}$.

Em sentido convergente são os ensinamentos de Luis Gabriel Martínez Rocamora, para quem a igualdade é um desses "superprincípios constitucionais" que fundamentam o ordenamento jurídico em sua globalidade e que adquire uma especial relevância no Direito do Trabalho. Em seu entendimento, a igualdade é um ingrediente essencial que informa praticamente a totalidade dos temas fundamentais da disciplina laboral ${ }^{168}$.

Também Manuel García Fernández alerta para a importância da aplicação do princípio da igualdade na formação do Direito do Trabalho asseverando que o princípio da igualdade aplicado às relações laborais representa a "norma fundamental que obriga a tratar da mesma maneira (em quantidade e qualidade) trabalhos semelhantes entre si e, em conseqüência, os trabalhadores que desempenham estes trabalhos"169. Ou, em outras palavras, norma que obriga "que os trabalhadores gozem dos mesmos direitos quando desempenham trabalhos semelhantes ou similares" $"$.

Em sua opinião a transcendência do princípio da igualdade na formação do Direito do Trabalho reflete a importância desta idéia na configuração da comunidade política de nossos dias, do Estado Moderno. A aspiração a que nós humanos sejamos iguais e igualmente tratados pode ser rastreada em toda a história de nossa linhagem e posta em prática mais efetivamente nas comunidades primitivas. Segundo ele, a evolução da sociedade em direção a uma organização cada

${ }^{166}$ CAMPOS, Julia. Igualdade e não discriminação no direito do trabalho. In: IV Congresso Nacional de direito do trabalho. Coimbra: Livraria Almedina, 2002, p. 278.

167 Ibidem, p. 278.

168 "la igualdad es uno de esos $<<$ superprincipios constitucionales que fundamentan el ordenamiento jurídico en su globalidad y que adquire una especial relevancia en el Derecho del Trabajo. En efecto, la igualdad es un $<<$ ingrediente esencial $>>$ de nuestro modelo de relaciones laborales, que informa la pratica totalidad de los temas fundamentales de la disciplina laboral. Tanto es aí, que ha acabado por convertirse en un $<<$ principio general de elaboración y aplicación del Derecho del Trabajo $>>$ " (ROCAMORA, Luis Gabriel Martínez. Decisiones Empresariales y Principio de Igualdade. Barcelona: Cedecs Editorial S.L., 1998, p. 27).

169 "norma fundamental que obliga a tratar de la misma manera (en cantidad y calidad) a trabajos semejantes entre sí y, en consecuencia, a los trabajadores que desempeñan estos trabajos” (Ibidem, p.19)

170 “que los trabajadores gocen de los mismos derechos cuando desempeñan cometidos idénticos o similares". (Ibidem, p.20). 
vez mais complexa trouxe consigo o progressivo desaparecimento da idéia e sua prática e a instalação da contrária, a hierarquia entre funções e pessoas ${ }^{171}$.

O fato é que sendo o Direito do Trabalho um ramo eminentemente protecionista da ciência jurídica, que busca justamente equilibrar as forças das partes da relação jurídica, instituindo proteção à parte mais fraca, a tutela da liberdade contratual deixa de se justificar de forma absoluta. Como salienta Júlia Campos a liberdade contratual não pode funcionar como instrumento lesivo de direitos fundamentais, nomeadamente do direito à igualdade, o que torna necessário encontrar uma forma de articulação entre os dois institutos. O importante, em sua opinião, é saber em que medida a liberdade contratual pode ser limitada em função da aplicação das regras da igualdade, de forma a evitar os potenciais abusos a que será tentada a entidade dotada de maior poder, especialmente no momento da celebração do contrato $^{172}$.

A liberdade de contratar é inerente ao poder diretivo, também chamado empregatício, do empregador. Afinal, o empregador tem a gestão empresarial e, no domínio do contrato de trabalho, é-lhe conferido o poder de direção. Poder, contudo, que não é absoluto. Já no final dos anos setenta e início dos nas oitenta o Professor Octávio Bueno Magano identificava uma propensão a não se conceber o poder diretivo como direito potestativo e sim como direito-função, com o que ressaltou não se tratar de um direito a ser exercido no interesse exclusivo do empregador, mas tendo em vista também o interesse da comunidade dos empregados ${ }^{173}$. Corroborando este ponto de vista, Vera Lúcia Carlos destaca que a empresa não pode se direcionar única e exclusivamente à finalidade lucrativa, devendo pautar-se também na sua finalidade social. O que implica em assegurar a todos uma existência digna com igualdade de condições, o que só pode ser atingido com a abstenção da prática de qualquer conduta discriminatória, quer no momento da contratação, quer durante a execução do contrato de trabalho ou mesmo por ocasião de seu término ${ }^{174}$.

\footnotetext{
${ }^{171}$ Ibidem, p.20.

${ }^{172}$ CAMPOS, Julia. Op. cit., p.278 .

${ }^{173}$ MAGANO, Octávio Bueno. Do poder diretivo na empresa. São Paulo: Saraiva, 1982, p. 30.

${ }^{174}$ CARLOS, Vera Lúcia. Op. cit., p. 23.
} 
Por isso, é inegável que existem limites ao poder diretivo. Para Pedro Romano Martinez o trabalhador não deve obediência à entidade patronal sempre que as ordens ou instruções se mostrem contrárias aos seus direitos e garantias ${ }^{175}$. E sendo a percepção de um tratamento igualitário um direito constitucionalmente consagrado, é evidente que dentro do poder diretivo encontra-se a proibição de discriminar ${ }^{176}$.

Há que se analisar também se o direito a um tratamento igualitário é aplicável aos contratos de trabalho simplesmente por se tratar de um direito fundamental decorrente do princípio da igualdade, o que significa que ele se impõe a todos os liames empregatícios mesmo que não haja lei o estabelecendo, ou se para tanto é imprescindível a existência de uma norma imperativa estatal. Esta discussão é particularmente importante para se chegar a uma conclusão quanto à vedação de qualquer forma de discriminação ou apenas daquelas expressamente estabelecidas em lei. Para tanto, convém retornar à analise da aplicabilidade dos direitos às relações particulares, e, por conseguinte, do princípio da igualdade.

Quanto a esta questão, Júlia Campos destaca existirem três correntes doutrinárias distintas. A primeira delas integrada por aqueles que defendem a inaplicabilidade total dos direitos fundamentais nas relações interprivadas, salvo quando, os instrumentos próprios do direito privado os transponham para institutos deste ramo, o que se traduz na eficácia mediata dos direitos fundamentais. Para os que a ela se filiam, institutos como a ordem pública e a boa-fé seriam suficientes para salvaguardar o respeito pelos direitos fundamentais quando estes fossem alvo de violação na relação entre particulares. A sua preocupação maior é salvaguardar o pleno funcionamento da autonomia privada e da liberdade contratual ${ }^{177}$.

O segundo grupo destacado pela autora lusitana defende a aplicabilidade dos direitos fundamentais, e em especial do princípio da

\footnotetext{
${ }^{175}$ MARTINEZ, Pedro Romano Martinez. Direito do Trabalho. Combra: Almedina, 2002, p. 574.

176 Neste sentido é o magistério de Octávio Bueno Magano: "A proibição de discriminar implica séria restrição ao poder diretivo. Se estendida à cessação do contrato de trabalho, pode implicar até a supressão do direito de despedir. No entanto, mesmo quando confinada ao âmbito salarial ao das admissões em emprego, representa claríssimo contraste ao arbítrio do empregador”. MAGANO, Octávio Bueno. Do poder...op. cit., p. 30.

${ }^{177}$ CAMPOS, Julia. Op. cit., p. 279.
} 
igualdade, nas relações interprivadas mas de uma forma atenuada. Em sua opinião a aplicação dos direitos fundamentais nas relações entre privados teria que ser adaptada às regras próprias do direito civil, como por exemplo utilizando-se de institutos como a culpa in contraendo ou a alteração anormal das circunstâncias ${ }^{178}$.

Finalmente há um grupo de autores que defendem a aplicabilidade aos particulares dos direitos fundamentais com a mesma intensidade das relações entre Estado e particulares ${ }^{179}$.

Feitas estas observações, Júlia Campos observa que independentemente da posição assumida, os integrantes das diversas correntes antes narradas são unânimes em acentuar que nas relações privadas em que uma das partes tem notoriamente uma posição de supremacia sobre a outra - hipótese que se verifica na maior parte das relações laborais - , os direitos fundamentais, em especial o direito à igualdade e não discriminação será diretamente aplicável, seja através da sua transposição para instrumentos específicos do direito civil, como seja a culpa in contraendo, a alteração anormal das circunstâncias ou o respeito pela ordem pública, que tem a função de delimitar o campo de atuação da entidade com posição superior ${ }^{180}$. Em outras palavras, o entendimento esposado neste trabalho é o de que a vedação a qualquer conduta que viole o direito à um tratamento igualitário não pressupõe a existência de uma norma infraconstitucional a proibindo, decorrendo antes diretamente do direito fundamental consubstanciado no princípio da dignidade da pessoa humana, e do princípio da igualdade a ele umbilicalmente ligado.

Tem-se, com isso, a conclusão de que a vedação a condutas discriminatórias nas relações entre empregado e empregador decorre da própria eficácia horizontal do princípio da igualdade, razão pela qual mesmo nos ordenamentos jurídicos onde não tenha sido desenvolvida uma legislação de combate a estas práticas odiosas, - o que não é o caso do Brasil - , há como combatê-las. De igual maneira novas formas de discriminação, contra as quais ainda não se dispõe de texto normativo, podem ser combativas através da aplicação direta do postulado da

\footnotetext{
${ }^{178}$ Ibidem, pp. 279/280.

${ }^{179}$ Ibidem, p. 280.

${ }^{180}$ Ibidem, p. 282.
} 
igualdade. Reforça-se, também a conclusão de que em um confronto entre o direito à igualdade dos trabalhadores e o direito do empregador à liberdade, em matéria de relação de emprego, sempre pautada por uma presumida desigualdade de forças entre as partes, aquele deve se sobrepor a este, por estar mais próximo do conceito de dignidade da pessoa humana.

\subsection{PRINCÍPIO DA IGUALDADE E O LEGISLADOR.}

Em uma análise mais apressada poder-se-ia equivocadamente concluir que o princípio da igualdade nada mais é do que o postulado que interdita que se confira tratamento não uniforme às pessoas. Esta assertiva, contudo, não resiste a uma análise mais apurada, porquanto a função precípua da lei consiste justamente em dispensar tratamentos desiguais. Como salienta Celso Antônio Bandeira de Mello, "as normas legais nada mais fazem que discriminar situações, à moda que as pessoas compreendidas em umas ou em outras vêm a ser colhidas por regimes diferentes" ${ }^{\prime 181}$. Em outras palavras, a distinção dos cidadãos em categorias diferentes por imperativo legal assegura-lhes uma gama de direitos e obrigações não extensíveis aos que se encontrem em condição jurídica díspar.

Ora, se a própria atividade legislativa consiste em instituir distinções, a única forma possível de se harmonizar os princípios da igualdade e da legalidade é reconhecer a existência de situações em que o tratamento diferenciado conferido pela lei não viola o primeiro postulado referido. É preciso então descobrir uma forma de se evidenciar que diferenciações não podem ser feitas sem quebra da isonomia.

Para Celso Antônio Bandeira de Mello, tem-se, primeiramente, que investigar aquilo que é adotado como critério discriminatório, verificando se há critérios objetivos e moralmente fundamentados para, à vista do traço

\footnotetext{
${ }^{181}$ MELLO, Celso Antonio Bandeira de. Op. cit. p. 12.
} 
desigualado acolhido, atribuir o específico tratamento jurídico construído em razão da suposta desigualdade. Feito isso, cumpre analisar se a correlação ou fundamento racional abstratamente existente é, in concreto, afinado com os valores prestigiados no sistema normativo constitucional. Resumindo, não basta a existência de uma correlação lógica abstrata entre o fator diferencial e a diferenciação conseqüente, é preciso uma correlação lógica concreta aferida em função dos interesses abrigados no direito positivo constitucional ${ }^{182}$.

Em outra passagem o renomado publicista destaca que em razão do princípio da igualdade visar tanto propiciar garantia individual contra perseguições, quanto tolher favoritismos, a lei não pode erigir em critério diferencial um traço tão específico que singularize no presente e definitivamente de modo absoluto, um sujeito a ser colhido pelo regime peculiar; nem o traço diferencial adotado haverá de residir na pessoa, coisa ou situação a ser discriminada. Em suas palavras, "sem agravos à isonomia a lei pode atingir uma categoria de pessoas ou então se voltar para um só indivíduo, se, em tal caso, visar a um sujeito indeterminado e indeterminável no presente" 183 .

Outra assertiva de grande relevância para definir a inadmissibilidade da discriminação prevista em uma lei, é a neutralidade absoluta do fator tempo enquanto condição do pensamento humano, porquanto este nada diferencia os seres ou situações, jamais podendo ser tomado como o fator em que se assenta algum tratamento jurídico desuniforme, sob pena de violência à regra da isonomia. $\mathrm{O}$ que pode vir a ser erigido como fator de discriminação são os fatos ou situações que nele transcorrem e por ele se demarcam, desde que, sobre diferirem entre si, haja correlação lógica entre o acontecimento cronologicamente demarcado e a disparidade de tratamento que em função disto se $\operatorname{adota}^{184}$.

Esclarecendo esta assertiva com um exemplo relacionado ao direito do trabalho, pode-se afirmar que a distinção salarial permitida pelo artigo 461, $\S 1^{\circ}$ da CLT em favor dos empregados com dois anos a mais de

\footnotetext{
182 Ibidem, pp. 21/22.

${ }^{183}$ Ibidem, pp. 23/26.

${ }^{184}$ Ibidem, p. 32.
} 
experiência na função não decorre simplesmente do fator tempo, mas da presunção de que o trabalho exercido por aqueles que possuem maior experiência na função apresenta maior valor.

Segundo Bandeira de Mello, "o que autoriza discriminar é a diferença que as coisas possuam em si e a correlação entre o tratamento desequiparador e o dados diferenciais radicados nas coisas"185.

Também assaz relevante é a observação do referido autor de que para a lei conceder tratamento especifico, vantajoso ou desvantajoso, em atenção a traços e circunstâncias peculiarizadoras de uma categoria de indivíduos, imprescindível será a existência de adequação racional entre o elemento diferencial e o regime dispensado aos que se inserem na categoria diferençada ${ }^{186}$.

Por exemplo, uma lei que regulamente, por exemplo, a profissão de contador exigindo dos interessados em exercer a atividade aptidão física plena, negando, outrossim, o exercício da atividade a portadores de deficiência, viola o princípio da isonomia por faltar ao discrímen adequação racional entre o elemento diferencial e o regime dispensado. O mesmo não se pode dizer de uma lei que institua a mesma exigência para os vigilantes, porquanto o vigor físico é inerente a esta profissão.

Há que se ressalvar, contudo que a aludida correlação lógica não é estanque e imutável, variando conforme as concepções de cada época. Veja-se, por exemplo, que se em nossos dias falta correlação lógica a justificar a exclusão das mulheres do acesso a determinadas profissões, como, por exemplo, às atividades de engenharia, o mesmo não se pode dizer da era vitoriana quando inconcebível era as imaginar exercendo este tipo de mister.

Por fim destaca o referido autor não bastar a exigência de pressupostos fáticos diversos para que a lei distinga situações sem ofensa à isonomia. Nem tampouco será suficiente argüir-se fundamento racional. Para ele não é

\footnotetext{
${ }^{185}$ Ibidem, p. 34.

${ }^{186}$ Ibidem, p. 38.
} 
qualquer fundamento lógico que autoriza desequiparar, mas tão-só aquele que se orienta na linha de interesses prestigiados na Constituição Federal ${ }^{187}$.

Luís Roberto Barroso, por sua vez, destaca o importante papel dos princípios da razoabilidade-proporcionalidade para a solução dos impasses ora analisandos, destacando que no direito brasileiro projetaram eles novas luzes sobre o tratamento doutrinário do princípio da isonomia ${ }^{188}$.

Para o constitucionalista carioca, o princípio da razoabilidade desenvolveu-se e difundiu-se no Brasil como uma novidade no campo da hermenêutica jurídica em um período recente ${ }^{189}$. Entre as suas funções, o princípio da razoabilidade permite ao judiciário invalidar atos legislativos ou administrativos quando: (a) não haja adequação entre o fim perseguido e o instrumento empregado; (b) a medida não seja exigível ou necessária, havendo meio alternativo para chegar ao mesmo resultado com menor ônus a um direito individual; (c) não haja proporcionalidade em sentido estrito, ou seja, o que se perde com a medida é de maior relevo do que aquilo que se ganha. Destaca ainda o referido autor que o Supremo Tribunal Federal tem recorrido crescentemente ao princípio da razoabilidade como fundamento para suas decisões, tanto as de invalidação de atos administrativos como as de pronúncia de inconstitucionalidade de leis ${ }^{190}$.

De modo que o referido doutrinador ao final conclui enaltecendo a necessidade de interação entre os princípios da isonomia e da razoabilidade. Sobretudo, tendo em vista que legislar, em última análise, consiste em discriminar situações e pessoas por variados critérios, servindo a razoabilidade como parâmetro pelo qual se vai aferir se o fundamento da diferenciação é aceitável e se o fim por ela visado é legítimo.

\footnotetext{
${ }^{187}$ Ibidem, p. 43.

${ }^{188}$ Ibidem, p.43.

189 BARROSO, Luís Roberto. Razoabilidade e isonomia no direito brasileiro. In: Discriminação: estudos. Márcio Túlio viana, Luiz Otátio Linhares Renault coordenadores. São Paulo: LTr, 2000, p. 28.

${ }^{190}$ BARROSO, Razoabilidade...op cit, p. 31.
} 


\section{DIREITO AO DESENVOLVIMENTO COMO DIREITO FUNDAMENTAL}

Ao se falar em direito ao desenvolvimento, a tendência natural é se pensar em crescimento econômico, progresso nacional ou de um grupo significativamente grande. Pensa-se logo na representação deste no aumento da produção, crescimento do Produto Interno Bruto, incremento das exportações, maior industrialização, etc ${ }^{191}$. Em geral, pouca atenção é dirigida ao direito de cada cidadão de se autodesenvolver para melhorar de vida e buscar a felicidade com os meios que dispõe ao seu alcance. Fato que não passou desapercebido por Paulo Afonso Linhares para quem "a maioria dos planos de desenvolvimento no mundo em desenvolvimento seria muito diferente se sua preocupação fosse com as pessoas (criação de empregos produtivos inclusive) ao invés de ser com a produção per si",192.

Esta situação, contudo, vem se modificando nos últimos anos. Veja-se, por exemplo, que hoje o Produto Nacional Bruto (PNB) não é mais o principal índice de medição do desenvolvimento de uma nação. Percebeu-se, com o passar dos anos que o Produto Nacional Bruto per capita é um critério de mensuração do desenvolvimento, que, embora importante, mostra-se incompleto e impreciso. Segundo Paulo Afonso Linhares os seus principais defeitos são: 1) a sua dependência da taxa de câmbio oficial entre a moeda local e o dólar norte-americano; 2) as distorções que apresenta no tocante à utilização de recursos naturais e deterioração ambiental; e 3) o seu viés economicista, na medida em que reduz o desenvolvimento a uma dimensão estritamente monetária ${ }^{193}$.

\footnotetext{
${ }^{191}$ Segundo José Felipe Ledur (op. cit., p. 136, nota 6),: "Desenvolvimento não tem o mesmo significado de crescimento. $\mathrm{O}$ desenvolvimento implica alteração, para melhor do nível de vida da integralidade da população de um país. O crescimento econômico não traz, necessariamente, o desenvolvimento, já que o aumento em suas taxas pode vir acompanhado do aumento das diferenças socioeconômicas".

${ }^{192}$ LINHARES, Paulo Afonso. Direitos fundamentais e qualidade de vida. São Paulo: Iglu, 2002, p. 45.

${ }^{193}$ Ibidem, p. 49.
} 
$\mathrm{Na}$ tentativa de superar estas limitações foi criado o Índice de Desenvolvimento Humano (IDH), divulgado pela primeira vez em 1990 no Relatório de Desenvolvimento das Nações Unidas, cuja idéia básica consiste na definição do desenvolvimento como processo de ampliação do campo de escolhas aberto à população de um país. Este conceito é operacionalizado através de um indicador numérico que combina de forma engenhosa três índices conhecidos: a) a expectativa de vida ao nascer; b) o grau de escolaridade e alfabetização da população; e c) o nível de renda per capita, mas ajustado à paridade do poder de compra da moeda (para evitar as distorções da conversão pela taxa de câmbio oficial ${ }^{194}$. Vê-se, outrossim, que este índice mais moderno, ainda que divulgue dados globais de uma nação, os estima com base em critérios relacionados ao desenvolvimento de cada cidadão individualmente considerado.

Em tese de doutorado defendida juntamente ao Departamento de Direito Econômico e Financeiro da Faculdade de Direito da Universidade de São Paulo, Carla Abrantkoski Rister destaca a existência de duas concepções de direito ao desenvolvimento: uma objetiva e uma subjetiva. A primeira delas consiste num conjunto de metas utópicas, em um bem comum almejado conjuntamente, identificada originalmente com o simples progresso. Essa acepção objetiva de desenvolvimento é demasiadamente antiga, encontrando seu embrião nos ensinamentos de Aristóteles. O que tem variado ao longo dos tempos são os sentidos e caminhos a serem percorridos para se alcançar o progresso ${ }^{195}$. O desenvolvimento subjetivo, diferentemente, é buscado não de forma harmônica, solidária, mas de forma, egoísta, individualizada ou em pequenos grupos. Consiste, outrossim, na busca que cada indivíduo faz por melhores condições de vida para si e para um reduzido número de entes queridos, sem manifestar preocupação direta com o restante da coletividade ${ }^{196}$.

${ }^{194}$ Eduardo Gianneti da Fonseca, "O que é desenvolvimento econômico", artigo publicado na Folha de São Paulo, de 2.1.1994, pp. 2-6, edição nacional, Seção "Economica Ilustrada” apud LINHARES, Paulo Afonso. Direitos fundamentais e qualidade de vida. São Paulo: Iglu, 2002, p. 49.

${ }^{195}$ RISTER, Carla Abrantkoski. Direito ao desenvolvimeno: antecedentes, significado e conseqüências. 2003. 445f. Tese (doutorado em Direito). Faculdade de Direito. Universidade de São Paulo, São Paulo, pp. $172 / 175$.

${ }^{196}$ Nos dizeres de Carla Rister "O desenvolvimento individual de uma pessoa, por exemplo, ao ocupar determinado posto de trabalho, significa tomar a vaga para si, impedindo que outro possa ocupar tal posto. O desenvolvimento de uma determinada atividade comercial por alguém pode acarretar prejuízo para os concorrentes. O aumento do patrimônio de um empregado em decorrência de uma maior dedicação ao exercício de atividades particulares pode implicar uma retração no patrimônio do empresário e vice-versa. O desenvolvimento em sentido subjetivo é firmado pela competição. Assim, se 
No âmbito da doutrina brasileira, o Procurador do Trabalho Manoel Jorge e Silva Neto trata do direito ao desenvolvimento subjetivo como um dos pressupostos para a dignificação de cada ser humano ${ }^{197}$. Também tratando do tema Bernard Raymond Guimbo destaca que o direito ao desenvolvimento é fundado no reconhecimento da dignidade da pessoa humana, consiste em se interrogar sobre sua universalidade e sobre sua titularidade. Para ele, a partir do momento em que a Declaração Universal dos Direitos do Homem insere em seu preâmbulo e em seu artigo primeiro o princípio do reconhecimento da dignidade inerente a todos os membros da família humana, podemos deduzir que todos os homens e todas as mulheres, onde quer que se encontrem, possuem direito ao desenvolvimento. Para ela, não se pode definir os direitos do homem, e, por conseguinte, o direito ao desenvolvimento, sem se referir ao postulado fundamental que é a dignidade. Para ele é preciso ainda mostrar que o direito ao desenvolvimento é inerente ao homem e que ele veicula uma idéia de justiça ${ }^{198}$.

No tocante ao primeiro ponto o autor destaca que o ser humano é um ser simultaneamente autônomo e dependente de outros, e, por isso, capaz de ditar o seu destino, isto é descobrir aquilo que ele deve realizar por si no mundo com

o desenvolvimento objetivo é motivado pela ambição ou busca do sucesso para todos, indistintamente, o subjetivo é estimulado pela inveja ou pela inevitável comparação com os resultados do co-partícipe do jogo" (Ibidem, p. 180).

${ }_{197}$ É o que se depreende do seguinte extrato: "Ser humano é a única e exclusiva exigência para a incorporação dos direitos universais à vida, à liberdade, à intimidade, ao trabalho, ao desenvolvimento. Representam um conjunto de garantias que passaram a se incorporar gradativamente aos sistemas jurídicos, cuja universalidade, longe de se constituir em barreira à dignificação do individuo, evidencia o cuidado da sociedade pós-moderna em buscar um modo mais eficaz de concretizá-los"( SILVA NETO, Manoel Jorge e. Proteção constitucional dos interesses trabalhistas: difusos, coletivos e individuais homogeneos. São Paulo: LTr, 2001, p. 47.).

${ }^{198}$ Dire que le droit au développement est fondé sur la reconnaissance de la dignité humaine, c'est s'ínterroger sur son universalité et partant sur son titulaire. À partir du moment où la Déclaration universelle des droits de l'homme pose en son préambule et en son article 1er le principle de $<<$ la reconaissance de la dignité inhérent à tous les membres de la famille humaine >>, on peut en déduire que tout homme et tous les femmes, où qu'ils se trouvent, en Afrique ou Ailleurs, ont droit au développment, surtout lorsqu'il est établi que le fondement des droits de l'homme c'est l'égale. Ainsi, on ne peut définir les droit de l'homme, et partant le droit au développement sans se référer à ce postulat fondamental qu'est la dignité. Le droit se trouve quasiment impuissant à justifier un tel postulat. Pour cette raison, une autre démarche rationnelle est nécessaire. Elle consiste à montrer que le développement est consubtantiel à l'homme (a), et que le droi au développment véhicule l'idée de justice (B). (GUIMBO, Bernard Raymond. Droit au développment et dignité humaine. In Les droits fondamentaux: universalité et diversité; Droit au développement; Démocratie et État de Droit; Commerces illicites. Bruxelles: Emile Bruylant: 1997, p.77). 
outros para ser autenticamente humano. Ele é então um ser em constante desenvolvimento, crescimento e progresso, sempre em marcha para sua plena realização ${ }^{199}$. Para Guimbo, o direito ao desenvolvimento decorre da própria natureza social que o homem deve assumir e fazer valorizar; de seu potencial criativo, pelo qual ele deve vencer os contingentes materiais que o circundam; de sua liberdade que lhe apresenta como um ser autônomo e que faz com que ele seja responsável por seus atos, sujeito e fim de suas atividades, sendo, por isso, que ele possui uma eminente dignidade, donde se deduz suas prerrogativas invioláveis quanto ao exercício de sua autonomia; e, por fim, de sua sede de conhecimento que o une de forma transcendental ao seu ser ${ }^{200}$.

Ainda sobre o mesmo ponto, Guimbo aduz que o desenvolvimento é natural ao homem, relacionando-se com aquilo que o homem vive dentro de sua singularidade, seu dinamismo, sua busca de plenitude em direção à transcendência. O desenvolvimento resume bem a tensão do homem em direção à plenitude do ser. É um desenvolvimento que concerne a toda pessoa humana e toda a pessoa humana ${ }^{201}$.

Guimbo demonstra ainda em seus estudos que o direito ao desenvolvimento é objeto próprio da justiça. Afinal, é um direito que busca um efeito que o bem comum consiste dentro da criação de condições políticas e sociais que permitem a cada um exercer sua autonomia, da maneira mais satisfatória, sem que um lese a dignidade do outro. Desta feita, os seres humanos podem perceber, em virtude de um conhecimento de si e do outro, as exigências fundamentais segundo as quais eles

${ }^{199}$ L'étre humain, par une réflexion par l'interieur de son existence sur le fondement et le sens de celleci, se découvre comme un être à la fois autonome et dépendant par rapport à ce qui n'est pas lui. Partant, la personne humaine est capable de saisir sa destinée, c'est-à-dire de découvrir ce qu'elle doit réaliser pour soi, dans le monde avec les autres, afin d'être authentiquement humaine. Elle est donc un être en developpment, en croissance et en progrès, toujours en marche vers sa pleine réalisation (ibidem, p. 77).

${ }^{200}$ L'étre humain, par une réflexion pour l'interieur de son existence sur le fondement et le sens de celleci, se découvre comme un être à la fois autonome et dépendant par rapport à ce qui n'est pas lui. Pourtant, la personne humaine est capable de saisir sa destinée, c'est-à-dire de découvrir ce qu'elle doit réaliser pour soi, dans le monde avec les autres, afin d'être authentiquement humaine. Elle est donc un être en developpement, en croissance et en progrès, toujours en marche vers sa pleine réalisation (Ibidem, p. 77)

${ }^{201}$ Tel qu'il apparaît, le développement est naturel à l'homme; il rend compte de ce que l'homme vit dans sa singularité, son dynamisme, sa recherche de plenitude vers la transcendance. Le développement résume bien la tension de l'homme vers la plénitude d'être. C'est un développement qui concerne tout personne humaine e toute la personne humaine(Ibidem, pp. 77/78). 
devem orientar seus comportamentos, para desenvolver a humanidade em direção à felicidade. A coerência de tal sistema supõe que cada membro da comunidade seja considerado fundamentalmente igual aos outros. Esta igualdade somente pode se sustentar sobre o que for especificamente humano em cada um deles, sua autonomia, que funda uma igual dignidade ao lado de toda diferença, possivelmente, secundária ${ }^{202}$. Desta feita, o direito ao desenvolvimento, por veicular a idéia de justiça, mostra-se susceptível de restabelecer a igualdade entre os homens ${ }^{203}$.

Para o mesmo autor o direito ao desenvolvimento, verdadeiro enraizamento dentro da própria pessoa humana, formula bem o seu movimento genérico, em constante procura por seu ser individual e social. Ele deve ser organizado e exprimir todos os níveis de humanidade para assegurar a todos os seres humanos este crescimento em direção ao quais todos tendem naturalmente ${ }^{204}$.

O direito ao desenvolvimento liga-se aos direitos subjetivos e faz parte da terceira geração de direitos, os direitos de solidariedade. Ele é destinado a satisfazer as necessidades tanto materiais quanto não materiais da pessoa humana. Ele supõe, por conseguinte, uma divisão de chances e de materiais ${ }^{205}$.

A finalidade do direito ao desenvolvimento está intrinsecamente ligada ao respeito à dignidade da pessoa humana, porquanto esta é

${ }^{202}$ Le mot droit est lié à la justice, qui régit les rapports en société et oblige à rendre à chacune ce qui lui est dû, c'est-à-dire ce a quoi il a droit. Ainsi entendu, le droit au développement est l'objet propre de la justice. Ce droit postule en effet que $<<$ le bien commun consiste dans la création de conditions politiques e sociales qui permettent à chacun d'exercer son autonomie, de la manière la plus satisfaisante, sans qu'on lèse la diginité de l'autre. Ainsi, les êtres humaines peuvent percevoir, en vertu d'une connaissance de soi et de l'autre, les exigences fondamentales selon lesquelles ils doivent orienter leur comportement, pour dévelloper l'humanité vers le bonheur. La cohérence d'un tel système suppose que tout membre de la communauté soi considéré comme fondamentalement égal aux autres. Cette égalité ne peut porter que sur ce qui est spécifiquement humain en chacun d'eux, leur autonomie, qui fonde une égale dignité au delà de toute difference, parfois secondaire (Ibidem, p. 79).

203 Le droit au développement, parce qu'il véhicule l'idée de justice, est suceptible de rétablir l'égalité entre les hommes. (Ibidem, p. 80).

204 En somme, le droit au développement, véritable enracinement dans l'être même de la personne humaine, formule bien le mouvement générique de celle-ci, en constante recherche de sa plénitude d'être individuel et social. Il doit être organisé et exprimé à tous les niveaux de l'humanité pour assurer à tous les êtres humains cette croisance, ce plus-être vers lequel ils tendent naturellement tous. (Ibidem, p. 81).

205 Le droit au développement relève par ces éléments constitutifs des droits de la personne. Il appartient dès lors aux droits subjectifs, et fait partie de la troisième génération des droits, c'est-á-dire les droits de solidarité. Il est destiné à satisfaire les besoins tant matériels que non matériels de la personne humaine. Il suppose par conséquent une répartition des chances et des ressources (Ibidem, p. 81). 
assegurada pela observância daquele. Com efeito, o ator central do desenvolvimento, o ser humano, constitui, em última análise, a finalidade suprema do desenvolvimento. Sob este ponto de vista, o direito ao desenvolvimento aparece, e de forma incontestável, como um direito do homem, um direito cujo objetivo é a melhoria constante do bem-estar dos indivíduos aos quais ele deve assegurar integral e livre desabrochar ${ }^{206}$.

Guilherme Machado destacou que, com base em julgados da Corte Constitucional Federal Alemã, que o sistema global de valores presentes na Carta Magna daquele país se assentava na existência de três axiomas a dignidade da pessoa humana, o livre desenvolvimento do ser humano e a igualdade, enfatizando a relação, inclusive, a estreita relação entre os dois primeiros ${ }^{207}$.

O direito ao desenvolvimento, há que se dizer, restou consagrado em uma gama de documentos internacionais ao longo da história. Veja-se que já na Declaração de Independência dos Estados Unidos, fala-se na busca do cidadão pela felicidade como um de seus direitos inalienáveis ${ }^{208}$. O que não deixa de se a consagração do direito que todos possuem de se autodesenvolver em busca de melhores condições de vida. Direito esse consagrado de uma forma ainda mais direta na Convenção relativa aos Direitos da Criança, que em seu art. 17 consagra o direito

\footnotetext{
${ }^{206}$ Le droit au développement pose le problème de sa finalité. Celle-ci concerne le respect de la dignité de l'homme, puisqu'il est le bénéficiaire du droit au développement. En effet, <<acteur central du développement, l'être humain constitute, en dernière analyse, la finalité suprême du développement $>>$. De ce point de vue le droit au développement $<<$ apparaît, et de manière incontestable, comme un droit de l'homme, un droit dont le but est l'amélioration constante du bien-être des individus auxquels il doit assurer l'entier et libre épanouissement $>$. Mais, formuler un objectif et une chose, l'atteindre en est une autre.(Ibidem, p. 84)

${ }^{207}$ Esta "jurisprudência de valores", reiterada em decisões jurisprudenciais mais recentes, entendia que o sistema global de valores presentes na Constituição assentava na existência de três 'axiomas' que deveriam ser entendidas como os mais altos valores "fundamentais" presentes na Constituição: a dignidade do ser humano, o livre desenvolvimento do ser humano e a igualdade perante a lei dos seres humanos. De acordo com esta concepção, a relação entre estes valores operar-se-ia da seguinte forma: a ligação entre a dignidade e o livre desenvolvimento da pessoa humana seriam evidentes, dado que a dignidade da pessoa humana consiste no facto de um indivíduo deve ser considerado não como um "objecto" mas sim como um "sujeito" e de, enquanto sujeito, ter como principal qualidade a faculdade de se autodeterminar e de se desenvolver livremente. Mas dado que esse "sujeito" não vive isolado, mas sim inserido numa colectividade, o reconhecimento da sua liberdade só se tornaria possível se the reconhecêssemos uma igualdade de tratamento com todos os outros sujeitos da colectividade (DRAY, Guilherme Machado. Op. cit., p.129).

${ }^{208}$ We hold these truths to be self-evident, that all men are created equal, that they are endowed by their Creator with certain unalienable Rights, that among these are Life, Liberty and the pursuit of Happiness. Disponível em: <http://www.archives.gov/national-archivesexperience/charters/declaration_transcript.html>. Acesso em 12 de janeiro de 2008.
} 
das crianças ao acesso a uma formação apropriada e no artigo seguinte fala expressamente na responsabilidade dos pais pelo desenvolvimento de seus filhos, nos seguintes termos:

\begin{abstract}
Artigo 17
Os Estados Partes reconhecem a importância da função exercida pelos órgãos de comunicação social e asseguram o acesso da criança à informação e a documentos provenientes de fontes nacionais e internacionais diversas, nomeadamente aqueles que visem promover o seu bem-estar social, espiritual e moral, assim como a sua saúde física e mental. (...)

Artigo 18

1. Os Estados Partes diligenciam de forma a assegurar o reconhecimento do princípio segundo o qual ambos os pais têm uma responsabilidade comum na educação e no desenvolvimento da criança. A responsabilidade de educar a criança e de assegurar o seu desenvolvimento cabe primacialmente aos pais e, sendo caso disso, aos representantes legais. $\mathrm{O}$ interesse superior da criança deve constituir a sua preocupação fundamental ${ }^{209}$.
\end{abstract}

A Carta africana dos direitos do homem e dos povos, por sua vez consagra o direito dos povos ao desenvolvimento e o dever do Estado de assegurá-lo em termos que se aplicam com perfeição ao que aqui tratamos como desenvolvimento subjetivo:

Art. 22. 1. Todos os povos possuem direito ao seu desenvolvimento econômico, social e cultural, dentro do respeito estrito de sua liberdade e de sua identidade, e ao deleite igual do patrimônio comum da humanidade.

2. Os estados possuem o dever, separadamente ou em cooperação de assegurar o exercício do direito ao desenvolvimento ${ }^{210}$.

Em meados dos anos oitenta, o desenvolvimento

humano restou de uma vez por todas elevado à categoria de direito humano fundamental inalienável pela Declaração sobre o Direito ao Desenvolvimento,

\footnotetext{
${ }^{209}$ Disponível em: <http://www.unicef.pt/docs/pdf_publicacoes/convencao_direitos_crianca2004.pdf $>$. Acesso em 12 de fevereiro de 2007.

${ }^{210}$ Art. 22. 1. Tous les peuples ont droit à leur développemente économique, social et culturel, dans le respect strict de leur liberté et leur identité, et à la jouissance égale du patrimoine commum de l'humanité. 2. Les états ont le devoir, séparément ou en coopération, d'assurer l'exercice du droit au développement. Disponível em: <http://www1.umn.edu/humanrts/instree/french/fz1afchar.html>.
} 
aprovada na Resolução n. 41/128 da Assembléia das Nações Unidas, de 4 de dezembro de 1986 , e tem a pessoa humana como sujeito central nesse processo ${ }^{211}$

Este documento internacional apresenta, em seu artigo $8^{\circ}$ um elenco daqueles que são considerados, no Direito ao desenvolvimento, "recursos básicos", atribuindo a cada Estado a responsabilidade pela tomada de medidas que assegurem à todos igualdade de oportunidade no acesso a eles - são a educação, serviços de saúde, alimentação, habitação, emprego e distribuição eqüitativa da renda, com vistas à erradicação de todas as injustiças sociais ${ }^{212}$.

A Organização Internacional do Trabalho (OIT) também consagrou o direito ao desenvolvimento ao incluir, já nos considerandos da Convenção n. 111, o seguinte:

Considerando que a Declaração de Filadélfia afirma que todos os seres humanos, seja qual for a raça, credo ou sexo, têm direito ao progresso material e desenvolvimento espiritual em liberdade e dignidade, em segurança econômica e com oportunidades iguais;

Há, é bem verdade, outras manifestações de desenvolvimento subjetivo como a busca por autoconhecimento e por, amadurecimento. Estas, porém, não serão objeto do presente estudo porquanto se situem mais no âmbito da moral do que do direito ${ }^{213}$. Aliás, o próprio direito à livreconcorrência não será aqui estudado vez que, embora se constitua em um corolário natural do autodesenvolvimento, ele não se manifesta nas relações de trabalho de subordinado, incluindo-se no âmbito do Direito Econômico e não no do Direito do Trabalho.

${ }^{211}$ PINTO, Airton Pereira. Direito do trabalho, direitos humanos sociais e a Constituição Federal. São Paulo: 2006, p. 152.

${ }^{212}$ Disponível em: <http://www.dhnet.org.br/direitos/sip/onu/spovos/lex170a.htm>.

${ }^{213}$ Consoante leciona Washington de Barros Monteiro, embora o direito e a moral regulem atos de seres livres, os homens, tendo um e outro por fim o bem-estar do indivíduo e da sociedade, esta possui um campo mais amplo que aquele, abrangendo os deveres do homem para com Deus, para consigo mesmo e para com seus semelhantes. Outras distinções entre Direito e Moral apontadas pelo Professor Emérito da Faculdade de Direito da Universidade de São Paulo, consistem no fato de o direito possuir a coação, sendo suas normas providas de sanção; ter por escopo evitar que se lese ou se prejudique a outrem; dirigir-se ao momento externo, físico, isto é, ao ato exterior; e ser bilateral e definido; enquanto a moral é incoercivel; visa à abstenção do mal e a prática do bem; dirige-se ao momento interno, psíquico, 
Desta feita, o presente trabalho focar-se-á no direito à educação, no seu corolário o direito à formação profissional e no direito ao trabalho, por serem as vertentes do direito ao desenvolvimento afrontadas diretamente pela hipótese de discriminação que se pretende analisar.

\subsection{DIREITO AO DESENVOLVIMENTO NO BRASIL}

Fato inquestionável é que o direito ao desenvolvimento restou consagrado já no preâmbulo da Constituição da República Federativa do Brasil, onde se asseverou que o Estado Democrático naquele ato instituído destinava-se a assegurar o exercício dos direitos sociais e individuais, a liberdade, a segurança, o bemestar, o desenvolvimento, a igualdade e a justiça como valores supremos de uma sociedade fraterna, pluralista e sem preconceitos. Vê-se, outrossim, que já em sua expressão solene de propósitos nossa Carta Magna deixa claro que o direito ao desenvolvimento consiste em uma das premissas indispensáveis para se criar uma sociedade sem preconceitos.

Poder-se-ia questionar se o desenvolvimento a que se refere o preâmbulo da Constituição da República é exclusivamente o objetivo ou também o subjetivo. A resposta encontra-se no próprio texto constitucional. Veja-se que o desenvolvimento objetivo tem suas principais expressões no direito à educação, à formação profissional, ao trabalho, à busca por melhores condições de vida e à liberdade de se lançar na iniciativa privada, concorrendo livremente com outros cidadãos em busca de mais valia, todos consagrados direta ou indiretamente ao longo dos inúmeros dispositivos de nossa Carta Magna. O direito à educação e o direito à formação profissional que dele decorre, assim como o direto ao trabalho encontram-se consagrados no caput artigo $6^{\circ}$. O direito à liberdade de concorrência restou elevado a princípio da ordem econômica no artigo 170, IV da Constituição Federal. No mesmo 
dispositivo legal encontra-se consagrado ainda o direito à busca por melhores condições de vida, na medida em que há menção expressa a uma das suas expressões, qual seja, a busca do pleno emprego (art. 170, VIII). Estando consagradas as principais manifestações do direito ao desenvolvimento objetivo no texto constitucional, não há que se duvidar que este restou consagrado constitucionalmente.

Provando ainda que o desenvolvimento de que fala a carta de intenções do direito brasileiro não se limita ao desenvolvimento objetivo, abrangendo também o desenvolvimento subjetivo, há a literalidade do artigo 205 da $\mathrm{CF}$, segundo o qual, a educação, direito de todos e dever do estado será promovida e incentivada com a colaboração da sociedade, visando ao pleno desenvolvimento da pessoa, seu preparo para o exercício da cidadania e sua qualificação para o trabalho. Dispositivo, aliás, que consagra também o direito à formação profissional, relacionando-o diretamente com o direito ao desenvolvimento.

Sendo certo, portanto, que o direito ao desenvolvimento é um direito fundamental e que estes são oponíveis também aos particulares, há que se concluir pela possibilidade de se postular e obter provimento jurisdicional para que ente não estatal, como por exemplo uma empresa ou um empregador pessoa física, seja compelido a respeitar o direito de determinado cidadão ao desenvolvimento subjetivo, em suas mais variadas vertentes, ou a reparar dano causado pela não observância deste. É o que sói ocorrer em situações de discriminação por sobrequalificação.

\subsection{DIREITO À EDUCAÇÃO}

O direito à educação, além de seu valor intrínseco, está ligado, em muitos instrumentos, a outros valores transcendentes, como a paz, a igualdade e a não discriminação, atuando de forma auxiliar ou de apoio, para assegurar 
a efetividade desses outros valores ${ }^{214}$. Com efeito, na medida em que o nível educacional das pessoas melhora espera-se que elas, conhecendo os malefícios provocados pelas guerras, primem pela paz; esforcem-se para tratar as outras igualitariamente e abominar todas as formas de discriminação.

A preocupação com o Direito à Educação é universal, tendo restado ele consagrado nos mais importantes documentos internacionais. No artigo 26 da já referida Declaração dos Direitos Humanos, de 10 de dezembro de 1948, há a proclamação de sua essencialidade como direito de todos os povos ${ }^{215}$. No ano de 1970, Ano Internacional da Educação, a UNESCO, preocupada com o tema do desenvolvimento social no mundo, criou uma comissão para estudar os problemas educacionais da maior parte dos países do mundo e apresentar estratégias de superação, a qual defendeu o princípio da Educação Permanente como fundamento da educação do futuro nos seguintes termos ${ }^{216}$ :

1 - A educação permanente deve ser a pedra angular da política educacional nos próximos anos, tanto nos países desenvolvidos quanto nos países em desenvolvimento para que todo indivíduo tenha oportunidade de aprender durante toda a sua vida;

2 - A educação deve ser prolongada durante toda a vida, não se limitando apenas aos muros da escola. Deve haver uma reestruturação global do ensino. A educação deve adquirir dimensões de um movimento popular.

O direito à educação foi reforçado internacionalmente na Declaração Mundial de Educação para Todos (Jomtien, 1990) que afirma, em seu artigo $1^{\circ}$, que "cada pessoa - criança, jovem e adulto - deve estar em condições de

\footnotetext{
${ }^{214}$ GHIONE, Hugo Barretto. Formação profissional a cargo do empregador: (releitura do direito do trabalho tendo em vista a adaptação do empregado na execução do trabalho). São Paulo: LTr, 2003, pp. $58 / 59$.

${ }^{215} 1$. Toda a pessoa tem direito à educação. A educação deve ser gratuita, pelo menos a correspondente ao ensino elementar fundamental. $\mathrm{O}$ ensino elementar é obrigatório. $\mathrm{O}$ ensino técnico e profissional dever ser generalizado; o acesso aos estudos superiores deve estar aberto a todos em plena igualdade, em função do seu mérito.

2. A educação deve visar à plena expansão da personalidade humana e ao reforço dos direitos do Homem e das liberdades fundamentais e deve favorecer a compreensão, a tolerância e a amizade entre todas as nações e todos os grupos raciais ou religiosos, bem como o desenvolvimento das actividades das Nações Unidas para a manutenção da paz ( In: http://www.unhchr.ch/udhr/lang/por.htm ).

${ }^{216}$ PINTO. Airton Pereira. Direito do trabalho, direitos humanos sociais e a Constituição Federal. São Paulo: LTr, 2006, p. 151.
} 
aproveitar as oportunidades educativas voltadas para atender as suas necessidades básicas de aprendizagem,"217.

Como salientou Aírton Pereira Pinto, a educação, seguindo o compromisso do Brasil com a comunidade internacional, é um direito garantido constitucionalmente a todos os cidadãos, sem distinção de qualquer natureza. Segundo o referido autor, ao tratá-la como primeiro direito social, o legislador constituinte enunciou-a com a fundamentalidade devida, remetendo sua disciplina constitucional para o Título da Ordem Social, que tem como primado o trabalho e como objetivos o bem-estar e a justiça sociais. Por fim destacou, que por objetivar a educação tutelada na Carta Magna desinteressada, objetivando em verdade a realização de fins sociais, deve se realizar com qualidade ${ }^{218}$.

Destacando a fundamentalidade do direito à educação, inclusive como corolário do princípio da dignidade da pessoa humana, há este interessante precedente jurisprudencial:

Quem assume o compromisso com a "formação intelectual"
da filha responde pelos custos com o aprendizado de um
segundo idioma e pelo menos uma atividade artística -
artigos $396,1.687$, do CC; 610 do CPC e $1^{\circ}$, III, da CF -
itens obrigatórios do curriculum de membro de família da
classe média alta. Excluir a filha do aprendizado musical ou
do curso de inglês seria marginalizá-la dentro do próprio
mundo que os pais lhe prometeram quando idealizaram sua
concepção de vida feliz. Negar-lhe a complementação do
conhecimento, com os pais reunindo condições financeiras
para custeio das despesas, seria uma afronta ao sentido da
dignidade da pessoa humana, que a Constituição Federal
adotou como fundamental (TJSP, ADV 02-02/028, n.
100131, Ap. 116.383-4/2, Rel. Ênio Zuliani)

Tamanha foi a importância atribuída pelo legislador constituinte ao direito à educação que na própria definição de salário mínimo (artigo $7^{\circ}$, IV da Carta Magna) estatui dever ele ser capaz de atender às necessidades vitais básicas do trabalhador e de sua família, relacionando entre elas a educação.

\footnotetext{
${ }^{217} \mathrm{http}: / /$ www.unesco.org.br/publicacoes/copy_of_pdf/decjomtien

${ }^{218}$ PINTO, Aírton Pereira. Op. cit., p. 151.

${ }^{219}$ In: BARROSO, Luís Roberto. Constituição da República Federativa do Brasil anotada. $5^{\mathrm{a}}$ edição. São Paulo: Saraiva, 2006, pp. 18/19.
} 
Aliás, a relação entre educação e trabalho apresenta-se como uma via de mão dupla. Por um lado tem-se a determinação de que o salário mínimo deva ser suficiente para atender as necessidades vitais com educação. Por outro, tem-se a educação como um importante instrumento de empregabilidade, estatuindo o artigo 214, IV da Constituição Federal que o plano nacional de educação (Lei n. 9.394/1996), visando à articulação e ao desenvolvimento do ensino em seus diversos níveis, deverá conduzir à formação para o trabalho. Oris de Oliveira, em excelente escorço histórico do ensino profissional no Brasil, destaca com maestria, que "à medida em que se aperfeiçoa o processo produtivo, crescem e são aceitas as exigências de melhor nível de escolaridade" e que houve uma crescente pressão dos fatores econômicos para que houvesse uma mão-de-obra mais qualificada ${ }^{220}$. Em sua opinião a educação e a formação são os principais instrumentos de que se dispõe para preparar as pessoas para o mundo do trabalho dando-lhes empregabilidade que, segundo seu magistério, consistiria na capacidade de obter emprego; de manter-se empregadas, progredir em seu trabalho e adaptar-se às suas alterações; de obter outro emprego, caso deseje mudar de trabalho ou caso seja despedida; e, finalmente, de ingressar e sair da força de trabalho em diversos períodos de seu ciclo vital, o que se mostraria fundamental sobretudo para as mulheres, em razão da maternidade ${ }^{221}$.

Em geral, a capacidade pessoal para encontrar e reter um emprego relaciona-se com a educação geral: quanto menor a educação, maiores são as possibilidades de ficar sem emprego ${ }^{222}$. Afinal, em todo o mundo a falta de qualificação profissional consiste no elemento preponderante na apuração do desemprego, na medida em que a inadequação em relação às exigências do mercado dificulta a inserção dos trabalhadores nele ${ }^{223}$. Como bem salientou Airton Pereira Pinto, desde o ensino profissionalizante até o superior, há uma exigência considerável das empresas, em razão da mudança das estruturas de emprego, à medida que evolui a sociedade e progridem as máquinas, em substituição ao homem ${ }^{224}$. Quem não se adequar a esta realidade tende a ser excluído do mercado de trabalho.

\footnotetext{
${ }^{220}$ OLIVEIRA, Oris de. Trabalho e profissionalização do jovem. São Paulo: LTr, 2004, p. 47.

${ }^{221}$ Ibidem, p. 46.

${ }^{222}$ Ibidem, p. 46.

${ }^{223}$ Ibidem, p. 19.

${ }^{224}$ PINTO, Airton Pereira. Op. cit., p. 154.
} 
Digna de menção foi a correlação entre a inserção no mercado de trabalho e a escolaridade em nosso país, traçada por Oris de Oliveira que distingue cinco níveis de qualificação:

Nula: sem instrução (analfabetos) ou somente os três primeiros aos de instrução formal. São pessoas que não possuem os níveis mínimos compatíveis com as estruturas emergentes da ocupação (emprego).

Baixa: compreende pessoas que tiveram uma escolaridade primária e três anos aos níveis básicos do segundo grau (médio). Apresentam níveis mínimos para começar uma experiência laboral nos setores modernos de emprego. É um segmento heterogêneo onde há, porém, uma base mínima de aprendizagem para começar uma formação polivalente compatível com novas exigências de ocupação.

Média: pessoas com mais de três anos de educação de nível secundário, que têm conhecimentos mínimos para prosseguir estudando e trabalhando em ocupações com maiores requisitos para níveis de abstração e compreensão.

Técnica: pessoas que (sic) uma educação de nível técnico formal adquirida em instituições de formação profissional, como, por exemplo, em instituições governamentais ou privadas técnicas e vocacional.

Superior: pessoas com formação de nível superior adquirida em instituições que sejam universidades ou não (professores, magistério e outros). Tanto na população de 15 a 19 como na de 20 a 24 anos a qualificação varia segundo a vinculação de seus integrantes ao sistema educativo, sendo que há uma concentração maior de jovens com melhor qualificação (superior) nos domicílios mais ricos e de porcentagem com qualificação nula nos pobres ${ }^{225}$.

A importância da educação para a empregabilidade tem aumentado cada vez mais na medida em que, como assevera André Gorz, "o trabalho de produção material, mensurável em unidades de produtos por unidades de tempo, é substituído por trabalho dito imaterial, ao qual os padrões clássicos de medida não mais podem se aplicar" 226 . Nesta nova realidade, o conhecimento passa a ser considerado a força produtiva principal. Sendo a educação uma das principais formas - embora não a única - de se propiciar apropriação de conhecimento, resta inquestionável a importância do direito a ela relacionado. Não fosse isto o bastante, a UNESCO, em seu relatório de monitoramento global de 2005, incluiu entre os benefícios de uma educação de melhor

\footnotetext{
${ }^{225}$ Ibidem, pp. $31 / 32$

${ }^{226}$ GORZ, André. O imaterial, conhecimento, valor e capital. São Paulo: Annablume, 2005, p.15.
} 
qualidade o de contribuir para melhoria dos ganhos do indivíduo ao longo da vida e o robustecer o crescimento da economia nacional ${ }^{227}$.

Sob esta perspectiva, a educação não representa um benefício apenas para o trabalhador, mas também para a Nação. Em outras palavras, a melhoria na educação tem implicações diretas tanto na melhoria do desenvolvimento subjetivo quanto na melhoria do desenvolvimento objetivo. Atentos a este fato, os países em desenvolvimento tem investido maciçamente nesta área, destinando-lhe um percentual de seu PNB cada vez maior ${ }^{228}$.

Ademais, como salienta José Pastore, a educação apresenta um efeito indireto, estimulador do emprego pelo simples fato de que a boa educação atrai os investimentos e estes garantem novos postos de trabalho. E arremata: "Educar adequadamente é garantir o progresso de qualquer Nação. Deixar de educar é perder o passado e eliminar o futuro",229.

Não se pode, contudo, confundir educação com escolarização. Aquele consiste em epíteto mais abrangente, denotando, segundo o artigo $1^{\circ}$ do Plano Nacional de Ensino (Lei n. 9.394/96) "os processos formativos que se desenvolvem na vida familiar, na convivência humana, no trabalho, nas instituições

${ }^{227}$ Better education contributes to higher lifetime earnings and more robust national economic growth, and helps individuals make more informed choices about fertility and other matters important to their welfare. For example, it reduces exposure to HIV/AIDS: research shows that cognitive gains from basic education are the most important factor in protecting teenagers from infection. Such benefits are closely linked to the education levels achieved. UNESCO. "Education for All”: Global Monitoring Report 2005. Paris: UNESCO, 2004. Disponível em: http://www.unesco.org/education/gmr_download/en_summary.pdf $>$, p. 6 .

${ }^{228}$ A taxa de matrícula no ensino superior aumenta rapidamente em todas as regiões e é maior em todos os países para os jovens de ambos os sexos, especialmente na América Latina e no Caribe. Ainda com esse crescimento da escolaridade, que tem sido importante em muitos países do mundo em desenvolvimento, as taxas de matrícula totais [...] mostram considerável variação segundo o grau de desenvolvimento, desde $10,7 \%$ nos países em desenvolvimento até $44,7 \%$ nos países desenvolvidos e nas economias de transição [...]. Na maioria dos países em desenvolvimento a escolarização é obrigatória por um período que oscla entre quatro e oito anos, ao passo que nos países desenvolvidos é obrigatória durante oito anos no mínimo. Somente alguns países em desenvolvimento puderam fechar este espaço (ex., Gabão, Malásia, Namíbia, Peru, Sri lanka e Venezuela). Os países em desenvolvimento aumentaram o gasto público em educação como percentual do PNB desde 1980. Em termos per capita, Ásia oriental e América Latina o incrementaram mais depressa que as nas restantes regiões em desenvolvimento. $\mathrm{Na}$ Ásia oriental, o gasto público em educação por habitante duplicou com o crescimento, ao passo que nos países da América Latina houve incremento de 30\% entre 1982 e 1992. Apesar desses aumentos a distância global entre os países desenvolvidos e em desenvolvimento, no que se refere ao gasto público per capita em educação, cresceu entre 1930 e 1993 (OLIVEIRA,Oris de. op cit, p. 16). 
de ensino e pesquisa, nos movimentos sociais e organizações da sociedade civil e nas manifestações culturais" ${ }^{230}$. Juridicamente falando, a educação, de acordo com o Direito Constitucional Brasileiro, possui três objetivos básicos, nos quais se integram valores antropológico-culturais, políticos e profissionais, quais sejam: a) o pleno desenvolvimento da pessoa; b) preparo da pessoa para o exercício da cidadania; c) qualificação da pessoa para o trabalho ${ }^{231}$. Escolaridade, por sua vez, da forma como utilizada pelo legislador pátrio, denota o estágio em que o aluno se encontra dentro do sistema educacional ${ }^{232}$.

José Pastore, por sua vez, distingue adestramento, que ensina a pessoa a fazer uma coisa bem-feita para o resto da vida, mas só isso, e educação que ensina a pessoa a aprender continuamente ${ }^{233}$.

O legislador constituinte não mostrou preocupação com a escolaridade ou com o "adestramento", mas sim com uma educação que desenvolva a

${ }^{229}$ PASTORE, José. Op. cit., p. 231.

${ }^{230}$ FERREIRA, Auréio Buarque de Holanda. Novo dicionário da língua portuguesa. 3. ed. Curitiba: Positivo: 2004, p. 714.

${ }^{231}$ SILVA, José Afonso da. Comentário...op. cit., p. 784.

${ }^{232}$ Decreto 5.154/2004.

(..)

Art. $3^{\circ}$. Os cursos e programas de formação inicial e continuada de trabalhadores, referidos no inciso I do art. 1o, incluídos a capacitação, o aperfeiçoamento, a especialização e a atualização, em todos os níveis de escolaridade, poderão ser ofertados segundo itinerários formativos, objetivando o desenvolvimento de aptidões para a vida produtiva e social.

(...)

$\S 2^{\circ}$. Os cursos mencionados no caput articular-se-ão, preferencialmente, com os cursos de educação de jovens e adultos, objetivando a qualificação para o trabalho e a elevação do nível de escolaridade do trabalhador, o qual, após a conclusão com aproveitamento dos referidos cursos, fará jus a certificados de formação inicial ou continuada para o trabalho.

Lei 9.394/96.

Art. $9^{\circ}$ A União incumbir-se-á de: (Regulamento)

III - prestar assistência técnica e financeira aos Estados, ao Distrito Federal e aos Municípios para o desenvolvimento de seus sistemas de ensino e o atendimento prioritário à escolaridade obrigatória, exercendo sua função redistributiva e supletiva;

(..)

Art. 27. Os conteúdos curriculares da educação básica observarão, ainda, as seguintes diretrizes:

(...)

II - consideração das condições de escolaridade dos alunos em cada estabelecimento;

(..)

Art. 42. As escolas técnicas e profissionais, além dos seus cursos regulares, oferecerão cursos especiais, abertos à comunidade, condicionada a matrícula à capacidade de aproveitamento e não necessariamente ao nível de escolaridade.

${ }^{233}$ PASTORE, José. Op. cit., p. 231. 
pessoa, prepare-a para o exercício da cidadania e qualifique-a para o trabalho ${ }^{234}$. E este direito não se resume à disponibilidade de turma para acesso à escolaridade, seja no ensino fundamental, médio ou superior, mas a um processo contínuo de aprendizagem.

O que se percebe é a preocupação crescente dos governantes em expandir a escolarização, o que estatisticamente implica dados que impressionam positivamente os organismos internacionais acerca da situação do Brasil, e não com a educação em si, o que não satisfaz aos mandamentos constitucionais. Afinal, como salienta José Afonso da Silva, a Constituição de 1988 eleva a educação, termo que para ele denota o atributo da pessoa humana relacionado ao processo de reconstrução da experiência, ao nível dos direitos fundamentais do homem, quando a concebe como um direito social (art. $6^{\circ}$ ) e direito de todos (art. 205) ${ }^{235}$. Segundo Aírton Pereira Pinto, para além de dar escolas, para se garantir educação, seria pertinente “arregimentar um conjunto de fatores não estanques, que vão desde o local-ponto onde a educação vai acontecer, até o infinito de possibilidades no pensar, na criação autônoma e na garantia de qualidade dos agentes profissionais inseridos nesse processo histórico-educativo",236.

\subsection{DIREITO À FORMAÇÃO PROFISSIONAL}

Como muito bem pontuou Hugo Barreto Ghione, a formação profissional, enquanto direito fundamental, encontra-se reconhecida nas principais declarações e tratados e nos capítulos de garantias sociais das Constituições em uma linha de evolução semelhante a dos demais direitos fundamentais da pessoa. Segundo o referido autor uruguaio, seu aparecimento far-se-á por meio do conteúdo

\footnotetext{
${ }^{234}$ Observe-se que o artigo 205 da Constituição Federal estatui expressamente que "A educação, direito de todos e dever do Estado e da família, será promovida e incentivada com a colaboração da sociedade, visando o pleno desenvolvimento da pessoa, seu preparo para o exercício da cidadania e sua qualificação para o trabalho".

${ }^{235}$ SILVA, José Afonso da. Comentário...op. cit., pp. 783/784.

${ }^{236}$ PINTO, Aírton Pereira. Op. cit. p. 157. No mesmo sentido afirma José Afonso da Silva: "As profundas desigualdades da vida brasileira não propiciam igualdade de condições de acesso à escola e de permanência nela a uma grande massa de estudantes. Para tanto sao necessárias fortes ações afirmativas - que, como dissemos, vão muito além da questão puramente escolar" (Comentário...op. cit., p. 785).
} 
(muitas vezes implícito) do "direito à educação" - hipótese em que se enquadra o direito brasileiro - ou como parte do "direito do trabalho" (ou mesmo como instrumento de sua satisfação) $)^{237}$.

Oscar Ermida Uriarte, ao prefaciar a obra de Hugo Barreto Ghione, destaca que o Direito do Trabalho, atual e futuro, já não pode prescindir da formação como um de seus institutos cada vez mais em destaque. Três são as justificativas que fundamentam essa conclusão. A primeira e essencial consiste no reconhecimento da existência de um direito à formação profissional, direito, segundo ele, além do mais, fundamental, "tendo em vista sua inclusão em vários e importantes pactos e declarações internacionais de direitos humanos e constituições nacionais". Para o renomado jurista uruguaio, esse direito, sempre válido e ativo, ganha maior importância em determinadas situações de flexibilidade funcional e crescerá no futuro, haja vista as perspectivas de redução do tempo de trabalho, paralelas às da necessidade de contínua requalificação, o que, "leva a supor que, cada vez mais, a relação de trabalho será uma relação de trabalho e formação"238.

A segunda justificativa consiste no fato de a formação profissional, assim como antes afirmado acerca da educação, de quem ela é corolário, constituir fator, requisito ou condição de empregabilidade ${ }^{239}$.

Outra justificativa decorre do fato de a formação profissional ser um instrumento econômico que melhora a produtividade e a competitividade da empresa, incentivando a via alta, isto é, a do aumento do valor agregado e da qualidade, em vez de a via baixa, de redução dos custos e deterioração da qualidade. Constitui-se, outrossim, numa vantagem comparativa da empresa que a desenvolve e do país que a converte em eixo de sua política econômica ${ }^{240}$.

\footnotetext{
${ }^{237}$ GHIONE, Hugo Barreto. Op. cit. p. 58.

${ }^{238}$ Ibidem, pp. $15 / 16$.

${ }^{239}$ Segundo Uriarte, ao prefaria o livro de Ghione, "Não é que a capacitação profissional gere novos postos de trabalho, mas tudo indica que melhora a empregabilidade do trabalhador ou do aspirante a sêlo, quer dizer, aumenta as perspectivas dos cidadãos de conseguir um posto de trabalho e fortalece as possibilidades de um trabalhador já empregado manter seu emprego e até crescer nele" (Ibidem p. 16.).

240 Hugo Barreto Ghione, ressalta a importância da formação profissional para empregados, empregadores e para toda a sociedade ao afirmar: "Enfatiza-se que os recursos humanos e a formação para o emprego desempenham papel importante para promover o desenvolvimento econômico eqüitativo, estendendo seus resultados positivos às pessoas, às empresas, à economia, à sociedade em geral, mantendo a empregabilidade e a adaptação em um mercado de trabalho em contínua evolução
} 
Por fim, como destaca Uriarte, a formação profissional oferece um campo fértil para o diálogo social em seus diversos níveis (a própria empresa, o ramo de atividade, o país como um todo, a região, etc.) e em suas diferentes formas (pactos sociais ou acordos-padrão, negociação coletiva, participação, etc.) ${ }^{241}$.

Hugo Barreto Ghione, por sua vez, destaca ainda o caráter hipertextual da formação profissional para justificar a crescente importância de seu estudo. Por caráter hipertextual o autor pretende denotar as múltiplas conexões com diversos aspectos da relação de trabalho e com as mudanças que vêm se processando no mundo do trabalho, fortemente impulsionadas pelo desenvolvimento tecnológico (em equipes e organização do trabalho) e pelas novas condições de competitividade ${ }^{242}$.

O Brasil, contudo, é um país carente em recursos humanos qualificados. Sua força de trabalho apresenta, em média, apenas 4,5 anos de escola, o que além de constituir um entrave para o desenvolvimento econômico consistem restrição grave para a empregabilidade dos trabalhadores ${ }^{243}$.E mais o ensino fornecido não é de qualidade. Segundo conclusão do relatório da UNESCO publicado em novembro de 2004, o Brasil ocupa a $72^{\mathrm{a}}$ posição em matéria de qualidade de ensino entre 127 países $^{244}$.

Há diversos países que tratam da formação profissional já em sua Carta Constitucional. Alguns enquadrando-no no direito à educação, como são os casos da Espanha (art. 27), Portugal (art. 73), El Salvador (art. 53), Colômbia (art. 54), Costa Rica (art. 67) e Nicarágua (art. 85). O Brasil inclui-se neste rol na medida em que, como visto, o artigo 214, IV da Constituição trata da formação para o trabalho de forma conjugada com a educação, asseverando caber ao Estado efetivar o

graças à sua mundialização" (Ibidem, p. 44). O mesmo autor ressalta, "a formação é também funcional, em alguns de seus contornos, na lógica flexibilizadora, na medida em que contribui, de uma parte, para possibilitar a mobilidade "transversal" do trabalhador no emprego e, de outra, a polivalência que permite o desempenho de mais de uma tarefa sem prejuízo da eficácia produtida da empresa em seu todo (Ibidem, p. 26).

${ }^{241}$ Em prefácio do livro do Hugo Barreto Ghione (Ibidem, p. 26).

242 Ibidem, p. 26.

${ }^{243}$ PASTORE, José. As mudanças no mundo do trabalho:leituras de sociologia do trabalho. São Paulo: LTr, 2006, p. 216.

$244 \quad$ Disponível em: <http://ultimosegundo.ig.com.br/materias/educacao/17950011795500/1795080/1795080_1.xml>. Acesso em 15 de janeiro de 2008. 
direito à educação mediante a realização de um Plano Nacional, visando grandes metas para o País; erradicar o analfabetismo; universalizar o atendimento escolar; melhoria da condição de ensino; formação para o trabalho; promoção humanística, científica e tecnológica.

Nestes casos, entende Hugo Barreto Ghione que o direito à formação profissional requer uma ação da parte do Estado que a garanta ${ }^{245}$.

Outros países há em que a formação profissional se enquadra no Direito do Trabalho. Nestes casos a sua eficácia depende da atividade dos atores sociais (art. 123 da Constituição Mexicana) ${ }^{246}$.

Ambas as soluções mostram-se adequadas na medida em que existe uma significativa intersecção entre a educação, a formação profissional e o direito ao trabalho. Com efeito, a formação profissional, no direito brasileiro, é um dos objetivos da educação (Art. 205 e 214, IV da CF). E ambas são garantias de empregabilidade, ou seja, são os meios de se assegurar o direito ao trabalho. Como salienta Oris de Oliveira, "a educação e a formação inicial fundamentam a empregabilidade pessoal; a formação contínua e ensino permanente oferecem os meios para mantê-la durante toda a vida" ${ }^{247}$. O mesmo autor destaca ainda a função dual da educação e da formação profissional como fatores de empregabilidade. A função próativa consistiria em fomentar o conhecimento e as capacidades dos indivíduos e das empresas e a capacidade de toda a economia de maneira que possam ser aproveitadas as potencialidades da mundialização e dos mercados mais abertos; e a mitigadora em engrenar as recentes tendências do mercado de trabalho, servindo de instrumento para impulsionar a empregabilidade, a produtividade e a capacidade de obter o ingresso de pessoas menos habilitadas no mercado de trabalho, promovendo a eqüidade nos resultados do emprego ${ }^{248}$.

Esclarecendo a estreita relação entre formação profissional e o direito do trabalho; bem como a responsabilidade pela implementação daquela, a Organização Internacional do Trabalho editou, em 1962, uma

\footnotetext{
${ }^{245}$ GHIONE, Hugo Barretto. Op. cit., p. 67.

246 Ibidem, p. 67.

${ }^{247}$ OLIVEIRA, Oris de. Trabalho e profissionalização do jovem. São Paulo: 2004, p. 44.
} 
Recomendação sobre a Formação Profissional que condensou o conteúdo de todas as que a antecederam ${ }^{249}$, onde restou consignado o seguinte:

A formação profissional não é um fim em si mesma, sendo um meio para desenvolver aptidões profissionais de uma pessoa, levando em consideração as possibilidades de emprego e de permitir fazer uso de suas capacidades como melhor convenha a seus interesses e aos da comunidade; a formação deveria tender ao desenvolvimento da personalidade, sobretudo quando se trata de adolescentes.

A formação constitui um todo cujos diversos elementos não podem ser dissociados.

A formação é um processo que continua durante toda a vida profissional de um indivíduo, em conformidade com suas necessidades individuais e de membro da comunidade.

A formação deveria ser isenta de toda forma de discriminação por motivo de raça, cor, sexo, opinião política, ascendência nacional ou origem social.

A formação exige a cooperação contínua de todas as pessoas e organismos interessados: autoridades públicas, instituições docentes, organizações de empregadores e trabalhadores ( I - Disposições gerais, n. 2, III - Medidas de Colaboração).

Entre os países do Mercosul, merecem destaque as normas sobre formação profissional da Argentina e do Paraguai. Na Argentina, a Lei n. 24.576 acrescentou um capítulo VIII ao Título II da Lei de Contrato de Trabalho, mediante o qual a formação passa a ser uma obrigação do empregador que “implementará ações de formação profissional e/ou de capacitação com a participação dos trabalhadores...". No Paraguai, por sua vez, o artigo 62 do Código de Trabalho menciona a obrigação do empregador de capacitar em matéria de segurança no trabalho, sem nenhuma referência a uma obrigação genérica com vista, por exemplo, a possibilitar a adaptação do trabalhador.

No Brasil, a Consolidação das Leis do Trabalho trata da questão da formação profissional em poucos dispositivos. Os principais são o artigo 373-A, III, incluído pela Lei 9.799/99, que, ao proibir as discriminações contra a mulher, estatui expressamente que não se pode considerar o sexo como variável determinante para fins de formação profissional, salvo hipóteses de ações afirmativas; e o artigo 476-A, acrescentado pela Medida Provisória n. 2.164-41/01, que possibilitou

\footnotetext{
${ }^{248}$ Ibidem, p. 45.

${ }^{249}$ OLIVEIRA, Oris de. Op. cit. p. 115.
} 
suspensão do contrato de trabalho por um período de 2 a 5 meses, para participação do empregado em curso ou programa de qualificação profissional, mediante previsão em convenção ou acordo coletivo de trabalho. A formação profissional ainda é referida no parágrafo único do artigo 373-A, onde se esclarece que as vedações elencadas em seus incisos não obstam a adoção de medidas temporárias que visem ao estabelecimento das políticas de igualdade entre homens e mulheres, em particular as que se destinam a corrigir as distorções que afetam a formação profissional, o acesso ao emprego e as condições gerais de trabalho da mulher; no artigo 390-B que assevera que as vagas dos cursos de formação de mão-de-obra, ministrados por instituições governamentais, pelos próprios empregadores ou por qualquer órgão de ensino profissionalizante, serão oferecidas aos empregados de ambos os sexos; no artigo 390-C, que estatui que as empresas com mais de 100 (cem) empregados, de ambos os sexos, deverão manter programas especiais de incentivos e aperfeiçoamento de mão-de-obra; e no artigo 390E que faculta à pessoa jurídica associar-se a entidade de formação profissional, sociedades civis, sociedades cooperativas, órgãos e entidades públicas ou entidades sindicais, bem como firmar convênios para o desenvolvimento de ações conjuntas, visando a execução de projetos relativos ao incentivo ao trabalho da mulher.

Cabe destacar ainda o papel dos artigos 428 a 433 da CLT, que tratam do contrato de aprendizagem que, de alguma maneira, consiste em uma espécie de formação profissional. Em verdade, trata-se de uma modalidade especial de contrato que tem como um de seus pressupostos a formação profissional do empregado contratado.

Fora do texto consolidado há que se destacar o artigo 28 do Estatuto do Idoso (Lei 10.741/03), que dispõe expressamente que "o Poder Público criará e estimulará programas de profissionalização especializada para os idosos, aproveitando seus potenciais e habilidades para atividades regulares e remuneradas".

Mesmo com todos os dispositivos suso mencionados, não há como se negar que o ordenamento jurídico brasileiro carece de uma normatização específica e detalhada sobre formação profissional, ficando ao talante dos 
empregadores e de algumas poucas instituições, como, v.g., aquelas que integram o chamado sistema "S", definir como ela se dará.

\subsection{FORMAÇÃO PARA ACESSO AO EMPREGO E MECANISMOS DE} SELEÇÃO LABORAL.

Segundo Héctor-Hugo Barbagelata, citado por Hugo Barretto Ghione, a falta de formação tem sido considerada como risco social por aparecer como contingência que expõe quem a sofre a ter menores possibilidades de acesso a trabalho conveniente, maiores probabilidades de não poder manter-se no emprego nos casos de redução de pessoal e, por isso mesmo, pouca expectativa de promoção, podendo, por conseguinte, ser objeto de cobertura por mecanismos de seguridade social ${ }^{250}$.

Analisando a realidade uruguaia, Hugo Barretto Ghione, destaca a existência de mecanismos de acesso ao emprego realmente atuantes no mercado divididos em três categorias, quais sejam ${ }^{251}$ :

a) mecanismos e redes sociais ou de capital relacional: o qual compreende o acesso ao emprego por meio de relações pessoais (parentesco, amizade, etc. );

b) mecanismos de mercado: os quais reúnem os que fazem a seleção priorizando o desempenho pessoal do candidato e o atendimento às exigências do posto de trabalho (anúncios na imprensa, concurso, provas de aptidão, requerimento direto, etc.);

c) formas mistas: categoria residual que funciona em casos de investimento (créditos, poupança), estudos (fim de carreira) e iniciativa própria (trabalho autônomo).

\footnotetext{
${ }^{250}$ BARBAGELATA, Héctor-Hugo. A propósito de las afinidades, las conexiones y la integración de la formación profesional y la seguridade social, en tiempos de privatizaciones, no vol. Las reformas de la segurida social en Iberoamérica, OISS, Madri, 1998, p. 215. apud Ghione, op cit, p. 51.

${ }^{251}$ Ibidem, p. 53.
} 
Analisando as três categorias destacadas pelo autor uruguaio, há que se destacar desde já que os mecanismos de mercado, enquanto situações de acesso ao emprego, são aqueles nos quais mais facilmente podem se identificar condutas discriminatórias. Os mecanismos de capital relacional em geral não propiciam o surgimento de condutas discriminatórias, porquanto não se pautam por análise meritória, mas por critérios de fidúcia ou mesmo de troca de favores. Em situações excepcionais quando se escolhe com base em motivos relacionais depois de instaurado processo seletivo tem-se uma conduta discriminatória disfarçada. Nas situações mais comuns, em que se escolhe um familiar sem sequer se instaurar processo seletivo, dificilmente caracterizar-se-á uma situação de discriminação. Nas chamadas formas mistas, poder-se-á ter condutas discriminatórias particularmente na forma de estudos (fim de carreira). Nas de investimento e de iniciativa própria, esta hipótese mostra-se pouco provável.

$\mathrm{O}$ autor uruguaio destaca ainda a existência do "ajuste entre a complexidade substantiva das tarefas desempenhadas em seu trabalho e a formação do indivíduo", segundo o qual é possível se classificar os ocupados entre "ajustados" e "desajustados" e, nesses, entre "sobrequalificados" - os que têm formação superior à complexidade das tarefas que realizam - e "subqualificados" - que executam tarefas que correspondem a um nível de complexidade superior ao correspondente em função da educação que receberam ${ }^{252}$.

Analisando o estudo de Boado, Filardo e Prat, Ghione destaca que os ocupados que têm acesso ao emprego por mecanismos relacionais têm maior proporção de desajuste em razão de sua qualificação (46,5\% ajustados contra $53 \%$ desajustados); enquanto os que têm acesso por formas mistas apresentam tendência inversa (18,2\% ajustados contra $11 \%$ desajustados) e, finalmente, quem tem acesso por formas de mercado não tem diferenças significativas, sendo o mecanismo que tem relação mais estreita entre posto ocupacional e formação profissional. Ainda com base no mesmo estudo, Ghione destaca restar apontado que o desajuste identificado nos casos e mecanismo e ocupação relacional apresenta estreita ligação 
com a sobrequalificação do empregado, o que o leva a concluir que o capital relacional representa, nesse ponto, uma clara desvantagem ${ }^{253}$.

\subsection{DIREITO AO TRABALHO}

Segundo o economista J. Carlos de Assis, "o conceito de direito ao trabalho (remunerado) surge no campo político no mesmo momento em que Estados Unidos e França, as primeiras democracias modernas, faziam do direito de propriedade a pedra angular de sua constituição" 254 . Esclarece o autor que trabalho e propriedade eram face e contraface do processo de afirmação do capitalismo emergente, sendo certo, contudo, que este se confundiu com a própria liberdade política republicana e com a cidadania (limitada), enquanto aquele esperaria ainda mais de um século para ser reconhecido, o que só veio a ocorrer no rastro das grandes transformações políticas do século XX, caracterizadas pela ampliação da cidadania política aos não-proprietários ${ }^{255}$. A partir deste momento histórico o direito ao trabalho passou a desempenhar relevante papel deste dentro da vida social participativa ${ }^{256}$.

\section{A Organização Internacional do Trabalho (OIT)} considera o trabalho decente um direito fundamental. Para a referida organização, muito mais do que um meio para gerar renda, assegurando, assim, o sustento e o acesso aos serviços sociais, o trabalho decente mostra-se necessário para a promoção da

\footnotetext{
${ }^{253}$ Ibidem, pp. 54/55.

254 ASSIS, José Carlos de. Trabalho como direito: fundamentos para uma política econômica de promoção do pleno emprego no Brasil. Rio de Janeiro: Contraponto, 2002, p. 27.

${ }^{255}$ Ibidem, p. 27.

${ }^{256}$ Segundo Antônio Rodrigues de Freitas Júnior, "O trabalho permaneceu até há pouco como uma das categorias teóricas centrais para a compreensão da vida socialmente participativa. Ao lado disso, vinha desempenhando função heurística na conformação de doutrinas sociais religiosas, bem como ao seu redor gravitaram utopias, doutrinas políticas, projetos partidários, imaginários culturais, e até mesmo significativa parcela da produção doutrinário no campo do Direito"( FREITAS JÚNIOR, Antônio Rodrigues de. Direito do trabalho na era do desemprego. Instrumentos jurídicos em políticas públicas de fomento à ocupação. São Paulo: LTr, 1999, p. 156).
} 
dignidade e da auto-estima das pessoas, sendo elemento fundamental de reconhecimento e de integração social ${ }^{257}$.

No ordenamento jurídico brasileiro atual ele se encontra consagrado no caput do artigo $6^{\circ}$ da Constituição Federal que inclui, entre os direitos sociais, o trabalho. Trata-se do chamado direito ao trabalho e não do Direito do Trabalho enquanto ramo autônomo do direito, cuja base e princípios são delineados no $\operatorname{artigo} 7^{\circ}$ da mesma Carta Magna. Como salienta José Afonso da Silva, "aqui se tem o trabalho como um direito, a significar que o trabalho é um direito social - o que, em outras palavras, quer dizer: direito ao trabalho, direito de ter um trabalho, possibilidade de trabalhar" ${ }^{, 258}$. Conjugando o referido dispositivo com o artigo $1^{\mathrm{o}}, \mathrm{IV}$, que dá como um dos fundamentos do Estado Democrático de Direito os valores sociais do trabalho, com o disposto no artigo 170, caput, que tem a valorização do trabalho como uma das bases da ordem econômica para o fim de assegurar a todos existência digna; e com o artigo 170, VIII que trata a busca do pleno emprego como um dos princípios da atividade econômica, tem-se que a empregabilidade, que deve ser assegurada não apenas com a criação de novos postos de trabalho, mas também com medidas que lhe propiciem desenvolvimento subjetivo, consiste em direito inerente a todos os brasileiros.

A relação entre o direito ao trabalho e a dignidade da pessoa humana é estreita. Ainda no século XIX a Igreja Católica, através da encíclica Rerum Novarum, atentava para este fato ao ressaltar que o "trabalho dignifica o homem". Com efeito, o trabalho não serve ao homem exclusivamente como propiciador de renda, mas também como instrumento de inserção do cidadão dentro do meio social. O simples fato de possuir um trabalho, independentemente do patamar salarial ou da realização profissional plena, possui o efeito psicológico positivo de fazer com que o cidadão sinta-se útil. Prova disto são os incontáveis exemplos de cidadãos que, enquanto na ativa, apresentavam uma saúde mental satisfatória e, logo

257 ORGANIZAÇÃO INTERNACIONAL DO TRABALHO (OIT). Manual de capacitação e informação sobre gênero, raça, pobreza e emprego: guia para o leitor. Brasília, OIT, 2005, v.1, p. 110. ${ }^{258}$ SILVA, José Afonso da. Comentário...p cit. p. 185. José Felipe Ledur destaca esta distinção salientando que: "sem o direito ao trabalho a existência do Direito do Trabalho não fará nenhum sentido e que a norma do art. $6^{\circ}$, alusiva ao trabalho, e o direitos definidos no art. $7^{\circ}$, ambos da Constituição, se condicionam e se completam mutuamente” (LEDUR, José Felipe. Op. cit., p. 115, grifo do autor). 
após a aposentadoria, se viram acometidos de doenças como esclerose, depressão, $e t c^{259}$.

A relação entre o direito ao trabalho, o direito ao desenvolvimento subjetivo e o postulado da dignidade da pessoa humana, também restou observada por Alberto Avio, para quem o trabalho representa na sociedade hodierna um dos modos típicos e tendenciais de desenvolvimento da personalidade (ou melhor de reconhecimento desta) e também um dos modos de sua exteriorização. Para ele a profissionalidade adquire um valor não patrimonial ligado à dignidade e personalidade do sujeito que se acrescenta ao significado mercantil clássico ${ }^{260}$.

${ }^{259}$ Ressaltando que a importância do trabalho vai muito além de uma mera fonte de renda, observou José Felipe Ledur que: "Se é certo que a pessoa sem trabalho, que vive às custas de familiares, sente-se atingida em seu amor próprio, em sua dignidade, de outro lado o recebimento indefinido de prestações estatais como forma de compensar a falta de trabalho também redunda na depreciação da pessoa ante o seu grupo social. E não é só isso. O desenvolvimento profissional, igualmente, resultaria afetado, porque um trabalhador, máxime em período de intensas mudanças tecnológicas necessita estar no mercado de trabalho para desenvolver sua aptidão profissional. Por isso, paralelamente à ajuda financeira ao trabalhador desempregado, é necessário que existam mecanismos que o mantenham em condições de retornar a atividade profissional, tão logo essa possibilidade se ofereça"(LEDUR, José Felipe. Op. cit., pp. 100/102).

${ }^{260}$ Se il lavoro rappresenta nella società odierna uno dei modi tipice e tendenziali di sviluppo della personalità dell'individuo, la professionalità (o, meglio, il riconoscimento di essa) è - all'interno del rapporto di lavoro ma anche verso l'esterno - uno dei modi di estrinsecazione della personalità. La professionalità, così, acquisisce un valore non patriomoniale del tutto legato alla dignità e personalità del soggeto che si aggiunge al significato mercantile classico". AVIO, Alberto. I diritti inviolabili nel rapporto di lavoro. Serie seconda. Milano: Dott. A. Giuffrè Editore, 2001, p. 102. 


\section{DISCRIMINAÇÃO}

A discriminação não é um fato social recente. As narrativas do antigo testamento já dão conta de preconceitos, tratamentos desiguais e condutas discriminatórias em razão de raça, sexo ou origem no período histórico que precedeu o nascimento de Jesus Cristo. As formas de exteriorização da discriminação no ambiente de trabalho e os motivos pelas quais ela ocorre são os mais variados possíveis. Uma coisa, contudo, é certa: ela precisa ser combatida, por representar um malefício para as vítimas, para o empreendimento, seja ele qual for, e para a sociedade como um todo. Com a sua perpetuação perdem as vítimas, vez que, como destacado no mais recente informe da Organização Internacional do Trabalho sobre o tema, toda discriminação produz efeitos desiguais que as coloca em uma situação de desvantagem que dificulta o seu acesso a oportunidades de emprego e à igualdade de tratamento no trabalho $^{261}$. Perde o empreendimento porquanto o mesmo estudo dá conta de que a discriminação implica queda na motivação dos empregados para trabalhar e obter melhor rendimento, o que resulta em menor produtividade no trabalho e em tensões no ambiente laboral, com as conseqüentes repercussões negativas para a produção geral ${ }^{262}$. Por fim, os estudos da OIT ressaltam que perde ainda a sociedade, haja vista que as formas graves e persistentes de discriminação no trabalho contribuem para acentuar a pobreza e a exclusão social na medida em que preconceitos fundados na origem familiar ou na extração social acabam prevalecem sobre a capacidade das pessoas e sobre suas aspirações reais, condenando-as à inamovibilidade ${ }^{263}$.

\footnotetext{
261 Toda discriminación produce efectos desiguales que ponen a las víctimas en una situación de desventaja, lo cual dificulta su acceso a oportunidades de empleo y, a mayor abundamiento, a la igualdad de trato en el lugar de trabajo. ORGANIZAÇÃO INTERNACIONAL DO TRABALHO (OIT). La igualdad...op. cit., p. 28.

${ }^{262}$ La discriminación se traduce asimismo en menor motivación para trabajar y lograr un buen rendimiento, lo cual redunda en menor productividad laboral y en tensiones en el lugar de trabajo, con las consiguientes repercusiones negativas que ello supone en el rendimiento general y el bienestar en el seno de la empresa. Las prácticas y las políticas de gestión de los recursos humanos que previenen la discriminación en el trabajo y promueven la igualdad de trato y de oportunidades y el abandono de toda distinción arbitraria son provechosas no sólo en el plano personal, sino también en el empresarial. (Ibidem, p. 28).

${ }^{263}$ En cambio, las formas graves y persistentes de discriminación en el trabajo contribuyen a agudizar la
} 
Sendo verdade que todos perdem com as práticas discriminatórias, certo é também que, a contrario sensu, todos têm a ganhar com o seu combate. Como destacou a Organização Internacional do Trabalho em seu mais recente estudo sobre o tema, “A eliminação da discriminação é pressuposto indispensável do trabalho decente para todas as mulheres e homens". Em sua visão, o conceito de trabalho decente se baseia na igualdade de oportunidades para aqueles que trabalham ou buscam emprego e sustento, na economia formal ou informal, seja como empregado, seja como empregador ou como trabalhador autônomo ${ }^{264}$.

O presente trabalho busca, antes de tudo, estudar as formas de combate às condutas discriminatórias de uma maneira geral para, a partir dos subsídios teóricos obtidos, analisar o que aqui se chamou de discriminação por sobrequalificação e os instrumentos disponíveis para combatê-la.

\subsection{CONCEITOS}

Conceituar discriminação não representa uma tarefa tão simples como a primeira vista pode parecer. Em português coloquial, ao contrário do que ocorre em outras línguas, este termo possui sentido equívoco, denotando tanto faculdade de distinguir ou discernir quanto separação, apartação, segregação ${ }^{265}$. Em

pobreza y la exclusión social. Los perjuicios fundados en los orígenes familiares o la extracción social suelen primar sobre la capacidad de las personas y sus aspiraciones reales, lo cual las condena a la inmovilidad social. Las penurias son especialmente dolorosas para quienes son objeto de discriminaciones múltiples, como las personas que no sólo están sumidas en la pobreza, sino que demás pertenecen a una minoría religiosa o racial, además de haber alcanzado una edad avanzada (ibidem, $\mathrm{p}$.

${ }^{264}$ La eliminación de la discriminación es presupuesto indispensable del trabajo decente para todas las mujeres y hombres, el cual «se basa en la igualdad de oportunidades para cuantos trabajan o buscan un empleo y un sustento, ya sea como obreros, como empleadores o como trabajadores por cuenta propia, tanto en la economía formal como en la informal. (Ibidem, p. 133).

${ }^{265}$ FERREIRA, Aurélio Buarque de Holanda. Novo dicionário da lingua portuguesa. $3^{\mathrm{a}}$ edição. Curitiba: Positivo, 2004, p. 686. 
francês, diferentemente, a palavra discrimination é utilizada apenas com este último significado $^{266}$, possuindo, outrossim, sentido unívoco.

No jargão jurídico brasileiro, muito embora a expressão também signifique o ato de separar uma coisa que está unida à outra ${ }^{267}$, ela é muito mais empregada indicando a distinção, exclusão ou preferência que anule ou destrua a igualdade. O que, aliás, não deixa de ser um reflexo da conotação popular geralmente negativa dada ao epíteto ${ }^{268}$. Segundo Dom Paulo Evaristo Arns, “discriminar é excluir, é negar cidadanias e a própria democracia"269. Segundo o Manual de capacitação $e$ informação sobre gênero, raça, pobreza e emprego da Organização Internacional do Trabalho, "discriminação é o ato de tratar as pessoas de forma diferenciada e menos favorável a partir de determinadas características pessoais, tais como, entre outras, o sexo, a raça, a cor, a origem étnica, a classe social, a religião, as opiniões políticas, a ascendência nacional, que não estão relacionadas com os méritos e nem com as qualificações necessárias ao exercício do trabalho" 270.

${ }^{266}$ Action d'isoler et de traiter différemment certains individus ou un groupe entier par rapport aux autres (MERLET, Philippe (diréction générale). Le petit larousse illustré. 100em édition. Montreal, 2004, p. 370).

267 Segundo Maria Helena Diniz, discriminação "Na linguagem jurídica em geral, indica: a) ato de separar uma coisa que está unida a outra; b) separação entre coisas, cargos, serviços, funções ou encargos iguais, similares ou diferentes; c) definição; d) limitação decorrente da individuação da coisa; e) classificação de algo fazendo as devidas especificações; f) tratamento preferencial de alguém, prejudicando, outrem; situação subjetiva de tratamento diferenciado em relação a uma qualidade da pessoa, como sexo, raça, idade etc., lesiva a um interesse econômico, social, moral, profissional (Alice Monteiro de Barros); h) qualquer distinção, exclusão ou preferência que anule ou destrua a igualdade. (Dicionário jurídico. 2 volume. $2^{\mathrm{a}}$ Edição. São Paulo: 2005, p. 221, grifos do autor)

${ }^{268}$ Analisando o tema Francisco Gérson Marques de Lima, destacou o vocábulo discriminação "tem, na órbita empírica, afeiçoado conotação pejorativa, ultrapassando e indo além do sentido de, simplesmente, ato de discriminar, distinção, separação etc. O uso popular, por força da evolução natural da língua, temlhe imposto, em acréscimo, o emprego de locuções e expressões adjetivadas ou adjetivadoras, mesmo implicitamente, de tal modo que, hoje discriminação tem sentido de ato de discriminar ou diferenciar com peoração, sem pertinência lógica ou preconceituosamente, para eliminar o indivíduo ou o objeto analisado mediante mero raciocínio subjetivo; distinção feita entre pessoas ou objetos, eliminando uns em beneficio de outros, para satisfazer anseios e idéias preconcebidas; separação através de tirocínio sem balizamento objetivo; discernimento feito por alguém, que leva o individuo ou o objeto distinguido à situação de inferioridade, embora, antes, fossem uns e outros iguais ou semelhantes entre si"'(LIMA, Francisco Gérson Marques de. Igualdade de tratamento nas relações de trabalho. Anotação à Lei 9.029/95 em confronto com as Leis ns. 9.263/96, 7.716/89, 7.437/85 e 9.459/97 (aspectos trabalhistas e penais).São Paulo, Malheiros, 1997, p. 33, grifos do autor).

269 ARNS, Cardeal Dom Paulo Evaristo. Para que todos tenham vida. In: Discriminação: estudos. Viana, Márcio Túlio e Renault, Luiz Otávio Linhares (coord). São Paulo: LTr, 2000, p. 13.

270 ORGANIZAÇÃO INTERNACIONAL DO TRABALHO (OIT). Manual de capacitação $e$ informação sobre gênero, raça, pobreza e emprego: guia para o leitor, v.2. Brasília, OIT, 2005, p. $53 / 54$. 
A conotação predominantemente pejorativa do epíteto discriminação vem, contudo, se modificando conforme vão se consolidando no direito brasileiro os estudos acerca das ações afirmativas. Isto porque o referido epíteto denota o conjunto de medidas legais, políticas sociais e programas instituídos com a finalidade de corrigir as desigualdades e promover a igualdade de oportunidades ${ }^{271}$, possui como sinônimo no direito brasileiro a expressão discriminação positiva. A duplicidade de epítetos decorre do fato de parte dos estudiosos do tema preferir utilizar uma versão brasileira para a expressão affirmative actions, utilizada pela doutrina norte-americana, e parte preferir a adaptação do termo francês discrimination positif. $\mathrm{O}$ fato é que, com a incorporação ao direito brasileiro desta última expressão, o termo discriminação deixou de ter uma conotação exclusivamente pejorativa, denotando também ações louváveis que visam justamente corrigir a desigualdade de forças decorrente de diferenças biológicas ou sócio-culturais.

Outro termo que importará ao nosso estudo, por dele resultar grande parte das condutas discriminatórias, é preconceito, expressão que, segundo o Manual de capacitação e informação sobre gênero, raça, pobreza e emprego: guia para o leitor da Organização Internacional do Trabalho, contrapõe-se à racimos, na medida em que este denota a ideologia que apregoa a existência de uma hierarquia entre grupos raciais e aquele denota uma idéia preconcebida, isto é, um conceito ou opinião formada antecipadamente, a priori, uma predisposição negativa dirigida a pessoas, grupos de pessoas ou instituições sociais ${ }^{272}$. Para Francisco Gérson Marques de Lima, "o preconceito resulta da internalização de crenças e idéias preconcebidas e denota um sentimento, que acarreta uma postura do indivíduo chamado preconceituoso" 273 . Seria isto, aliás, que o diferenciaria da expressão discriminação que para ele nada mais seria do que o lado ativo do preconceito, "a própria atitude do indivíduo na exteriorização do sentimento, saltando do campo da

\footnotetext{
${ }^{271}$ CARLOS, Vera Lúcia. Op. cit., p. 28.

272 ORGANIZAÇÃO INTERNACIONAL DO TRABALHO (OIT). Manual de capacitação e informação sobre gênero, raça, pobreza e emprego: guia para o leitor, v.2. Brasília, OIT, 2005, pp. $53 / 54$.

${ }^{273}$ LIMA, Franciso Gérson Marques de. Op. cit., pp. 38/39.
} 
postura, podendo consistir em um ou mais atos que diferenciam os indivíduos ou as coisas ${ }^{274}$.

José Cláudio de Brito Filho, por sua vez, destaca que o preconceito apesar de censurável não produz efeitos jurídicos, enquanto não for exteriorizado, transformando-se, portanto, em discriminação ${ }^{275}$.

Outro termo que guarda estreita relação com o objeto do presente estudo é estereótipo. Segundo o Manual de capacitação e informação sobre gênero, raça, pobreza e emprego: guia para o leitor da Organização Internacional do Trabalho, estereótipo é a reprodução fiel de algo que o torna fixo e inalterável, referindo-se, em geral, às marcas dadas aos indivíduos, desde os padrões estéticos até os comportamentos. Como exemplo, o trabalho do organismo internacional destaca a tendência de qualificar os negros por meio de atributos que os situariam no pólo negativo, oposto àquele em que os brancos estariam situados. Ex.: sujo versus limpo; ignorante versus inteligente; submisso versus orgulhoso etc. ${ }^{276}$. São, em verdade, frutos de uma generalização apressada, na qual se toma como verdade universal algo que foi observado em um ou em alguns indivíduos, o que, em muitos casos, se torna fator de grandes injustiças.

Estereótipo e preconceito diferenciam-se por ser aquele predominantemente um produto cultural, diretamente ligado ao meio social, e variável nas diversas sociedades, enquanto este se constitui, mormente, em uma reação individual. Outro não parece ser o entendimento de José Cláudio Monteiro de Brito Filho, segundo quem restam dois fatores a influenciar a percepção, um de natureza subjetiva, que resultaria de uma predisposição de natureza psicológica à avaliação

\footnotetext{
${ }^{274}$ Ibidem, pp. 38/39.

${ }^{275} \mathrm{O}$ preconceito, por outro lado, muito embora sua conceituação seja necessária, não pode ser considerado propriamente como categoria jurídica de análise, pois ele, apesar de encerrar atitude negativa, não produz efeitos para o Direito.

Por que não? Porque, o preconceito, embora condenável, não atenta contra direitos subjetivos, salvo quando se exterioriza, em forma de discriminação - e aqui em qualquer forma ou grau (BRITO FILHO, José Cláudio Monteiro de. Discriminação no trabalho. São Paulo: LTr, 2002, p. 40).

${ }^{276}$ ORGANIZAÇÃO INTERNACIONAL DO TRABALHO (OIT). Manual...op. cit., v.2, pp. 53/54.
} 
negativa, outro, de natureza objetiva, cultural, decorrente da educação que recebemos e transmitimos ${ }^{277}$.

A distinção entre preconceito, estereótipos e discriminação mostra-se relevante até mesmo para a definição da estratégia a ser adotada. Com efeito, estudos da Organização Internacional do Trabalho dão conta de que "Uma ação educativa e persuasiva pode contribuir para a diminuição do preconceito e para a revisão dos estereótipos, levando à valorização das diferenças e da diversidade". O mesmo não se podendo afirmar em relação à discriminação que, por se tratar de uma prática, necessita também ser combativa mediante a utilização de dispositivos legais para que se tenha alteração no quadro das desigualdades ${ }^{278}$.

Outro equívoco terminológico freqüentemente utilizado é a designação dos grupos normalmente objeto de práticas discriminatórias, tais quais negros, mulheres e homossexuais, de "minorias" ou "grupos minoritários". Estudos da Organização Internacional do Trabalho demonstram, por exemplo, que negros e mulheres somados representam a maior parte da população economicamente ativa no Brasil $^{279}$.

Melhor, então, chamar estes grupos de desfavorecidos e não de "minorias", vez que esta expressão não denota a sua real participação no mercado de trabalho.

\footnotetext{
${ }^{277}$ BRITO FILHO, José Cláudio Monteiro de. Op. cit., pp. 97/98. O legislador brasileiro não primou por uma precisão técnica ao tratar desta questão, desprezando os ensinamentos já conseguidos nesta matéria por outras ciências confusão entre os referidos conceitos. Como salienta Kátia Elenise Oliveira da Silva, "As leis penais que disciplinam a matéria, em muitas oportunidades utilizam os conteúdos da discriminação, do racismo e do preconceito como sinônimos" (SILVA, Kátia Elenise Oliveira da. $O$ papel do direito penal no enfrentamento da discriminação. Porto Alegre: Livraria do Advogado Editora, 2001, p. 15).

${ }^{278}$ ORGANIZAÇÃO INTERNACIONAL DO TRABALHO (OIT). Manual...op. cit., v.2, p. 55 .

${ }^{279}$ A desigualdade e a discriminação de gênero e raça no Brasil não são fenômenos referidos a "minorias" ou a grupos específicos da sociedade. As mulheres e os/as negros/as representam, respectivamente, $42 \%$ e $44,5 \%$ da População Economicamente Ativa (PEA) brasileira (ou seja, quase a metade, em ambos casos). Somados, correspondem a 55 milhões de pessoas, que representam a ampla maioria (68\%) da PEA no Brasil: 36 milhões de negros de ambos os sexos e quase 19 milhões de mulheres brancas. ORGANIZAÇÃO INTERNACIONAL DO TRABALHO (OIT). Manual...op. cit., v.1, p. 38 .
} 


\subsection{TIPOS DE DISCRIMINAÇÃO}

Como bem observam Octávio Bueno Magano e Estêvão Mallet, "a discriminação se exterioriza de diversas formas, mas pode ser agrupada em quatro classes: direta, indireta, negativa e positiva" ${ }^{, 280}$. Convém esclarecer, embora a sua literalidade já conduza a esta conclusão, que a primeira expressão mencionada se contrapõe à segunda, e à terceira à quarta, de modo que se pode ter uma discriminação direta positiva ou negativa, assim como uma discriminação indireta positiva ou negativa. Jamais, porém, uma discriminação simultaneamente direta e indireta ou negativa e positiva.

Segundo Vera Lúcia Carlos, tem-se discriminação direta quando se estabelece um tratamento desigual fundado em razões arbitrárias e desmotivadas, e indireta quando se confere um tratamento formalmente igual, mas que, no resultado, se traduz em efeito diverso sobre determinados grupos, acarretando desigualdade. Como a referida autora cuida de esclarecer, esse tipo de discriminação consiste em uma conduta (regra) que embora a primeira vista aparente ser neutra e aplicada igualmente a todos os empregados, mas que, melhor analisando, produz efeito discriminatório para um empregado ou um grupo de empregados ${ }^{281}$.

Octávio Bueno Magano e Estêvão Mallet, exemplificaram afirmando que a discriminação direta se verifica quando o empregador adota a diretriz de não admitir mulheres a seu serviço e a indireta quando certos setores da economia se mostram estruturados de forma a favorecer o emprego de homens ${ }^{282}$.

Nos dias de hoje, em que já se consagrou o repúdio às condutas discriminatórias, é natural que a discriminação indireta seja bem mais freqüente do que a direta. Como salienta Christiani Marques, é comum "ser negada a oportunidade de trabalho fundamentada em motivo irreal, para que não se alegue uma

\footnotetext{
${ }^{280}$ MAGANO, Octávio Bueno e MALLET, Estêvão. O direito do trabalho na Constituição. Rio de Janeiro: Forense, 1993, p. 165.

${ }^{281}$ CARLOS, Vera Lúcia. Op. cit., p. 31.
} 
conduta de discriminação, quando na realidade o que impede o acesso ao emprego são motivos aparentes, muitos deles substanciados nos fatores subjetivos" ${ }^{\text {283 }}$. Usualmente este comportamento censurável vem seguido de desculpas polidas, evasivas e gentis.

Discriminação negativa, por sua vez, poderia ser definida como toda diferenciação arbitrária e injustificável, que não vise diminuir as diversidades sociais e econômicas, criando, ao contrário, desfavorecimentos injustificáveis. Como salienta Vera Lúcia Carlos, "Trata-se da concepção da igualdade jurídica em sentido subjetivo e pessoal, estabelecendo um desfavor à pessoa discriminada" 284 .

Discriminação positiva, por sua vez, consiste na diferenciação feita para compensar juridicamente a desvantagem material que determinada pessoa ou grupo possui, seja em decorrência de fatores naturais ou históricos. Como bem ressalta Vera Lúcia Carlos, "a discriminação negativa é ilícita, pejorativa, pois cria um desfavor à pessoa discriminada, e se distingue da discriminação positiva, lícita, que tem a finalidade de assegurar a igualdade real, dando origem às chamadas ações afirmativas" 285 .

Uma vez mais se mostram elucidativos os exemplos de Magano e Mallet, segundo quem a discriminação negativa é a que resulta da recusa do trabalho de mulheres e a positiva é a que as favorece, como ocorreria com a companhia de aviação que só admitisse aeromoças a seu serviço ${ }^{286}$.

\subsection{CATEGORIAS DA DISCRIMINAÇÃO SEGUNDO O DIREITO AMERICANO.}

\footnotetext{
${ }^{282}$ MAGANO, Octávio Bueno e MALLET, Estêvão. Op cit, p. 167.

283 MARQUES, Christiani. Op. cit., p. 38.

${ }^{284}$ CARLOS, Vera Lúcia. Op. cit., , p. 32.

${ }^{285}$ CARLOS, Vera Lúcia. Discriminação nas relações de trabalho. São Paulo: Editora Método, 2004, p. 33.

${ }^{286}$ MAGANO, Octávio Bueno e MALLET, Estêvão. Op. cit., p. 166.
} 
Segundo Bárbara Lindemann Schlei e Paul Grossman, existem quatro categorias ou teorias gerais da discriminação que são listadas na ordem de seu desenvolvimento histórico: (1) tratamento diferenciado; (2) políticas ou práticas que se perpetuam na presença de efeitos de discriminações passadas; (3) discriminação por impacto (políticas e práticas que tem um impacto adverso não justificado pela necessidade comercial); (4) fracasso ao acomodar racionalmente as práticas e opções religiosas de um empregado ${ }^{287}$. Para os referidos doutrinadores norte-americanos, todos os casos de discriminação no trabalho deveriam ser analisados dentro de uma ou mais destas teorias.

Um exemplo da primeira teoria seria a recusa absoluta em considerar negros para o emprego, pagar menos para uma mulher do que o que é pago para um homem pelo mesmo trabalho ou, no caso americano, dispensar alguém de ascendência latina por uma infração punida menos severamente quando perpetrada por alguém de origem anglo-saxônica ${ }^{288}$.

Já com relação à segunda teoria, um exemplo clássico é a instituição de uma estrutura departamental composta por setores de desejabilidade variável e os empregados que integram minorias são enviados apenas para aqueles setores menos desejados e atrativos ${ }^{289}$.

A terceira teoria pode ser exemplificada pelos testes de inteligência geral como pré-requisito para contratação que desqualificam substancialmente mais negros do que brancos e que não possuem relação direta com as

287 There are four general categories or theories of discrimination, which are listed in order of their historical development: (1) disparate treatment, (2) policies or practices which perpetuate in the present the effects of past discrimination, (3) policies or practices having an adverse impact not justified by business necessity, and (4) failure to make reasonable accommodation to an employee's religious observance or practics (SCHLEI, Barbara Lindemann. Employment Discrimination Law. Second Edition. Chicago: American Bar Association, 1983, p.1).

${ }^{288}$ Examples include an absolute refusal to consider blacks for employment, paying a woman a lower wage than paid a man for the same work, and discharging a Spanish-surnamed employee for an offense for which Anglos are given lesser or no discipline. (Ibidem, p. 1)

289 A classic example is a departamental seniority structure where the employer hired minorities only into the least desirable departments, and thereafter either flatly barred transfers between the departments or required a forfeiture of seniority as a condition of transfer, a minority employee would be effectively locked into an undesirable department, in which he had originally been placed as a consequence of discrimination. The legality of the seniority structure would then depend on whether it was "bona fide". (Ibidem, p.1) 
atividades para a qual será contratado o empregado. Outros exemplos seriam o requerimento de um diploma do ensino médio como pré-requisito para contratar menos negro do que branco se esta formação não for indispensável para o trabalho a ser desempenhado ${ }^{290}$.

Por fim, exemplificando a quarta teoria os autores mencionam a dispensa de um judeu por se recusar a trabalhar no sábado onde a adaptação das práticas religiosas do empregado não gerem maiores obstáculos na conduta do negócio do empregador ${ }^{291}$.

Haja vista não serem corriqueiros os casos de discriminação envolvendo orientação religiosa no Brasil, pelo menos no tocante às relações de trabalho, cumpre, então analisar mais acuradamente as outras três formas de discriminação aduzidas.

\subsubsection{TRATAMENTO DIFERENCIADO.}

Segundo Paulo Jakutis, sob essa denominação encontra-se a maioria dos casos de discriminação no direito estadunidense, assim como a maioria dos casos da jurisprudência brasileira. Contudo, segundo ele pôde constatar, nos Estados Unidos exige-se a necessidade da intenção de discriminar, o que é prescindível nos conflitos ocorridos no Brasil por assim não dispor a legislação local $^{292}$.

${ }^{290}$ Examples include (1) as general intelligence test as a prerequisite for hire which disqualifies substantially more blacks than whites and which cannot be shown to be job-related in the sense that it accuratelly predicts successful job performance; (2) a requiremente of a high school diploma as a prerequisite for hire where fewer blacks than whites have such a diploma and the diploma cannot be shown to be job-related (Ibidem, p. 1)

${ }^{291}$ An example would be discharging a Sabbatarian for refursing to work on the Sabbath where an accomodation to the employee's religious practice would not work an undue hardship on the conduct of the employer's business(Ibidem, p. 1).

292 JAKUTIS, Paulo. Manual de estudos da discriminação no trabalho: estudos sobre discriminação, assédio moral e ações afirmativas, por meio de comparações entre o direito do Brasil e dos Estados Unidos. São Paulo: LTr, 2006, p. 129. 
Nesta categoria de discriminação o empregador simplesmente trata algumas pessoas menos favoravelmente do que outras em razão de sua raça, cor, religião, sexo ou origem natural. A prova do motivo da discriminação é flagrante, embora em algumas situações possa ser inferida pela forma como se dão as diferenças de tratamento ${ }^{293}$.

A essência do tratamento desigual é a existência de desigualdade na forma de tratamento entre duas pessoas. Não importa se o tratamento é melhor ou pior, conquanto seja ele diferente. Um exemplo clássico é a existência de instalações segregadas. Por outro lado não importa se o empregado é um bom ou um mal empregado ou se o empregador é justo ou injusto.

Paulo Jakutis identifica no seguinte julgado do Tribunal Regional do Trabalho da $3^{\mathrm{a}}$ Região uma hipótese de discriminação por tratamento diferenciado:

DISCRIMINAÇÃO NAS RELAÇÕES DE TRABALHO RAÇA NEGRA - Por direito e lei, é firmemente repudiado em nosso país, qualquer ato de discriminação em função de cor, raça, sexo idade, religião ou condições especiais e individuais que diferencie a pessoa. Nas relações de trabalho, especialmente, não se podem tolerar atos discriminatórios e humilhantes impingidos ao empregado de raça negra, com ofensas verbais assacadas contra sua pessoa em função exclusiva da cor de sua pele. Fato como tais devem ser denunciados, sempre, a fim de que não se torne comum e usual a violação de um direito garantido constitucionalmente, reforçando preconceito e prática discriminatória inaceitável. $\mathrm{RO}$ a que se dá provimento para fixar indenização por danos morais, em função da violação da honra e do sentimento de dignidade própria do empregado, que, como qualquer outra pessoa, merece apreço e respeito de seus superiores hierárquicos, não podendo aceitar ou resignar-se com frases como "negro safado", "crioulo", ou "se voltasse a escravidão eu ia te colocar no tronco". O dano moral, íntimo, é irreparável, mas o ato discriminatório pode e deve ser estancado por esta Justiça.TRT $3^{\text {a }}$ Região. $1^{\text {a }}$ Turma. RO n. 5207/1999

293 "disparate treatment" is the most easily understood type of discrimination. The employer simply treats some people less favorably than others because of their race, color religion, sex or national origin. 1519 (1977) In: SCHLEI, Bárbara Lindemann. Op. cit., p. 13).
} 
Publicado no DJMG em 19-05-2000, pg 08, relator Juiz Washington Maia Fernandes.

Segundo Paulo Jakutis, o abuso verbal, pelo qual o trabalhador sofre ofensa do empregador ou de quem o represente, talvez seja a forma de discriminação mais facilmente encontrada na jurisprudência brasileira ${ }^{294}$.

\subsubsection{POLÍTICAS OU PRÁTICAS QUE SE PERPETUAM NA PRESENÇA DE EFEITOS DE DISCRIMINAÇÕES PASSADAS.}

Nos Estados Unidos, segundo assevera Barbara Lindeman Schlei, alguns empregadores discriminavam grupos minoritários relegando a estes empregos relativamente inferiores. Uma das formas utilizadas para fazê-lo era mediante a apresentação de sistemas de senioridade aparentemente neutros, mas que no fundo escondiam discriminações odiosas. A ascensão no plano de carreira seria medida pela antiguidade no departamento e não em geral dentro da empresa. Nessas indústrias os critérios de antiguidade para fins de ascensão nos planos de carreira eram organizados de modo a que atividades que exigissem maiores habilidades fossem agrupadas em determinado setor e as atividades que exigissem menos habilidades fossem em outro, cada uma com contagem e benefícios próprios de antiguidade, os quais não seriam transportados para outro setor, em caso de mudança. Em outras palavras, se empregados com muitos anos de serviços prestados em um grupo cujos seus direitos de senioridade estavam estipulados em uma forma de baixo pagamento pleiteassem mudança para um setor onde ficavam os empregados com mais habilidades e proteção, perderiam eles seus direitos e proteções. Desta feita, eles ficariam eternamente em desvantagem em relação ao grupo que sempre ocupou aqueles postos no que se refere à competição pelos melhores postos de trabalho e as proteções contra dispensa $^{295}$. Em suma, o plano de carreiras era elaborado justamente para possibilitar

\footnotetext{
${ }^{294}$ JAKUTIS, Paulo. Op. cit., p. 132.

295 "Some employers, particularly prior to the passage of Title VII, discrimininated against protected groups by assigning them to relatively inferior employment. Many such companies also had a facially neutral seniority systems which restricted transfer, such as a departamental senority systems rather than plantwide seniority systems. In many industries those systems were organized so that related skilled jobs
} 
que os grupos desfavorecidos tivessem acesso a melhores postos de trabalho, desde que para fazê-los abdicassem de seus direitos de senioridade. Ou seja, cria-se um benefício para qual o acesso traz um encargo tão alto, por vezes desvantagens que anulam a vantagem que poderia ser auferida, que os integrantes dos grupos desfavorecidos acabam, por óbvio, optando por não pleitear mudanças, eternizando-se assim a discriminação.

would be grouped into the same department and unskilled jobs would de included in a separate department. This meant that long-service members of a protected group who had established substantial seniority rights in a low- paying, unskilled department would lose those departamental seniority rights or protections should they transfer to the skilled, higher paying, more deisrable department. They would forever be in disadvantage relative to more recently hired majority group members with respect to competition for jobs and protections against layoff in the more desirable jobs. One of the early issues subsequent to the effective date of Title VII was the legality of such system (SCHLEI, Bárbara Lindemann. Op. cit., p. 23). On the basis of a literal reading of the pertinent provisions of the Act, it was originally contented that if an employer ceased and ad all discriminatory practices with respect to hiring, transfers, and/or promotions on the effective date of the Act and had a seniority system which was facially neutral, such system was protected under $\S 703$ (h) as "a bona fide seniority system".

This contention was rejected by a line of cases beginning in 1968with Quarles v. Philip Morris, Inc. (279 F.Supp. 505, 1 FEP 260 (E.D. Va 1968). Quarles originated the category of discrimination known as perpetuation in the present of the effects of past discrimination, holding that a seniority and transfer system constituted presente discrimination and violated Title VII if it locked members of a previously discriminated-against protected group into inferior positions in which they had originally been placed as result of discrimination which was itself beyond the reach of the court. Quarles resounding conclusion as to the intent of Congress with respect to facially neutral seinority systems which locked minorities into such positions was: "Congress did not intend to freeze an entire generation of Negro employees into discriminatory patterns that existed before the act.”(Id. At 516, 1 FEP at 269) The remey in Quarles was that all blacks hired before a particular date who were locked into undesirable departments, taking with them full employment seniority (Id. At 520-21, 1 FEP at 273).

The year following Quarles brought the landmark decision of Papermakers, Local $189 \mathrm{v}$. United States, (Id. At. 520-21, 1 FEP at 273) in which the Fifth Circuit was asked to consider whether, under Title VII, it was sufficient for a company with a formely discriminatory seniority system (i.e., one in which race, ex, or national origin determined departmental or progression-line assignment) simply to stop overt discrimination on and after the effective date of the Act. Quarles had dealt with the classic departmental or progressin-line assignment) simply to stop overt discrimination on and after the effective date of the Act. Quarles had dealt with the classic departmental seniority situation. Papermakers dealt with a Southern paper mill which was rigidly segregated on the bases of race until 1964, primarily throught the use of segregated progression lines whithin each department. In 1966, the black and white progression lines within sigle departments were merged on the basis of pay. This, with one minor exception, placed all black jobs in each department beneath all the white jobs in the same department. Racial restrictions in all departments were abandoned, and black employees were permitted to transfer to the entry position in the progression ladder of any department.

As a result of theses changes, some progression lines became racially integrated. But since black progression lines were merged beneath related white progression lines, and since upon transferring into a new department black employees went to the bottom of the progression ladder, the black employees went to the bottom of the progression ladder, the black employees were lower on the integrated progression ladders the white employees who were often many years their junior in terms of total length of service with the company (plant seniority). Moreover, under long-standing preiling seniority rules, promotions within a progression line were made step by step on the basis of seniority in the job classification. The result was that senior black employees were permanently ranked behind junior white employees for the purpose of promotion and/or transfer. The Court hold that they perpetuated pre-Act discrimination, a position that, consistent whith Quarles was to be state of the law from 1969 until 1977 when the Supreme Court decided Teamsters v. United States(431 U.S. 324, 14 FEP 1514 (1977)). (SCHLEI, Bárbara Lindemann. Op. cit., pp. 23/25). 


\subsubsection{DISCRIMINAÇÃO POR IMPACTO ADVERSO.}

Como reiteradamente destaca Paulo Jakutis em sua obra, no direito brasileiro, em decorrência da subscrição da Convenção n. 111 da OIT, não se exige a comprovação da intenção de discriminar para que a discriminação se caracterize. Em decorrência disto, o ordenamento tupiniquim veda também os atos que, embora não tenham, em uma primeira análise, a intenção de discriminar, criem impacto discriminatório $^{296}$.

Um das grandes dificuldades em se combater esse tipo de discriminação consiste justamente no fato de ser ele um conceito difícil de ser aplicado. Afinal, como observa Jakutis, "As dificuldades começam com a procura de um critério que permita concluir quando a prática, superficialmente neutra, é efetivamente discriminatória" ${ }^{297}$. E exemplifica com a polêmica envolvendo os testes padronizados:

\footnotetext{
${ }^{296}$ JAKUTIS, Paulo. Op. cit., p. 127.

${ }^{297}$ Ibidem, p. 127.
}

Para que a hipótese fique mais clara, pense no caso do "teste padronizado". Qual o resultado que leva a crer que um teste para admissão de empregador, ou mesmo para admissão em uma universidade, é discriminatório? Se todos os alunos negros forem reprovados, parece difícil não concluir que o exame tem alguma coisa que discrimina, por alguma razão, a população negra. Mas e se $80 \%$ dos alunos negros forem reprovados e $50 \%$ dos brancos também? Se, dentre os candidatos aprovados, tivermos uma percentagem de apenas $10 \%$ de mulheres de ambos os grupos (brancas e negras)?

Em verdade, as indagações deveriam partir de um ponto anterior àquelas elaboradas no parágrafo precedente. $\mathrm{O}$ correto seria começar perquirindo se, para os padrões brasileiros, seria aceitável a constatação da existência e discriminação apenas com base em dados estatísticos dos diferentes grupos que participaram dos testes seletivos, ainda que estes fossem tremendamente discrepantes $(90 \%$ de aprovação para um grupo e $5 \%$ para outros dois). Se a resposta fosse negativa, como se poderia, então, comprovar 
a existência do impacto desigual (talvez essa seja a grande questão que envolve esse tema) ${ }^{298}$ ?

Suas assertivas, como se vê, suscitam dois questionamentos. O primeiro, acerca da utilização de testes padronizados como instrumentos discriminatórios. O segundo, sobre a validade do uso das estatísticas como meio de prova nas ações em que se discute discriminação nas relações de emprego.

Os testes padronizados, chamados em inglês scored tests, vêm sendo usados pelos empregadores como instrumentos de seleção há muito tempo, como destaca Barbara Lindemann Schlei. Eles são atrativos para o empregador por servir de base para a identificação daqueles candidatos que aparentam melhor qualificação para um emprego em particular, além de remover parte da subjetividade que, de outra forma, permearia o processo seletivo ${ }^{299}$.

Estes testes ganharam importância no decorrer do século passado, e o seu crescimento veio acompanhado e encorajado pela expansão da psicologia educacional e industrial. Em decorrência deste fato, nos últimos anos os profissionais desta área vem desempenhando papel de destaque no desenvolvimento e explicação dos procedimentos de seleção de pessoal que visam escolher quais candidatos tem maior possibilidade de ter atender ao que espera o empregador. E assim, a elaboração e execução dos testes de seleção de empregados vêm se tornando um campo extremamente sofisticado e técnico, com linguagem própria, padrões próprios e metodologia própria e complexa ${ }^{300}$.

Nos Estados Unidos, há uma preocupação crescente com a possibilidade dos testes serem desvirtuados e utilizados para mascararem

${ }^{298}$ Ibidem, p. 127.

299 Scored tests have long been one of the employee selection devices used by employers. They are attractive to employers as a basis for identifying those candidates who appear to be the most qualified for the particular job, while at the same time they remove some of the subjectivity which may otherwise play a large part in employee selection decisions. (SCHLEI, Bárbara Lindemann. Op. cit., p. 80).

300 Such tests have been increasingly used in the twentieth century, and the growth has been accompanied (and no doubt encouraged) by the expansion of educational and industrial psychology. For years professionals in these fields have played a major role in the development and application of personel selection procedures that attempt to predict which candidates are more likely to succeed or fail 
comportamentos discriminatórios. A jurisprudência da Suprema Corte norte-americana, no paradigmático julgado Guardians Ass'n of the New York City Police Dep't v. Civil Serv. Comm'n, 630 F.2d 79, 89, 23 FEP 909, 918 (2d Cir. 1980), destacou que embora o direito não possa ignorar tudo o que se aprendeu sobre os testes de recrutamento de pessoal, a ciência que os estuda e elabora não é tão precisa quanto a física ou a química $^{301}$. Desta feita, os testes padronizados podem ser intencionalmente usados para discriminar, e quando isso ocorre, as queixas, em geral, se baseiam muito mais na discriminação por impacto adverso do que em tratamento diferenciado ${ }^{302}$.

O papel da jurisprudência nestes casos deve ser analisar os testes de recrutamento de empregados, sua correlação com a vaga que se pretende preencher com essa seleção e com o resultado obtido. Essa análise é eminentemente

on the job. As a result, employment testing has developed into a highly sophisticated and technical field, with its own language, its own standards, and its own often complex methodology. (Ibidem, p. 81)

${ }^{301}$ Title VII and related fair employment statutes have required courts to consider the possibility of improper bias in the use of such tests for employees selection. The law in turn has looked to industrial psychology to assess whether a test is indeed a color - or sex-neutral predictor of successful job performance. As the Second Circuit noted, while the "study of employment testing has necessarily been adopted by the law as a result of Title VII, it is not a primarily legal subject:

"It is part of the general field of educational and industrial psychology, and possesses its own methodology, its own body of research, its own experts, and its own terminology. The translation of a thecnical study such as this into a set of legal principles requires a clear awareness of the limits of both testing and law. It would be entirely inappropriate for the law to ignore what has been learned about employment testing in assessing the validity of these tests. At the same time, the science of testing is not as precise as physics or chemitry, nor its conclusion as provable. While courts should drawn upon the findings of experts in the field of testing, they should not hesitate to subject these findings to both the scrutinity of reason and the guidance of congressinal intent." (Guardians Ass'n of the New York City Police Dep’t v. Civil Serv. Comm'n, 630 F.2d 79, 89, 23 FEP 909, 918 (2d Cir. 1980). (Ibidem, p. 81).

${ }^{302}$ Althought scored tests can be intentionally used to discriminate, as a pratical matter such cases are rare. By their nature tests at least purport to be objective selection devices, and normally generate claims of adverse impact, rather than disparate treatment. Accordingly, tests claims may arise in Title VII and possibly in Age Discrimination in Employment Act of 1967 (ADEA) and Rehabilitation Act of 1973 ("handicapped) cases, but absent proof of itentional dicrimination in the use of a test, scored tests will not be an issue in constitucional or $\S 1981$ actions (General Bldg. Contractos Ass'n, Inc. v. Pennsylvania, 457 U.S., 29 FEP 139 (1982) (proof of intent to discriminate necessary to establish a claim under $\S$ 1981). (Ibidem, pp. 82/83)

Analyses of testing cases begins with the seminal adverse impact analysis of Griggs v. uke Power Co. In that landmark decision the Supreme Court held that the "touchstone" of Title VII's proscription of employment selection devices that are "fair in form, but discriminatory in operation" is "business necessity": "If an employment practice which operates to exclude Negroes cannot be shown to be related to job performance, the practice is prohibited." Under Giggs, once the plaintiff has shown that the test in question "operate[s] to disqualify Negroes [or other protected groups] at a substantially higher rate" than their counterparts, the burden shifts to the employer to show that the test "bear[s] a demonstrable relationship to succesful performance of th jobs for which it was used." (Id) (Ibidem, p. 83)

In reaching this conclusion that a test having substantial adverse impact is prohibited absent proof of jobrelateness, the Supreme Court considered the defendant's claim that the tests in question were legal under Title VII's express authorization of the use of "any professionally developed ability test that is not designed, intended, or used to discriminate(...)." After examining Title VII's legislative history, the Court concluded that this provision did not insulate scored tests from the job-relatedness requirement: (Ibidem, p. 83). 
casuística, razão pela qual não é prudente afirmar quais questões incluídas nestes procedimentos. Em todo caso, cumpre salientar que em geral testes relacionados com a área de conhecimento que será explorada no trabalho a ser exercido, como, por exemplo, perguntas sobre direito e processo do trabalho ou solicitação de elaboração de uma reclamação trabalhista ou de uma defesa em procedimento deste gênero, tendem a ser menos questionáveis do que aqueles que buscam estabelecer um perfil moral do candidato, como, v.g., os exames de caligrafia e perguntas sobre vida privada.

Feitas estas considerações, cumpre estudar agora a possibilidade de utilização de dados estatísticos com meio de prova em ações envolvendo discriminação no emprego.

No direito norte-americano, segundo leciona Barbara Lindeman Schlei, as estatísticas se transformaram em um crucial meio de prova nas ações coletivas. As provas estatísticas se transformaram em batalha de expertos, requerendo que o advogado que atue em ações envolvendo discriminação no trabalho conheça conceitos e técnicas de estatística como desvios de padrão, análises cohort, e casos de regressão múltipla. A referida autora chega a afirmar que a maioria dos Juízos Federais adere ao princípio de que "em casos envolvendo discriminação, as estatísticas falam muito e as Cortes as ouvem"303.

E isso não apenas em casos de discriminação por impacto adverso. No tocante à prova do tratamento desigual, a Suprema Corte NorteAmericana estabeleceu no caso Macdonnell Douglas Corp. v. Green 411 U.S. 792, 5 FED 965 (1973) uma ordem tripartite e alocação de prova para se estabelecer se existe ou não motivação discriminação. Segundo ela o querelante precisaria, primeiramente, estabelecer um prima facie case. Em seguida o réu precisa apresentar uma razão legítima, não discriminatória para suas ações. Finalmente, o autor precisaria demonstrar que essa razão

\footnotetext{
${ }^{303}$ In class actions, statistics have become the crucial form of evidence. Statistical proof in the complex employment discrimination class action has become a battle of experts, requiring the employment discrimination lawyer to become knowledgeable about statistical concepts and techniques such as standard deviaions, cohort analyses, and multiple regretion analyses. Most federal courts adhere to the the principle that "in cases concerning racial discrimination, 'statistics often tell much and the Court listen"” (Ibidem, p. 11).
} 
supostamente legítima e não-discriminatória seria um pretexto para mascarar um motivo ilegal $^{304}$.

Ainda na análise dos casos Macdonnell Douglas Corp. v. Green, a Suprema Corte Norte-Americana deixou claro que o ônus da prova permanece o tempo todo com o autor e que a única obrigação do réu é articular uma razão legítima, não-discriminatória. Não precisa, portanto, apresentar uma série de evidências de que a razão por ela alegada foi a verdadeira razão, ou que a pessoa escolhida era mais qualificada do que o réu ${ }^{305}$.

Segundo esta seqüência tripartite de alocação de prova, a grande maioria de causas é resolvida na terceira etapa, se o querelante pode ou não estabelecer se razão alegada pelo querelante para suas alegações é de fato um pretexto para justificar uma fraude. Há três categorias gerais de evidência que podem ser apresentadas pelas partes a evidência direta ou motivo, a evidência estatística e a evidência comparada $^{306}$.

Evidência direta de motivação discriminatória é hoje relativamente rara. As estatísticas por outro lado são muito importantes nas ações coletivas e pouco nas ações individuais de tratamento desigual. Empregadores com estatísticas catastróficas contra si podem prevalecer em ações individuais de tratamento desigual e vice-versa ${ }^{307}$.

\footnotetext{
${ }^{304}$ (Ibidem, p. 14).

${ }^{305}$ In a series of three post-MacDonell Douglas Corp. v. Green cases, the Supreme Court has made it clear that the burden of proof at all times remains with the plaintiffm, and that the employer's sole obligation at the second is simply to articulate a legitimate, nondiscriminatory reason rather than establishing by a preponderance of the evidence that its proffered reason was the real reason, or that the person selected was more qualified thant the plaintiff (Ibidem, p.14)

${ }^{306}$ In this tripartite order and allocation of proof, the great majority of cases will turn on the third stage, whether or not the plaintiff can establish that the defendendant's articulated reason for its actions is in fact pretext. There are three general categories of evidence that can be presented by the parties:

(1)direct evidence of motive;

(2)statistical evidence; and

(3)comparative evidence.(Schlei, 1983, p. 14).

${ }^{307}$ Direct evidence of discriminatory motivation is now rellative unusual. Statistics, all- important in class actions and adverse impact cases, are of relatively low importance in an individual disparate treatment case. Employers with damaging statistics can prevail in an individual disparate treatment case and vice versa (Ibidem, p 15)
} 
A chave seria, segundo Schlei e Grossman, normalmente evidência comparativa. $O$ querelante normalmente oferece uma comparação de tratamento entre integrantes de grupos protegidos e de grupos majoritários, argumentando que em situações semelhantes grupos minoritários foram tratados de forma menos favorável do que grupos majoritários. O réu, por outro lado, vai se defender argüindo que as comparações não eram apropriadas porque os indivíduos não estão em situações análogas ${ }^{308}$.

Analisando o direito americano, Firmino Alves Lima destaca ser a utilização de estatísticas um dos mais poderosos instrumentos na avaliação de atitudes discriminatórias, principalmente quando são investigadas situações de discriminação por efeito adverso ${ }^{309}$. Pondera, contudo, que, ao contrário do que parece, as questões envolvendo estatísticas não são assim tão fáceis de compreender e servir como prova irrefutável, pois tudo depende, e muito, da metodologia da estatística utilizada, e dos fatores de comparação utilizados, para se chegar a uma conclusão se há discriminação proporcional ${ }^{310}$. E descreve o caso Hazelwood School District v. United States como emblemático sobre os problemas que os critérios das estatísticas podem apresentar:

O governo Federal ajuizou a mencionada ação contra uma escola distrital no condado de Saint Louis, Missouri, alegando que ela estava engajada em um padrão de prática de discriminação no emprego de professores, em plena violação do Título VII, aplicáveis aos empregadores governamentais de acordo com a emenda de 24 e março de 1972. O juízo do distrito federal entendeu que o Governo não demonstrou o padrão de prática de discriminação. A Corte de apelações reverteu a decisão recorrida afirmando que a análise de dados estatísticos feita pelo Juízo de $1^{\circ}$ grau resultou em uma irrelevante comparação de professores negros em Hazelwood, com professores negros em todo o Condado de Saint Louis. No Condado 15,4\% dos professores disponíveis são negros, mas na escola, nos anos de 1972-1973 e 1973-1974 somente $1,4 \%$ e $1,8 \%$ os professores eram negros. Os fatos acima, adicionados às

\footnotetext{
${ }^{308}$ The key is usually comparative evidence. The plaintfull will normally offer a comparison of treatment between protected group members and majority group members, contending that comparably situated protected group members were treated less favorably than majority group members. The defendant will normally contend that the comparisons made by the plaintiff are inappropriate because the individuals are not comparably situated (Ibidem, p. 15).

${ }^{309}$ LIMA, Fimino Alves. Op. cit., p. 207.

${ }^{310}$ Ibidem, p. 208.
} 
práticas anteriores comprovadas nos autos, demonstravam ser um caso prima facie levando à inversão do ônus da prova.

A comparação feita pela Corte de apelações foi entendida como correta pela Suprema Corte, quando foi promovida a comparação entre os professores da escola e o público profissional qualificado para desempenhar a atividade de professor no mercado do condado em Saint Louis. A Suprema Corte entendeu que a Corte de Apelações equivocou-se apenas na consideração do feito como prima facie case posto que poderiam ser cotejados outros dados anteriores e posteriores à época envolvida, cabendo a possibilidade de produção de uma contraprova pela escola $^{311}$.

Analisando o referido julgado, Firmino Alves Lima observa que a Suprema Corte entendeu correta a comparação feita entre os professores da escola e o público profissional qualificado para desempenhar a atividade de professor no mercado do condado de Saint Louis pela Corte de apelações. Para a máxima instância da justiça norte-americana o equívoco da instância recorrida residiu tão somente na consideração do feito como prima facie haja vista que poderiam ser cotejados outros dados anteriores e posteriores à época envolvida, cabendo, outrossim, a possibilidade de uma contraprova pela escola ${ }^{312}$.

No direito brasileiro, há que se lamentar, os juízes ainda apresentam muita resistência quanto a aplicação de dados estatísticos como meios de prova. Em sentença prolatada em 09 de janeiro de 2006 nos autos da Ação Civil Pública ajuizada pelo Ministério Público do Trabalho em face de um importante conglomerado financeiro brasileiro brasileiro (tombada com o número 00928-2005014-10-00-5), naquele feito acusado de práticas discriminatórias em relação a sexo (As mulheres eram alegadamente discriminadas em matéria de ascensão funcional e de remuneração), bem como em relação à cor/raça (os negros supostamente seria discriminados quanto à admissão, ascensão e remuneração) e idade (trabalhadores com idade superior a 40 anos), práticas que o Ministério Público pretendia provar através de dados estatísticos, assim o juízo decidiu asseverando expressamente que "a gravidade da conduta imposta à reclamada não pode ser puramente aferida através de dados estatísticos até mesmo porque estes sofrem influência de inúmeras contingências”.

${ }^{311}$ Ibidem, pp. 208/209. Decisão disponível em <http://laws.findlaw.com/us/433/299.html> em 04 de fevereiro de 2007. 


\subsection{MOMENTO DA DISCRIMINAÇÃO}

Como destaca Eduardo Caamaño Rojo um ato discriminatório em matéria laboral pode se apresentar em qualquer das etapas do iter contratual: a) na chamada fase pré-contratual, quando se verifica a seleção de pessoal e se cuida dos atos preparatórios destinados a fixar o conteúdo e o alcance dos direitos e obrigações que decorrerão do contrato de trabalho que se pretende celebrar; b) durante a vigência da relação de emprego; ou c) no momento da rescisão do contrato de trabalho $^{313}$.

\subsubsection{DISCRIMINAÇÃO NA FASE PRÉ-CONTRATUAL}

É no momento da formação do contrato de trabalho que a diferença de forças entre empregador e empregado se verifica com maior intensidade. Em geral, tem-se de um lado um desempregado, ávido para obter um emprego que lhe assegure meios de subsistência, ou mesmo um empregado que anseia por um melhor posto de trabalho, e do outro um empregador com um extenso rol de possibilidades de escolha consistente nos interessados na vaga posta à disposição. Ademais, neste momento contratual o empregador goza de ampla liberdade para determinar quantos empregados contratará e até mesmo se efetivamente contratará alguém. Afinal, não há nada que imponha o empregador a escolher um dos candidatos que se apresentou, ou que simplesmente desista de aumentar o seu quadro de funcionários durante o período de recrutamento. O que não lhe é permitido é discriminar um ou alguns dos candidatos por motivos ilegítimos.

\footnotetext{
${ }^{312}$ LIMA, Fimino Alves. Op. cit., pp. 208/209.

${ }^{313}$ ROJO, Eduardo Caamaño. El derecho a la no discriminación en el empleo. Santiago: LexisNexis, 2005, p.101.
} 
Essa desigualdade de forças faz com que, não raro, muitos candidatos, embora qualificados, sejam preteridos apenas por não despertarem simpatia no empregador, seja porque ele é preconceituoso em relação a alguma conduta, seja porque entende que determinada característica estética pode causa maiores custos, seja porque seus clientes não aceitarão tal pessoa. Como se pode perceber, diversos motivos ilegítimos podem levar o empregador a discriminar candidatos a ocupar determinado posto vago.

Não fosse isso o bastante, um ato discriminatório praticado por ocasião da formação do liame empregatício mostra-se, em geral, mais difícil de provar do que um praticado durante ou ao término deste. A uma por ser bem mais fácil se encontrar alguém que testemunhou um ato discriminatório praticado durante a relação de emprego do que alguém que presenciou este ilícito ocorrendo no momento da formação do contrato. Em geral somente participam do processo seletivo salvo no caso das chamadas dinâmicas de grupo - o candidato e os entrevistadores. E não é de se imaginar que estes testemunhem sobre o ato discriminatório, haja vista serem no mínimo partícipes do ocorrido. A duas porque a idéia de que o empregador tem liberdade plena para contratar quem ele quiser ainda está muito arraigado em nossa cultura. A três porque ainda são poucas as pessoas que sabem que há formas de se combater este tipo de conduta. A quatro porque muitas vezes o discriminado nem chega a ter conhecimento que foi preterido por um motivo não legítimo.

Cumpre então esclarecer quando se está diante de uma discriminação no momento da formação do contrato de trabalho. Consoante leciona Christiani Marques, “a discriminação se manifesta de forma arbitrária nas condições de acesso ao emprego, quando a exigência de requisitos não é legitimada com o fim destinado" 314 . Em outras palavras, sempre que se excluir algum candidato do processo seletivo ou deixar de contratá-lo em decorrência de alguma característica sua que não o impossibilitasse para o exercício da função, nem tampouco o tornasse menos apto que os demais candidatos se estará praticando uma discriminação.

${ }^{314}$ MARQUES, Christiane. Op. cit., p. 41. 
Diversos são os modos como pode se operar a discriminação neste momento pré-contratual. Segundo Christiane Marques, como neste íter ainda não está presente a subordinação, elemento ínsito à relação de emprego, quaisquer perguntas que se desviem da finalidade da atividade profissional insinuam certa coação econômica, tendo em vista que o candidato seria indagado sobre fatos de sua vida privada, sem qualquer relação com suas aptidões profissionais. Afinal, esta forma de investigação, através de questionários ou entrevistas, constitui forte indício para a discriminação na futura relação de emprego ${ }^{315}$. Outrossim, mesmo um teste para recrutamento de pessoal poderá ser utilizado como instrumento para perpetrar uma conduta discriminatória quando os critérios utilizados para avaliação não analisarem efetivamente a aptidão para o desempenho da função postulada, permitindo apenas que o empregador, imbuído de preconceito, elimine candidatos que não lhe agradam por razões outras. Um outro exemplo, que infelizmente está se tornando comum de discriminação na fase pré-contratual, é a recusa em contratar empregados que integrem as chamadas listas negras mantidas por empresas e outras entidades, pelos mais variados motivos: por terem ajuizado reclamação trabalhista, por terem sido dirigentes sindicais ou qualquer outra espécie de representantes dos trabalhadores, etc ${ }^{316}$.

Uma forma interessante de se analisar se determinado candidato foi ou não discriminado no processo de seleção, desenvolvida por Eduardo Caamaño Rojo, seria verificando se o empregador respeitou os três limites do poder empregatício no momento do recrutamento. O primeiro destes limites ao poder empresarial seria a vedação da utilização de parâmetros que não guardem relação com a capacidade ou idoneidade pessoal como critério de seleção, salvo quando se tratar de uma atividade em que determinada característica seja fundamental para a realização dos afazeres, como, por exemplo, a abertura de vagas exclusivamente para mulheres para o desempenho da função de modelo de roupa feminina. O segundo limite consiste na vedação da utilização de critérios ou requisitos de seleção diferentes em base a uma condição de diferenciação proibida reprovável, que não guardem relação com a capacidade ou idoneidade pessoal para este posto de trabalho. Com base neste limite da liberdade de contratação do empresário, se impede, por exemplo, que se estabeleçam para um mesmo emprego requisitos de seleção distintos para homens e mulheres. $\mathrm{O}$

\footnotetext{
${ }^{315}$ Ibidem, p. 39.

${ }^{316}$ BRITO FILHO, José Cláudio Monteiro de. Op. cit., p. 46.
} 
terceiro e último limite ao poder empresarial corresponde à circunstância de que o empresário não pode utilizar, em geral, procedimentos de seleção que excluam a um número maior de pessoas (por exemplo mulheres ou homens, pessoas de um credo determinado, etc.), salvo quando eles se justificarem racionalmente pelos juízos de necessidade ou idoneidade, de acordo com o querido pela empresa. Há que se ter cuidado, portanto, com as exigências aparentemente neutras, que mesmo aplicadas a todos os candidatos, poderiam conduzir, em seus feitos, à eliminação de certos grupos de pessoas do processo de seleção, como, por exemplo, as mulheres ou os estrangeiros, dando lugar a um caso de discriminação indireta ${ }^{317}$.

Feitas estas considerações pode-se afirmar que se estará diante de uma discriminação na fase pré-contratual quando o empregador recrutar alguém utilizando como critério de seleção algum parâmetro que não guarde relação com a capacidade ou idoneidade pessoa; utilizar requisitos de seleção diferentes em base a uma condição de diferenciação proibida reprovável ou utilizar, em geral, procedimentos de seleção que excluam a um número maior de pessoas, salvo que se justifiquem racionalmente pelos juízos de necessidade ou idoneidade, de acordo com o desejado pela empresa.

${ }^{317}$ a) El primer límite al poder empresarial supone que el empleador no puede utilizar como criterio de selección algún parámetro que no diga relación com la capacidade o idoneidad personal, como es el caso, por ejemplo, del sexo o la nacionalidad, salvo que se trate de una actividad en que el sexo o algún otro criterio de diferenciación, en principio prohibido, sea exigencia para la realización del puesto, siendo, en todo caso, necesarias claridad y transparencia en relación con las actividades profesionales en las que ello se admite. Esta situación se presentaría, por ejemplo, para un puesto e modelo de ropa feminina ya que la naturaleza de la actividad a ser realizada presupone y justifica que la selección de los aspirantes a ese trabajo se circunscriba únicamente a mujeres.

b) El segundo límite conlleva que el empresario no puede utilizar criterios o requisitos de selección diferentes en base a una condición de diferenciación prohibida y reprochable, que no digan relación con la capacidad o idoneidad personal para ee puesto de trabajo. Por lo tanto, en base a este límite de la libertad de contratación del empresario, se excluye, por ejemplo, que se establezcan para un mismo empleo requisitos de selección distintos para hombre y mujeres.

c) por último, el tercer límite al poder empresarial corresponde a la circunstancia e que el empresario no puede utilizar, en general, procedimientos de selección que excluyan a un número mayor de personas (v.g. mujeres u hombres, personas de un credo determinado, etc.), salvo que se justifiquem racionalmente bajo los juicios de necesidad o idoneidad, de acuerdo a lo querido por la empresa. De esta manera, pueden existir exigencias aparentemente neutras, que aun siendo aplicadas a todos los candidatos, podrían conducir, en los hechos, a la eliminación de ciertos grupos de personas del proceso de selección, como por ejemplo las mujeres o los extranjeros, dando lugar a un caso de discriminación indirecta. (ROJO, Eduardo Caamaño. Op. cit., p. 108). 


\subsubsection{DISCRIMINAÇÃO NA FASE CONTRATUAL}

$\mathrm{Na}$ fase de manutenção do contrato, as formas mais comuns de discriminação são as preterições em promoções, bonificações, equiparação salarial, distinção de oportunidades, limitação de atuação, ou mesmo o trato pessoal menos cortês ou mais humilhante ou vexatório. Uma das características dos atos discriminatórios ocorridos neste inter é que apesar da discriminação ocorrer durante a vigência do liame empregatício, a vitima só busca reparação individual após a sua desconstituição, o que no direito brasileiro se explica na medida em que o fim da estabilidade decenal fez com que as ações trabalhistas, mesmo as relacionadas a fatos ocorridos durante o contrato de trabalho, somente são ajuizadas após a rescisão contratual. Isto torna ainda mais relevante e fundamental o papel das autoridades administrativas e do Ministério Público.

Outro aspecto para o qual cumpre atentar é o fato de que, a depender da ação discriminatória praticada, pode-se ter uma responsabilização contratual ou extracontratual do empregador. Explica-se, estando diante de uma discriminação na fase pré-contratual à vítima será conferida a chance de pleitear exclusivamente uma indenização compensatória pelo dano que lhe fora causado. Já na fase contratual, a depender de qual seja a conduta do empregador poder-se-á ter uma responsabilização contratual, como no caso do pleito de recebimento de diferenças salariais por equiparação salarial a um empregado que desempenhava a mesma função, com a mesma produtividade e perfeição técnica, há menos de dois anos (artigo 461 da CLT); ou extracontratual, com fundamento legal na aplicação subsidiária do Código Civil, como no caso de discriminação caracterizada por ofensas rogadas ao empregado.

Esta distinção, contudo, apresenta hoje efeitos meramente didáticos conquanto a Emenda Constitucional 45 tenha sepultado qualquer discussão porventura ainda remanescente quanto à competência da Justiça do Trabalho para apreciar as ações em que se busca reparação civil por dano moral decorrente da relação de emprego. 
Se de um lado, o empregador (ou ex-empregador) tem o direito e a faculdade de admitir aquele que mais the pareça adequado ao trabalho, bem ainda o de prestar informações sobre quem laborou para si, não pode, de outro lado, em nome dessa faculdade, utilizar-se da prerrogativa para praticar atos discriminatórios ${ }^{318}$.

\subsubsection{DISCRIMINAÇÃO POR OCASIÃO DA RESCISÃO DO CONTRATO DE TRABALHO}

Uma observação no mínimo curiosa a ser feita é que um ato discriminatório, no direito brasileiro atualmente concebido, tanto pode dar ensejo à cessação do contrato de trabalho, quanto justificar o seu restabelecimento. Explica-se. O empregado que for vítima de discriminação tem, entre outras prerrogativas a de rescindir indiretamente o seu contrato de trabalho, a depender das peculiaridades do caso, nos termos do artigo 483, "b", "d", "e" ou "g" da CLT. E aquele empregador que for vítima de uma dispensa arbitrária poderá postular judicialmente a sua readmissão nos termos do artigo $4^{\circ}$, I da Lei 9.029/95, se não preferir a percepção, em dobro, da remuneração do período de afastamento, corrigida monetariamente e acrescida dos juros legais.

6.4.4. COMBATE À DISCRIMINAÇÃO NO DIREITO INTERNACIONAL DO TRABALHO

Como salienta José Cláudio Monteiro de Brito Filho, tem-se, no plano internacional, todo um arsenal legislativo contra a discriminação, quer

${ }^{318}$ LIMA, Francisco Gérson Marques de. Op. cit., p. 31. 
no plano geral, quer no plano de determinados motivos ou hipóteses geradoras do preconceito $^{319}$. Inicialmente, tinha-se apenas o art. 427 do Tratado de Versalhes, em que se agasalhava o princípio de "salário igual, sem distinção de sexo, para trabalho igual em quantidade e qualidade", princípio, aliás, que passou a integrar o preâmbulo da Constituição da OIT quando esta foi reformada, em $1946^{320}$. Somente com a Declaração Universal dos Direitos do Homem, de 1948, o tema voltou a ser objeto de normatização no plano internacional. Nesta restou estatuído, logo no artigo 2.1. que toda pessoa tem todos os direitos e liberdades nela proclamados "sem distinção alguma de raça, cor, sexo, idioma, religião, opinião política ou de qualquer índole, origem nacional ou social, posição econômica, nascimento ou qualquer outra condição", e no artigo 23, n. 2 que "Toda pessoa tem direito, sem nenhuma discriminação, a um salário igual para um trabalho igual".

Segundo Vera Lúcia Carlos, a Declaração Universal dos Direitos do Homem constitui a norma fundamental da qual emanam as regras e dispositivos que visam impedir a discriminação e que possibilitam a toda pessoa gozar de seus direitos, sem distinção de raça, cor, sexo, língua, religião, opinião política, origem nacional ou social, riqueza, nascimento ou qualquer outra condição (art. II), assim como os deveres para garantir igual proteção contra qualquer tipo de discriminação que viole seus textos e contra qualquer incitamento a tal discriminação ${ }^{321}$.

O primeiro instrumento internacional emanado da OIT a se pronunciar sobre o tema da discriminação foi a Convenção no. 100, de 1951, que, na mesma diretriz da Recomendação 30, de 1928, da Organização das Nações Unidas, se limitou, contudo, a tratar da igualdade de homens e mulheres em relação à remuneração, entendida esta como o salário, o soldo ordinário, básico ou mínimo, e qualquer outro emolumento em dinheiro ou em espécie pagos pelo empregador, direta ou indiretamente, ao trabalhador, em decorrência do emprego deste último, tanto no setor público quanto no setor privado. Como salienta Vera Lúcia Carlos, a Convenção em questão foi ratificada por grande número de países que, em decorrência do

\footnotetext{
${ }^{319}$ BRITO FILHO, José Cláudio Monteiro de. Op. cit., p.62.

${ }^{320}$ MAGANO, Octávio Bueno e MALLET, Estêvão. Op. cit., p. 164.

${ }^{321}$ CARLOS, Vera Lúcia. Op. cit., pp. 44/45.
} 
compromisso firmado, passaram a editar leis que estabeleciam o direito à igualdade de remuneração. Entre os exemplos de reformas legislativas decorrentes desta Convenção referidas por ela estão as modificações introduzidas no Código do Trabalho francês, em 1981 e 183, e as alterações efetuadas no Código de Madagascar, em $1975^{322}$.

A Convenção em questão, complementada pela Recomendação 90, de 1951, foi ratificada pelo Brasil em abril de 1957 e promulgada pelo Decreto 41.721, de junho de 1957. Ressalte-se, contudo, que a OIT, reconhecendo que não se podia conseguir a igualdade de remuneração sem a eliminação da discriminação em todas as áreas do emprego, adotou, anos depois, uma Convenção mais ampla.

Ainda em 1957, o tratado de Roma, que instituiu a Comunidade Econômica Européia, assegurou, em seu art. 119, a igualdade de retribuição para um mesmo trabalho, o que, segundo Vera Lúcia Carlos, acabou influenciando a legislação interna de vários países, como Reino Unido, Canadá e Estados Unidos ${ }^{323}$.

No ano seguinte se editou a Convenção n. 111 da OIT. Segundo o eminente professor Eduardo Caamaño Rojo, esta convenção realça, em um contexto propriamente laboral, a incidência que tem o tema da proibição da discriminação no emprego, considerando que a Declaração de Filadélfia afirma que todos os seres humanos, sem distinção de raça, credo ou sexo, têm direito a perseguir seu bem-estar material e seu desenvolvimento espiritual em condições de liberdade e dignidade, de segurança econômica e em igualdade de oportunidades, e caracteriza a

\footnotetext{
322 Ibidem, p. 45. No artigo $2^{\circ}$ da Convenção n. 100 da OIT restou estatuído que: "cada membro deverá, por meios adaptados aos métodos em vigor para a fixação das taxas de remuneração, incentivar e, na medida em que tudo isto é incompatível com os ditos métodos, assegurar a aplicação a todos os trabalhadores do princípio de igualdade de remuneração para a mão-de-obra masculina e a mão-de-obra feminina por um trabalho de igual valor.Este princípio poderá ser aplicado por meio: a) seja da legislação nacional; b) seja de qualquer sistema de fixação de remuneração estabelecido ou reconhecido pela legislação; c) seja de convenções coletivas firmadas entre empregadores e empregados; d) seja de uma combinação de diversos eventos" ( In: SÜSSEKIND, Arnaldo. Direito Internacional do Trabalho. São Paulo: LTr, 1983, p. 420).

${ }^{323}$ CARLOS, Vera Lúcia. Op. cit., p. 45.
} 
discriminação como uma violação dos direitos enunciados pela Declaração Universal dos Direitos Humanos ${ }^{324}$.

Esta Convenção específica o que deve ser considerado discriminação no desenvolvimento de um trabalho subordinado, asseverando em seu artigo $1^{\mathrm{o}}$ inciso 1 que:

1. Para os fins da presente Convenção o termo "discriminação" compreende:

a) Toda distinção, exclusão ou preferência fundada na raça, cor, sexo, religião, opinião política, ascendência nacional ou origem social, que tenha por efeito destruir ou alterar a igualdade de oportunidades ou de tratamento em matéria de emprego ou profissão:

b) Qualquer outra distinção, exclusão ou preferência que tenha por efeito destruir ou alterar a igualdade de oportunidade ou de tratamento em matéria de emprego ou profissão que poderá ser especificada pelo Membro interessado depois de consultadas as organizações representativas de empregadores e trabalhadores, quando estas existam, e outros organismos adequados ${ }^{325}$.

Analisando-se o referido conceito, percebe-se, com clareza solar, que nem todo tratamento diferenciado é considerado discriminatório pela Organização Internacional do Trabalho. É preciso que uma conduta tenha por conseqüência anular o alterar a igualdade de tratamento ou de oportunidades para ser considerada discriminatória. Por outro lado, a Convenção optou por não apresentar um rol de situações em que é possível verificar a conduta discriminatória, optando por deixar em aberto quais poderiam ser estas. Ademais, não se trata apenas de evitar a discriminação para garantir a todas as pessoas a possibilidade de obter emprego, mas também evitar as dificuldades que possam afetar aos trabalhadores para obter um

\footnotetext{
${ }^{324}$ En un contexto propriamente laboral, este convenio realza la incidencia que tiene el tema de la prohibición de discriminación en el empleo, considerando que la Declaración de Filadelfia afirma que todos los seres humanos, sin distinción de raza, credo ou sexo, tienem derecho a perseguir su bienestar maerial y su desarollo espiritual en condiciones de libertad y dignidade, de seguridad económica en igualdade de oportunidades, como asimismo, que la discriminación constituye una violación de los derechos enunciados por la Declaración Universal de los Derechos Humanos. (ROJO, Eduardo Caamaño. Op. cit., p. 59). No mesmo sentido Vera Lúcia Carlos observa "Segundo a doutrina, essa Convenção inspirou-se nos princípios contidos na Declaraçao de Filadélfia, que na parte II, letra "a", assim dispõe:" "todos os seres humanos, sem distinção de raça, credo ou sexo, têm direito a perseguir seu bem-estar material e seu desenvolvimento espiritual em condições de liberdade e dignidade, de segurança econômica e em igualdade de oportunidades”. (CARLOS, Vera Lúcia. Op. cit., p. 45).
}

${ }^{325}$ SÜSSEKIND, Arnaldo. Op. cit., p. 443. 
emprego melhor ou ascender a outro de hierarquia superior. A Convenção adota, portanto, como critério as conseqüências objetivas das medidas discriminatórias, situação que permite afirmar que as discriminações indiretas e fenômenos como a segregação profissional estão dentro do âmbito de aplicação do convênio ${ }^{326}$.

Eduardo Caamaño Rojo destaca que o artigo 1, inciso 1 assinala que os termos emprego e ocupação incluem tanto o acesso aos meios de formação profissional e a admissão no emprego e as diversas ocupações, como as condições de trabalho. Para ele, com base no referido preceito a formação e a promoção, a retribuição, o estabelecimento, a fixação da jornada, os sistemas de classificação profissional, o período de prova do contrato de trabalho, os sistemas de participação na empresa, etc, são assuntos de interesse públicos, sujeitos, portanto, ao princípio da igualdade ${ }^{327}$.

No que se refere à obrigação imposta aos Estados, o artigo $2^{\circ}$ da Convenção estabelece que:

Qualquer membro para o qual a presente convenção se encontre em vigor compromete-se a formular e aplicar uma política nacional que tenha por fim promover, por métodos adequados às circunstâncias e aos usos nacionais, a igualdade de oportunidades e de tratamento em matéria de emprego e profissão, com o objetivo de eliminar toda discriminação nessa matéria ${ }^{328}$.

\footnotetext{
${ }^{326}$ Neste sentido são as lições de Eduardo Caamaño Rojo: “Asimismo, es destacable que no se trata tan sólo de evitar la discriminación a fin de garantizar a todas las personas la posibilidad de obtener um empleo, sino también evitar las dificultades que pudieram afectar a los trabajadores para obtener um empleo mejor o ascender a otro de jerarquía superior. Se adopta, por lo tanto, como criterio las consecuencias objetivas de las medidas antidiscriminatorias, situación que permite afirmar que las discriminaciones indirectas y fenómenos tales como la segregación profesional están dentro el ámbito de aplicación del convenio" (ROJO, Eduardo Caamaño. Op. cit., pp. 60/61).

${ }^{327}$ Es también relevante hacer presente que, para los efectos del convenio, el artículo 1 inciso 3 señala que los términos empleo y ocupación incluyen tanto el acceso a los medios de formación profesional y la admisión en ele empleo y en las diversas ocupaciones, como también, las condiciones de trabajo. Es decir, que la formación y la promoción, la retibuición, el establecimiento y fijación de la jornada, los sistemas de clasificación profesional, el período de prueba del contrato de trabajo, los sistemas de participación en la empresa, etc., son asuntos de interés público las condiciones de trabajo, conforme a los términos "empleo y ocupación" y a todas ellas les es aplicable el principio de igualdad. (ROJO, Eduardo Caamaño. Op. cit., p. 61).

${ }^{328}$ SÜSSEKIND, Arnaldo. Op. cit., p. 444.
} 
Interpretando o referido dispositivo, Eduardo Caamaño Rojo pondera que nele se reconhece que o direito à igualdade de tratamento e de oportunidades não pode ser considerado um direito absoluto e se contempla certo grau de flexibilidade na aplicação do princípio da igualdade de tratamento ${ }^{329}$, o que seria ainda reforçado no artigo $5^{\circ}$, incisos 1 e 2 que assim dispõe:

1. As medidas especiais de proteção ou de assistência previstas em outras convenções ou recomendações adotadas pela Conferência Internacional do Trabalho não são consideradas discriminação.

2. Qualquer Membro pode, depois de consultadas as organizações representativas de empregadores e trabalhadores quando estas existam, definir como não discriminatórias quaisquer outras medidas especiais que tenham por fim salvaguardar as necessidades particulares de pessoas em relação às quais a atribuição de uma proteção ou assistência especial seja, de uma maneira geral, reconhecida como necessária, por motivos tais como o sexo, a invalidez, os encargos de família ou o nível social ou cultural ${ }^{330}$.

Vera Lúcia Carlos, por sua vez, destaca que a Convenção 111 da OIT prevê no art. 3º, letra "b", que, para a implantação de medidas concretas de enfrentamento da discriminação racial, mostra-se imprescindível à elaboração de programas educativos, “cujo objetivo deverá ser o de favorecer, preparar, conscientizar, persuadir as pessoas da relevância e importância das medidas no intuito de eliminar toda discriminação, ${ }^{\text {331. }}$.

A Convenção 111 da OIT restou complementada pela Recomendação 111, de 1960, da Organização Internacional do Trabalho, aprovada na $42^{\mathrm{a}}$ reunião da Conferência Internacional do Trabalho (Genebra, 1958) e que entrou em vigor no plano internacional, em 15 de junho de 1960. Foi aprovada no Brasil pelo Decreto Legislativo 104, de 24 de novembro de 1964, e promulgada pelo Decreto 62.150 , de 19 de janeiro de 1968, com vigência nacional a partir de 26 de novembro de $1966^{332}$.

\footnotetext{
${ }^{329}$ En relación con lo anterior, se reconoce en este instrumento internacional que el derecho a la igualdad de trato y de oportunidades no puede considerarse un derecho absoluto y se contempla cierto grado de flexibilidad en la aplicación del principio de igualdade de trato (ROJO, Eduardo Caamaño. Op. cit., p. 62).

${ }^{330}$ SÜSSEKIND, Arnaldo. Op. cit., p. 444.

331 CARLOS, Vera Lúcia. Op. cit., p. 47.

${ }^{332}$ Ibidem, pp. 46/47.
} 
As Convenções 100 e 111 da OIT ajudaram a tornar o combate à discriminação práticas quase universais, na medida em que nove de cada dez Estados Membros as ratificaram. Não fosse isto o bastante, a ratificação da Convenção 111 pela China em 2006 aumentou consideravelmente o número de pessoas cobertas pelo referido instrumento no mundo inteiro ${ }^{333}$.

Outra norma internacional que merece ser destacada é a Convenção das Nações Unidas sobre a eliminação de todas as formas de Discriminação contra a Mulher adotada em dezembro de 1979, e em vigor a partir de abril de 1982, em cujo artigo 12 a discriminação contra as mulheres restou definida da seguinte forma:

Toda a distinção, exclusão ou restrição fundada no sexo ou que tenha por objetivo ou resultado prejudicar ou anular o reconhecimento, gozo, ou exercício dos direitos humanos e das liberdades fundamentais pela mulher, qualquer que seja seu estado civil, nos mais diversos campos.

\section{A referida Convenção condena a prática de}

discriminação por parte de qualquer pessoa, organização ou empresa, em todas as suas formas e os seus domínios, principalmente na vida política e pública, assegurando aos homens e às mulheres os mesmos direitos, particularmente às trabalhadoras rurais, e determina ainda que os Estados-membros tomem medidas adequadas para proibir a dispensa de empregadas em decorrência do estado civil, de gravidez ou maternidade, e ainda que concedam proteção especial às mulheres durante à gravidez. Mas não foi só.

\footnotetext{
${ }^{333}$ La condena de la discriminación en el empleo y la ocupación es hoy día casi universal, al igual que el compromiso político de afrontarla. Nueve de cada diez Estados Miembros de la OIT han ratificado el Convenio sobre igualdad de remuneración, 1951 (núm. 100), y el Convenio sobre la discriminación (empleo y ocupación), 1958 (núm. 111), que son las dos normas internacionales del trabajo fundamentales dedicadas a este tema (véase la parte I, capítulo 1). Al ratificar China el Convenio núm. 111 en 2006, ha aumentado considerablemente el número de personas cubiertas por dicho instrumento en el mundo entero. También se ha registrado un progreso notable en muchos países, tanto en el frente jurídico como en el institucional (ORGANIZAÇÃO INTERNACIONAL DO TRABALHO (OIT). La igualdad...op. cit., p. 19). No mesmo trabalho a Organização Internacional do Trabalho esclarece que, por ocasião da $96^{\mathrm{a}}$ Reunião Anual, os 16 países que ainda não haviam ratificado a Convenção n. 100 eram "Bahrein, Estados Unidos, Islas Salomón, Kiribati, Kuwait, República Democrática Popular Lao, Liberia, Montenegro, Myanmar, Namibia, Omán, Qatar, Samoa, Somalia, Suriname y Timor-Leste”, e os 14 que ainda não haviam ratificado a Convenção n. 111 eram "Estados Unidos, Islas Salomón, Japón, Kiribati, República Democrática Popular Lao, Malasia, Montenegro, Myanmar, Omán, Samoa, Singapur, Suriname, Tailandia y Timor-Leste" (ibidem, p. 26)
} 
A Convenção em questão ainda estabeleceu que nem as medidas adotadas pelos Estados-membros objetivando tutelar a maternidade, nem as de caráter transitório adotadas com o fim de alcançar mais rapidamente a igualdade de fato entre homens $\mathrm{e}$ mulheres, não devem ser consideradas discriminatórias ${ }^{334}$.

Vera Lúcia Carlos destaca a forte influência da referida Convenção na legislação brasileira, em especial na Constituição vigente e na elaboração da Lei 7.855/89, que derrogou os dispositivos celetistas que proibiram o trabalho noturno das mulheres na indústria, em subterrâneos, nas minerações de subsolo, o trabalho realizado em condições insalubres e perigosas, o trabalho nas pedreiras e nas obras de construção públicas ou particulares ${ }^{335}$.

Também é digno de especial referência o Pacto Internacional de Direitos Econômicos, Sociais e Culturais, de 1966, em cujo art. $7^{\circ}$ reconhece-se o direito de todos os trabalhadores a um salário eqüitativo e igual por trabalho de igual valor, sem distinção de nenhuma espécie, sublinhando-se a necessidade de se assegurar a aludida igualdade no que respeita ao trabalho da mulher em comparação ao do homem. Cumpre ainda aludir a Convenção Americana sobre Direitos Humanos que, em seu artigo $24^{\mathrm{a}}$, prevê a igualdade de direitos, sem discriminação ${ }^{336}$.

Complementando as Convenções 100 e 110, que não fazem referência aos trabalhadores com responsabilidade familiares, a OIT elaborou a Convenção n. 156. O seu escopo foi justamente suprir esta lacuna apregoando a adoção de medidas especiais que tornem possível evitar que os problemas com que se enfrentam todos os trabalhadores seja agravados em relação àqueles que tem responsabilidades familiares.

Eduardo Caamaño Rojo destaca que a convenção coloca em igualdade de condições em respeito à aplicação das medidas especiais que contempla, tanto os homens quanto as mulheres que tenham a qualidade de

\footnotetext{
${ }^{334}$ CARLOS, Vera Lúcia. Op. cit., p. 46.

${ }^{335}$ CARLOS, Vera Lúcia. Op. cit., p. 46.

${ }^{336}$ MAGANO, Octávio Bueno e MALLET, Estêvão. Op. cit., p. 164.
} 
trabalhadores, não havendo nenhum favorecimento em relação a estas. Em seguida aplaude a iniciativa, destacando ser uma inovação importante que a extensão da responsabilidade familiar não se limite somente aos filhos, mas compreenda também, com bastante realismo, outros familiares diretos que possam requerer cuidado ou assistência, o que abrange um número significativo de pessoas nos países em desenvolvimento, onde há escassez de instâncias ou estabelecimentos que dêem assistência a pessoas em idade senil ou inválidas ou que requeiram algum tipo especial de atenção. Por fim, o autor chileno ressalta ainda que a Convenção destaca a necessidade de proteção desses trabalhadores como decorrência da circunstância de que a assunção de uma responsabilidade familiar limita suas possibilidades de se preparar para a atividade econômica, bem como de ingressar, participar ou progredir nela, o que as coloca em uma situação desvantajosa que justifica que lhes se sejam outorgadas uma proteção especial que obste as práticas discriminatórias ou medidas discriminatórias no emprego $^{337}$.

No tocante à atuação estatal no combate a esta discriminação, o artigo $3^{\circ}$ da Convenção em questão destaca que cada Estado Membro deverá incluir entre os objetivos principais de sua política nacional o de permitir que as pessoas com responsabilidades familiares que desempenhem ou desejem desempenhar um emprego exerçam seu direito de fazê-lo sem ser objeto de discriminação e, na medida do possível, sem conflito entre suas responsabilidades familiares e profissionais $^{338}$. Visando o cumprimento do seu objetivo central, a Convenção ora

${ }^{337}$ De la definición anterior, cabe subtrayar, en primero lugar, que el convenio coloca en igualdad de condiciones respecto de la aplicación de las medidas especiales que contempla, tanto a hombres como a mujeres que tengam la calidad de trabajadores. Em segundo lugar, constituye una innovación importante en nuestra opinión, que la extensión de la responsabilidad familiar no se limita sólo a los hijos, sino que comprende también, con bastante realismo, a otros familiares directos que no puedan requerir cuidado o asistencia, lo que suele involucrar a un número significativo de personas en los países en desarollo, en los que la escasez de instancias o establecimientos que den asistencia a personas en edad senil, o inválidas, o que requieran de algún tipo especial de atención, origina que sus familiares directos, sobre todo mujeres, deban asumir su cuidado. En tercer lugar, corresponde destacar que la necesidad de protección de estos trabajadores, según el Convenio n. 156 de la OIT viene dada por la circunstancia de que la asunción de una responsabilidad familiar limita sus posibilidades de prepararse para la actividad económica, como asimismo, de ingresar, participar y progresar en ella, lo que coloca estas personas en una situación desventajosa que amerita que se les otorgue una protección especial que les garantice que no sean objeto de práticas o medidas discriminatórias en el empleo. (ROJO, Eduardo Caamaño. Op. cit., p. 61).

338 Artículo 3

1. Con miras a crear la igualdad efectiva de oportunidades y de trato entre trabajadores y trabajadoras, cada Miembro deberá incluir entre los objetivos de su política nacional el de permitir que las personas con responsabilidades familiares que desempeñen o deseen desempeñar un empleo ejerzan su derecho a 
estudada trouxe ainda, nos seus artigos 4 e 5, a determinação de que os Estados deverão adotar todas as medidas compatíveis com as condições e possibilidades nacionais para permitir aos trabalhadores com responsabilidades familiares o exercício de seu direito a eleger livremente seu emprego; ter em conta suas necessidades no que concerne às codificações do emprego e a seguridade social; ter em conta as necessidades dos trabalhadores com responsabilidades familiares na planificação das comunidades locais ou regionais e desenvolver ou promover serviços comunitários, públicos ou privados, tais como os serviços e meios de assistência à infância e de assistência familiar ${ }^{339}$. Por fim, urge salientar ainda que o artigo $8^{\circ}$ desta Convenção estatui não dever a responsabilidade familiar constituir, por si só, uma causa justificada para se pôr fim a uma relação de emprego.

A Organização Internacional do Trabalho reconheceu em seu Manual de capacitação e informação sobre gênero, raça, pobreza, e emprego que a plena igualdade de oportunidades entre homens e mulheres, negros e brancos não pode ser alcançada apenas pela legislação, conquanto esta tenha um papel fundamental $^{340}$. Possivelmente por esta razão, a Organização Internacional do Trabalho vem desenvolvendo mundialmente, com o fito de combater a discriminação no emprego, um programa intitulado GPE (Programa de Fortalecimento Institucional para a Igualdade de Gênero, Erradicação da Pobreza e Geração de Emprego), que visa capacitar gestores e gestoras responsáveis por políticas de geração de empregos

hacerlo sin ser objeto de discriminación y, en la medida de lo posible sin conflicto, entre sus responsabilidades familiares y profesionales.

2. A los fines del párrafo 1 anterior, el término discriminación significa la discriminación en materia de empleo y ocupación tal como se define en los artículos 1 y 5 del Convenio sobre la discriminación (empleo y ocupación), 1958. Disponível em <http://www.ilo.org/ilolex/spanish/convdisp1.htm>, acesso em 13 de janeiro de 2008.

339 Artículo 4

Con miras a crear la igualdad efectiva de oportunidades y de trato entre trabajadores y trabajadoras, deberán adoptarse todas las medidas compatibles con las condiciones y posibilidades nacionales para:

a) permitir a los trabajadores con responsabilidades familiares el ejercicio de su derecho a elegir libremente su empleo;

b) tener en cuenta sus necesidades en lo que concierne a las condiciones de empleo y a la seguridad social.

Artículo 5

Deberán adoptarse además todas las medidas compatibles con las condiciones y posibilidades nacionales para:

a) tener en cuenta las necesidades de los trabajadores con responsabilidades familiares en la planificación de las comunidades locales o regionales;

b) desarrollar o promover servicios comunitarios, públicos o privados, tales como los servicios y medios de asistencia a la infancia y de asistencia familiar. Disponível em $<$ http://www.ilo.org/ilolex/spanish/convdisp1.htm>. Acesso em 12 de janeiro de 2007. ) 
Ademais, a OIT exerce, no plano internacional, funções de organismo de controle, na medida em que o artigo 22 de sua Constituição obriga os Estados-membros a apresentar uma memória a cada quatro anos sobre as medidas adotadas para efetivar a implementação das Convenções ratificadas. Algumas convenções, como, por exemplo, as de número 100 e 111, exigem que essa memória seja apresentada a cada dois anos. No tocante às convenções não-ratificadas, a Constituição da OIT habilita o Conselho de Administração a solicitar relatórios sobre a aplicação de suas determinações e as razões de sua não-ratificação. No nível nacional, o papel de controle corresponde à Inspeção do Trabalho, a quem cabe vigiar o cumprimento das normas e informar e assessorar empregadores e trabalhadores nessa matéria aplicando sanções administrativas por infrações às normas trabalhistas que consistem, geralmente, em multas de montante variável ${ }^{341}$.

\subsubsection{COMBATE À DISCRIMINAÇÃO NO DIREITO ESTRANGEIRO}

Analisando-se as inovações surgidas nos ordenamentos jurídicos espalhados ao longo do globo, percebe-se que o tema do combate à discriminação vem recebendo significativa atenção nos seus mais distantes rincões, sobretudo no que diz respeito à - igualdade de oportunidade e tratamento no emprego (inclusive igualdade entre homens e mulheres; ao direito de sindicalização; ao acesso à justiça; à não discriminação no emprego; à saúde e segurança no trabalho; à proteção contra assédio sexual e constrangimento moral; ao acesso à informações e proteção da intimidade; à liberdade de manifestação do pensamento; à proibição do trabalho forçado ${ }^{342}$.

\footnotetext{
${ }^{340}$ ORGANIZAÇÃO INTERNACIONAL DO TRABALHO OIT. Manual...op. cit.,, v.1. p. 108.

${ }^{341}$ ORGANIZAÇÃO INTERNACIONAL DO TRABALHO (OIT). Ibidem, p. 108.

${ }^{342}$ ROMITA, Arion Sayão. Op cit, p. 30. O mesmo autor demonstra suas assertivas relacionando as seguintes normas: Lei n. 9, de 3.7.2000, de Santa Lúcia, sobre igualdade de oportunidades e tratamento no emprego; Notificação de 7.14.2000, do Japão sobre políticas básicas de igualdade de oportunidades entre homens e mulheres no emprego; Lei n.773, de 26.10.2000, da Suécia, que altera a Lei n. 433, de 1991, sobre igualdade de oportunidades; Notificação n. 909, de 27.9.2000, da Dinamarca, sobre a lei que dispõe acerca da equiparação salarial entre homens e mulheres; Lei n. 71, de 26.1.2001, da Finlândia,
} 
No Chile, segundo Eduardo Caamaño Rojo ${ }^{343}$, são três as normas constitucionais que fixam o marco partir do qual se estrutura o reconhecimento do direito a igualdade de tratamento e de não discriminação. Em primeiro lugar, haveria o artigo $1^{\circ}$ da Constituição que estabelece que "as pessoas nascem livres e iguais em dignidades e direitos" e, em seu inciso final, estabelece ser dever do Estado "promover a integração harmônica de todos os setores da Nação e assegurar o direito das pessoas a participar com igualdade de oportunidades na vida nacional”. O segundo seria o artigo 19, n. 2 da Constituição, que, inserido dentro do

que altera a Lei n. 609, de 1986, sobre igualdade de salários e condições de trabalho entre homens e mulheres; Lei n. 144 de 3.11.2000, de Chipre, que altera a Lei n. 158, de 1989, sobre equiparação salarial para o trabalho de igual valor entre homens e mulheres; Lei n. 397, de 9.5.2001, da França, sobre igualdade profissional entre mulheres e homens; Lei n. 69, de 20.10.2000, de Trinidad e Tobago, sobre igualdade de oportunidades no emprego; Lei n. 8.107, de 18.7.2001, da Costa Rica, que determina a incorporação de um novo título $\left(\mathrm{o} 11^{\circ}\right)$ ao Código do Trabalho, referente à proibição de discriminação no trabalho em razão da etnia, idade, gênero ou religião; Decreto n. 1035, de 8.11.2001, da França que institui um contrato para igualdade profissional entre mulheres e homens; Lei n. 445, de 7.6.2001, da Dinamarca, que altera a lei sobre equiparação salarial entre mulheres homens; Lei n. 47, de 27.6.2001, da Austrália (Vitória), sobre tolerância racial e religiosa; Lei de 21.6.2002, da Eslovênia, sobre igualdade de oportunidades entre homens e mulheres; Notificação, n. 553, de 2.7.2002, da Dinamarca, sobre a Lei n. 157, de 1985, que dispõe sobre igualdade de oportunidades entre homens e mulheres; Lei de 21.12.2002, de Maurício, que proíbe discriminação por motivo de sexo; Lei n. 205, de 6.12.2002, de Chipre, que dispõe sobre igualdade de tratamento entre homens e mulheres no emprego; Lei n. 177, de 27.9.2002, de Chipre, que dispõe sobre equiparação salarial entre homens e mulheres para trabalho de igual valor; Lei n. 307, de 5.6.2003, da Suécia que proíbe a discriminação. Lei n. 762, de 26.10.2000, da Suécia, que altera a Lei n. 130, de 1999, introduzindo medida contra discriminação étnica no emprego; Lei n. 207, de 26.5.2000, do Líbano, que altera disposições do Código do Trabalho, de 26.9.1946, sobre proibição de discriminação no emprego entre homens e mulheres; Lei n. 19.739, de 26.7.2001, do Chile, que altera o Código do Trabalho para proibir a discriminação por idade e estado civil na postulação de empregos; Lei n. 109, de 25.10.2000, da Áustria, que altera a lei sobre trainees, para proibir discriminação por motivo de sexo; Lei n. 52, de 129.2000, da Áustria (Vitória), sobre igualdade de oportunidades de 1995, para proibir discriminação com base em identidade de gênero ou orientação sexual; Lei n. 1.129, de 7.7.2000, da Moldávia, sobre sindicatos de trabalhadores, que proíbe discriminação com base na condição de sindicalizado; Lei n. 1.066, de 16.11.2001, da França, sobre luta contra as discriminações; Circular n. 31, de 26.3.2001 do Ministério do Trabalho da Itália, sobre atividades de controle em tema de proibição da discriminação e de igualdade de oportunidades; Lei de 16.2.2001 (LPartG), da Alemanha, sobre proibição de discriminação relativa a parcerias homossexuais; Lei n. 35, de 7.6.2001, da Austrália (Queesland), que altera a Lei Antidiscriminação, de 1991; Lei de 5.3.2002, da Bélgica, sobre o princípio de não-discriminação em favor dos trabalhadores a tempo parcial; Lei de 5.6.2002, da Bélgica, sobre o princípio de não discriminação em favor de trabalhador com contrato de trabalho de duração determinada; Lei n. 5, de 5.2.2002, de Moçambique sobre não discriminação nos locais de trabalho em favor de trabalhadores ou candidatos a emprego portadores de HIV/AIDS; Lei de 20.1.2003, da Bélgica, que altera a lei de 30.7.1981, reforçando a legislação contra o racismo e a xenofobia; Lei de 10.6.2003, do México, que dispõe sobre a proibição de todas as formas de discriminação; Decreto n. 43, de 4.7.2003, de Angola, que aprova o regulamento sobre HIV/AIDS, dispondo sobre a proteção de cidadãos soropositivos; Lei n. 310, de 5.6.2003, da Suécia, que altera a Lei n. 307, para proibir discriminação no emprego em razão de orientação sexual; Regulamento n. 1.660, de 26.6.2003, do Reino Unido, sobre igualdade no emprego, proibindo discriminação por motivo de religião ou crença; Regulamento n. 1.661, de 26.6.2003, do Reino Unido, sobre igualdade no emprego, proibindo discriminação por motivo de orientação sexual342. A seguir, se estudará as normas que suportam o combate a discriminação em alguns dos países acima referidos.

${ }^{343}$ ROJO, Eduardo Caamaño. Op. cit., pp. 68/69 
capítulo que trata dos direitos e deveres constitucionais, assegura a todas as pessoas igualdade perante a lei, exaltando que no Chile não há pessoa nem grupos privilegiados, não há escravos e aquele que pisar em seu solo tornar-se-á livre, além de instituir a igualdade entre homem e mulher e determinar que nem a lei nem qualquer autoridade poderão estabelecer diferenciações arbitrárias. Por fim, haveria, o artigo 19 n. 16 inciso $3^{\circ}$ que assegura a todas as pessoas a liberdade de trabalho e sua proteção, nos seguintes termos:

\begin{abstract}
A liberdade de trabalho e sua proteção.
Toda pessoa tem direito a livre contratação e a livre eleição do trabalho com uma justa remuneração.

Proíbe-se qualquer discriminação que não se baseie na capacidade ou idoneidade pessoal, sem prejuízo de que a lei possa exigir a nacionalidade chilena ou limites de idade para determinados $\operatorname{casos}^{344}$.
\end{abstract}

Em termos de legislação infraconstitucional, o combate

à discriminação nas relações de trabalho no referido país andino encontra suporte, sobretudo, no artigo $2^{\circ}$, incisos $3^{\circ}, 4^{\circ}$ e $5^{\circ}$, do Código do Trabalho que, após as modificações instituídas pelas Leis 19.759/01 e 19.812/02:

São contrários aos princípios das leis laborais os atos de discriminação.

Os atos de discriminação são as distinções, exclusões ou preferências baseadas em motivos de raça, cor, sexo, idade, estado civil, sindicalização, religião, opinião pública, nacionalidade, ascendência nacional ou origem social, que tenham por objeto anular ou alterar a igualdade de oportunidades ou de tratamento no emprego e a ocupação. Contudo, as distinções, exclusões ou preferências baseadas nas qualificações exigidas para um emprego determinado não serão consideradas discriminação ${ }^{345}$.

Também na Argentina o combate à discriminação

principia pela Constituição Nacional. Diversos são os dispositivos da lei maior que

${ }^{344}$ La libertad de trabajo y su protección. Toda persona tiene derecho a la libre contratación y a la libre elección del trabajo con una justa remuneración.Se prohibe cualquiera discriminación que no se base en la capacidad o idoneidad personal, sin perjuicio de que la ley pueda exigir la nacionalidad chilena o límites de edad para determinados casos. Disponível em: $<$ http://www.camara.cl/legis/constitucion/contitucion_politica.pdf $>$. Acesso em 15 de janeiro de 2008.

${ }^{345}$ Son contrarios a los principios de las leyes laborales los actos de discriminación. Los actos de discriminación son las distinciones, exclusiones o preferencias basadas en motivos de raza, color, sexo, edad, estado civil, sindicación, religión, opinión política, nacionalidad, ascendencia nacional u origen social, que tengan por objeto anular o alterar la igualdad de oportunidades o de trato en el empleo y la ocupación. Con todo, las distinciones, exclusiones o preferencias basadas en las calificaciones exigidas para un empleo determinado no serán consideradas discriminación. 
disciplinam o combate à discriminação. Em seu artigo 14, a Constituição assegura a igualdade de direitos não apenas entre todos os argentinos, mas entre todos os habitantes da Nação, o que assegura aos estrangeiros lá residentes a igual proteção em relação aos nacionais. Como, entretanto, a referida norma é de eficácia limitada, tendo o constituinte optado por esclarecer que essa igualdade se fará na forma das leis que regulamentem o seu exercício, nada impede que a legislação infraconstitucional estabeleça distinções ${ }^{346}$. O artigo 14 bis, por sua vez, estabelece que a legislação assegurará ao trabalhador condições dignas e eqüitativas de trabalho ${ }^{347}$. O artigo 16, por sua vez, consagra a igualdade formal e a igualdade de oportunidade de acesso aos empregos $^{348}$. Por fim, especial referência merece o artigo 75 do texto constitucional argentino, no qual se incluiu, dentre as atribuições do Congresso Nacional daquele país o dever de legislar e promover ações afirmativas que garantam igualdade real de oportunidades de tratamento e pleno gozo de exercício dos direitos reconhecidos pela Constituição e pelos tratados internacionais vigentes sobre direitos humanos ${ }^{349}$.

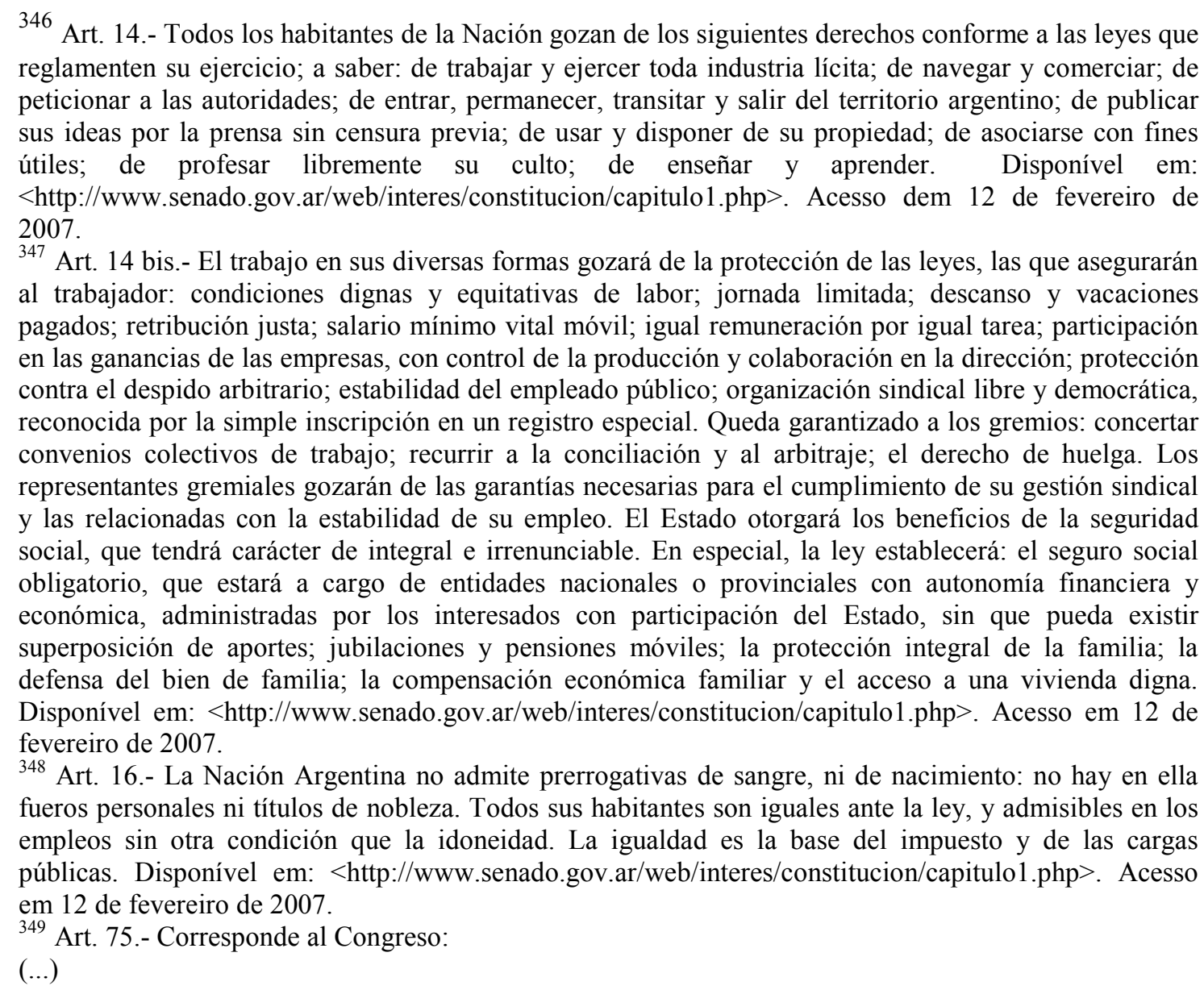
23. Legislar y promover medidas de acción positiva que garanticen la igualdad real de oportunidades y de trato, y el pleno goce y ejercicio de los derechos reconocidos por esta Constitución y por los tratados internacionales vigentes sobre derechos humanos, en particular respecto de los niños, las mujeres, los ancianos $\mathrm{y}$ las personas con discapacidad. 
Em termos de legislação infraconstitucional merece destaque, na Argentina, a Lei 23.592. Em seu artigo primeiro a referida norma, posteriormente alterada pela Lei 24.782, criou uma forma de tutela específica que impõe ao agressor o dever de, a pedido do discriminado, tornar sem efeito o ato discriminatório ou cessar sua realização e ainda reparar os danos morais e materiais causados $^{350}$. O referido dispositivo, embora se dirija particularmente aos atos e omissões discriminatórios determinados por motivos tais como raça, nacionalidade, opinião política ou gremial, sexo, posição econômica, condição social ou características físicas, não veda sua aplicação à outras formas de discriminação que venham a surgir ${ }^{351}$. A lei estipulou ainda uma majoração de no mínimo um terço e no máximo metade em todas as penas previstas no Código Penal, se o delito for cometido por perseguição ou ódio a uma raça, religião ou nacionalidade, ou com o objetivo de destruir no todo ou em parte um grupo nacional, étnico, racial ou religioso ${ }^{352}$. Em seu artigo terceiro comina-se uma punição de um mês a três anos para os que participarem em uma organização ou realizarem propagandas baseadas em idéias ou teorias de superioridade de uma raça ou de um grupo de pessoas de determinada religião, origem étnica ou cor, que tenham por objeto a justificação ou promoção da discriminação racial ou religiosa de qualquer forma, cominando igual punição para quem, de qualquer

Dictar un régimen de seguridad social especial e integral en protección del niño en situación de desamparo, desde el embarazo hasta la finalización del período de enseñanza elemental, y de la madre durante el embarazo y el tiempo de lactancia. Disponível em: $<\mathrm{http} / / / \mathrm{www}$. senado.gov.ar/web/interes/constitucion/atribuciones.php>. Acesso em 12 de fevereiro de 2007.

${ }^{350}$ ARTÍ́CULO 1. Quien arbitrariamente impida, obstruya, restrinja o de algún modo menoscabe el pleno ejercicio sobre bases igualitarias de los derechos y garantías fundamentales reconocidos en la Constitución Nacional, será obligado, a pedido del damnificado, a dejar sin efecto el acto discriminatorio o cesar en su realización y a reparar el daño moral y material ocasionados. Disponível em: $<$ http://secretjurid.www5.50megs.com/leyes/lyspenal/23592_penal.htm $>$. Acesso em 12 de janeiro de 2007.

351 A los efectos del presente artículo se considerarán particularmente los actos y omisiones discriminatorios determinados por motivos tales como raza, religión, nacionalidad, ideología, opinión política o gremial, sexo, posición económica, condición social o caracteres físicos. Disponível em: $<$ http://secretjurid.www5.50megs.com/leyes/lyspenal/23592_penal.htm>. Acesso em 12 de janeiro de 2007.

${ }^{352}$ ARTÍCULO 2. Elévase en un tercio el mínimo y en un medio el máximo de la escala penal de todo delito reprimido por el Código Penal o leyes complementarias cuando sea cometido por persecución u odio a una raza, religión o nacionalidad, o con el objeto de destruir en todo o en parte a un grupo nacional, étnico, racial o religioso. En ningún caso se podrá exceder del máximo legal de la especie de pena de que se trate. . Disponível em: $<$ http://secretjurid.www5.50megs.com/leyes/lyspenal/23592_penal.htm $>$. Acesso em 12 de janeiro de 2007. 
modo alentar ou incitar a persecução ou o ódio contra uma pessoa ou grupo de pessoas por causa de sua raça, religião, nacionalidade ou idéias políticas ${ }^{353}$.

A Constituição italiana também estabelece o princípio da igualdade, dispondo no art. $3^{\circ}$ que os cidadãos têm a mesma dignidade social e são iguais perante a lei, sem distinção de sexo, raça, idioma, religião, opinião pública ou condições pessoais e sociais, além de estabelecer ser dever da República Italiana remover os obstáculos de ordem econômica e social, que, limitando de fato a liberdade e a igualdade dos cidadãos, impedem o pleno desenvolvimento da pessoa humana ${ }^{354}$. No art. 37, é vedada qualquer discriminação no trabalho em razão do sexo, ao se assegurar à mulher trabalhadora os mesmos direitos assegurados ao homem trabalhador, inclusive no tocante à igualdade de trabalho e a identidade de retribuição. estabelecida a igualdade de direitos de trabalho e de retribuição para a mulher trabalhadora $^{355}$.

Em termos de legislação infraconstitucional, na Itália merecem destaque as leis n. 125, de 10 de abril de $1991^{356}$, e n. 286, de 06 de março de 1998. A primeira delas disciplina as ações positivas para efetivação da igualdade entre homem e mulher no mercado de trabalho e cuida, entre outras coisas, de possibilitar o reembolso total ou parcial dos ônus que o empregador tiver para implementar as ações

353 ARTÍCULO 3. Serán reprimidos con prisión de un mes a tres años los que participaren en una organización o realizaren propaganda basados en ideas o teorías de superioridad de una raza o de un grupo de personas de determinada religión, origen étnico o color, que tengan por objeto la justificación o promoción de la discriminación racial o religiosa en cualquier forma.

En igual pena incurrirán quienes por cualquier medio alentaren o incitaren a la persecución o el odio contra una persona o grupos de personas a causa de su raza, religión, nacionalidad o ideas políticas. Disponível em: <http://secretjurid.www5.50megs.com/leyes/lyspenal/23592_penal.htm>. Acesso em 12 de janeiro de 2007.

${ }^{354}$ Art. 3. Tutti i cittadini hanno pari dignità sociale e sono eguali davanti alla legge, senza distinzione di sesso, di razza, di lingua, di religione, di opinioni politiche, di condizioni personali e sociali. È compito della Repubblica rimuoveri gli ostacoli di ordine economico e sociali, che limitando di fatto la libertà e la iguaglianza dei cittadini, impediscono il pieno sviluppo della persona umana e l'effetiva partecipazione di tuti lavoratori all'organizzazione polica, economica e sociale del Paese. Disponível em $<$ http://www.italianosenamerica.com/site/constituzione/costituzione.pdf $>$. Acesso em 10 de janeiro de 2007.

355 Art. 37. La donna lavoratrice ha gli stessi diritti e, a parità di lavoro, le stesse retribuzioni che spettano al lavoratore. Le condizioni di lavoro devono consentire l'adempimento della sua essenziale funzione familiare e assicurare alla madre e al bambino una speciale adeguata protezione. La legge stabilisce il limite minimo di età per il lavoro salariato. La Repubblica tutela il lavoro dei minori con speciali norme e garantisce ad essi, a parità di lavoro, il diritto alla parità di retribuzione. Disponível em $<$ http://www.italianosenamerica.com/site/constituzione/costituzione.pdf $>$. Acesso em 10 de janeiro de 2007. 
positivas $^{357}$, de prever tentativas de conciliação nas ações que visem a declaração de uma conduta discriminatória ${ }^{358}$. A segunda das citadas leis disciplina o tratamento recebido pelos imigrantes estrangeiros na Itália ${ }^{359}$.

Em Portugal o combate à discriminação alicerça-se nos artigos $13^{\circ}$ da Constituição. O número 1 do referido preceito estatui que "todos os cidadãos têm a mesma dignidade social e são iguais perante a lei”, enquanto o número 2 do mesmo preceito especifica alguns fatores em função dos quais fíca particularmente defesa qualquer discriminação, quais sejam: ascendência, sexo, raça, língua, território de origem, religião, convicções políticas ou ideológicas, instrução, situação econômica ou condição social. Segundo Júlia Campos, da Universidade Lusíada, “os fatores elencados nos artigos $13^{\circ}$ e $59^{\circ}$ da Constituição são meramente exemplificativos, albergando também todas as causas que possam fundamentar uma conduta discriminatória" ${ }^{\text {360 }}$. Em todo caso, como muito bem observa Catarina Oliveira Carvalho, a consagração do princípio da igualdade pelo referido preceito não consiste

356 Texto disponível em <http://www.italianosenamerica.com/site/constituzione/costituzione.pdf>. Acesso em 10 de janeiro de 2007.

357 Art. 2 (Attuazione di azioni positive, finanziamenti).

1. Le imprese, anche in forma cooperativa, i loro consorzi, gli enti pubblici economici, le associazioni sindacali dei lavoratori e i centri di formazione professionale che adottano i progetti di azioni positive di cui all'articolo 1, possono richiedere al Ministero del lavoro e della previdenza sociale di essere ammessi al rimborso totale o parziale di oneri finanziari connessi all'attuazione dei predetti progetti ad eccezione di quelli di cui all'articolo 3. Disponível em: <http://www.di-elle.it/Leggi/91-125.htm>. Acesso em $12 \mathrm{de}$ janeiro de 2007.

${ }_{358}^{4}$ 4. Chi intende agire in giudizio per la dichiarazione delle discriminazioni ai sensi dei commi 1 e 2 e non ritiene di avvalersi delle procedure di conciliazione previste dai contratti collettivi, può promuovere il tentativo di conciliazione ai sensi dell'articolo 410 del codice di procedura civile anche tramite il consigliere di parità di cui all'articolo 8 , comma 2, competente per territorio. . Disponível em: $<$ http://www.di-elle.it/Leggi/91-125.htm>. Acesso em 12 de janeiro de 2007.

${ }^{359}$ Art. 43.(Discriminazione per motivi razziali, etnici, nazionali o religiosi)

1. Ai fini del presente capo, costituisce discriminazione ogni comportamento che, direttamente o indirettamente, comporti una distinzione, esclusione, restrizione o preferenza basata sulla razza, il colore, l'ascendenza o l'origine nazionale o etnica, le convinzioni e le pratiche religiose, e che abbia lo scopo o l'effetto di distruggere o di compromettere il riconoscimento, il godimento o l'esercizio, in condizioni di parita', dei diritti umani e delle liberta' fondamentali in campo politico economico, sociale e culturale e in ogni altro settore della vita pubblica.

(...)

Art. 44. (Azione civile contro la discriminazione)

1. Quando il comportamento di un privato o della pubblica amministrazione produce una discriminazione per motivi razziali, etnici, nazionali o religiosi, il giudice puo', su istanza di parte, ordinare la cessazione del comportamento pregiudizievole e adottare ogni altro provvedimento idoneo, secondo le circostanze, a rimuovere gli effetti della discriminazione. Disponível em $<\mathrm{http} / / /$ www.parlamento.it/leggi/deleghe/98286dl.htm> . Acesso em 12 de janeiro de 2007.

${ }^{360}$ CAMPOS, Julia. Igualdade e não discriminação no direito do trabalho. In: IV Congresso Nacional de direito do trabalho. Coimbra: Livraria Almedina, 2002, p. 285. 
no único fundamento constitucional do combate à discriminação no acesso ao trabalho em razão do sexo em Portugal:

Este princípio aparece reforçado no título referente aos direitos e deveres econômicos, sociais e culturais; designadamente, no art. $58^{\circ}$., n 2, b), ao impor ao Estado a promoção da $<<$...igualdade de oportunidades na escolha da profissão ou gênero de trabalho e condições para que não seja vedado ou limitado, em função do sexo, o acesso a qualquer cargos, trabalho ou categorias profissionais $>>$, e no art. $59^{\circ}$., n. 1 , que proíbe a discriminação em razão do sexo quanto à retribuição, organização e prestação do trabalho ou categorias profissionais $>>$, e no art. $59^{\circ}$, n.1, que proíbe a discriminação em razão do sexo quanto à retribuição, organização e prestação do trabalho, repouso, assistência em situações de desemprego, acidente de trabalho ou doença profissional. Neste contexto, assumem igualmente relevância as prescrições resultantes do art. $68 .^{\circ}$, referente à questão da maternidade e paternidade, salientando o n. 3 a necessidade de garantir <<especial proteção [às mulheres] durante a gravidez e após o parto, tendo (...) direito a especial dispensa do trabalho por período adequado, sem perda de retribuição ou de quaisquer regalias $>>{ }^{361}$.

Em termos de legislação infraconstitucional, garantia o art. $4^{\circ}$ do CL n. 392/79<< < acesso às mulheres a qualquer emprego, profissão ou posto de trabalho $>>$, tornando nulas todas as normas legais e regulamentares, assim como, designadamente, as disposições presentes nos IRC, contratos individuais de trabalho ou regulamento interno da empresa, que limitem de algum modo este acesso ${ }^{362}$. O artigo $7^{\mathrm{o}}$ da referida norma não permite qualquer especificação ou preferência baseada no sexo em anúncio de oferta de emprego ou noutras formas publicitárias ligadas à seleção e recrutamento de trabalhadores. E como evidencia Catarina Oliveira Carvalho, de igual modo não se admite a exigência de requisitos físicos que não apresentem uma ligação directa com a profissão ou com as condições do se exercício, tratando-se, assim, de evitar discriminações indiretas, mediante a exigência de requisitos recorrentes, de modo exclusivo ou com maior freqüência, em apenas um dos sexos ${ }^{363}$.

\footnotetext{
${ }^{361}$ CARVALHO, Catarina Oliveira. Considerações sobre o estatuto jurídico-laboral da mulher. In: IV Congresso Nacional de direito do trabalho. Coimbra: Livraria Almedina, 2002, p. 129

362 Ibidem, p. 131

363 Ibidem, pp. 131/132.
} 
O recém editado Código do Trabalho daquele país, aprovado em 28 de julho de 2003 e cuja vigência teve início no dia primeiro de dezembro daquele mesmo ano dedica toda a subseção III, intitulada igualdade e não discriminação, ao tema ora estudado. Entre todas as normas lá inseridas, especial destaque deve ser dado ao artigo 23 que pró́be a discriminação estatuindo o seguinte:

O empregador não pode praticar qualquer discriminação, directa ou indirecta, baseada, nomeadamente, na ascendência, idade, sexo, orientação sexual, estado civil, situação familiar, património genético, capacidade de trabalho reduzida, deficiência ou doença crónica, nacionalidade, origem étnica, religião, convicções políticas ou ideológicas e filiação sindical.

Analisando o referido dispositivo, Estêvão Mallet ressaltou que "Embora o rol seja exemplificativo, o legislador procurou dar a máxima abrangência ao enunciado, mostrando que qualquer forma de discriminação desarrazoada está afastada do ponto de vista legal” ${ }^{364}$.

$\mathrm{Na}$ Espanha a vedação à discriminação encontra guarida no art. 14 da Constituição de 1978, que assegura igualdade perante a lei a todos os espanhóis e proíbe discriminações por motivo de nascimento, raça, sexo, religião, opinião, ou qualquer outra condição ou circunstância pessoal ou social. Amparado no referido dispositivo, o legislador do citado país introduziu, pela Lei Orgânica 4, de 1995, a tipificação criminal da discriminação, não somente a racista, mas de todos os outros tipos $^{365}$.

Segundo Vera Lúcia Carlos, na Constituição da Suécia de 1974 há normas expressas contra a discriminação étnica, determinando que sejam afastados da legislação ordinária sueca quaisquer elementos etnicamente discriminatórios, pondo em relevo os princípios da igualdade de todos os seres humanos, da liberdade e da dignidade que deve existir em uma nação politicamente organizada ${ }^{366}$. Com efeito, em seu art. 15 restou estabelecido que "nenhuma lei ou

\footnotetext{
${ }^{364}$ MALLET, Estêvão. Direito do trabalho e discriminação. In: Fórum Internacional sobre Direitos Humanos e Direitos Sociais. São Paulo: LTr, 2004. p. 356.

${ }^{365}$ CARLOS, Vera Lúcia. Op. cit., p. 48.

${ }^{366}$ Ibidem, p. 48.
} 
decreto poderá implicar discriminação de qualquer cidadão concernente a uma minoria por causa de sua raça, cor de pele, ou origem étnica"; e no seu art. 16 que "nenhuma lei ou decreto poderá implicar discriminação de qualquer cidadão quanto a seu sexo" 367 .

Atravessando o Atlântico de volta à América, cumpre analisar o combate à discriminação nos Estados Unidos, país marcado pela segregação racial onde os estudos sobre o tema tiveram grande desenvolvimento. Segundo Manoel Jorge e Silva Neto, a luta contra a discriminação no emprego teve início no governo de Franklin Roosevelt com a edição, em 1941, do Ato Executivo (Executive Order) n. 8.802, que atendeu as reivindicações do movimento negro contra atos discriminatórios e em prol de mais integração das pessoas negras no mercado de trabalho. Segundo o referido autor, a iniciativa presidencial não foi exitosa de fato por conta da ausência de apoio político no Congresso com relação à medida ${ }^{368}$.

Para ele, a luta contra a segregação racial somente assumiu nos Estados Unidos contornos de movimento político a partir da década de 60, através da conscientização dos cidadãos negros por força do trabalho de líderes do porte de Martin Luther King, James Forman e Malcom X. A atuação dos dois últimos distinguiu-se da ação do primeiro, na medida em que eles defendiam a adoção de mecanismos mais radicais para concretizar uma maior participação dos negros na vida do País, não descartando, inclusive, o recurso da violência ${ }^{369}$. Em todo caso, seja pela

\footnotetext{
${ }^{367}$ SILVA NETO, Manoel Jorge. Proteção constitucional dos interesses trabalhistas: difusos, coletivos e individuais homogeneos. São Paulo: LTr, 2001, p. 80. Na legislação infraconstitucional sueca, Vera Lúcia Carlos destaca, como instrumento de combate à discriminação, a tipificação dos seguintes delitos: Art. $8^{\circ}$. "Se uma pessoa publicamente ou de qualquer outro modo em uma declaração ou outra comunicação divulgada ao público ameaçar ou expressar desprezo por um grupo étnico ou qualquer outro grupo de pessoas em relação à raça, cor da pele, origem nacional ou étnica, ou credo religioso, será sentenciada por agitação contra o grupo étnico, estando sujeita a uma pena de prisão no máximo de dois anos ou, se a infração for de fraca gravidade delituosa, a pagar multa". Art. $9^{\circ}$, parágrafo $1^{\circ}$. "Se um homem de negócios na condução deles discriminar alguém, relativamente a sua raça, cor de pele, origem nacional ou étnica ou credo religioso, recusando negociar com ela nas mesmas condições que faz no tocante a outrem na condução de seus negócios, será sentenciado por discriminação ilegal \pagar uma multa ou a prisão de no máximo seis meses". Parágrafo 2o.: “As disposições no primeiro parágrafo, relativas aos empresários, serão aplicadas correspondentemente a uma pessoa que estiver empregada em um negócio ou que agir em nome de um empresário, bem como a uma pessoa considerada funcionário civil e que tiver de tratar com o público"; parágrafo $3^{\circ}$ : "O organizador de uma reunião ou de um espetáculo ou o seu auxiliar poderá ser sentenciado por discriminação ilegal, se discriminar alguém por causa de sua raça, cor da pele, origem nacional ou étnica, ou credo religioso, não lhe permitindo entrar na reunião ou no espetáculo nas mesmas condições aplicadas aos outros"CARLOS, Vera Lúcia. Op. cit., pp. $48 / 49$.

368 SILVA NETO, Manoel Jorge. Proteção...op. cit., p. 86.

369 Ibidem, p. 187.
} 
via do Manifesto de Forman, seja por meio da transformação pacífica defendida por Luther King, o movimento norte-americano desejava, em síntese, obter uma compensação pelos longos anos de exploração do trabalho negro escravo. O principal método encontrado pelo legislador ianque para efetivar esta compensação foi a adoção de "cotas especiais", como aconteceu com a Lei dos Direitos Civis e Políticos de $1964^{370}$.

Há que se ressaltar ainda que de acordo com estudos da Organização Internacional do Trabalho vem se observando, desde a publicação do seu primeiro informe global sobre discriminação no trabalho, intitulado La hora de la igualdad en el trabajo, em 2003, uma tendência a incluir nas legislações trabalhistas as quatro categorias de princípios e direitos fundamentais no trabalho da OIT. E mais. Além do maior reconhecimento da necessidade de promulgar leis especiais sobre a não discriminação e sobre a igualdade no lugar de trabalho, em vários países se vem constituindo organismos especializados, tanto estatais quanto não estatais, ou se reestruturando os antes existentes para ajudar supostas vítimas a tomar as medidas legais cabíveis. O estudo destaca ainda que a criação destes órgãos evidencia que se está adotando um enfoque mais amplo para promover a igualdade de oportunidades e de tratamento no trabalho. Exemplos desta mudança de enfoque seriam a criação, no México, do Conselho Nacional de Prevenção à Discriminação, que teria estreado a primeira política pública nacional de luta contra a discriminação em 2006; e, na Europa, a Diretiva sobre igualdade racial obriga os estados membros da União Européia a nomear um órgão nacional responsável por combater à discriminação ${ }^{371}$.

370 Ibidem, p. 187. Essa norma não foi, todavia, a única de grande relevância em matéria de combate à discriminação como evidencia a seguinte lição de Manoel Jorge e Silva Neto: "Em 1961, o Presidente John Kennedy expediu o Ato Executivo n. 10.925, determinando a todos os órgãos governamentais a inclusão de cláusulas de não-discriminaçao nos contratos, e em 1963 o Congresso promulgou o Equal Pay Act, tornando, via ação afirmativa, compulsório o tratamento igualitário a ser dispensado a homens e mulheres no âmbito da relação contratual de trabalho, admitindo, tão-somente, a legalidade de desequiparações com base em jornadas diferenciadas, tempo de serviço na função e pagamento de salário por tarefa (piece rate sustem), aquele que é pago ao operário tomando-se em conta o fator tempo, mas considerada a obrigação de produzir um resultado mínimo" (Ibidem, p. 86).

${ }^{371}$ Desde que se publicara el primer Informe global acerca de este tema, a escala mundial se ha venido observando una tendencia a incluir en las legislaciones laborales las cuatro categorías de principios y derechos fundamentales en el trabajo de la OIT. Además del mayor reconocimiento de la necesidad de promulgar leyes especiales sobre no discriminación y sobre la igualdad en el lugar de trabajo, en varios países se han constituido organismos especializados, tanto estatales como no estatales, o se han reestructurado los que ya existían, para ayudar a las presuntas víctimas a incoar acciones legales, para promover reformas o paraconcebir planes nacionales de acción de lucha contra la discriminación y controlar su aplicación. La creación de estos órganos evidencia que se está adoptando un enfoque más amplio para promover la igualdad de oportunidades y de trato en el trabajo. Buen ejemplo de ello es la 


\subsubsection{COMBATE À DISCRIMINAÇÃO NO DIREITO BRASILEIRO}

As condutas discriminatórias sempre foram contrárias ao ordenamento jurídico brasileiro. Como salienta Vera Lúcia Carlos, "O Sistema Constitucional Brasileiro, desde a Constituição de 25 de março de 1824, estabelece com regra geral a igualdade de todos perante a lei" ${ }^{372}$. Com efeito, a Constituição para o Império do Brasil de 25 de março de 1824, não obstante tenha sido elaborada em época em que ainda vigorava no Brasil a escravidão, estabelece, em seu artigo 260, que "A lei será igual para todos, quer proteja, quer castigue".

A Constituição Federativa dos Estados Unidos do Brasil de 24 de fevereiro de 1891, a primeira da era republicana, manteve o mesmo entendimento, estatuindo em seu artigo $72, \S 2^{\circ}$, que "Todos são iguais perante a lei” e que "A República não admite privilégio de nascimento, desconhece foros de nobreza, e extingue as ordens honoríficas existentes e todas as suas prerrogativas e regalias, bem como os títulos nobiliárquicos e de conselho".

Relevante avanço legislativo veio apenas com a Constituição da República dos Estados Unidos do Brasil, de 16 de julho de 1934, a qual, além de manter o princípio da igualdade formal, acrescentou ainda, de forma expressa, uma vedação à discriminação, em seu artigo 113, $1^{\circ}$, que dispunha que "todos são iguais perante a lei” e que "não haverá privilégios, nem distinções, por motivo de nascimento, sexo, raça, profissões próprias ou dos pais, classe social, riqueza, crenças

creación en México, en 2003, del Consejo Nacional de Prevención de la Discriminación, que estrenó la primera política pública nacional de lucha contra la discriminación en 2006. En Europa, la Directiva sobre igualdad racial obliga a los Estados miembros de la Unión Europea a nombrar un órgano nacional responsable de combatir la discriminación. Hasta la fecha, 19 países han modificado sus instituciones ampliando el mandato de las que ya existían o creando otras nuevas. En América Latina, la lucha contra las desigualdades raciales y étnicas descuella en los programas públicos de varios países. Este es el caso del Brasil, donde se ha creado, con rango ministerial, una secretaría especial encargada de las políticas de promoción de la igualdad racial. (ORGANIZAÇÃO INTERNACIONAL DO TRABALHO (OIT). $L a$ igualdad...op.cit., p. 10).

${ }^{372}$ CARLOS, Vera Lúcia. Op. cit., p. 37. 
religiosas ou idéias políticas". Todavia, segundo pondera Vera Lúcia Carlos acerca da Constituição de 1934, "a proibição de discriminações, reconhecida no texto legal, permaneceu de uma forma simbólica, pois, em artigos que se seguem a esses, na própria Constituição, verifica-se marcantes traços de racismo". E exemplifica com o artigo 138, que estabelecia como dever da União, dos Estados e das Municipalidades a promoção da educação eugênica, que nada mais era do que o controle e, em alguns casos, a eliminação de certos tipos biológicos, com vistas a alcançar um ideal de homogeneidade física ou racial ${ }^{373}$.

$\mathrm{Na}$ Constituição dos Estados Unidos do Brasil o princípio da igualdade sofreu uma simplificação, voltando a se resumir ao imperativo de igualdade formal, “todos são iguais perante a lei”.

No tocante à Constituição dos Estados Unidos do Brasil, de 18 de setembro de 1946, cumpre transcrever, uma vez mais, os ensinamentos de Vera Lúcia Carlos, para quem este documento foi o primeiro a estabelecer constitucionalmente o parâmetro antidiscriminatório da nacionalidade, na medida em que, além de reafirmar o princípio da igualdade, atestou ainda a não-aceitação de qualquer tipo de propaganda veiculadora de preconceitos de raça ou de classe ${ }^{374}$. É o que se depreende dos seguintes dispositivos:

Art. 141. A Constituição assegura aos brasileiros e aos estrangeiros residente no país a inviolabilidade dos direitos concernentes à vida, à liberdade, à segurança individual e à propriedade, nos termos seguintes:

$\S 1^{\mathrm{o}}$. Todos são iguais perante a lei.

(...)

$\S 5^{\circ}$. É livre a manifestação do pensamento, sem que dependa de censura, salvo quanto a espetáculos e diversões públicas, respondendo cada um, nos casos e na forma que a lei preceituar, pelos abusos que cometer. Não é permitido o anonimato. É assegurado o direito de resposta. A publicação de livros e periódicos não dependerá de licença do poder público. Não será, porém, tolerada propaganda de guerra, de processos violentos para subverter a ordem pública e social, ou de preconceitos de raça ou de classe.

\footnotetext{
${ }^{373}$ Ibidem, p. 38.

${ }^{374}$ Ibidem, p. 38 .
} 
As Cartas Magnas de 1967 e 1969 mantiveram a prescrição da igualdade entre todos os direitos e garantias fundamentais do ser humano. Nesta última, acentuou-se ainda que aqueles que praticassem preconceito de raça estariam sujeitos a punição, incluindo-se dispositivo estabelecendo que não seria tolerada a propaganda que veiculasse preconceito de religião, acrescentando-se, também, que não seria permitida a realização de publicações e exteriorizações contrárias à moral e aos bons costumes.

Analisando o tratamento constitucional dado à proibição da discriminação nas relações de trabalho, Octávio Bueno Magano e Estêvão Mallet enalteceram a evolução havida no Direito Constitucional brasileiro, observando que enquanto na Constituição de 1946 só se falava na proibição de diferença de salário para um mesmo trabalho; na de 1967 e Emenda n. 1, de 1969, aludiu-se à proibição de diferença de salários e critérios de admissões e, finalmente, na de 1988, proibiu-se diferenças de salários, de exercício de funções e de critérios de admissão ${ }^{375}$.

Vera Lúcia Carlos observa que "A Magna Carta vigente modifica a concepção de Estado, que passa de imperativo, de coator, a interventor, organizador, previdenciário etc" ${ }^{376}$. Em sua opinião a importância nela atribuída ao tema da igualdade e, conseqüentemente, do combate à discriminação pode ser percebida na medida em que logo em seu preâmbulo o legislador constituinte originário incluiu, como uma das metas do Estado Democrático, assegurar uma sociedade pluralista e sem preconceitos. Tema, aliás, que restou retomado em vários artigos inseridos na Lei Maior, entre eles: art. $1^{\circ}$, inciso III, art. $3^{\circ}$, incisos III e IV; art. $4^{\mathrm{o}}$, inciso VIII; art. $5^{\circ}$, incisos XLI e XLII, $\S \S 1^{\circ}$ e $2^{\mathrm{o}}$; art. $7^{\circ}$, incisos XXX e XXXI e XXXII; art. 19, incisos I e III; art. 60, $\S 4^{\circ}$, inciso IV; art. $215, \S \S 1^{\circ}$ e $2^{\text {o }}$; art. 216 , incisos I, II, III, IV, V e $\S 5^{\circ}$; art. 242, $\S 1^{\text {o; }}$; e art. 68 das disposições transitórias ${ }^{377}$.

Segundo Octávio Bueno Magano e Estêvão Mallet, “A não discriminação, tema do art. $7^{\circ}, \mathrm{XXX}$, da Constituição, não implica apenas a

\footnotetext{
${ }^{375}$ MAGANO, Octávio Bueno e MALLET, Estêvão. Op. cit., p. 163.

${ }^{376}$ CARLOS, Vera Lúcia. Op. cit., p. 40.

${ }^{377}$ Ibidem, p. 41.
} 
proibição de diferenças salariais, mas também tratamentos desiguais, no que tange ao exercício de funções e admissões em empregos" ${ }^{\text {378 }}$.

Em termos de legislação infraconstitucional, cumpre ressaltar o papel desempenhado pela sexagenária Consolidação das Leis do Trabalho no combate a discriminação. Com efeito, consta de seu texto desde sua elaboração e promulgação uma série de preceitos antidiscriminatórios. Em seu artigo $3^{\circ}$ restou estabelecido que não haverá distinções relativas à espécie de emprego e à condição de trabalhador, nem entre o trabalho intelectual, técnico e manual. O seu artigo $5^{\circ}$, por sua vez, estatuiu que a todo trabalho de igual valor corresponderá igual salário, sem distinção de sexo, preceito que acaba por ser assegurado no artigo 461. Por fim, cumpre ressaltar ainda o artigo 373-A, que veda as práticas discriminatórias contra a mulher.

Até mesmo a proteção conferida ao cipeiro e ao dirigente sindical revestem-se de caráter antidiscriminatórias. Afinal, como salienta Paulo Jakutis, "a garantia de emprego desses dois trabalhadores se justifica (aceitação pela sociedade) sob o fundamento de que ela é, em verdade, uma proteção contra a discriminação do empregador" ${ }^{379}$. Isto porque, não houvesse essa proteção, poderiam eles ser discriminados em razão de seu mister, respectivamente, de levantar falhas na segurança e nas condições de trabalho, e de organização de trabalhadores para buscarem benefícios que muitas vezes resultam em diminuição dos lucros patronais.

Fora da CLT, há uma série de textos legais de diversas naturezas que cuidam da vedação à discriminação.

A Lei 5.473/68 estatui em seu artigo $1^{\circ}$ serem nulas as disposições e providências que direta ou indiretamente criem discriminações entre brasileiros de ambos os sexos para o provimento de cargos sujeitos a seleção, assim nas empresas privadas como nos quadros do funcionalismo federal, estadual e municipal, do serviço autárquico, de sociedade de economia mista e de empresas concessionárias de serviço público. A pena cominada para os casos de violação deste dispositivo varia

\footnotetext{
${ }^{378}$ MAGANO, Octávio Bueno e MALLET, Estêvão. Op. cit., p. 163.

379 JAKUTIS, Paulo. Op. cit., p. 116.
} 
de três meses a um ano para quem obstar ou tentar obstar o cumprimento do disposto nesse artigo (parágrafo único do referido dispositivo). A Lei 7.670/88, por sua vez, estende os benefícios aos portadores do vírus HIV,

Em matéria penal há a Lei n. 7.716, de 5 de janeiro de 1989, que, conforme sua ementa, "Define os crimes resultantes de preconceito de raça ou de cor". Contudo, como destaca José Cláudio Monteiro de Brito Filho, "na verdade, além da raça e da cor, a lei protege, ainda, as etnias, a religião e a procedência nacional ${ }^{\prime 380}$. O referido autor critica a lei em questão por entender impossível a tentativa de punibilidade do preconceito, por não ser esta uma categoria jurídica de análise. A punição, segundo seu entendimento, somente poderia ser dirigida à conduta capaz de ser regulada pelo Direito, qual seja: a discriminação ${ }^{381}$.

Já a lei $7.853 / 89$ proíbe a discriminação contra pessoas portadoras de deficiência $\left(\operatorname{art.} 1^{\circ}, \S 2^{\circ}\right)$.

A Lei 8.112/90, que instituiu o Regime Jurídico Único da União, bem como a Lei Complementar 683/92 prevêem a reserva de vagas de concursos públicos às pessoas portadoras de deficiência. Mais uma vez cumpre invocar os ensinamentos de José Cláudio Monteiro de Brito Filho, para quem essa lei tem perfil nitidamente distinto das anteriores, abandonando o caráter puramente repressor para fixar cotas que devem ser preenchidas com pessoas com características determinadas: ser trabalhador reabilitado ou portador de deficiência ${ }^{382}$. Aduz ainda que "quando as cotas são fixadas a situação é alterada, presumindo-se que essa inserção compulsória dê origem, em determinado momento, a uma inserção consolidada e que não precise, mais, ser estimulada" ${ }^{383}$.

A Lei $8.842 / / 94$, por sua vez, proíbe a discriminação contra o idoso (art. $3^{\circ}$, III).

\footnotetext{
${ }^{380}$ BRITO FILHO, José Cláudio Monteiro de. Op. cit., p. 63.

${ }^{381}$ Ibidem, p. 64.

${ }^{382}$ Ibidem, p. 66.

${ }^{383}$ Ibidem, p. 67.
} 
Por fim, a Lei 9.029/95 consiste no principal diploma sobre o assunto. Esta norma, composta por apenas 6 artigos foi inovadora em diversos aspectos. Primeiramente, ela criou uma possibilidade de retorno compulsório ao emprego desvinculada de qualquer forma de estabilidade, subvertendo a tradição de que a anulação da dispensa e a reintegração no emprego estavam umbilicalmente vinculadas à estabilidade jurídica ${ }^{384}$. Consoante leciona Sérgio Torres Teixeira, essa inovação legislativa desencadeou "o surgimento de uma nova espécie de medida restritiva o direito de despedir, dirigida especificamente contra uma modalidade peculiar de despedida, a dispensa abusiva" ${ }^{285}$.

A despedida ou dispensa do empregado, ato jurídico unilateral, potestativo, receptivo e constitutivo negativo, através do qual o empregador exerce o seu direito direito subjetivo de resilir o contrato individual de trabalho, passou então a sofrer limitações outras que não a estabilidade no emprego. Com isso, o ato empregatício de provocar a rescisão contratual sem ter havido falta do empregado, para o qual o direito brasileiro não exige a apresentação dos motivos que o determinaram, mas tão-somente o pagamento de uma indenização pecuniária; passou expressamente a ter que se vincular a fins legítimos, sob pena de ser considerado nulo, como a seguir será demonstrado.

Como salienta Christiani Marques, a Lei n. 9.029/95 foi o primeiro instrumento normativo infraconstitucional criado para proteção do empregado no âmbito das relações de trabalho visando vedar a prática discriminatória que estabeleceu, expressamente, a anulabilidade da dispensa fundada na referida prática $^{386}$.

\footnotetext{
${ }^{384}$ Como salienta Sérgio Torres Teixeira: Tradicionalmente o legislador pátrio cuidou apenas da medida restritiva típica, a estabilidade jurídica no emprego. Até recentemente era pacífico nos meios forenses trabalhistas, assim, que tão somente o empregado "estável" estaria em condições de adequadamente postular a anulação de sua dispensa e o seu retorno ao antigo emprego, e, ainda, desde que ausente um ou mais dos pressupostos exigidos em lei para o correto exercício do direito de despedir. Unicamenteo "estabilitário" estava a salvo. A anulação da dispensa e a reintegração no emprego, estavam, era costume afirmar, "umbilicalmente" ligados à estabilidade jurídica no emprego. (TEIXEIRA, Sérgio Torres. Proteção à relação de emprego. São Paulo: LTr, 1998, p. 16.)

${ }^{385}$ Ibidem, p. 16.

${ }^{386}$ MARQUES, Christiani. Op. cit., p. 63.
} 
A lei em questão também foi inovadora ao, em seu artigo $4^{\circ}$, conferir ao empregado discriminado, e não ao juiz que analisar o caso, a prerrogativa de optar entre o retorno ao serviço e a indenização ${ }^{387}$.

Vera Lúcia Carlos, destaca a este respeito que a Lei 9.029/95, ao proibir práticas discriminatórias, é exemplo único de norma que prevê reparação como forma de compensar o dano moral sofrido pelo trabalhador, permitindo-lhe optar pela readmissão ou pelo ressarcimento. Ambas as reparações não têm natureza indenizatória trabalhista, mas sim a finalidade de reparar o trabalhador discriminado ${ }^{388}$.

Outro ponto bastante positivo da lei consistiu na estipulação de uma multa administrativa de dez vezes o maior salário pago pelo empregador, elevado e 50\% (cinqüenta por cento) em caso de reincidência. Pena que não venha ela sendo aplicada corriqueiramente pela fiscalização do trabalho. Uma possível explicação para a pouca utilização deste importante mecanismo no combate a discriminação é a dificuldade de caracterização da discriminação no trabalho. Afinal, se é difícil caracterizar e comprovar uma prática discriminatória em um processo judicial, o que se dirá de sua caracterização em uma investigação administrativa. De toda sorte, se todos os juízes expedirem ofícios ao Ministério do Trabalho após o reconhecimento de uma conduta discriminatória para que este, aí sim sem mais espaços para discussão, aplique a referida sanção, sem prejuízo de eventual indenização aplicada na Justiça Especializada, o impacto econômico sobre o agressor seria maior, o que poderia resultar em uma redução na incidência desta prática censurável. Afinal, como leciona Estêvão Mallet, as práticas discriminatórias nunca serão combatidas apenas com ações afirmativas e com processos individuais em que haja a reparação da lesão. Em sua opinião é preciso se pensar cada vez mais na possibilidade de imposição de sanções econômicas para desestimular as práticas contrárias ao direito ${ }^{389}$.

\footnotetext{
${ }^{387}$ É o que destaca José Cláudio Monteiro de Brito Filho na seguinte passagem "Ressalte-se porém que, para o empregado estável, o direito é o de reintegração, e, apenas se o juiz entender desaconselhável o retorno, sua conversão em indenização; já para o empregado discriminado a opção existe sem condicionantes, e é o empregado quem decide qual das alternativas lhe é desejável" BRITO FILHO, José Cláudio Monteiro de. Op. cit., p. 64.

${ }^{388}$ CARLOS, Vera Lúcia. Op. cit., , p. 56.

${ }^{389}$ MALLET, Estêvão. Op. cit., pp. 362/363.
} 
A despeito de todos esses avanços, a referida norma, em razão, sobretudo, da sua redação, gerou também uma série de polêmicas. A primeira diz respeito à utilização do epíteto readmissão e não reintegração. Não há na doutrina consenso quanto aos efeitos da utilização da expressão readmissão utilizada pelo artigo $4^{\circ}$ da Lei 9.029/95. Parte da doutrina entende que o legislador queria efetivamente falar em reintegração, e, por isso, defende ser ela aplicável, com todos os efeitos que the são inerentes e quem, interpretando literalmente o dispositivo, entenda que o empregado discriminado deve efetivamente ser readmitido, com as conseqüências que daí advém.

Cumpre, inicialmente, destacar as diferenças entre os dois termos. O epíteto readmissão denota uma nova contratação. A formação de um novo vínculo, razão pela qual o lapso temporal em que o empregado não esteve efetivamente trabalhando não deve ser contado para nenhum fim. Pressupõe também um novo acordo de vontades. A reintegração, por sua vez, denota medida coercitiva na qual o empregador é compelido judicialmente a ofertar novamente trabalho ao empregado dispensado, contando-se para todos os fins o período de afastamento. Sob essa ótica, haveria que se reconhecer ter incorrido em equívoco o legislador que inseriu o epíteto readmissão onde deveria constar reintegração. O texto legal é claro ao estabelecer que, optando o empregado pelo retorno ao serviço, o empregador é obrigado a recebê-lo, o que, por si só, afasta a caracterização da readmissão. Prevalece exclusivamente a vontade de uma das partes. Ademais, se as verbas do período de afastamento são devidas ao empregado, não é concebível que não haja contagem do período de afastamento.

José Cláudio Monteiro de Brito Filho, embora reconheça que readmitir é admitir novamente, compartilhando da opinião de que este não parece ser o objetivo da Lei, e sim a reintegração, qual seja, o ato de integrar novamente o empregado tenda-se o rompimento do vínculo e determinando-se o pagamento da contraprestação e de seus consectários, pugna pela aplicação da norma em sua literalidade ${ }^{390}$.

${ }^{390}$ De qualquer sorte, como o vocábulo readmissão tem um conteúdo próprio, e foi este o utilizado pela Lei, forçoso entender que o empregado 'readmitido' terá novo contrato de trabalho, fazendo jus a todos os direitos de natureza pecuniária do período denominado como de afastamento, mas sem direito da 
Esta não parece ser a solução mais acertada. Restando evidenciado ter havido erro material na redação do dispositivo e saltando aos olhos que tanto a mens legislatoris quanto a mens legis eram no sentido de determinar a reintegração, nada justifique a aplicação literal do dispositivo. Admitir o contrário resulta em permitir que o empregador se beneficie de sua torpeza deixando de reconhecer ao trabalhador abusivamente dispensado os direitos decorrentes da contagem do tempo de serviço deste período.

Francisco Gérson Marques, por sua vez, defende que a legislação teria criado uma nova forma de readmissão. Em seu magistério, não se trata de reintegração porque o trabalhador não era estável no emprego (art. 492, CLT); $2^{\circ}$ ); não foi ajuizado nenhum inquérito judicial pra verificar o cumprimento de falta grave (art. 853, CLT); não foi a Justiça quem obrigara o empregador a optar pela denominada readmissão (art. 496, CLT), pois isto é faculdade do prestador de serviço (art. $4^{\circ}$, caput , Lei n. 9.029/95); e a norma isonômica denominou o fenômeno de readmissão, expressamente. Tampouco admite se tratar da tradicional readmissão, porquanto o retorno ao emprego pode resultar de uma ação judicial (e, por certo, em regra resultará de reclamação trabalhista), onde se faculte ao empregado a opção; há o pagamento das remunerações de todo o período de afastamento; não se refere ao obreiro que pediu demissão, mas, sim, apenas àquele que fora despedido pelo empregador; sendo a opção do empregado, pouco importa a aquiescência do empregador para a readmissão forçada que é. ${ }^{391,}$

Feitas estas considerações, defende que na por ele chamada readmissão indenizada, hibridismo da readmissão simples e da reintegração, há contagem do tempo de serviço durante o qual o obreiro esteve injustamente afastado do emprego, haja vista a Lei 9.099/95 ser expressa acerca do ressarcimento integral de todo o período de afastamento ${ }^{392}$. Em outras palavras, embora atribuindo ao instituto uma nomenclatura diferente o referido autor reconhece-lhe a aplicabilidade dos efeitos inerentes à reintegração quanto ao computo do tempo de afastamento.

${ }^{391}$ LIMA, Francisco Gérson Marques de. Op cit. p. 193/194. 
Já Marcelo Alessi defende que a dispensa discriminatória deve ser declarada nula e, por conseguinte, não deve gerar qualquer efeito no mundo jurídico em virtude de só serem possíveis às hipóteses de rescisão contratual previstas na CLT, quais sejam, dispensa por justa causa e dispensa sem justa causa $^{393}$.

O que se pode concluir destas observações é que, ainda que pelos mais diversos fundamentos e, em determinados casos fazendo uso de nomenclaturas diversas, a maior parte da doutrina defende a contagem do tempo o período de afastamento nos casos de dispensa discriminatória tornada sem efeito por decisão judicial.

Outra controvérsia surgida em torno da Lei 9.029/95 diz respeito ao rol do seu artigo $1^{\circ}$. A redação empregada não deixa claro se ele é taxativo ou exemplificativo. Isto porque, embora se determine ficar proibida a adoção de qualquer prática discriminatória e limitação do acesso à relação de emprego ou sua manutenção, o que daria a entender que são vedadas todas as formas possíveis de discriminação, logo em seguida fala-se em "por motivo de sexo, origem, raça, cor, estado civil, situação familiar ou idade", sem se utilizar expressões como "por exemplo" e sem encerrar o rol com reticências, o que poderia ser interpretado como taxatividade do elenco aduzido. Passados alguns anos, há que se registrar que doutrina e jurisprudência majoritárias são uníssonas em considerar o referido rol exemplificativo, podendo empregados dispensados de forma discriminatória não inserida no rol, pleitear sua readmissão (reintegração) com base no artigo $4^{\circ}$ da citada $1 \mathrm{ei}^{394}$.

\footnotetext{
${ }^{392}$ MARQUES, Christiani. Op. cit., p. 194.

${ }^{393}$ É o que se depreende do seguinte estrato de seu texto: "Não existe modalidade de rescisão contratual por motivo de discriminação. Por isso, como o empregador não pode rescindir o contrato de trabalho por motivo não previsto em lei, a dispensa discriminatória é nula. Não só por isso seria nula, mas também por infringir um direito fundamental arraigado na Constituição Federal. Assim, devida a reintegração no emprego ao empregado afastado por motivo de discriminação, com o pagamento dos salários e garantia das vantagens do período de afastamento como se a mesma não tivesse ocorrido" ALESSI, Marcelo. Discriminação do direito do trabalho - aspectos legais e jurisprudenciais". In: Transformações do direito do trabalho - estudos em homenagem ao professor Doutor João Regis Fassbender Teixeira. Coords. Aldacy Rachid Coutinho e José Affonso Dallegrave Neto. Curitiba: Juruá, 2000, p. 64).

394 Neste sentido é o magistério de Christiani Marques: "Não obstante a Lei n. 9.029/95 não ter mencionado outros fatores discriminatórios, não significa dizer que os mesmos estão sem eficácia
} 
E ainda que se entenda que o rol em questão é taxativo, não sendo a lei aplicável a outras formas de discriminação, é possível, com base na já referida teoria da aplicação imediata dos direitos fundamentais às relações particulares se invalidar judicialmente a dispensa discriminatória aplicando-se diretamente o postulado constitucional da igualdade ${ }^{395}$.

Como se vê, no Direito brasileiro não faltam mecanismos para combater a discriminação praticada no momento da rescisão contratual. No que se refere à discriminação perpretada por ocasião da formação da relação de emprego, cumpre ponderar ser ela passível de reparação pecuniária compensatória, nos termos do artigo 186 e 927 do Código Civil de 2003.

Quanto às práticas discriminatórias perpetradas no decorrer da relação empregatícia, tanto se pode ter uma reparação de natureza trabalhista, como, por exemplo, uma reclamação com pedido de equiparação salarial, quanto uma ação de reparação por danos morais nos termos do direito civil. Embora estas medidas pudessem ser tomadas enquanto em curso o contrato de trabalho, em geral elas somente são adotadas após o término do vínculo de emprego. Afinal, como pondera José Cláudio Monteiro de Brito Filho, a Justiça do Trabalho é uma justiça de desempregados, na medida em que "não tendo nenhuma proteção contra a despedida arbitrária, dificilmente o trabalhador, quando ainda em curso sua relação de emprego, busca a solução de seus conflitos com o empregador" 396.

Há que se ressaltar ainda que o legislador brasileiro utiliza a lei penal com o intuito de solucionar o problema da discriminação desde 1951, quando foi promulgada a chamada Lei Afonso Arinos (Lei 1.390 de 1951). Contudo,

sancionatória. Violado um direito fundamental, o mesmo deve ser tutelado. Talvez o legislador tenha perdido a oportunidade de ser menos acanhado, em 1995, ao deixar de mencionar outras práticas discriminatórias"(Op. cit., p. 74).

${ }^{395}$ Mais uma vez válidas são as lições de Christiani Marques: "Todavia, mesmo em face da lacuna legal, há entendimento de que a proteção contra a dispensa independe de regulamentação infraconstitucional, pois a conduta de discriminação praticada pelo empregador é abusiva e arbitrária, não viola apenas um direito trabalhista, mas transgride um princípio constitucional fundamental da dignidade humana, além de sua intimidade e, por conseqüência, deverá o empregador reparar os prejuízos sofridos” (Ibidem, p. 67).

${ }^{396}$ BRITO FILHO, José Cláudio Monteiro de. Op. cit., p. 71. 
como observa Kátia Elenise Oliveira da Silva, "até o momento não tem encontrado o sucesso desejado, pois a eficácia das leis antidiscriminatórias penais é muito precária"397.

A Carta Magna determina que não só será punida qualquer discriminação atentatória aos direitos e liberdades fundamentais - artigo $5^{\circ}$, inciso XLI, da CF, bem com estipula que a prática do racismo passa a ser crime imprescritível e inafiançável - artigo $5^{\circ}$, inciso XLII, da CF. Após o início de sua vigência, o legislador ordinário já expediu quatro leis tipificando os delitos de discriminação: Lei 7.716, de 05/01/89; Lei 8.081, de 21.09.90; Lei 8.882, de 03/06/94 e Lei 9.459, de 13/05/97, sendo que as últimas modificaram a primeira.

No Brasil, o Governo Federal tornou-se parceiro do referido Organismo Internacional no denominado Programa de Fortalecimento Institucional para a Igualdade de Gênero e Raça, Erradicação da Pobreza e Geração de Emprego (GRPE), concebido pela Organização Internacional do Trabalho (OIT), versão brasileira do $\mathrm{GPE}^{398}$. O material informativo da própria Organização Internacional do Trabalho destaca:

A incorporação da dimensão racial no Brasil se deve ao
reconhecimento da importância dessa variável na
determinação da situação de pobreza e na definição dos
padrões de emprego e desigualdade social. O objetivo
principal do GRPE no Brasil é apoiar a incorporação e o
fortalecimento das dimensões de gênero e raça nas políticas
de erradicação da pobreza e de geração de emprego - ação
considerada estratégica para reduzir a incidência da pobreza,
diminuir as desigualdades de gênero e raça, assim como os
déficits de trabalho decente atualmente existentes no país.
Os primeiros passos relativos à implementação do GRPE no
Brasil foram dados no ano de 2000, em um trabalho
conjunto entre a OIT, o Ministério do Trabalho e Emprego,
a Prefeitura Municipal de Santo André/SP (que se iniciou na
Assessoria dos Direitos da Mulher e depois envolveu várias
secretarias dessa prefeitura) e o Governo do Estado de
Pernambuco. Contou com a assessoria do Centro de Estudos
das Relações de Trabalho e Desigualdades (CEERT) para o
desenvolvimento do componente racial. A criação da
Secretaria Especial de Política de Promoção da Igualdade

${ }^{397}$ SILVA, Katia Elenise Oliveira da. O papel do direito penal no enfrentamento da discriminação. Livraria do advogado editora: Porto Alegre, 2001, p. 13.

${ }^{398}$ ORGANIZAÇÃO INTERNACIONAL DO TRABALHO (OIT). Manual...op. cit., 1v., p. 3. 
Racial (SEPPIR) em março de 2003, foi um fator fundamental para projetar o programa a nível federal. Em outubro de 2003 o Programa foi lançado oficialmente no Brasil, com a assinatura de um Protocolo de Intenções estabelecendo compromissos entre a OIT e o Governo Federal . A base institucional para a assinatura deste Protocolo foi o Memorando de Entendimentos firmado entre o Presidente da República Federativa do Brasil e o Diretor Geral da OIT, em julho de 2003, estabelecendo um marco para o desenvolvimento de um Programa de Cooperação Técnica no Brasil com o objetivo de promover uma Agenda de Trabalho Decente. Posteriormente, em 2004, foram assinados Protocolos de Intenções com a Câmara Regional do Grande ABC e com a Prefeitura Municipal de São Paulo para a implementação do GRPE nessas regiões ${ }^{399}$.

A criação da Secretaria Especial de Política de Promoção da Igualdade Racial (SEPPIR) em março de 2003, aliás, foi apontada no Informe Global de 2007 da OIT como um exemplo de política governamental de constituição ou reestruturação de organismos especializados ou comissões encarregadas de prestar assistência jurídica às vítimas de discriminação, ou de facilitar informação e pautas de orientação a empregadores sobre a maneira de conferir aos seus sistemas salariais maior transparência e neutralidade ${ }^{400}$.

Vê-se, portanto, que também no Brasil o combate à discriminação no emprego já não se limita à edição de leis que tornam ilegítimas condutas discriminatórias, cominando sanções para as hipóteses de descumprimento.

\subsubsection{PROTEÇÃO JURISDICIONAL CONTRA A DISCRIMINAÇÃO}

Segundo observa José Cláudio Monteiro de Brito Filho, "Não obstante deva ser a última alternativa, dentre as possíveis para o combate à discriminação, a solução jurisdicional constitui meio eficaz para estancar condutas

\footnotetext{
${ }^{399}$ Ibidem, p. $3 / 4$.

400 En los cuatro últimos años se han constituido o reestructurado organismos especializados o comisiones encargados de prestar asistencia jurídica a las víctimas de discriminación, o de facilitar información y pautas de orientación a los empleadores sobre la manera de conferir a sus sistemas salariales mayor transparencia y neutralidad en términos de género. Valga destacar a modo de ejemplo que en el Brasil, donde el 46 por ciento de la población es de raza negra, se creó en 2003, con rango
} 
lesivas, no tocante à matéria em discussão" ${ }^{401}$. Vera Lúcia Carlos defende em sua obra que a tutela jurisdicional contra atos discriminatórios de regra deve ser buscada individualmente pelo titular do direito lesado que, para tanto, poderá valer-se dos preceitos contidos na Lei $9.029 / 95^{402}$. Não se pode, contudo, deixar de ressaltar a importância da jurisdição coletiva ${ }^{403}$.

A importância da jurisdição coletiva para o combate à discriminação é também econômica. Como salienta José Cláudio Monteiro de Brito Filho, as ações coletivas são também vantajosas porque "seu uso importa redução dos custos que o estado tem com a máquina judiciária, dão segurança às relações sociais e conduzem à uniformização da solução para conflitos idênticos, evitando situações e tratamentos desiguais" ${ }^{404}$. Ademais, neste tipo de ação "a segurança das relações sociais, por sua vez, é alcançada com uma solução única e, presumivelmente, mais célere e capaz de, de uma vez só, dar fim a todos os conflitos surgidos com único ato do empregador, muito embora dirigido contra diversos trabalhadores" 405.

O Ministério Público do Trabalho, aliás, antes mesmo do ajuizamento da ação civil pública, possui interessantes mecanismos de combate à discriminação, que são os seus procedimentos administrativos internos que podem sepultar a controvérsia através da subscrição de Termo de Ajustamento de Conduta ${ }^{406}$.

ministerial, la Secretaría Especial de Políticas de Promoción de Igualdad Racial (SEPPIR). (ORGANIZAÇÃO INTERNACIONAL DO TRABALHO (OIT). La igualdad... op cit., p. 20)

${ }^{401}$ BRITO FILHO, José Cláudio Monteiro de. Op. cit., p. 70.

${ }^{402}$ CARLOS, Vera Lúcia. Op. cit., p. 54.

403 existe toda uma gama de instrumentos a utilizar, reunidos dentro do que se pode chamar 'ações de massa': a ação civil pública; a ação civil coletiva; a ação anulatória; a reclamação trabalhista em que o sindicato atua como substituto processual, entre outras. Essa multiplicidade, observe-se, não importa o uso aleatório das ações, pois, como veremos mais adiante, existem fatores que indicam qual o meio a utilizar, como o interesse a proteger, a natureza do conflito que se pretende solucionar e o provimento que se pretende obter (BRITO FILHO, José Cláudio Monteiro de. Op. cit., p. 73).

${ }^{404}$ Ibidem, p. 73.

${ }^{405}$ Ibidem, p. 74.

${ }^{406}$ É o que destaca Ana Emília Andrade Albuquerque da Silva: "o Ministério Público do Trabalho, na esfera da discriminação no trabalho, como nas demais áreas de sa competência, recebendo denúncia a respeito ou tendo notícia de sa ocorrência, instaura inquérito civil para sua apuração, com vistas à verificação de sua veracidade. Constatada a discriminação, o Ministério Público do Trabalho propõe ao transgressor o chamado Termo de Compromisso de Ajustamento de Conduta, previsto na Lei de Ação Civil Pública, com natureza de título executivo extrajudicial, podendo ser executado perante uma das Varas do Trabalho". (SILVA, Ana Emília Andrade Albuquerque da. Discriminação racial no trabalho. São Paulo: LTr, 2005, p. 49). 
Sistema interessante de combate à discriminação é o desenvolvido na Suécia. Segundo Manoel Jorge e Silva Neto, "Se as normas constitucionais suecas encerram forte reação contra os procedimentos discriminatórios, a legislação infraconstitucional também não fica no compasso de espera relativamente à tutela de interesses de tamanha amplitude" ${ }^{407}$. A Suécia possui um sistema eficaz e singular quanto à proteção dos interesses difusos, notabilizado a partir da instituição do Ombudsman ${ }^{408}$.

Analisando este sistema Manoel Jorge e Silva Neto, ponderou, contudo, que em relação à atividade deste Ombudsman específico é correto afirmar que a sua forma de agir não se encaixa rigorosamente dentro do modelo de Ombudsman na Suécia, porquanto a lei não lhe conferiu as prerrogativas inerentes a um fiscal ou procurador judicial, não exercendo, por via de conseqüência, o papel de sujeito parcial da lide, em oposição ao que ocorre, por exemplo, com os Ombudsman parlamentares, para a liberdade econômica e para iguais oportunidades ${ }^{409}$.

Mesmo com todas as vantagens que o sistema de jurisdição coletiva pode oferecer no combate à discriminação no emprego, há que se ver com reservas a opinião de alguns autores que, conferindo interpretação demasiadamente ampliativa aos conceitos de interesses difusos, coletivos e individuais homogêneos, quase chegam a defender que em todas as hipóteses de discriminação seja possível o ajuizamento de ações civis públicas ${ }^{410}$.

Questão tormentosa acerca das ações que versam sobre discriminação nas relações de emprego é a referente ao ônus da prova. Como salienta Vera Lúcia Carlos, "adotando-se o regramento literal do art. 818, temos que é do trabalhador o ônus de provar a discriminação ocorrida, critério que na maioria dos casos não se mostra justa em razão do evidente desequilíbrio entre os litigantes"411. José Cláudio Monteiro de Brito Filho, propõe sobre o assunto, como medida, na

\footnotetext{
${ }^{407}$ SILVA NETO, Manoel Jorge. Proteção...op. cit., p. 80.

${ }^{408}$ Ibidem, p. 80.

${ }^{409}$ SILVA NETO, Manoel Jorge. Op. cit., p. 81.

410 Entendimento demasiadamente ampliativo é o defendido por Manoel Jorge Silva Neto na obra: SILVA NETO, Manoel Jorge. Op. cit., p. 172.
} 
solução jurisdicional, para permitir a proteção contra atos discriminatórios, a inversão do ônus da prova ${ }^{412}$.

A inversão do ônus da prova em todos as lides envolvendo alegações de discriminação, independentemente de o autor apresentar provas ou pelo menos indícios que corroborem suas assertivas, não parece, contudo, ser a melhor solução. Admiti-la implicaria obrigar o empregador a provar um fato negativo sempre que houver alegação deste gênero, o que nem sempre é possível e razoável. Melhor, portanto, aplicar a regra ordinária de distribuição do ônus da prova (arts. 818 da CLT e 333 do CPC), exigindo do demandante provas, ou pelo menos indícios, que demonstrarem a plausibilidade de suas assertivas. Exemplos destas seriam as disparidades estatísticas, um prima facie case, ou qualquer outra forma de indício. Nos casos em que a prova não estiver à disposição do autor, por estar de posse do réu, poderá ele requerer ao juiz a sua juntada sob pena de aplicação da sanção do artigo 355 do CPC. A hipótese não é de inversão do ônus da prova, como comumente vem sendo chamada, mas de prova de um fato constitutivo do direito do autor com documento juntado pelo réu, ou com a omissão deste em cumprir determinação neste sentido. O réu, por sua vez, poderá apresentar, se houver, uma razão legítima, não discriminatória para suas ações. Em seguida, se for o caso, possibilitar-se-á que o autor demonstre que essa justificativa era apenas um pretexto para mascarar um motivo ilegal, como sugerido no item $6.3 .3^{413}$.

\subsubsection{NEGOCIAÇÃO COLETIVA COMO INSTRUMENTO DE COMBATE À DISCRIMINAÇÃO.}

\footnotetext{
${ }^{411}$ CARLOS, Vera Lúcia. Op. cit., p. 62.

412 BRITO FILHO, José Cláudio Monteiro de. Op. cit., p. 85.

${ }^{413} \mathrm{Na}$ Itália, o ônus compete exclusivamente ao trabalhador que se considere discriminado. “A prova do objetivo ilícito perseguido pelo dador de trabalho só é fato irrelevante quando o ato discriminatório é objetivamente adequado para lesar o bem protegido, numa situação em que o onerado pode demonstrar também mediante simples presunções".SANTONI, Francesco. A tutela da dignidade e da privacidade do trabalhor. In: Princípios para um código-tipo de direito do trabalho para a América Latina. Gian Carlo Perone e Sandro Schipani (coords). São Paulo: LTr, 1996, p. 184.
} 
A Organização Internacional do Trabalho destaca também o importante papel da negociação coletiva como instrumento disponível aos sindicatos de trabalhadores e de empregadores para modificar de maneira concreta as condições e perspectivas de vida e trabalho das pessoas vulneráveis à discriminação. Em seu último estudo sobre a questão da igualdade nas relações de emprego, a OIT ponderou que, conquanto as cláusulas de fomento à igualdade sejam freqüentes nas convenções coletivas subscritas nos países industrializados, muito pouco se sabe sobre a eventual adoção deste tipo de cláusula nos países em desenvolvimento e nas economias em transição ${ }^{414}$.

Analisando especificamente a realidade brasileira, percebe-se que diversas Convenções Coletivas de Trabalho já contemplam cláusulas de vedação à discriminação. A Convenção Coletiva de Trabalho de 2005 (válida entre 01/03/05 e 28/02/06) firmada pelo Sindicato dos Transportes de Escolares da Região Metropolitana de Belo Horizonte - SINTESC e pelo Sindicato dos Trabalhadores em Transportes Rodoviários de Belo Horizonte vedava, em sua cláusula 16, qualquer tipo de discriminação contra portadores de deficiência no tocante a salários e critérios de admissão ${ }^{415}$. Na Convenção Coletiva firmada entre o Sindicato dos Administradores no Estado de Minas Gerais - SAEMG e o Sindicato da Indústria da Construção Civil no Estado de Minas Gerais - SINDUSCON MG, em 03/03/05, para vigorar entre 01/11/04 e 31/10/05, restou convencionado, em sua cláusula $13^{\text {a }}$, que a discriminação de sexos não poderá constituir motivo para critérios de diferença salarial e promoções ${ }^{416}$.

Vê-se, portanto, que o Brasil já vem evoluindo em matéria de utilização da negociação coletiva como instrumento de combate à discriminação.

\footnotetext{
${ }^{414}$ También la negociación colectiva es un medio fundamental que las organizaciones de trabajadores y de empleadores tienen a su alcance para cambiar de manera concreta las condiciones y perspectivas de vida y trabajo de las personas vulnerables a la discriminación.

Pese a existir una información abundante sobre la lucha contra la discriminación y a haberse incluido cláusulas de fomento de la igualdad en los convenios colectivos suscritos en los países industrializados, muy poco se sabe de la eventual adopción de este tipo de cláusulas en los países en desarrollo y las economías en transición. Es imprescindible colmar esta laguna de información a fin de determinar el mejor cauce de acción y velar así por que en la negociación colectiva se preste mayor atención a los problemas de discriminación en dichos países. (ORGANIZAÇÃO INTERNACIONAL DO TRABALHO (OIT). La igualdad...op. cit., p. 135).

${ }^{415}$ Disponível em: <http://sttrbh.br.tripod.com/Sintesc2005.htm>. Acesso em 25 de outubro de 2007.
} 
Além destas medidas, a Organização Internacional do Trabalho destaca ainda que as organizações de trabalhadores e de empregadores podem desenvolver iniciativas no próprio lugar de trabalho, elaborando isolada ou conjuntamente modelos de códigos de conduta ou diretrizes para fomentar a igualdade de oportunidades e de tratamento para todos ${ }^{417}$. Analisando a sugestão, sob a ótica do ordenamento jurídico brasileiro, a sugestão poderia ser posta em prática mediante a criação de códigos de conduta internos das empresas ou da vedação expressa de comportamentos discriminatórios nos regulamentos internos das empresas, com a cominação de sanções para as hipóteses de descumprimento, seja por iniciativa própria do empregador, seja mediante provocação da representação dos empregados na empresa ou do sindicato de empregados correspondente.

\subsubsection{AÇÕES AFIRMATIVAS}

Como observado em outro momento, as ações afirmativas (denominação derivada da expressão inglesa affirmative actions), também conhecidas como discriminações positivas (inspirada no termo francês discrimination positive) são a tônica do momento, em todo o mundo, no que se refere ao combate à discriminação e à promoção da igualdade ${ }^{418}$. Desta feita, nenhum trabalho que se dedique ao tema pode prescindir de um capítulo dedicado ao seu estudo.

\footnotetext{
416 Disponível em: <http://www.sinduscon-mg.org.br/ass_jur/ccts_2004/adm_04.pdf >. Acesso em: 25/10/07.

417 473. También las organizaciones de trabajadores y de empleadores pueden impulsar iniciativas en el lugar de trabajo, ya sea por separado o en el marco de la cooperación tripartita. El plan de acción de seguimiento recogerá información sobre estas experiencias, en particular sobre su alcance, contenido e impacto por sectores y por colectivos beneficiarios, y elaborará modelos de códigos de conducta o directrices para fomentar la igualdad de oportunidades y de trato para todos. Asimismo, se podría generar capacidades en algunos países donde ya se han emprendido iniciativas de este tipo y que deben consolidarse. (ORGANIZAÇÃO INTERNACIONAL DO TRABALHO (OIT). La igualdad...op.cit., p. $135)$.

${ }^{418}$ BOUCINHAS FILHO, Jorge Cavalcanti. Ações afirmativas e inserçãodas pessoas portadoras de deficiência no mercado de trabalho. In: Revista da Faculdade de Direito/Universidade de São Paulo, v. 100, 2005. São Paulo: Serviço Técnico de Imprensa da Faculdade de Direito da Universidade de São Paulo: 2005, p. 507.
} 
Como observa Flávia Piovesan, no âmbito do Direito Internacional dos Direitos Humanos, destacam-se duas estratégias de enfrentamento da problemática da discriminação: a estratégia repressivo-punitiva, que objetiva punir, proibir e eliminar a discriminação; e a estratégia promocional cujo escopo é promover, fomentar e avançar a igualdade ${ }^{419}$.

As ações afirmativas tanto podem partir de iniciativas estatais quanto de iniciativas privadas, objetivando sempre a efetivação da igualdade de oportunidades, a indução de transformações de ordem cultural, pedagógica e psicológica, aptas a subtrair do imaginário coletivo a idéia de supremacia e de subordinação de uma raça em relação à outra. $O$ elemento propulsor destas transformações seria o caráter de exemplaridade de que se revestem certas modalidades de ações afirmativas, a eliminação dos efeitos psicológicos, culturais e comportamentais da discriminação do passado, que tendem a se perpetuar, a implantação de uma certa "diversidade" e de uma maior "representatividade" dos grupos minoritários nos mais diversos domínios de atividade pública ou privada, a criação das chamadas personalidades emblemáticas, exemplos vivos de mobilidade social ascendente, que atuariam como mecanismos de incentivo à educação e ao aprimoramento de jovens integrantes de grupos minoritários, que invariavelmente assistem ao bloqueio de seu potencial de inventividade, de criação e de motivação a aprimoramento e ao crescimento individual ${ }^{420}$. O seu papel consiste em cumprir uma finalidade pública decisiva ao projeto democrático, que é a de assegurar a diversidade e a pluralidade social, constituindo-se, para tanto, em medidas concretas que viabilizem o

\footnotetext{
419 Em suas palavras: "Faz-se necessário combinar a proibição da discriminação com políticas compensatórias que acelerem a igualdade enquanto processo. Isto é, para assegurar a igualdade não basta apenas proibir a discriminação, mediante legislação repressiva. São essenciais as estratégias promocionais capazes de estimular a inserção e inclusão de grupos socialmente vulneráveis nos espaços sociais. Com efeito, a igualdade e a discriminação pairam sob o binômio inclusão-exclusão. Enquanto a igualdade pressupõe formas de inclusão social, a discriminação implica violenta exclusão e intolerância à diferença e à diversidade. $\mathrm{O}$ que se percebe é que a proibição da exclusão, em si mesma, não resulta automaticamente na inclusão. Logo, não é suficiente proibir a exclusão, quando o que se pretende é garantir a igualdade de fato, com a efetiva inclusão social de grupos que sofreram e sofrem um consistente padrão de violência e discriminação (PIOVESAN, Flávia. Discriminação. In: Fórum Internacional sobre Direitos Humanos e Direitos Sociais. São Paulo: LTr, 2004. p. 336).

${ }^{420}$ GOMES, Joaquim Benedito Barbosa. As ações afirmativas e o processo de implementação da igualdade efetiva. In: seminário internacional as minorias e o direito. Cadernos de CEJ n. 24, Centro de Estudos Judiciários, p 103-106.
} 
direito à igualdade, com a crença de que a igualdade deve se molar no respeito à diferença e à diversidade ${ }^{421}$.

Várias, contudo, são as críticas apresentadas às políticas de ação afirmativa. Uma das principais é a dificuldade de se caracterizar determinados grupos minoritários. Por exemplo, para fins de implemantação de ações afirmativas para combater a discriminação contra a mulher não há maiores dificuldades em identificar quem pertence a este grupo. $\mathrm{O}$ mesmo não pode ser dito em relação aos portadores de deficiência, sobretudo de deficiência mental, cuja identificação depende de um laudo médico apontando que determinado cidadão apresenta funcionamento intelectual significativamente inferior à média, com manifestação antes dos dezoito anos e limitações associadas a duas ou mais áreas de habilidades adaptativas, tais como comunicação, cuidado pessoal, habilidades sociais, utilização dos recursos da comunidade, saúde e segurança, habilidades acadêmicas, lazer e trabalho. Não obstante essa definição legal dada pelo art. 4 do Decreto n. 3.298 apresente grande precisão, ela não impede que a identificação dos portadores de deficiência caia no subjetivismo do elaborador do laudo pericial. Afinal, é perfeitamente possível que determinada limitação associada, por exemplo, à comunicação ou às habilidades acadêmicas, seja considerada uma deficiência por um perito médico e por outro não. Situação ainda mais complexa é a da identificação dos negros. Em um país marcado historicamente pela miscigenação de povos de várias origens, como é o caso do Brasil, definir quem deve ser considerado negro não é uma tarefa das mais fáceis.

Como salienta José Cláudio monteiro de Brito Filho, o certo, contudo, é que esses argumentos contrários às ações afirmativas não são suficientes para obstar medidas que são necessárias, pelo que, estabelecido esse pressuposto, basta que se defina como implementar as medidas, ficando superada a discussão sobre se é conveniente estabelecê-las ${ }^{422}$.

Esta conclusão se torna ainda mais irrefutável na medida em que estudos da própria Organização Internacional dão conta de que para

\footnotetext{
${ }^{421}$ PIOVESAN, Flávia. Discriminação. Op. cit, p. 337).

422 FERREIRA FILHO, Manoel Gonçalves. Direitos humanos fundamentais. $7^{\mathrm{a}}$ edição. São Paulo: Saraiva, 2005, p. 100.
} 
que os indivíduos possam superar a situação de pobreza é necessário promover medidas de ação positiva para promover um ambiente geral favorável à igualdade de oportunidades e de tratamento no trabalho entre homens e mulheres, negros e brancos, num marco cujos princípios estão estabelecidos nas convenções da OIT sobre a discriminação no emprego e na ocupação (Convenção no 111, de 1958), e sobre

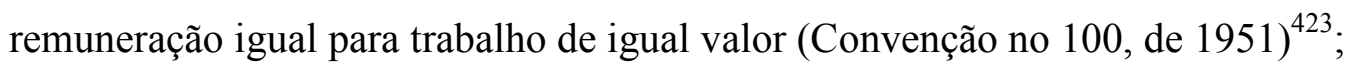

A este respeito, bastante interessante mostra-se a Convenção Coletiva de Trabalho firmada pelo Sindicato dos Empregados em Estabelecimentos de Serviços de Saúde de São Paulo e o Sindicato dos Hospitais, Clínicas, Casas de Saúde, Laboratórios de Pesquisas Análises Clínicas do Estado de São Paulo, firmada com o objetivo precípuo de criar um programa de inclusão de pessoas com deficiência ${ }^{424}$. Referido instrumento, firmado em 16 de maio de 2006 para vigorar desta data até o dia 15/04/08, apresenta dezessete cláusulas e inclui entre os seus considerandos o fato de o Programa de Ação Interinstitucional da DRT/SP, criado pela Portaria GD/DRT/SP n ${ }^{0}$ 700, de 10.09.04, haver estabelecido como uma das prioridades para o estado de São Paulo a inserção das pessoas com deficiência no mercado de trabalho. Trata-se, em verdade, de um instrumento normativo que busca dar efetividade a uma das hipóteses de ação afirmativa consagradas na legislação brasileira, bem como às políticas institucionais desenvolvidas em decorrência dela. $\mathrm{O}$ principal ponto positivo a ser destacado na mencionada convenção é o fato de sindicatos operário e patronal haverem se mobilizado para criar instrumento visando o preenchimento das quotas legais de deficiente por empresa. Como aspecto negativo há que se destacar que a cláusula $2^{\mathrm{a}}$ torna facultativa a adesão das empresas representadas pelo Sindicato aos termos da presente Convenção Coletiva de Trabalho, o que reduz substancialmente a sua eficácia e validade ${ }^{425}$.

\footnotetext{
${ }^{423}$ ORGANIZAÇÃO INTERNACIONAL DO TRABALHO (OIT). Manual.... v.1 p. 114.

${ }^{424}$ Disponível em $<$ http://www.sindhosp.com.br/IMP_275e.html>. Acesso em 25/10/07.

${ }^{425}$ CLÁUSULA 2 - DA ADESÃO PELAS EMPRESĀS

Será facultado às empresas representadas pelo Sindicato patronal a adesão aos termos da presente Convenção Coletiva de Trabalho, sem prejuízo do dever de adotar todas as medidas necessárias ao cumprimento de suas cotas, nos termos da lei, dando prosseguimento ao processo de seleção já em andamento, objetivando atender o comando legal relativo ao cumprimento de suas cotas, independentemente das ações adotadas pelos Sindicatos signatários. Disponível em $<$ http://www.sindhosp.com.br/IMP_275e.html $>$. Acesso em 25/10/07.
} 


\section{DISCRIMINAÇÃO POR SOBREQUALIFICAÇÃO.}

Como muito bem observado pelo Procurador Manoel Jorge e Silva Neto, a discriminação no emprego tem despertado preocupações "não somente pela habitualidade com que se defronta com as práticas discriminatórias, mas também pela diversidade das espécies de discriminação ocorrentes nos domínios da relação de trabalho" 426 .

Além das discriminações em razão da raça, origem, sexo, cor, aptidão física e idade, percebidas desde tempos imemoriais e que vêm sendo progressivamente combatidas, novas formas de discriminação sã verificadas e merecem igual atenção dos operadores do direito ${ }^{427}$. Sobretudo em um ordenamento jurídico como o brasileiro, onde se combate qualquer forma de discriminação. É o que leciona Paulo Jakutis:

No caso do Brasil, por força expressa do art. $3^{\circ}$ da Constituição Federal (“... e quaisquer outras formas de discriminação"), combinado com a Convenção n.111 da OIT

\footnotetext{
${ }^{426}$ SILVA NETO, Manoel Jorge e. Direitos fundamentais e contrato de trabalho. São Paulo: LTr, 2005, p. 169. O informe global con arreglo al seguimiento de la Declaración de la OIT relativa a los princípios e derecho fundamentales relativos al trabajo, I da 96 Reunião Anual da Organização do Trabalho (OIT), realizada em 2007, o aparecimento de novas formas de discriminação e a maneira como elas acentuam o problema da recompilação de dados relativos à práticas discriminatórias: "La aparición de nuevas formas de discriminación, que se suman a aquellas ya arraigadas, como las que se basan en el género, la raza, y la religión, acentúan el problema de la recopilación de datos. Existe una sensibilización creciente al trato injusto que sufren los jóvenes, las personas de más edad, las personas con discapacidad y aquellas infectadas por el VIH/SIDA. A ello se añade la aparición de prácticas que penalizan a las personas con una predisposición genética a padecer de ciertas enfermedades o que tienen ábitos considerados como poco saludables. Casi todos los modos de vida tienen alguna incidencia en la salud, luego de lo que se trata es de trazar la línea divisoria entre lo que un empleador puede regular y la libertad de cada empleado de llevar la vida que estime conveniente". (ORGANIZAÇÃO INTERNACIONAL DO TRABALHO (OIT). La igualdad..., p;10).

427 O último informe global da Organização Internacional do Trabalho dedica um capítulo às formas de discriminação recém reconhecidas, incluindo entre elas a discriminação contra trabalhadores jóvens, contra trabalhadores de mais idade e em decorrência da orientação sexual ou de deficiência. (Ibidem, pp. 42/52). O mesmo documento dedica também um capítulo ao estudo de manifestações incipientes de discriminação entre as quais se inclui a discriminação baseada em fatores genéticos e em estilo de vida (Ibidem, pp. 53/54).
} 
(“...que tenha por efeito destruir ou alterar a igualdade de oportunidade ou de tratamento em matéria de emprego ou profissão..."), qualquer forma de distinção, que implique em destruição ou alteração da igualdade de tratamento (em outras palavras, que implique em qualquer prejuízo para o trabalhador), deverá ser considerada como conduta discriminatória, na área do trabalho, não havendo a necessidade de se buscar um grupo protegido para fazer ligação da característica ou conduta que gerou a distinção com ele. Em outras palavras, as características protegidas expressamente pelo art. $3^{\circ}$ da Constituição (origem, raça, sexo, cor e idade) e pelos tratados de convenções internacionais ratificados pelo Brasil, em matéria trabalhista, devem ser considerados como meramente exemplificativas ${ }^{428}$.

No mesmo sentido são os ensinamentos de Estêvão Mallet, segundo quem o artigo $7^{\circ}$, inciso XXX, da Constituição traça apenas parâmetros exemplificativos, podendo-se claramente se inferir que o sistema constitucional brasileiro proíbe genericamente qualquer forma de discriminação ${ }^{429}$.

Francisco Gérson Marques de Lima destaca o corriqueirimismo das discriminações observando que desde a criação dos tempos, o ser humano procura estabelecer diferenças em tudo; encontrando, em todos os setores onde atua, uma maneira de impor distinções e criar critérios de preferências e privilégios de uns em detrimento de outros. Para ele haveria apenas variações nas diferenciações, estabelecidas de acordo com a sociedade, a cultura do povo, a época, o local e os valores por ela eleitos, e segundo determinadas circunstâncias, mas somente àquelas sem razão lógica alguma, de índole meramente subjetiva e sem nenhuma relação ou pertinência com o objeto do que se lhe apresenta, seriam vedadas pelo ordenamento ${ }^{430}$.

\footnotetext{
${ }^{428}$ JAKUTIS, Paulo. Op. cit., p. 148.

${ }^{429}$ MALLET, Estêvão. Op. cit., p. 355.

${ }^{430}$ Em suas palavras: "Em uma sociedade rudimentar, onde a força bruta seja constantemente empregada, supervalorizam-se as pessoas robustas, musculosas e dotas de elevada estatura e coragem. Nas sociedades mais avançadas, onde os valores sejam a criatividade, a ciência e o intelectualismo, dá-se maior crédito às pessoas cultas, dotadas de conhecimentos mais abrangentes e conhecedoras dos problemas do espírito humano". E assevera ainda o autor citado: "o homem, dentro de um espírito por vezes maléfico e involuído, tem criado modalidades de distinções sem razão lógica alguma. Discriminações de índole meramente subjetiva e sem nenhuma relação ou pertinência com o objeto do que se lhe apresenta. Estas distinções, sim, são vedadas pelo ordenamento”. LIMA, Francisco Gérson Marques de. Op. cit., pp. 40/41.
} 
José Cláudio Monteiro de Brito Filho, destaca que dois grupos aparentam sofrer os efeitos da falta de ocupação mais que os outros: os trabalhadores sem qualificação, pois o mercado, por força da implantação de novas tecnologias na produção, cada vez menos exige sua presença; e os que, por diversas razões, pertencem a grupos que são alijados do processo produtivo ${ }^{431}$. Destacando que a lógica do mercado atual impõe ao empregado o dever de se qualificar sob pena de restar sem empregabilidade, Leonardo Vieira Wandelli assim se pronunciou:

Ao invés de se falar de um direito ao trabalho, como plataforma de efetivação da cidadania e de livre desenvolvimento da personalidade pelo trabalho, previsto na Constituição, tanto do ponto de vista do titular (art. $6^{\circ}$ ), quando do ponto de vista da obrigação das políticas públicas e da ordem econômica, que devem promover o pleno emprego (art. 170), invertem-se as posições. É responsabilidade do trabalhador investir em sua formação e manter-se suficientemente qualificada para os postos de trabalho oferecidos pelo mercado. Deste, porém, nada pode ser exigido, pois se trata de um espaço regido apenas pela busca do lucro. Somente ao trabalhador pode ser imputado o próprio desemprego e a ele cabe fazer tudo para superar essa situação, estando disponível, em condições, para que, ao alvitre do mercado, seja "escolhido" 432 .

Há que se destacar, contudo, que o investimento em qualificação profissional, embora continue necessário, já não basta para garantir empregabilidade ${ }^{433}$. Há casos até em que ela vem sendo utilizada como fator de discriminação. Com efeito, a chamada pós-modernidade, caracterizada eminentemente pela busca incessante pelo lucro e pela excessiva competitividade, vem testemunhando o surgimento, ou quiçá o aumento, da freqüência e ocorrência de uma nova forma de discriminação que subverte um pouco a antiga lógica de que o desemprego era maior entre os trabalhadores menos qualificados. O que, como visto, não implica ausência de proteção contra ela. Os empregados sobrequalificados, aqueles que têm formação

\footnotetext{
${ }^{431}$ BRITO FILHO, José Cláudio Monteiro de. Op. cit., p. 15.

${ }^{432}$ WANDELLI, Leonardo Vieira. Despedida abusiva. O direito do trabalho em busca de uma nova racionalidade. São Paulo: LTr, 2007, p. 86.

${ }^{433}$ É o que evidenciam as palavras de René Dumont e Charlotte Paquet, relacionadas ao sistema francês, mas cujas conclusões aplicam-se em uma perspectiva global: "Enquanto o desemprego atingia os pobres, as pessoas pouco qualificadas, isso era atribuído à insuficiência da formação; e projectava-se - a justo título - aumentar a aprendizagem, como na Alemanha. Hoje em dia, o mal atinge os quadros e os filhos da alta burguesia, dos meios cultos, dotados dos melhores diplomas, e saídos até das grandes escolas, a fina-flor do sistema educativo francês: já nem todos estão seguros de conseguir um emprego"
} 
superior à complexidade das tarefas que realizam, ao invés de serem valorizados por este fato, passam a ser preteridos justamente em razão dele. Em outras palavras, o acúmulo de conhecimentos e a melhor formação profissional, passam a ser justamente o motivo do discrimen.

Esta nova forma de conduta diferenciadora foge um pouco à regra de que a discriminação decorre de preconceitos, frutos, em geral, de estereótipos socialmente criados. Em regra não há preconceito contra as vítimas de discriminação por sobrequalificação, nem são elas estereotipadas. Conquanto em alguns casos possa haver uma preterição em razão do receio de que o empregado sobrequalificado sinta-se desmotivado para o trabalho, na maioria das hipóteses analisadas e vislumbradas, o empregador não as pretere, por ocasião da contratação ou de alguma promoção, nem as escolhe para a dispensa por terem preconceito contra elas. Os seus motivos, como oportunamente se verá, são outros. Ele não as repudia ou rejeita porque são muito qualificadas. Simplesmente não as quer consigo por essa razão.

A ausência de preconceito e de estereotipização, antes de tornar a discriminação por sobrequalificação menos nociva, torna-a ainda mais censurável. O preconceito, embora não possa ser justificado, pode ser explicado pelos aspectos histórico-culturais do local onde se desenvolveu o agressor. O fato, por exemplo, de haver crescido em uma região onde houve durante anos a exploração de escravos negros, embora não justifique, explica, em muitas regiões, a rejeição dos seus descendentes pelos descendentes de seus senhores. São fatores que, embora internos, subjetivos do agressor, remontam a questões históricas sobre as quais ele não teve qualquer ingerência. No caso da discriminação por sobrequalificação, quando ausente o preconceito, a razão para a sua existência é a ganância ou o temor do empregador.

Essa forma de discriminação seguramente é uma das razões para o chamado desemprego de colarinho-branco, realidade para a qual Barbara Ehrenreich chamou atenção em seu best-seller. A jornalista americana utilizou essa expressão para designar os desempregados com alta-qualificação, em contraponto à 
expressão colarinhos-azuis, com a qual se refere à mão de obra pouco qualificada. Para escrever sua obra ela se passou por desempregada de colarinho-branco, e após vivenciar diretamente o tormento em que consiste a busca de emprego por pessoas qualificadas, destacou:

As histórias sobre a mobilidade descendente dos colarinhos-
brancos não podem ser postas de lado com tanta facilidade
quanto os relatos das atribuições econômicas dos colarinhos-
azuis que os impiedosos atribuem às "más-escolhas": não
obter um diploma universitário, por exemplo, não adiar a
gravidez até fazer um pé-de-meia ou, antes de qualquer
coisa, não ter escolhido pais ricos. Mas os angustiados
colarinhos-brancos não podem ser acusados de qualquer tipo
de fraqueza; eles são os que fizeram tudo "certinho".
Conquistaram os títulos universitários mais altos, quando
sempre pondo de lado a paixão da juventude pela filosofia
ou pela música para aturar profissões práticas maçantes
como administração ou finanças. Em alguns casos,
progrediram tanto que, exatamente por terem atingido
cargos tão elevados nas empresas, seus salários passaram a
ser vistos como um tentador corte de custos ${ }^{434}$.

Os exemplos de discriminação dessa natureza são incontáveis e podem ser identificados tanto na fase de formação do contrato de trabalho, chamada pré-contratual, durante a vigência deste ou mesmo no momento de sua ruptura.

Incontáveis também são os malefícios que ela pode acarretar. Socialmente ela tende, com o passar do tempo, a inverter a concepção de que qualificação profissional é fator de empregabilidade, o que certamente desestimularia a procura por capacitação e educação para combater o desemprego. E isto, em um país onde falta mão-de-obra qualificada em diversos setores, poderia ser absolutamente desastroso. Pessoalmente essa forma de discriminação causa grande desamparo na vítima. Se uma das alternativas encontrada pelos desempregados para sair desta situação é o investimento em qualificação profissional, aquele que percebe estar sendo alijado do mercado de trabalho justamente em razão de sua formação se sente sem esperanças por não poder buscar esse caminho. 


\subsection{DISCRIMINAÇÃO POR SOBREQUALIFICAÇÃO NA FORMAÇÃO DO CONTRATO DE TRABALHO.}

Exemplo de discriminação por sobrequalificação no momento da formação do contrato verifica-se quando o responsável pelo recrutamento de pessoal pretere um ou mais dos candidatos não pelo seu desempenho durante o processo seletivo ou entrevista, mas simplesmente porque ele apresenta uma formação profissional e qualidade superior à necessária para o desempenho da função vaga. Seria uma hipótese típica de tratamento diferenciado, estudado no item 6.3, uma vez que o empregador estaria tratando uma pessoa menos favoravelmente do que outras em razão de uma condição pessoal que não constituiria óbice para o exercício da atividade profissional. Pode acontecer de o motivo da discriminação ser flagrante, bem como dele ser inferido a partir de diversos outros fatores.

Durante a elaboração deste trabalho, entrevistou-se um economista, cujo nome permanecerá em sigilo ${ }^{435}$, que relatou hipótese clara de discriminação por sobrequalificação. $\mathrm{O}$ entrevistado declarou ter trabalhado como bancário, salientando que após ser desligado passou a ter dificuldades de encontrar recolocação no mercado de trabalho por ser qualificado demais para os postos de trabalho pleiteados. Durante os dez anos que passou desempregado enviou currículos para várias outras empresas, inclusive outros bancos, mas jamais passava do momento da entrevista no processo seletivo. Tentou, sem sucesso, montar uma empresa com dois amigos do curso de graduação, mas desistiu da empreitada porque ela não cobria sequer as despesas. Procurou empregos que não exigiam nível superior por compreender que na região em que reside (Região metropolitana da cidade do Natal$\mathrm{RN}$ ) não há muitos postos de trabalho para economistas e por não desejar ficar parado. Em situações como esta uma conduta discriminatória pautada na sobrequalificação do

${ }^{434}$ EHREINREICH, Barbara. Desemprego de colarinho branco. (trad.) Ana Maria Mandim. Rio de Janeiro: Record, 2006, p. 8.

${ }^{435}$ integra da entrevista em anexo. 
empregado implica clara negação de seu direito ao trabalho uma vez que na ausência de trabalhos próprios de sua formação qualificação profissional o trabalhador somente tem duas opções. Ou aceita trabalhar em função que não demande o uso de seus conhecimentos superiores, ou fica desempregado.

Em um dos trechos mais interessantes de seu relato, o entrevistado contou que inicialmente colocava em seu currículo que era graduado e asseverou que em alguns casos nem era chamado para seleção, e em outros ouviu o entrevistador exclamar "aaa vc é formado em economia né?". O entrevistado relatou ainda que algumas vezes o entrevistador afirmou expressamente que ele era qualificado demais para o posto ou lhe perguntou por que alguém com tanta qualificação desejava um emprego que não demandava formação de nível superior. Como nestas situações acabou não sendo contratado, são fortes os indícios de que sua titulação acadêmica fora o óbice para o seu recrutamento.

Estes indícios são corroborados pela observação do entrevistado de que nas várias vezes em que fora contratado omitira o fato de ter nível superior, falar língua estrangeira e ter conhecimento maior que o básico de informática.

É evidente que não se poderia simplesmente obrigar as empresas das quais ele participou do processo seletivo a contratá-lo por ser formado em economia, qualificação, aliás, que em nada o tornava mais habilitado para exercer as funções às quais se candidatou (escriturário, auxiliar administrativo, tradutor, prestador de serviços de informática, ou corretor de imóveis). Inadmissível, contudo, é que o empregador descarte preliminarmente a possibilidade de fazê-lo, não o permitindo sequer iniciar o processo seletivo, simplesmente porque ele é graduado. Afinal, sempre há a possibilidade de alguém que estudou para desempenhar outras funções se mostrar um habilidoso vendedor de imóveis, auxiliar administrativo, tradutor ou prestador de serviços. A sua sobrequalificação há que ser encarada como uma vantagem, como um algo mais, nunca como um fator de discriminação. Trata-se de um diferencial que, se não ajudar, certamente não atrapalhará. E como salienta Francisco Gérson Marques de Lima: 
Se de um lado, o empregador (ou ex-empregador) tem o direito e a faculdade de admitir aquele que mais lhe pareça adequado ao trabalho, bem ainda o de prestar informações sobre quem laborou para si, não pode, de outro lado, em nome dessa faculdade, utilizar-se da prerrogativa para praticar atos discriminatórios ${ }^{436}$.

Ao ser questionado por que razão passara a não mais mencionar o fato de ser graduado, o entrevistado respondeu ter ouvido de amigos que seria melhor não informar que tinha alguma graduação para não assustar o empregador, "pois geralmente pessoas graduadas ou com um pouco mais de informação são funcionários que reclamam mais direitos que os que têm menos informação". Esta declaração, conquanto imprecisa e indeterminada quanto a sua fonte, fornece um dado relevante. A partir dela pode-se concluir pela possibilidade de hipóteses de discriminação como a do economista entrevistado serem causadas pelo receio de que a contratação de empregados mais qualificados do que o necessário resulte em uma maior probabilidade de reclamação trabalhista no futuro. Receio que, embora justifique a conduta adota, explica-se em parte pelo fato de empregados mais esclarecidos conhecerem mais profundamente seus direitos e possuírem melhores condições de reivindicá-los.

Outro exemplo claro de discriminação por sobrequalificação no ato da contratação foi o vivenciado por um professor de história entrevistado durante a elaboração deste trabalho (entrevista no anexo II). Após haver se graduado em história no ano de 1994, e concluído mestrado em 1997, ingressou no magistério superior, mediante seleção pública, no cargo de professor substituto em uma Universidade Federal. Como previsto em seu contrato temporário, firmado nos termos da Lei n.8745/93, o entrevistado foi desligado quando atingido o termo previamente estabelecido. Passou então a procurar emprego em faculdades particulares e também em escolas, uma vez que precisava trabalhar e não podia esperar o interesse de uma instituição de ensino superior. Nestas últimas fez entrevistas cujo resultado foi descrito como frustrante. $\mathrm{O}$ entrevistado constatou que aquilo que imaginara que seria seu diferencial, a sua titulação como mestre e sua experiência de mais de dois anos no ensino superior, mostrou-se, ao contrário, o principal obstáculo para a sua contratação. Após asseverar expressamente ter se sentido discriminado em razão de sua qualificação

${ }^{436}$ LIMA, Francisco Gérson Marques de. Op. cit., p. 31. 
em razão de o fato de possuir mestrado haver dificultado seu acesso a entrevistas e processos de seleção em escolas do ensino médio, o entrevistado fez o seguinte relato:

Disseram-me, por duas vezes, que o meu currículo estava além do necessitado pelas escolas, que o meu grau de intelectualidade poderia ficar acima da compreensão dos alunos.

A justificativa para a exclusão do candidato não poderia ser mais censurável. O fato de o currículo do candidato estar além do necessitado pelas escolas não poderia jamais justificar a sua eliminação sumária do processo seletivo. A uma porque isto não é indicativo de que suas aulas sejam acima da compreensão dos alunos. Afinal, um professor bem titulado tem condição de adaptar suas aulas às necessidades da platéia que as assistirá. A duas, porque o próprio sistema educacional brasileiro vem se organizando no sentido de incentivar que mesmo os profissionais do ensino básico cursem programas de pós-graduação. É o que se depreende da seguinte passagem:

Em 2007, a CAPES foi lançada a um novo desafio: passar a colocar em prática a sua extraordinária experiência na pósgraduação também na formação de professores do ensino básico, tendo como alvo a busca permanente da qualidade neste nível educacional. As metas ambiciosas do Plano Nacional de Educação (PDE) e a prioridade que o governo brasileiro vem dando à melhoria da Educação Básica compelem a CAPES a missão de ingressar de forma ampla nesse segmento. Hoje, a ampliação da oferta, a melhoria das condições de ensino e a adequação da formação do educador, bem como mecanismos para atrair e manter na carreira profissionais qualificados são os principais requisitos para a universalização da oferta de todas as etapas da Educação Básica, com qualidade ${ }^{437}$.

Conquanto a discriminação seja direta na medida em que o entrevistador deixou transparecer expressamente que a opção pela não contratação do entrevistado decorria do fato dele ser mais qualificado do que o necessário para a função, não há como se inferir qual o real motivo da preterição do candidato. Não há como se aferir se o entrevistador realmente entendia que alguém

${ }^{437}$ FUNDAÇÃO NACIONAL DE DESENVOLVIMENTO DO ENSINO SUPERIOR PARTICULAR (FUNDANESP). Legislação e Normas da Pós-Graduação Brasileira. $3^{\mathrm{a}}$ edição. Brasília: FUNDANESP, 2007, p. 15. 
com experiência no ensino superior seria inadequado ao ensino médio, o que não retira a ilicitude de sua conduta, ou se esta assertiva escondia algum motivo obscuro como, por exemplo, o temor de que o novo contratado, por sua maior qualificação, passasse, com o tempo, a exercer as suas funções. Insegurança e temor de perda da ocupação são alguns dos verdadeiros motivos para se preterir um candidato mais qualificado.

Uma terceira situação de possível discriminação por sobrequalificação foi a vivenciada pelo advogado entrevistado. Em seu relato, ao ser questionado, ele destacou entender que a sua formação acadêmica (titulação de mestre) tanto o ajudou quanto o atrapalhou em uma seleção de emprego. Em suas palavras:

Facilitou porque a primeira entrevista foi feita com uma pessoa que valorizava a formação acadêmica. Dificultou porque a segunda entrevistadora entendeu que eu poderia me desestimular com o trabalho porque vinha de uma formação acadêmica superior ${ }^{438}$

Ele justificou sua suspeita asseverando que a segunda entrevistadora, que seria sua superiora imediata, questionou-lhe se depois de ter feito mestrado, ele não acharia o trabalho na empresa uma atividade repetitiva e desestimulante. Ao responder as perguntas seguintes, o entrevistado deixou claro ainda que a segunda entrevistadora, embora aparentasse ter sua mesma idade, ainda estava fazendo especialização o que poderia ter feito com que ela se sentisse ameaçada com receio de não conseguir impor sua autoridade por meio de seu conhecimento. Questionado, o advogado asseverou ainda achar possível que ela tenha lhe preterido por receio de perder o cargo.

É certo que não se pode chegar a uma conclusão definitiva acerca de haver se tratado ou não de uma conduta discriminatória com base única e exclusivamente no depoimento da vítima, permeado de subjetividade e talvez de mágoas. Os indícios, porém, de que ele tenha sido excluído por ser mais qualificado do que a entrevistadora, que viria a ser sua superiora, caso ele tivesse sido contratado, são muitos. Primeiramente há que se destacar o fato de ambos possuírem aparentemente a mesma idade e o entrevistado possuir formação acadêmica superior, já tendo concluído curso de mestrado enquanto a entrevistadora apenas cursava 
especialização. Em segundo lugar, porque o comentário da entrevistadora que levou o entrevistado a concluir que a sua não escolha se deveu à sua maior formação acadêmica não pode justificar uma preterição no emprego. Duas são as razões. A primeira, porque não parece razoável concluir que o entrevistado achasse o trabalho no departamento jurídico de uma empresa repetitivo e desestimulante somente por haver concluído um curso de mestrado. Sobretudo, porque no caso em questão a análise curricular que precedeu as entrevistas evidenciou que ele já desempenhara esta função em outra empresa, o que demonstra que este tipo de atividade não lhe desagrada. Até porque não deixou a empresa anterior porque quis, mas por razões de reformulação da política interna. Em segundo lugar, caberia ao entrevistado concluir, depois de iniciadas as atividades, se o trabalho é ou não enfadonho para alguém com sua titulação. Preterir alguém com experiência e boa formação acadêmica com base em meras suposições de que ele possa a se sentir desinteressado e desestimulado é inconcebível. Ao fazê-lo, a entrevistadora desmereceu sua própria atividade e ainda excluiu do processo seletivo um profissional qualificado que possivelmente poderia vir a ser um ótimo empregado.

Diante de tudo o que foi estudado até o presente momento, é possível afirmar que a exclusão de candidatos de um processo seletivo aberto simplesmente por possuírem titulação superior à necessária para o exercício da função para a qual se candidatou consiste em odiosa forma de discriminação, que viola ainda o direito ao desenvolvimento subjetivo dos candidatos preteridos e o interesse público em fomentar uma educação que qualifique para o trabalho estabelecido no artigo 225 da Constituição Federal. Afinal, se o cidadão possui direito à educação para se qualificar para o trabalho, negar-lhe um emprego porque ele se qualificou é adotar uma conduta absolutamente incompatível com o que idealizou o legislador constituinte.

Como salienta Bernard Raymond Guimbo, a necessidade de desenvolvimento é consubstancial ao homem, estando o seu direito a ele necessariamente ligado ao seu destino e ao da humanidade, na medida em que sua ausência o distancia do ideal universalista. Em sua opinião, o desenvolvimento é algo complexo, que parte da pessoa e se alarga a uma dimensão social. Por ser ele consubstancial ao ser humano, consiste em um verdadeiro direito do homem, sem o

\footnotetext{
${ }^{438}$ Íntegra da entrevista em anexo.
} 
qual a dignidade da pessoa humana não passa de uma quimera. E finaliza asseverando que nós não temos o direito de colocar freios ao desenvolvimento individual, porque ele permite humanizar o mundo e realizar progressivamente, dentro da justiça, os aspectos da plenitude do homem ${ }^{439}$.

Cumpre ressaltar que embora não se possa impor ao empregador que contrate alguém com formação superior à necessária, o que consistiria censurável violação à sua liberdade, também não se pode admitir que ele exclua alguém do processo seletivo simplesmente porque ele a tem, mas está disposto, por opção ou por necessidade, a exercer uma função que não a requeira e a receber, a título de remuneração, o que os demais colegas sem a mesma formação possuírem.

O problema cuja reflexão ora é proposta não é saber se é possível impor ao empregador a contratação de quem tiver mais formação acadêmica. Longe disso. Reconhece-se que o empregador, dentro de seu poder diretivo é livre para contratar quem ele entender que desempenhara o trabalho da melhor maneira, ou simplesmente de uma maneira satisfatória que é o que ele efetivamente necessita. A questão é impedir que determinados candidatos sejam excluídos previamente da disputa pelo simples fato de serem mais qualificados do que o necessário. Em especial, em um momento em que o desemprego adquiriu tamanha proporção que já não há mais postos de trabalho qualificado para todos e, por conseguinte, a busca por ocupações com exigência de aptidões menores do que as que se possui aparece muito mais como uma necessidade do que como uma opção. É o que destaca Barbara Ehrenreinch no seguinte trecho de sua obra:

PARA AQUELES QUE não podem se dar ao luxo de ser exigente quanto a status ou salário, há, naturalmente,muitos empregos nos Estados Unidos. Centenas de milhares de

\footnotetext{
${ }^{439}$ En somme, le besoin de développement est consubstantiel à l'homme. Le droit au développement est nécessairement lié à la destinée de l'homme et au destin de l'humanité et l'absence du développement éloigne de l'ideal universaliste.(...) Le développement dont il s'agisse est complexe, il part de la personne et s'elargit à la dimension sociale. Parce qu'il est consubstantiel à l'être humain, il est un véritable droit de l'homme, sans lequel l'égale dignité de la personne humaine n'est que chimère. On n'a pas le droit d'y mettre des freins, car il permet d'humaniser le monde et de réaliser progressivement, dans la justice, les aspects de la plénitude de l'homme. (GUIMBO, Bernard Raymond. Op. cit., pp.78/79)
} 
imigrantes entram no país todos os anos para trabalhar na conservação de jardins, na construção civil, ou como faxineiras, babás e embaladores de carne. Mesmo sem a criação de novos empregos, a grande rotatividade do setor de empregos de baixos salários garante uma oferta firme de oportunidades para os que precisam de trabalho temporário e os desesperados. Para os colarinhos-brancos que procuram emprego, são conhecidos como "empregos de sobrevivência" - alguma coisa para fazer enquanto se espera o aparecimento do "verdadeiro" trabalho. Mas esta designação pode ser otimista demais ${ }^{440}$.

Ora, se nos Estados Unidos, país altamente industrializado e detentor de uma das mais sólidas economias do mundo, muitos empregados se submetem a aceitar postos de trabalho que não requerem toda a sua qualificação para garantir o sustento de suas famílias, o que se dirá da realidade no Brasil, país ainda em desenvolvimento. Seria razoável impedir que os empregados qualificados tenham acesso aos postos de trabalho não qualificados disponíveis, simplesmente por terem buscado maior qualificação? Terão eles que aguardar que sejam criados postos compatíveis com sua alta formação, pois o trabalho menos qualificado lhes é negado? E se estes nunca vierem a ser criados em número suficiente? Como preservar seu direito ao trabalho, constitucionalmente assegurado?

É bem verdade que a sobrequalificação ainda é muito associada à insatisfação e desmotivação profissional. Ainda predomina a idéia de que o empregado sobrequalificado é um empregado frustrado por não estar desenvolvendo todo o seu potencial. Segundo o resumo da análise dos resultados do Segundo Inquérito Europeu sobre as Condições de Trabalho, levado a cabo em 1996 pela Fundação Européia para as Condições de Vida e de Trabalho, "Sentir-se sobrequalificado ou subqualificado relativamente ao conteúdo do posto de trabalho, significa que não se está satisfeito com o emprego"441.

É preciso, contudo, analisar a questão sob o ponto de vista do mundo em transformação, no qual se vem constatando que a criação de postos de trabalho qualificados para pessoas com formação de nível superior não tem

\footnotetext{
440 EHREINREICH, Barbara. Desemprego de colarinho branco. (trad.) Ana Maria Mandim. Rio de Janeiro: Record, 2006, p. 215.

${ }^{441}$ Disponível em <www.eurofound.europa.eu/pubdocs/1997/42/pt/1/ef9742pt.pdf> . Acesso em 25 de outubro de 2007.
} 
acompanhado o aumento no nível de escolarização. E como salienta Antônio Rodrigues de Freitas Júnior, em um mundo de induvidoso declínio das oportunidades de ocupação remunerada, é preciso reconstruir identidades e revisitar as premissas pelas quais fomos obrigados a conferir parâmetros de dignidade à condição humana ${ }^{442}$.

Concluir, portanto, que empregado sobrequalificado é sinônimo de empregado insatisfeito, em um mundo onde muitos são obrigados a ocupar postos de qualificação inferior à sua formação por falta de opção, não deixa de ser uma forma de preconceito capaz de ensejar condutas discriminatórias ${ }^{443}$.

O número de postos de trabalho vem declinando acentuadamente em decorrência de fenômenos como a globalização e os avanços tecnológicos nas áreas de informática e de robótica e os novos que vêm surgindo, em sua maioria estão relacionados com atividades não qualificadas. Segundo Jeremy Rifkin, "embora alguns novos empregos estejam sendo criados na economia americana, estão em faixas de remuneração inferiores e, geralmente, são empregos temporários”. Para ilustrar suas assertivas, o autor destaca que em abril de 1994, dois terços dos novos empregos criados no país estavam na faixa inferior da pirâmide de remuneração e que no primeiro trimestre de 1994, segundo dados da empresa de recolocação Chalanger, Gray Christmas, as demissões das grandes corporações eram 13\% superiores às de 1993, havendo a previsão dos analistas do setor de que cortes ainda maiores viriam nos meses e anos subseqüentes. E mais. $\mathrm{O}$ autor destaca que a perda de

\footnotetext{
${ }^{442}$ FREITAS JÚNIOR, Antônio Rodrigues de. Op. cit., p. 156.

${ }^{443}$ Interessante a este respeito é a reflexão proposta em artigo veículado na revista Superinteressante de novembro de 2007, no qual Pedro Burgos, tece as seguintes considerações a partir de entrevista feita com a professora inglesa Alison Wolf: "Século 21, Era do conhecimento. Nunca a educação foi tão importante para as pessoas. Quem não tiver qualificação dificilmente terá oportunidades no mercado de trabalho. Corra para a universidade. O discurso faz sentido: está por trás das políticas públicas que influenciaram a explosiva expansão do ensino superior no Brasil e no mundo nos últimos 15 anos. Só faltou combinar com o mercado...Na vida real, as profissões de nível universitário não cresceram o suficiente para sustentar a multidão que tomou de assalto o banco das faculdades. O telemarketing, por outro lado, cresceu. Como cresceram outros empregos que exigem pouca especialização. Não dão tanto dinheiro, mas são uma opção melhor que o desemprego. Fuja da universidade. A idéia de que o canudo atrai grana é uma furada" (BURGOS, Pedro. Diploma não dá dinheiro. In: Superinteressante, n. 245, nov. 2007. São Paulo: Editora Abril, p. 25.). Na mesma matéria faz-se referência a pesquisa desenvolvida pela Universidade Cândido Mêndes, do Rio de Janeiro, que constatou que o desemprego entre bacharéis em direito quase quadruplicou nos últimos 10 anos e, entre os que têm trabalho, quase metade não atua na área de formação. Emais, constarou-se que no mercado de direito no Brasil, 38\% dos bacharéis trabalham na área jurídica, 37\% trabalham em outras áreas e $25 \%$ estão desempregados. (Ibidem, p. 27).
} 
empregos bem remunerados não se limita à economia americana e aponta dados surpreendentes referentes a outros países desenvolvidos ${ }^{444}$.

Em outra passagem o aludido autor destacou, ao analisar a forma como os sindicatos americanos reagiram aos reflexos da automação e da informatização nos postos de trabalho, que, conquanto estivessem corretos em sua crença de que a automação reduziria a quantidade de funções para a mão-de-obra qualificada, os sindicatos superestimaram grosseiramente o número de cargos de alta qualificação que poderiam sem criados pela nova tecnologia. Isto decorreria do fato de os sindicatos terem sido incapazes de enfrentar a principal dinâmica da revolução da automação, qual seja a firme determinação do empresariado de substituir trabalhadores por máquinas tanto quanto possível e, com isso, reduzir encargos trabalhistas, aumentar o controle sobre a produção e melhorar as margens de lucro. Com isso, embora alguns trabalhadores tenham encontrado empregos melhores em funções altamente qualificadas após terem sido dispensados; a maioria não conseguiu porque havia trabalhadores demitidos demais para os muitos poucos novos empregos especializados sendo criados ${ }^{445}$.

Em outra relevante passagem o autor em destaque ponderou que "O declínio da classe média se faz sentir mais acentuadamente entre as pessoas com formação universitária" e que os trabalhadores com formação universitária constituem a massa dos cargos de nível gerencial na economia americana, que são justamente os que estão sendo varridos pelos novos avanços tecnológicos e pelas práticas de reengenharia. Para ilustrar suas conclusões, acentuou que "mais de $35 \%$ dos recém-formados foram forçados a aceitar empregos que não requerem

\footnotetext{
${ }^{444} \mathrm{Na}$ Alemanha, a Siemens, gigante da eletrônica e da engenharia, achatou sua estrutura administrativa, cortou custos em 20 a 30\% em apenas três anos e demitiu mais de 16 mil funcionários em todo o mundo. Na Suécia, a ICA, cooperativa de alimentos com faturamento de US\$ 7,9 bilhões, sediada em Estocolmo, aplicou a reengenharia em suas operações, instalando um sistema informatizado de controle de estoque de última geração. A nova tecnologia poupadora de mão-de-obra permitiu que a empresa de alimentos fechasse um terço de seus armazéns e centros de distribuição, reduzindo seus custos gerais para metade. Com essa medida, a ICA conseguiu eliminar mais de 5 mil funcionários, ou seja $30 \%$ de toda sua força de trabalho, em apenas três anos, enquanto a receita cresceu mais de $15 \%$. No Japão, a empresa de telecomunicações NTT, anunciou sua intenção de cortar 10 mi funcionários em 1993 e afirmar que, como parte de seu programa de reestruturação, as demissões chegariam a 30 mil - 15\% da sua força de trabalho (RIFKIN, Jeremy. O fim dos empregos: o declínio inevitável dos níveis dos empregos e a redução da força global de trabalho. Tradução: Ruth Gabriela Bahr. São Paulo: Pearson Education do Brasil, 2001, p. 4/5).

${ }^{445}$ Ibidem, p. 93.
} 
formação superior, $15 \%$ a mais do que há cinco" e fez remissão à estatísticas compiladas pelo Michigan State University College Emloyment Research Institute, segundo quem o mercado de trabalho para pessoas com formação universitária atualmente é o pior desde a II Guerra Mundial. Ao final, concluiu expressamente que "as perspectivas são sombrias para muitos graduandos que aspiram a tornar-se parte de uma classe média americana minguante" ${ }^{, 46}$.

A realidade brasileira não é diferente. Em interessante estudo sobre os empregados formais entre 40 e 64 anos de idade por nível de instrução na Região Metropolitana de Natal entre 1996 e 2002, Daniela Lustoza Marques de Souza Chaves observou ser o segundo grau, ou nível médio de ensino, o grau de escolaridade mais exigido pelos empregadores e o que mais empregou trabalhadores com mais de 40 anos, a partir do ano 1995, com exceção, apenas dos anos 1999 e 2002. E acrescenta ainda que o nível superior, que antes de 1995 comportava mais trabalhadores nessa faixa etária que o nível médio de ensino, no final do período pesquisado ocupava apenas o terceiro lugar entre os graus de instrução a agregar maior número de trabalhadores na faixa etária de 40 anos ou mais ${ }^{447}$. Esses dados demonstram que na faixa etária e localidade pesquisada, hoje a procura é maior pelos trabalhadores sem formação universitária. A própria autora citada se encarrega de apresentar uma possível justificativa para essa constatação tão alarmante, ao ponderar que esse fato pode decorrer do aumento de emprego em empresas interpostas, através das terceirizações das atividades, que se multiplicaram na década de 90, exigindo o segundo grau para a maior parte de suas ocupações, e do fato desse período haver suportado as reestrurações nas empresas e privatizações, com adesão de empregados de bancos e empresas estatais aos PDVs, retirando do mercado de trabalho formal parcela de trabalhadores com nível superior ${ }^{448}$.

Num contexto em que o número de empregos não qualificados tende a aumentar mais do que o número de empregos qualificados, impedir alguém de se candidatar ou despedi-lo arbitrariamente porque é mais qualificado do que o cargo que ocupa, configura inequívoca violação ao seu direito ao

\footnotetext{
${ }^{446}$ Ibidem, p. 189.

447 CHAVES, Daniela Lustoza Marques de Souza. Mercado de trabalho e discriminação etária: a vulnerabilidade dos trabalhadores envelhecentes. São Paulo: LTr, 2006, p. 82.
} 
trabalho. Afinal, o que fará o trabalhador que não consegue encontrar emprego correspondente a sua qualificação e não é aceito em funções menos qualificadas do que a sua?

Ora, há um conhecido ditado popular, cuja aplicação a este estudo aplica com perfeição, que diz que quem pode o mais pode o menos. Se determinado cidadão está habilitado para o exercício de funções que demandam mais qualificação, em geral estará ele apto, também, para o exercício de funções menos qualificadas.

Não restam dúvidas de que as hipóteses de discriminação por sobrequalificação indireta tendem a ser muito mais freqüente do que as diretas. Mas, nada impede que se verifiquem, na prática, hipóteses de discriminação direta. Situações hipotéticas, apenas para exemplificar, seriam as da Faculdade que anuncia já na divulgação da vaga que somente poderão concorrer candidatos com mestrado, não se admitindo candidatos doutores, e da empresa que ao receber o currículo ou mesmo após a entrevista, avaliação ou dinâmica de grupo informa ao candidato que ele está sendo excluído do processo seletivo por ser qualificado demais.

É pouco provável - porém não impossível -, uma situação de discriminação por sobrequalificação da modalidade "impacto adverso", estudada no item 6.3., mediante a utilização de testes padronizados (scored tests). Não é de se imaginar usual a utilização de testes que beneficiem empregados menos qualificados em detrimento de outros mais qualificados para mascarar uma discriminação. O que não significa que isto, eventualmente, não possa ocorrer.

7.2. DISCRIMINAÇÃO POR SOBREQUALIFICAÇÃO NA VIGÊNCIA DO CONTRATO DE TRABALHO.

${ }^{448}$ Ibidem, p. 82. 
É comum ouvir-se falar que a obtenção de determinada titulação ou o incremento da qualificação profissional de determinado empregado seja causa de ciúme e inveja no ambiente do trabalho. O economista entrevistado, ao ser questionado se sentia hostilizado por outros empregados menos qualificados do que ele, assim respondeu:

Quando trabalhava no banco, sentia uma certa rivalidade por parte dos chefes de setor e da gerencia, até mesmo ouvi uma vez, quando estava perto de me formar o meu gerente administrativo falar que não valia a pena mandar meu diploma para o departamento pessoal, pois isso não iria mudar muito a minha função dentro do banco.

A reação relatada não chega a caracterizar uma conduta discriminatória. Diversas, no entanto, são as situações em que se pode identificar discriminação por sobrequalificação na vigência do contrato de trabalho, a maioria delas ligadas à promoção ou outra forma de premiação em que haja alguma avaliação subjetiva do empregador.

Um bom exemplo é o do superior hierárquico que, percebendo que um subordinado concluiu determinado curso, adquirindo assim um grau de formação profissional que o torna apto para novas responsabilidades dentro da empresa e pode chamar a atenção dos empregadores e fazê-los o escolherem para ocupar o seu posto de trabalho, passa a persegui-lo preterindo-o em todas as promoções e o avaliando mal em todas as oportunidades. Seria o caso do advogado que se sente ameaçado porque determinado estagiário ou paralegal, notório pelo brilhantismo, bacharelou-se e foi aprovado no exame da ordem. Como com a sua inscrição na OAB ele passa a ser qualificado demais e a estar impossibilitado legalmente de permanecer como estagiário, a possibilidade de vir a ser efetivado como advogado justamente no posto de seu antigo superior faz com que ele passe a persegui-lo. Outro exemplo ilustrativo seria o de um gestor que passa a discriminar subordinado por temor de que o fato deste ter concluído um Master of Business Administration (MBA), título que ainda não possui, possa levá-lo a tomar o seu cargo.

Neste caso, como se pode facilmente perceber, o motivo do tratamento diferenciado recebido pelo empregado consiste em uma melhora 
na sua qualificação que o torna demasiadamente qualificado para o cargo atualmente exercido e apto para o desempenho de uma nova função, o que torna os atuais exercentes desta atividade temerosos de perder o espaço ocupado. Pelos exemplos narrados poder-se-ia imaginar que a discriminação, nestes casos, parte sempre de um superior que receia ser substituído. Esta, efetivamente, talvez seja a situação mais fácil de ocorrer. É possível, contudo, imaginar situação em que o próprio empregador passe a discriminar empregado por estar ele muito qualificado para o posto exercido.

Pense-se na situação do empregado que, após concluir suas pós-graduações, torna-se mais titulado academicamente do que o seu empregador. Este fato, aliado ao contato mais próximo que ele tem com determinados clientes importantes, faz com o que o seu superior receie que ele decida montar seu próprio negócio, convidando-os a trabalhar consigo. Receoso de perder um grande cliente, e até mesmo de passar a ter um de seus subordinados de confiança como concorrente, o empregador passa a trocá-lo de carteira constantemente, subaproveitando a sua capacidade técnica, preterindo-o a outros menos qualificados nos afazeres mais relevantes. Tem-se, nestes casos, um tratamento desigual no tocante ao progresso na carreira fundado no excesso de qualificação do empregado, o que caracteriza outra hipótese de discriminação sobrequalificação ${ }^{449}$.

Como toda conduta discriminatória, essa prática pode desencadear uma série de problemas emocionais como desmotivação, melancolia e, em casos mais graves, depressão e estresse acentuado, razão pela qual precisa ser veementemente combatida.

\subsection{DISCRIMINAÇÃO POR SOBREQUALIFICAÇÃO NO MOMENTO DE EXTINÇÃO DO CONTRATO DE TRABALHO.}

\footnotetext{
${ }^{449}$ A conduta descrita poderia ser classificada como assédio moral, o que não a descaracteriza como uma
} forma de discriminação. A conduta assediadora consistente em tratar de forma mais rigorosa e, portanto 
Por fim, há que se ressaltar ainda a possibilidade da discriminação ser perpetrada justamente no momento de rescisão do contrato de trabalho, situação que se verifica, v.g., quando determinado grupo de empregados é eleito para dispensa justamente por apresentar qualificação superior à demandada para a função por eles ocupada. Mais uma vez a linha que separa o exercício regular do poder diretivo do empregador da conduta manifestamente discriminatória é tênue.

Não obstante não se questione ser inerente ao poder diretivo do empregador o direito de selecionar quem continuará a lhe prestar serviços e quem deixará a empresa, caso ele resolva, ao invés de fazer escolhas aleatórias, eleger um determinado grupo com características próprias para ser dispensando, sua escolha não pode ser pautada por critérios arbitrários, devendo guardar alguma correlação lógica com a atividade desenvolvida. Em outras palavras, se o empregador necessita dispensar vinte empregados e os escolhe de forma aleatória entre os seus funcionários, estará exercendo livremente o seu poder diretivo. Se, contudo, escolhe para dispensa exclusivamente os que estão acima do peso, sem que esta característica possa ser um fator de mau desempenho da função desempenhada, ou os que possuem opção sexual não ortodoxa, haverá uma censurável e ilícita conduta discriminatória.

Em um de seus textos, Márcio Túlio Viana destacou que "O empregador pode escolher entre João e Pedro, ainda que não explique os motivos, e mesmo que não tenha motivos. Mas não pode preferir Pedro, por exemplo, em razão de sua cor" ${ }^{\prime 450}$. A explicação é simples. A legislação brasileira não exige que o empregador apresente um motivo justo para fundamentar a sua escolha. Veda, porém, que esta seja pautada por um motivo injusto e, por conseguinte, discriminatório.

O professor entrevistado afirma suspeitar também ter sido vítima de discriminação por sobrequalificação no momento de extinção do contrato de trabalho com uma Instituição de Ensino Superior. Em seu relato afirma que após ter escutado de pessoas de dentro de uma universidade na qual lecionara por seis

desigual, determinado empregado em decorrência de um motivo que não se justifica, constitui também censurável forma de discriminação.

${ }^{450}$ VIANA, Márcio Túlio. A proteção trabalhista contra atos discriminatórios: onde termina o discurso e começa a realidade. In: VIANA, Márcio Túlio e RENAULT, Luiz Otávio Linhares (coord.). Discriminação. São Paulo: LTr, 2000, p. 358. 
anos que havia cortes baseados na qualificação dos empregados, o que o tornaria um dos cotados para a dispensa, passou a sentir-se perseguido injustificadamente pela coordenadora de um dos cursos que lecionava, e foi dispensado em seguida sob o pretenso argumento de carga-horária insuficiente. Seu relato denota que ele se sentiu vítima de discriminação indireta na medida em que sob o argumento formal de que ele teria carga-horária insuficiente, assertiva frágil sobretudo porque a distribuição da carga horária é feita, via de regra, de forma discricionária pela coordenação, ele na verdade fora dispensado porque a sua qualificação encarecia os custos operacionais, o que financeiramente tornaria mais interessante recrutar alguém com menor titulação.

Há que se salientar que conquanto prevaleça o entendimento de que vigora no Brasil o sistema de dispensa imotivada mediante o pagamento de verbas rescisórias, segundo o qual o empregador não precisa motivar a dispensa de seus empregados bastando para a rescisão contratual que sejam pagas corretamente todas as verbas rescisórias, este direito do empregador não pode ser exercido de forma abusiva. Como salienta Leonardo Vieira Wandelli,

No espaço da empresa, a ausência de critérios jurídicos para a despedida produz irracionalidade, mesmo do ponto de vista econômico, e um tipo especial de reprodução da razão cínica em que a manipulação do dano e do sofrimento e a distorção comunicacional estratégica, com a participação zelosa dos sujeitos, fazem do trabalho humano palco de instrumentalização total das pessoas. É, do ponto de vista constitucional, a negação da dignidade da pessoa humana que se expressa, no direito do trabalho, como incapacidade de dizer a injustiça que pode ser dita. $\mathrm{O}$ círculo mais restrito dos profissionais do direito absorve e reproduz essa instrumentalização que domina o círculo mais amplo dos intérpretes da Constituição ${ }^{451}$.

No exemplo citado, a dispensa mostra-se abusiva por uma série de fatores. A escolha dos professores que serão dispensados a partir de sua titulação e qualificação profissional viola o artigo 206, V da Constituição Federal que estatui que o ensino será ministrado com base no princípio da valorização dos profissionais do ensino. Não há como se imaginar maior desprestígio ao profissional do ensino do que o fato dele, após todo o sacrifício empreendido para obter determinada

${ }^{451}$ WANDELLI, Leonardo Vieira. Op. cit., p. 452. 
titulação acadêmica, ser dispensado porque esta encarece os custos da atividade empresarial.

Não fosse isto o bastante, se a educação deve visar ao pleno desenvolvimento da pessoa e sua qualificação para o trabalho, não é admissível que alguém seja dispensado justamente porque buscou se desenvolver e se qualificar para o trabalho.

Vê-se, portanto, que a conduta descrita além de contrariar o direito dos empregados ao desenvolvimento subjetivo, mormente o seu direito ao trabalho, mostra-se incoerente com a própria lógica do ensino superior, pautada sempre por análises meritocráticas (artigo 206,V da Constituição Federal) ${ }^{452}$.

Ora, para o ingresso em estabelecimentos do ensino superior é preciso aprovação prévia em exame vestibular, pautado sempre por análise meritocrática, seja quando realizado em prova única, seja quando realizado em exames seriados ou com aproveitamento das avaliações do Exame Nacional do Ensino Médio(ENEM). Para a consecução de financiamento para pesquisas também se realiza uma análise meritocrática que inclui, entre outras coisas, análise curricular. Para o ingresso no magistério superior em instituições públicas e em algumas instituições privadas confessionais, exige-se prévia aprovação em concurso de prova e de títulos para os quais a conclusão de curso de pós-graduação, sobretudo os de pós-graduação stricto senso apresenta peso considerável. Normas do Ministério da Educação e Cultura (MEC) exigem de todo estabelecimento de ensino superior um percentual determinado de mestres e doutores em seus quadros. A Lei 9.394/96 estabelece, em seu artigo 43, V que a educação superior tem por finalidade suscitar o desejo permanente de aperfeiçoamento cultural e profissional. Por fim, como bem salientou Newton Sucupira na epígrafe da obra da Fundação Nacional de Desenvolvimento do Ensino Superior Particular (FUNDANESP):

Um programa eficiente de estudos pós-graduados é condição para se conferir à nossa universidade o caráter verdadeiramente universitário, para que deixe de ser

452 “Art. 208. O dever do Estado com a educação será efetivado mediate a garantia de: (...) V - acesso as níveis mais elevados do ensino, da pesquisa e da criação artística, segundo a capacidade de cada um”. 
instituição apenas formadora de profissionais e se transforme em um centro criador de ciência ${ }^{453}$.

Qual valor deve preponderar? O direito individual do professor de não ser discriminado e de se autodesenvolver e o interesse estatal em fomentar a educação, que fatalmente acaba sendo atingido, porquanto a conduta empresarial descrita implica desestímulo a busca por mais capacitação, ou a liberdade do empregador de disciplinar a atividade econômica? A resposta pode ser extraída da seguinte lição do Professor Marcus Orione Gonçalves Correia:

Se tivéssemos um cotejo entre o princípio de liberdade de contratar e o princípio da não discriminação racial, como resolvê-lo? A pessoa teria livre possibilidade de contratar pessoas de qualquer raça, em detrimento, por exemplo, de princípios, como o da não-discriminação? Esse seria um cotejo perfeitamente ocorrente no dia-a-dia. Como se percebe, o princípio da não-discriminação estaria, já de início, bem mais próximo da dignidade humana/Democracia do que o princípio da liberdade de contratar. É óbvio que em hipóteses concretas teríamos a possibilidade de que o princípio da liberdade de contratar pudesse até estar próxima da binômia dignidade /Democracia. No entanto, como existem princípios como o da não-discriminação, e que estão naturalmente mais próximos da dignidade humana, há uma dificuldade de se encontrar hipóteses em que a liberdade de contratar pudesse fazer com que fosse possível a discriminação ${ }^{454}$.

Ora, se a dignidade da pessoa humana representa o valor maior da democracia brasileira, e o princípio da não discriminação encontra-se bem mais próximo dela do que a liberdade e o pode diretivo do empregador, não se pode justificar a preterição de candidato sobrequalificado para o caso por razões econômicas, como ocorreu na seguinte hipótese de discriminação por sobrequalificação noticiada na rede mundial de computadores:

\footnotetext{
${ }^{453}$ FUNDAÇÃO NACIONAL DE DESENVOLVIMENTO DO ENSINO SUPERIOR PARTICULAR (FUNDANESP). Legislação e Normas da Pós-Graduação Brasileira. $\quad 3^{\mathrm{a}}$ edição. Brasília: FUNDANESP, 2007, p. 6

${ }^{454}$ CORREIA, Marcus Orione Gonçalves. Direitos Humanos e Direitos Sociais: Interpretação Evolutiva e Segurança Social. In: Revista do Departamento de Direito do Trabalho e da Seguridade Social. São Paulo, Departamento de Direito do Trabalho e da Seguridade Social da Faculdade de Direito da USP, v.1, n.1, jan/jun 2006, p 127.
} 
Universidade $^{455}$ demite professores por seu alto grau de formação acadêmica.Por Lucas Guedes 29/06/2006 às 20:14.

Pelo menos 38 professores foram desligados do corpo docente da Universidade ${ }^{456}$, em São Paulo, esta semana. O motivo das demissões, segundo fontes ligadas à instituição, é a falta de recursos financeiros para pagar os salários dos professores doutores, que estariam "custando" caro aos cofres da universidade.

Mais uma situação que reflete a crise intelectual das universidades privadas no Brasil: o embate entre dinheiro e qualidade do ensino superior. Pelo menos 38 professores foram desligados do corpo docente da Universidade ${ }^{457}$, em São Paulo, esta semana. O motivo das demissões, segundo fontes ligadas à instituição, é a falta de recursos financeiros para pagar os salários dos professores doutores, que estariam "custando" caro aos cofres da universidade. A Universidade $^{458}$ ainda não se pronunciou oficialmente, mas o coordenador do curso de Comunicação Social, (...), confirmou a demissão de uma das professoras alegando a reestruturação da universidade. "Infelizmente, não há o que ser feito", diz. A aluna do último semestre de Jornalismo, Michele Prado, acha a situação um absurdo. "Como em uma universidade, que pelo menos na teoria deveria primar pela qualidade de ensino faz uma coisa dessas?", questiona. A indignação não vem só de Michele. $\mathrm{O}$ assunto tomou conta das listas de discussão que alunos de diferentes cursos mantêm na Internet. Mas nem todos compartilham da mesma opinião. Para Rafael Martins, aluno de Publicidade e Propaganda, os estudantes estão fazendo tempestade em copo d'água. "Se as professoras foram demitidas, por corte ou não, por economia ou não, por competência ou não, não é da nossa alçada", enfatiza. A informação mais recente é que os professores serão substituídos a partir do mês de agosto, mas muitos alunos, principalmente os último-anistas, estão preocupados com esta substituição. Alguns dos profissionais demitidos estavam orientando seus projetos de término de conclusão de curso e precisaram abandonar seus postos. Além disso, os estudantes classificam a ação como uma falta de respeito aos professores e alunos. A universidade, que alega falta de dinheiro, gastou R $\$ 2$ milhões em 2003 para comemorar a festa de seus 30 anos $^{459}$.

Embora o exemplo do professor discriminado seja perfeito para demonstrar uma situação de discriminação por sobrequalificação no momento de extinção do contrato de trabalho, certo é que não é apenas esta categoria

\footnotetext{
${ }^{455} \mathrm{O}$ nome da instituição de ensino superior foi propositalmente omitido.

${ }^{456} \mathrm{O}$ nome da instituição de ensino superior foi propositalmente omitido.

${ }^{457} \mathrm{O}$ nome da instituição de ensino superior foi propositalmente omitido.

${ }^{458} \mathrm{O}$ nome da instituição de ensino superior foi propositalmente omitido.

${ }^{459}$ Disponível em < http://www.midiaindependente.org/pt/blue/2006/06/356928.shtml>. Acesso em 12 de janeiro de 2008.
} 
de trabalhadores que está sujeita a este tipo de situação. Qualquer empregado que busque se aperfeiçoar e se qualificar para o trabalho pode ser vítima de uma discriminação desta natureza. Os exemplos do estagiário que se bacharelou e foi aprovado no exame da ordem, do subordinado porque concluiu um MBA sem que o seu superior possua semelhante titulação e do advogado que cursou pós-graduação e está ganhando notoriedade também servem para elucidar esta hipótese. Basta que o empregador ou superior imediato não se contenha em persegui-lo ou preteri-lo em promoções e premiações e decida dispensá-lo porque com a nova titulação ele se tornou uma ameaça ao seu posto de trabalho, ou no último caso ao seu empreendimento.

\subsection{CONCEITO DE DISCRIMINAÇÃO POR SOBREQUALIFICAÇÃO.}

Discriminação veio a ser conceituada como a conduta ou ação de estabelecer diferenças que violem o direito de pessoas com base em

critérios injustificados e injustos ${ }^{460}$ e sobrequalificação, como a qualidade do empregado que possui formação superior à complexidade das tarefas que realiza. Podese então definir discriminação por sobrequalificação como o ato de excluir previamente algum candidato de processo seletivo para obtenção de emprego, obstar o crescimento de um empregado dentro da empresa ou extinguir sua relação de emprego em razão dele apresentar formação superior à exigida pela complexidade das tarefas que realizam.

Há que se considerar que a simples opção por um trabalhador menos qualificado para a função, a escolha de um empregado com currículo menos expressivo ou a dispensa de um empregado menos titulado quando havia outros mais titulados não caracteriza, por si só, uma discriminação por sobrequalificação. Pode haver situações em que a preferência pelo empregado menos qualificado se justifica por outras razões, como, v.g., o fato dele gozar de maior

${ }^{460}$ CARLOS, Vera Lúcia. Op. cit., p. 28. 
confiança do empregador ou de ser mais vocacionado para aquela atividade menos qualificada do que os empregados mais titulados.

A caracterização deste ilícito trabalhista não é estritamente objetiva. Não é possível se concluir de maneira absoluta que sempre que se preferir um empregado menos qualificado ao mais qualificado haverá uma discriminação, muito menos que isto deva ser presumido. É imprescindível que se verifique se o critério da escolha foi justamente sua maior qualificação e não outros aspectos como indisciplina, descompromisso, fidúcia, etc. Constatado que o critério da escolha foi justamente a maior qualificação de um dos candidatos em disputa, ter-se-á uma discriminação por sobrequalificação ainda que ela se paute também por razões econômicas. Em outras palavras, estará caracterizada a discriminação por sobrequalificação sempre que o empregador conscientemente prejudicar um trabalhador por ser ele mais qualificado do que o necessário, ainda que o faça por razões econômicas. É o caso da dispensa de professores mais titulados para contratação de professores menos titulados com salários mais baixos ${ }^{461}$. Embora o objetivo principal do empregador seja a redução de custos, o simples fato dele conscientemente utilizar como critério para fazê-lo a maior titulação de alguns empregados é o suficiente para caracterizar o ilícito em questão. Outro exemplo é o do empregador que deixa de recrutar o trabalhador mais qualificado por temor de que ele abandone a função logo que encontrar um trabalhado compatível com sua formação, obrigando-o a contratar e treinar um novo empregado. Ora, o receio do empregador de ter prejuízos com novo treinamento caso contrate empregado sobrequalificado para determinada função não pode justificar uma violação do direito deste ao trabalho. E se ele nunca encontrar uma função compatível com sua formação? Ficará eternamente sem emprego porque os seus empregadores estarão sempre na expectativa de sua saída para trabalhar na função para a qual se preparou? Veja-se, por exemplo, que entre os entrevistados há um economista de formação que embora tenha se graduado em economia há mais de quinze anos, há

\footnotetext{
${ }^{461}$ O Juiz Titular da $89^{\text {a }}$ Vara do Trabalho de São Paulo, em interessante decisão prolatada em 24 de abril de 2007 nos autos da reclamação trabalhista tombada com o número 00004.2007.089.02.007, chamou a atenção para o fato de o preposto da universidade ré, em seu depoimento pessoal haver afirmado textualmente o seguinte: "evidentemente a reclamada está fazendo contratações em que trabalha o reclamante na busca de pessoas com menor qualificação e, portanto, menores salários". E ao final asseverou: "Vil iniciativa de provocar a rotatividade de mão-de-obra, para obter barateamento dos custos produtivos. Ato reprovado, diuturnamente, pela Justiça do Trabalho em qualquer área de organização mercantil, que não pode ser abraçado, no caso de uma escola de direito, da qual saíram tantos importantes juslaboralistas”.
} 
muito tempo vem se contentando em exercer funções não ligadas a esta área, contentando-se hoje em desempenhar um serviço técnico que não demanda formação de nível superior.

Ademais, redução de custos nunca foi um argumento válido para respaldar práticas discriminatórias. Admitir o contrário resultaria em possibilitar que o empregador deixasse de contratar mulheres em idade fértil porque se o fizesse teria despesas com a contratação e treinamento da pessoa que a substituiria durante a licença maternidade, bem como de contratar portadores de necessidades especiais em razão dos custos que teria com a adaptação do local de trabalho.

A gravidade da discriminação por sobrequalificação se acentua em um país como o Brasil, onde o desemprego é maior entre os que completaram o ensino médio do que entre os analfabetos e muitos diplomados por universidade só conseguem trabalhar quando aceitam um emprego de nível médio ${ }^{462}$.

Não obstante o aumento na oferta de pessoas com nível médio nos últimos anos, o número de pessoas formadas neste nível também aumentou consideravelmente. Segundo José Pastore, em 1995, o Brasil formou 997 mil pessoas no nível médio e em 2004, 1,9 milhão. E na falta de empregos adequados, muitas foram obrigadas a aceitar trabalhos de renda mais baixa ou ficar desempregadas ${ }^{463}$.

A mesma regra foi percebida no ensino superior, em que o número de concluintes em todos os cursos subiu de 246 mil em 1995 para 625 em 2004, e na ausência e oportunidades à sua altura, os diplomados pelas universidades saem em busca e empregos que requerem qualificação mais baixa, contribuindo para o desemprego e rebaixamento da sua renda ${ }^{464}$.

É preciso, portanto, identificar meios de combater a discriminação por sobrequalificação. Se não se identificar logo formas de fazê-lo, o número de casos tende a aumentar na medida em que a qualificação dos brasileiros,

\footnotetext{
462 PASTORE, José. As mudanças...op cit, p. 236.

${ }^{463}$ Ibidem, pp. 236/237.

${ }^{464}$ Ibidem, pp. 236/237.
} 
embora permaneça bem aquém do desejável, tem melhorado nos últimos anos, e o número de empregos qualificados não tem acompanhado este crescimento, como ressaltado acima. Segundo pesquisa realizada pelo IBGE, entre 1993 e 2003, os brasileiros de dez anos ou mais que tinham, em média, 5 anos de escola, têm hoje 6,4 anos e a proporção dos brasileiros que têm 11 anos ou mais de estudo passou de 14,4\% em 1993 para 24,9\% em $2003^{465}$. E isto apenas aumenta o número de potenciais vítimas da discriminação aqui tratada.

A proliferação da discriminação por sobrequalificação pode, entre outros malefícios, frustrar os jovens, dando-lhes a sensação de que a educação é inútil. E, como salienta José Pastore, nada poderia ser mais falso, exatamente porque "se os tempos estão difíceis com uma população educada, eles serão catastróficos com uma população ignorante" ${ }^{466}$.

Ressalte-se, porém, a necessidade de muita cautela ao se analisar supostos casos de discriminação por sobrequalificação. Pode haver casos em que conquanto o empregador tenha possibilitado ao empregado sobrequalificado todas as oportunidades de concorrer a uma vaga com outros menos qualificados, optou, por razões não discriminatórias, pela contratação de trabalhador com menos formação. E casos em que a empresa em processo de reestruturação dispense funcionários que, apesar de mais qualificados, apresentavam produtividade inferior à dos demais colegas. Nestes dois casos, é natural que os empregados preteridos e dispensados sintam-se injustiçados e, possivelmente, imaginem-se vítimas de uma discriminação não verificada. A explicação é muito simples. Tanto a preterição em um processo seletivo quanto a dispensa são processos em geral traumáticos e difíceis de assimilar. É natural, portanto, que em situações deste gênero os empregados busquem se eximir de sua responsabilidade pelo fracasso imputando-a a outra pessoa.

\subsection{TIPOS DE DISCRIMINAÇÃO POR SOBREQUALIFICAÇÃO}

\footnotetext{
${ }^{465}$ Pesquisa Nacional por Amostra de Domicílios. Rio de Janeiro: IBGE, 2003.

${ }^{466}$ PASTORE, José. As mudanças...op. cit., p. 237.
} 
A discriminação por sobrequalificação também pode ser direta quando se evidenciar expressamente que o tratamento desigual funda-se na sobrequalificação, ou indireta quando se confere um tratamento formalmente igual, mas que, no resultado, se traduz em efeito diverso sobre os funcionários mais qualificados. Exemplo da primeira hipótese tem-se na situação do professor entrevistado que foi preterido em escolas do ensino médio sob a alegação de que seu currículo estava além do necessitado pelas escolas e que seu grau de intelectualidade poderia ficar acima da compreensão dos alunos. Exemplo da segunda verifica-se quando uma Instituição de Ensino Superior justifica dispensas em massa alegando estar procedendo a uma reestruturação em seus quadros e uma reformulação na carreira, mas ao se analisar os funcionários desligados percebe-se que todos eles eram doutores e mestres. Os professores apenas graduados, cujos salários eram bem mais baixo, não foram alvo da reestruturação de seus quadros.

No tocante à dicotomia entre discriminação negativa e discriminação positiva, exposta no item 6.2, há que se destacar que apenas a primeira tem lugar quando se fala em discriminação por sobrequalificação. A explicação é bastante simples. Os empregados sobrequalificados não precisam de favorecimento legal para serem inseridos em postos que não demandam os conhecimentos adquiridos em sua formação profissional. Eles não apresentam desvantagem material em decorrência de fatores naturais ou históricos. A sobrequalificação não pode ser considerada uma desvantagem para o empregado, vez que ela apenas amplia o seu leque de opções para incluir além das funções que poderiam ser exercidas sem sua formação específica, as atividades inerentes a esta. Ademais o empregado discriminado em razão de sua sobrequalificação não é vítima de preconceitos ou estereótipos. $\mathrm{O}$ empregador não o pretere em razão de possuir um sentimento de repulsa contra profissionais muito qualificados. Os fatores que o levam a preteri-lo são, como já afirmado, de ordem subjetiva (como, por exemplo, o temor de que ele venha a ocupar seu espaço na empresa) ou de ordem econômica. 


\subsection{EFEITOS DA DISPENSA DISCRIMINATÓRIA EM RAZÃO DE SOBREQUALIFICAÇÃO.}

A discriminação por sobrequalificação viola o princípio-regra da dignidade da pessoa humana ao desrespeitar o direito da vítima ao desenvolvimento subjetivo em suas três vertentes, direito à educação, ao trabalho e à formação profissional, e ao ferir o seu direito à igualdade. Pode, outrossim, ser combatida com a adoção da teoria da horizontalização dos direitos fundamentais que, como visto, já vem sendo acolhida pelos pretórios brasileiros.

Mas não é só. Por ser uma modalidade de discriminação como qualquer outra, aplicam-se-lhe as cominações da Lei 9.029/95, que, como visto no item 6.3.6., é, segundo entendimento dominante, aplicável a todas as formas de discriminação e não apenas aquelas mencionadas expressamente no seu artigo $1^{\circ}$. Por esta razão em caso de dispensa discriminatória em razão da sobrequalificação do empregado este possui a faculdade de optar entre sua readmissão com ressarcimento integral de todo o período de afastamento, mediante pagamento das remunerações devidas, corrigidas monetariamente, acrescidas dos juros legais; ou, a percepção, em dobro, da remuneração do período de afastamento corrigida monetariamente e acrescida dos juros legais (art.4 ${ }^{\circ}$, Lei 9.029/95).

Ademais, qualquer dispensa por ato discriminatório deve ser reputada abusiva segundo a conceituação de Sérgio Torres Teixeira, porquanto concretizada por motivo ilegítimo, cuja relevância transcende a relação individual de emprego, constituindo violação expressa a princípios de fundamental interesse público e/ou social, ao ponto de ser considerado um abuso do direito desfrutado pelo empregador $^{467}$. E em assim sendo a dispensa pode ser anulada em juízo pela simples razão de ser abusiva como deixa transparecer o citado autor pernambucano:

A dispensa abusiva, pois, vai além da dispensa arbitrária, por caracterizar o exercício irregular de um direito previsto em lei, de forma a contraria a sua finalidade social, e que, em virtude dos efeitos nocivos causados pelo respectivo

${ }^{467}$ TEIXEIRA, Sérgio Torres. Op. cit., p. 160. 
excesso, enseja a anulação do ato resilitório. A causa geradora da resilição em decorrência da despedida abusiva, assim, qualifica a dispensa como um verdadeiro abuso de direito. Não há apenas a falta de um dos pressupostos caracterizadores da dispensa por justa causa e a ausência de motivo econômico, financeiro, disciplinar e técnico. Há uma causa transgressora de interesses estatais e sociais, gerando a anulabilidade do respectivo ato patronal ${ }^{468}$.

Este entendimento parece ser respaldado pelo colendo Tribunal Superior do Trabalho que em decisão paradigmática determinou a reintegração de um trabalhador discriminado por ser portador do vírus HIV com base na Constituição, independentemente de haver ou não norma instituindo estabilidade nestes casos:

Caracteriza atitude discriminatória ato de empresa que, a pretexto de motivação de ordem técnica, dispensa empregado portador de vírus HIV sem a ocorrência de justa causa e já ciente à época o estado de saúde em que se encontrava o empregado. $O$ repúdio à atitude discriminatória, objetivo fundamental da República Federativa do Brasil - artigo $3^{\circ}$, inciso IV -, e o próprio respeito à dignidade da pessoa humana, fundamento basilar do Estado Democrático de Direito - artigo $1^{\circ}$, inciso III -, sobrepõe-se à própria inexistência de dispositivo legal que assegure ao trabalhador portador do vírus HIV estabilidade no emprego (TST, ADV 20-04/309, n. 109801, E-RR 439.041/98, Rel. Min. João Dalazen)

Ora, anulada a dispensa discriminatória por abusiva, a conseqüência natural é o retorno ao status quo, no caso com o restabelecimento da relação de emprego, de modo que ainda que se considere inaplicável a Lei 9.029/95 a outras espécies de discriminação que não as relacionadas em seu artigo $1^{\circ}$, ou ainda que não existisse a referida norma, as dispensas discriminatórias poderiam ser anuladas em juízo por se consubstanciarem em abuso de direito.

468 Ibidem, p. 162. Leonardo Veira Wandelli destacou, em sua dissertação de mestrado, que "é a limitação da despedida abusiva que está a serviço da não constrição dos direitos fundamentais. Especialmente no âmbito do que se convencionou chamar de "direito privado", a teoria do abuso do direito reconstruída pode contribuir para a ultrapassagem dos limites que a racionalidade formalpositivista impunha a normatividade constitucional no âmbito das relações privadas - pela sua aparente metódica teorética-conceitualista-fetichizadora mas, em verdade, decisionista, não elaborada e parcial, pela sua resistência à normatividade dos princípios, peo seccionamento do direito em âmbitos incomunicáveis, pela leitura retrospectiva dos textos legais, interpretando a Constituição na forma da lei anterior. Assim sendo, o princípio do abuso de direito se converte em instrumento de efetividade da normatividade constitucional, inclusive dos direitos fundamentais - um princípio ponte enre o isolacionismo setorial e o sistema constitucional. WANDELLI, Leonardo Vieira. Op. cit., pp. 304/305. 
A discriminação por sobrequalificação com intuito de reduzir custos, como no exemplo citado da dispensa de professores mais titulados e que, por essa razão, recebem salários mais altos, representa também um exercício abusivo do direito à propriedade, haja vista que esta, segundo o artigo $5^{\circ}$, XXIII, deverá atender a sua função social. Segundo José Afonso da Silva, “a função social manifestase na própria configuração estrutural do direito de propriedade, pondo-se concretamente como elemento qualificante na predeterminação dos modos de aquisição, gozo e utilização dos bens". E se a constituição assegura uma educação que qualifique para o trabalho e o direito ao trabalho, ambos vertentes do direito ao desenvolvimento subjetivo, é evidente que ao dispensar empregados que investiram na sua qualificação e aperfeiçoamento profissional com o intuito de aumentar seus lucros, o empregador está exercendo o seu direito à propriedade sem atentar para a sua função social. Em verdade a dispensa de profissionais por serem muito qualificados e, por conseguinte, de alto custo para a empresa, desestimula o investimento pessoal em qualificação profissional. Faz com que os profissionais tenham receio de que a sua maior qualificação, ao invés de ser fator de aumento da empregabilidade, se torne fator de diminuição desta. E isto causa um prejuízo social imensurável. Sobretudo em um país onde os dados estatísticos dão conta de que a mão de obra ainda é muito pouco qualificada.

Ainda não se tem notícia de muitas ações ajuizadas com o intuito de anular dispensas discriminatórias por sobrequalificação do empregado. Uma possível explicação seria o errôneo dogma de que o empregador é livre para dispensar qualquer empregado não estável. A dispensa de um empregado pautada em sua qualificação ou formação acadêmica viola o seu direito ao desenvolvimento subjetivo e a igualdade, sendo, portanto, nula de pleno direito.

\subsection{EFEITOS DA DISCRIMINAÇÃO POR SOBREQUALIFICAÇÃO NA FORMAÇÃO E NO CURSO DO CONTRATO DE TRABALHO.}


A discriminação por sobrequalificação perpetrada no momento do recrutamento e no curso do contrato de trabalho, assim como a praticada no momento da extinção da relação de emprego, além de afrontar os direitos da vítima ao desenvolvimento e à igualdade, constitui hipótese típica de exercício abusivo de um direito. Conquanto o empregador possua o direito de recrutar seus empregados conforme suas necessidades e interesses, não lhe é dado o direito de fazê-lo com base em critérios injustos que firam o direito ao desenvolvimento subjetivo do empregado ou candidato, mormente nas suas vertentes direito ao trabalho e direito à formação profissional. Ao excluir alguém do processo seletivo ou mesmo da relação de emprego por ser ele mais qualificado do que o que necessário para o cumprimento das funções vagas, relegando-o ao desemprego, seja por temor de perder espaço para ele, seja por razões estritamente econômicas, o empregador extrapola os limites de seu poder diretivo, exercendo abusivamente um direito que lhe é assegurado por lei. De igual maneira, o empregador ou o superior hierárquico que impede o crescimento profissional de um de seus subordinados por temor de que ele venha a fazer-lhe concorrência no futuro ou ocupar seu posto de trabalho exerce abusivamente o seu poder diretivo.

No ordenamento jurídico brasileiro, o abuso de direito é equiparado ao ato ilícito, consoante se depreende do artigo 187 do Código Civil ${ }^{469}$. Leonardo Vieira Wandelli assevera que o ato abusivo "não viola diretamente a proibição do abuso e sim os conteúdos normativos positivados que deixam de ser considerados nas interpretações-padrão cristalizadas sob a proteção do formalismo positivista". Diversa seria a situação de uma decisão que desconsidera o abuso, em nome da interpretação padrão, que viola o princípio da coibição do abuso. A normatividade do princípio do abuso do direito independeria em seu ponto de vista, de norma expressa que o coíba, pois negar a coibição do abuso significaria negar a própria pretensão de coerência e correção inerente a todo ato de julgar segundo um ordenamento jurídico inteiramente considerado e significaria, portanto, a negativa do direito à igualdade de tratamento na aplicação da $1 \mathrm{e}^{470}$.

\footnotetext{
${ }^{469}$ Também comete ato ilícito o titular de um direito que ao exercê-lo excede manifestamente os limites impostos pelo seu fim econômico ou social, pela boa-fé ou pelos bons costumes.

${ }^{470}$ WANDELLI, Leonardo Vieira. Op. cit., p. 210.
} 
Mas não é só. A discriminação por sobrequalificação também implica em flagrante e ostensiva violação ao artigo 421 do Código Civil que estabelece que "a liberdade de contratar será exercida em razão e nos limites da função social do contrato". Este dispositivo consiste no que se convencionou chamar de cláusula geral. Uma norma intencionalmente formulada de maneira vaga e imprecisa, a fim de que o magistrado possa densificar o seu conteúdo. A concretização dela ocorrerá em maior ou menor grau, conforme a concretude dos interesses envolvidos ${ }^{471}$. No tocante aos contratos de trabalho de trabalhadores sobrequalificados os interesses envolvidos são o direito dos empregados ao desenvolvimento subjetivo, o interesse social na qualificação de seus profissionais e o direito ao trabalho, por um lado, e, pelo outro, o direito à propriedade, o poder diretivo e a liberdade de contratar e de demitir assegurados ao empregador. E, quando em confronto, é evidente que aqueles se sobrepõe a estes.

Após destacar que a função social não coíbe a liberdade de contratar, mas legitima a liberdade contratual, Nelson Rosenvald destaca que a função social interna concerniria à indispensável relação de cooperação entre os contratantes, por toda a vida da relação. Implicaria, portanto, a necessidade de os parceiros se identificarem como sujeitos de direitos fundamentais e titulares de igual dignidade, colaborando mutuamente nos deveres de proteção, informação e lealdade contratual, vez que a finalidade de ambos é o adimplemento, da forma mais satisfatória ao credor e menos onerosa ao devedor ${ }^{472}$.

Ao excluir do processo seletivo um empregado em razão de haver buscado aumentar sua empregabilidade qualificando-se mais do que o necessário para o cargo postulado, o empregador ignora seu direito fundamental à dignidade e ao desenvolvimento subjetivo. Ao dispensar alguém por haver se qualificado mais do que o necessário para o exercício de determinada função, o empregador afronta seu dever de lealdade contratual, o qual, aliás, resta ainda mais gravemente violado nas hipóteses de discriminação indireta, em que a conduta ilícita é travestida de conduta lícita.

\footnotetext{
${ }^{471}$ Nelson Rosenvald in PELUZO, Cesar(coord). Código Civil Comentado. Barueri-SP, Manole, 2007, p. 312.

${ }^{472}$ PELUZO, Cesar(coord). Código Civil Comentado. Barueri-SP, Manole, 2007, p. 312.
} 
Há que se destacar ainda que as hipóteses de discriminação indireta violam o artigo 422 do Código Civil, seja qual for o fator de discriminação. Segundo o referido dispositivo "Os contratantes são obrigados a guardar, assim na conclusão do contrato, como em sua execução, os princípios de probidade e boa-fé”. Com efeito, não age com boa-fé quem traveste de licitude uma conduta ilícita para fugir dos imperativos da lei.

Como se pode perceber, a discriminação por sobrequalificação verificada na formação e no curso do contrato de trabalho é tão ilícita quanto aquela ocorrida ao término do contrato. Contudo, como no caso da discriminação praticada na formação do contrato de trabalho ainda não houve a formação do vínculo empregatício, a sua conseqüência não pode ser a reintegração do empregado. Por outro lado, a reintegração é desnecessária no que se refere à discriminação praticada no curso do contrato de trabalho, haja vista que nesta hipótese o empregado encontra-se laborando normalmente.

Também não parece razoável impor ao empregador a contratação do empregado discriminado, pois isto afrontaria a liberdade de contratação do empregador. Há que se lembrar que não se vem defendendo o direito do empregado sobrequalificado ao posto vago, mas o seu direito a não ser excluído do processo seletivo por sua maior formação.

Diferente, entretanto, é a situação do empregado preterido em promoção em razão de sua maior formação, pelo menos quando houver na empresa plano de cargos e salários. Neste caso, é possível obter via reclamação trabalhista o novo enquadramento ou reclassificação, nos termos da Súmula 127 do Tribunal Superior do Trabalho.

Em todo caso, sempre será possível ação para pleitear reparação por danos morais. Se o trabalhador for discriminado na fase de seleção, ainda assim faz jus ao ressarcimento pelo dano moral sofrido, com fundamento na teoria da culpa in contraendo ou responsabilidade pré-contratual e também no princípio da boa- 
fé objetiva, que consiste no dever das partes de agirem com lealdade recíproca nas relações sociais ${ }^{473}$.

A jurisprudência vem sancionando os empregadores que discriminam seus empregados, fundamentando a condenação na Convenção n. 111 da OIT. O seguinte julgado do Tribunal Regional do Trabalho da $3^{\mathrm{a}}$ Região apresenta interessante solução, na medida em que, conquanto entenda que o rol da Lei 9.029/95 é número clausus, e, portanto, aplicável somente às hipóteses ali enunciadas, condenou a empresa a pagar danos morais por haver discriminado empregados que haviam ajuizado reclamação contra a antiga empregadora, por ela sucedida:

INDENIZAÇÃO POR DANOS MORAIS. DISCRIMINAÇÃO NO ATO DA ADMISSÃO. O princípio da igualdade, talhado ao longo dos séculos pelo homem e para o homem, é um autêntico direito fundamental delineador da personalidade humana e dirige-se tanto em face do Estado quanto do particular, que não pode pautar-se por condutas discriminatórias, preconceituosas ou racistas. No caso em tela, a prova oral e documental revelam que a $2^{\mathrm{a}}$ Reclamada teria prometido aos empregados da primeira reclamada a manutenção do emprego, com a sucessão trabalhista operada, a não ser quanto àqueles que "tivessem levado a Prosseguir à Justiça". No plano internacional, o Brasil ratificou a Convenção n. 111 da OIT, que trata da discriminação em matéria de emprego e ocupação, e que tem como principais preocupações a afirmação dos valores constantes da Declaração de Filadélfia, dentre os quais se inscrevem a igualdade de oportunidades, a dignidade e o progresso material, assim como a conscientização de que a discriminação constitui violação aos direitos enunciados na Declaração Universal dos Direitos do Homem. Observa Márcio Túlio Viana, em estudo em torno da Lei 9.029, de 13 de abril de 1995, que proíbe discriminações para efeito de acesso à relação de emprego, ou sua manutenção, por motivos "numerus clausus", de sexo, origem, raça, cor, estado civil, situação familiar ou idade, que o legislador já deixara de fora outras hipóteses previstas expressamente na Constituição, como as práticas discriminatórias decorrentes de deficiência (art $7^{\circ}$, XXXI)" (Viana, Márcio Túlio, "Proteção contra atos discriminatórios", In: O que há de novo em Direito do Trabalho", coordenadores. Márcio Túlio Viana e Luiz Otávio Linhares Renault, São Paulo: LTr, 1997, p. 97). Não significa isto que os juízes não estejam buscando uma solução equânime para as demais formas de discriminação. A jurisprudência, como fonte formal do direito, vem de algum tempo para cá, fornecendo subsídios

${ }^{473}$ CARLOS, Vera Lúcia. Op cit., p. 58 
preciosos para o intérprete. E é este o caso dos autos, em que nos deparamos com a discriminação por força de fator não inclú́do no rol da lei supracitada, mas igualmente odiosa,evoluindo a jurisprudência no sentido de ceifar, na raiz, as chamadas "listas negras". Lembre-se de que o direito de ação é constitucionalmente assegurado (art. 5, XXXV) e as chamadas "listas negras" são de há muito repudiadas pelo ordenamento jurídico, por impedir, injustamente, a admissão de trabalhadores que exerceram direito legitimamente assegurado. Assim, demonstrado que a atitude da Reclamada foi lesiva à honra e à intimidade do Reclamante, causando-lhe frustração pela oportunidade perdida, indubitável o dano moral ocasionado e a relação de causalidade entre o ato e o efeito, pelo que deve ser deferida a indenização específica, ressaltando ainda o caráter pedagógico da pena, que visa a coibir a prática discriminatória, pela Reclamada". (TRT $3^{\mathrm{a}}$ Região, RO 00951/2005, Relator: Fernando Luiz Gonçalves Rio Neto, DJMG 15.07.06). ${ }^{474}$

Também não se tem notícia de ação pleiteando indenização por discriminação perpetrada no momento de formação ou no curso de contrato de trabalho pelo motivo em razão da sobrequalificação do empregado. Os motivos mais prováveis são o desconhecimento acerca da ilicitude desta conduta e a crença de que o empregador é livre para contratar e promover quem ele quiser, não podendo, por conseguinte, ser obrigado a contratar este ou aquele candidato pelo simples fato dele apresentar titulação superior.

A conscientização acerca da ilicitude do problema, e a busca das vítimas pela reparação cabível, são as melhores formas de se tentar solucionar o problema. Ações afirmativas não são necessárias nem úteis para combater este tipo de discriminação não fundada, em regra, em preconceitos enraizados, mas em questões econômicas e receio de perda de espaço dentro do ambiente de trabalho.

\subsection{O IMPORTANTE PAPEL DA NEGOCIAÇÃO COLETIVA NO COMBATE À DISCRIMINAÇÃO POR SOBREQUALIFICAÇÃO.}

\footnotetext{
${ }^{474}$ In: Vianna, Cláudia Salles Vilela. Manual de práticas trabalhistas. $8^{a}$ edição. São Paulo: LTr, 2007, p. 49.
} 
Cumpre ressaltar que as normas coletivas, tão prestigiadas na Constituição Federal Brasileira, também podem desempenhar um importante papel no combate à discriminação por sobrequalificação. Até porque, como salienta Christiani Marques, a negociação coletiva é o meio de dinamização das relações sociais, atenuando os conflitos e discussões sobre divergência trabalhistas entre as partes, visando a um resultado, ou seja, a melhoria das condições de trabalho ${ }^{475}$.

Diante do desconhecimento que ainda paira sobre a discriminação por sobrequalificação e do equivocado dogma de que a liberdade de contratação e o poder diretivo do empregador permitem-lhe dispensar e preterir empregados sobrequaificados ao seu bel-prazer, a inclusão de cláusulas vedando a discriminação por sobrequalificação em normas coletivas pode ser fundamental no combate a este tipo de conduta perniciosa. Seria o caso, por exemplo, de os sindicatos de professores e de mantenedoras de instituições de ensino superior incluírem, em negociação coletiva, cláusula proibindo a dispensa de professores mais titulados para a contratação de outros menos titulados visando, com isso, apenas a redução de custos. Seria o caso também de as demais categorias profissionais incluírem norma assegurando aos empregados qualificados o direito de não ser excluído do processo seletivo para cargos que não demandem todos os conhecimentos adquiridos em sua formação profissional.

Em ambos os casos poder-se-á cominar uma multa convencional para as hipóteses de descumprimento da cláusula, a qual poderá, perfeitamente, ser cumulada com pedido de reintegração ou de indenização por danos morais.

Estas cláusulas prestariam dois papeis de fundamental relevância. Primeiramente esclareceriam as categorias que este tipo de discriminação é ilícito. Em segundo lugar, simplificariam as discussões por ocasião da prestação da

\footnotetext{
${ }^{475} \mathrm{Em}$ suas palavras: "Não obstante existam leis versando sobre conteúdos discriminatórios e igualdade, é importante a consciência de exterminar a causa, no sentido de a negociação coletiva poder ser a forma de preservar a defesa da dignidade do homem que trabalha" MARQUES, Christiani. Op. cit., p. 79.
} 
tutela jurisdicional, vez que não haveria mais espaço para discussões acerca da taxatividade ou não do rol do artigo $1^{\circ}$ da Lei 9.029/95 e do fundamento legal e constituição para a vedação deste tipo de comportamento.

\section{9. ÔNUS DA PROVA NAS AÇÕES RELATIVAS À DISCRIMINAÇÃO POR SOBREQUALIFICAÇÃO.}

Aplicando-se a regra sugerida no item $6.3, c$ deste trabalho, tem-se que o ônus da prova também nas ações em que há alegação de discriminação por sobrequalificação será do autor, não sendo razoável se falar em inversão imediata do ônus da prova. Lides em que se discutam essas matérias solucionar-se-ão perfeitamente pela distribuição ordinária do ônus da prova, prevista nos artigos 818 da CLT e 333 do Código de Processo Civil ${ }^{476}$. Ora, alegando o autor ter sido vítima deste ilícito trabalhista, cabe-lhe provar ter sido preterido na contratação ou na promoção por outro candidato ou outro empregado menos qualificado, ou ter sido dispensado quando havia outros empregados menos qualificados que poderiam sê-lo em seu lugar, fato constitutivo de seu direito à reintegração, ao enquadramento ou a indenização. Sendo certo que o ordinário se presume e o extraordinário deve ser provado e que, neste caso, o ordinário é a contratação do mais qualificado e a dispensa do menos qualificado, caberá ao réu provar que sua escolha não foi discriminatória, apresentando fatos modificativos, impeditivos ou extintivos do direito do autor.

\footnotetext{
${ }^{476}$ Como salienta Leonardo Vireira Wandelli, com quem se há de concordar: "Distribuição igualitária da carga probatória tampouco significa pré-juízo em desfavor do empregador. Portanto, não parece adequada uma regra rígida de inversão do ônus da prova, na qual seria sempre este quem deveria provar que não discriminou, independemente de quaisquer condições. Tem-se por inadequada, pois a aplicação analógica de maneira generalizada e indiscriminada, às situações de despedida, do art. $6^{\circ}$, VIII, da Lei 8.078/90, Código de Defesa do Consumidor, que estipula como direito básico do consumidor 'a inversão do ônus da prova, a seu favor, no processo civil, quando, a critério do juiz, for verossímil a alegação ou quando for ele hipossuficiente, segundo as regras ordinárias de experiência'. Embora o texto legal constitua o apoio a um avanço extraordinário em termos de tratamento igualitário das partes, a mera 'hipossuficência', a priori, não jutifica eximir-se o trabalhador em todo caso de produzir prova, ainda que de inícios e circunstâncias, do fato do qual decorre seu direito, sobretudo quando a prova negativa é excessivamente onerosa. A inversão do ônus da prova, propriamente dita, em aplicação analógica, depende da concreta conexão entre a hipossuficiência e a dificuldade excessiva de produção da prova. Assim, há de ser entendida como ato ope judicis e à vista da situação e não ope legis, aplicável indiscriminadamente a despeito da inexistência daquela conexão" (WANDELLI, Leonardo Vieira. $O p$. cit., p. 411.).
} 
$\mathrm{Na}$ pior das hipóteses, o autor deverá apresentar indícios que corroborem suas alegações como, por exemplo, um prima facie case, disparidades estatísticas como, por exemplo, redução acentuada da proporção entre doutores e empregados com menor titulação, ou qualquer outro fato que fundamente pelo menos suspeitas de que teria sido vítima do ilícito estudado. A simples alegação desprovida de qualquer comprovação, por mínima que seja, não é suficiente para justificar que se transfira para o réu a obrigação de provar que não praticou irregularidade alguma, invertendo-se o ônus da prova.

Fundamentada, pelo menos de forma indiciária, a alegação de discriminação o réu precisará apresentar uma razão legítima, não discriminatória para suas ações, cabendo ao autor, em seguida, demonstrar que essa justificativa não passa de um pretexto para mascarar um motivo ilegal.

Mesmo quando o empregado não possuir documentos que comprovem suas assertivas, melhor do que falar em inversão do onus probandi será fazer um requerimento na petição inicial para que o juiz determine que a parte contrária os junte sob pena de confissão.

Como matérias argüíveis em defesa pelo réu, e que, por conseguinte, caber-lhe-á provar em juízo, podemos citar aspectos disciplinares que justifiquem a dispensa do empregado sobrequalificado, maior produtividade dos empregados menos qualificados, pior desempenho do empregado sobrequalificado no processo seletivo, etc.

\subsection{JURISDIÇÃO METAINDIVIDUAL NO COMBATE À DISCRIMINAÇÃO POR SOBREQUALIFICAÇÃO.}

A discriminação por sobrequalificação poderá ainda ser combatida ou reparada através da jurisdição metaindividual. Contudo, como já 
observado, é preciso ressalvar que mesmo com todas as vantagens que o sistema de jurisdição coletiva pode oferecer no combate à discriminação no emprego, há que se ver com reservas a opinião de alguns autores que, conferindo interpretação demasiadamente ampliativa aos conceitos de interesses difusos, coletivos e individuais homogêneos, quase chegam a defender que em todas as hipóteses de discriminação seja possível o ajuizamento de ações civis públicas ${ }^{477}$.

É preciso analisar com cautela os impactos da conduta discriminatória para se determinar se houve violação a um interesse difuso, coletivo ou individual homogêneo que justifique a intervenção do Ministério Público do Trabalho, ou se se trata de violação a um direito individual ou individual heterogêneo que somente possa ser protegido pelas vítimas ou representantes. Também quanto a este ponto cumpre destacar que a análise deve ser feita casuisticamente, não sendo prudente tentar traçar uma diretriz no presente trabalho ${ }^{478}$.

Quando se tratar da discriminação de um único empregado, no momento da formação do contrato de trabalho, no curso deste ou por ocasião de sua cessação, ter-se-á uma lesão à direito meramente individual, não havendo que se falar em jurisdição metaindividual. Não há que se imaginar a existência de dano moral coletivo, ou outra lesão a direito difuso, coletivo ou individual homogêneo, em uma situação na qual um único empregado foi lesado. Por mais que a discriminação por sobrequalificação atinja interesses de toda a coletividade, como o

${ }^{477}$ Manoel Jorge e Silva Neto demonstra se filiar a esta corrente demasiadamente ampliativa ao assim se manifestar: "Se a discriminação no emprego ocorre relativamente aos que já se encontram na empresa, a hipótese é de transgressão a interesse coletivo dos empregados do estabelecimento; se, todavia, a consumação de tais práticas pelo empregador se dá no instante do processo de seleção dos novos empregados, parece claro que a circunstância está a caracterizar, ofuscantemente, ofensa a interesse difuso dos trabalhadores de uma maneira geral, posto que impossível delimitar, no universo do mercado de trabalho, aqueles que poderão ser vítimas da discriminação.

(...).

Ainda que a discriminação tenha atingido um único empregado implica, em verdade, em desrespeito a interesse metaindividual pelas repercussões desencadeadas na empresa ou na comunidade.

(...)

Ocorrida no curso do contrato do trabalho ou mesmo antes da sua formalização, a atitude discriminatória sempre redunda em agravo a interesse transindividual trabalhista de caráter difuso ou coletivo. (SILVA NETO, Manoel Jorge. Proteção...op. cit., p. 172).

478 Esta opinião que parece ser comungada por Christiani Marques que assim se manifestou: "O candidato ou empregado discriminado injustamente poderá procurar o Ministério Público e oferecer sua representação, para que o Parquet verifique se o procedimento discriminatório noticiado é regra comum adotada na empresa. Nesta hipótese, o pleito terá caráter coletivo" (MARQUES, Christiani. Op cit, p. 75). 
interesse da coletividade na qualificação de seus integrantes para o trabalho, a repercussão da discriminação de um único empregado não pode ensejar a atuação de entes coletivos, sob pena de se banalizar o próprio conceito e a finalidade da jurisdição metaindividual.

Diversa é a situação da dispensa coletiva de professores mais titulados, para contratação de outros com formação inferior e, por conseguinte, menos onerosos aos cofres da instituição. Neste caso, a violação a dispositivos da constituição e do Plano Nacional de educação justifica uma ação coletiva, inclusive para pleitear indenização por dano moral coletivo, que na feliz definição do Procurador do Trabalho Xisto Tiago de Medeiros Neto caracterizam-se pela presença dos seguintes elementos:

(1) a conduta antijurídica (ação ou omissão) do agente, pessoa física ou jurídica;

(2) a ofensa significativa e intolerável a interesses extrapatrimoniais, identificados no caso concretos, reconhecidos e inequivocadamente compartilhados por uma determinada coletividade (comunidade, grupo, categoria ou classe de pessoas titular de tais interesses protegidos pela ordem jurídica);

(3) a percepção do dano causado, correspondente aos efeitos que, ipso facto, emergem coletivamente, traduzidos pela sensação de desvalor, de indignação, de menosprezo, de repulsa, de inferioridade, de descrédito, de desesperança, de aflição, de humilhação, de angústia ou respeitante a qualquer outra conseqüência de apreciável conteúdo negativo;

(4) nexo causal observado entre a conduta ofensiva e a lesão socialmente apreendida e repudiada ${ }^{479}$.

No exemplo dos professores, tem-se, inquestionavelmente, a presença destes quatro elementos. A conduta antijurídica consistente na modalidade de discriminação aqui estudada, que viola a um só tempo o direito a igualdade e ao desenvolvimento subjetivo do candidato. Uma ofensa significativa ao interesse coletivo da comunidade de que os professores mais capacitados sejam valorizados e contribuam na formação de outras gerações. A sensação de desvalor, de indignação, de menosprezo, de repulsa, de inferioridade, de descrédito, de desesperança, de aflição, de humilhação, de angústia, causada a toda a

${ }^{479}$ MEDEIROS NETO, Xisto Tiago de. Dano moral coletivo. São Paulo: LTr, 2004, p. 138. 
sociedade que passa a não confiar mais na qualificação profissional como forma de aumentar sua empregabilidade e o nexo causal entre os elementos anteriores.

Importa destacar que a condenação em dano moral coletivo não afasta o direito dos empregados discriminados em razão de sua sobrequalificação de pleitear reintegração ou reparações individuais por eventuais danos sofridos. 


\section{CONSIDERAÇÕES FINAIS.}

O tema desenvolvido é atual e pouco estudado, o que tornou o seu estudo extremamente prazeroso e desafiador, mas também bastante difícil. Há ainda um grande desconhecimento acerca da ilicitude da conduta que aqui se chamou de discriminação por sobrequalificação. Embora se comente, geralmente de forma crítica e reprovadora, a ocorrência de hipóteses concretas deste ilícito, praticamente nenhuma medida é tomada para combatê-la. A questão, via de regra, é tratada como uma política econômica reprovável, porém não irregular, do empregador, o que consiste em um grande equívoco. O fato de o empregado sobrequalificado em geral não ser discriminado em decorrência de preconceito, mas por razões econômicas ou por temor de perda de espaço, não retira a ilicitude desta forma de tratamento desigual injustificado e desarrazoado.

A falta de combate a esta prática torna difícil dimensionar o problema. Sabe-se que ela existe. Não se pode, porém, pecisar o seu tamanho. Este trabalho objetivou, outrossim, demonstrar a ilicitude desta prática e a apresentar sugestões para o seu combate.

A irregularidade estudada subverte a antiga lógica de que qualificação é fator de empregabilidade e a de que, por essa razão, o desemprego tende a ser maior entre os trabalhadores menos qualificados. Com isso, a proliferação deste tipo de conduta certamente gerará um desestímulo ao investimento em educação, qualificação e formação profissional o que colocará o Brasil na contramão do progresso.

Isso sem falar nos danos que causa para a vítima. Ora, Num contexto em que o número de empregos não qualificados tende a aumentar mais do que o número de empregos qualificados, impedir alguém de se candidatar ou 
despedi-lo arbitrariamente porque é mais qualificado do que o cargo que ocupa, configura inequívoca violação ao seu direito ao trabalho. Afinal, o que fará o trabalhador que não consegue encontrar emprego correspondente a sua qualificação e não é aceito em funções menos qualificadas do que a sua?

Há que se considerar, contudo, que a simples opção por um trabalhador menos qualificado para a função, a escolha de um empregado com currículo menos expressivo para determinada promoção ou a dispensa de um empregado menos titulado quando haviam outros mais titulados não caracteriza, por si só, uma discriminação por sobrequalificação. Pode haver situações em que a preferência pelo empregado menos qualificado se justifique por outras razões, como, v.g., o fato dele gozar de maior confiança do empregador ou de ser mais vocacionado para aquela atividade menos qualificada do que os empregados mais titulados. Não é possível concluir de maneira absoluta que sempre que se preferir um empregado menos qualificado ao mais qualificado haverá uma discriminação, muito menos que isto deva ser presumido. É preciso muita cautela ao se analisar supostos casos de discriminação por sobrequalificação. Pode haver casos em que conquanto o empregador tenha possibilitado ao empregado sobrequalificado todas as oportunidades de concorrer a uma vaga com outros menos qualificados, optou, por razões não discriminatórias, pela contratação de trabalhador com menos formação.

Quando devidamente caracterizada, a discriminação por sobrequalificação viola o princípio-regra da dignidade da pessoa humana, desrespeita o direito da vítima ao desenvolvimento subjetivo em suas três vertentes, direito à educação, ao trabalho e à formação profissional, e fere o seu direito à igualdade. Como toda modalidade de descriminação no trabalho, consiste em uma violação de um direito humano que provoca desperdício de talento e efeitos prejudiciais na produtividade e no crescimento econômico. Pode, por conseguinte, ser combatida com a adoção da teoria da horizontalização dos direitos fundamentais, independentemente de previsão legal expressa. No Brasil, deve ser combatida com a aplicação das cominações da Lei 9.029/95, cujo rol de hipóteses de discriminação é exemplificativo e não taxativo. 
A discriminação por sobrequalificação perpetrada no momento do recrutamento e no curso do contrato de trabalho, assim como a praticada no momento da extinção da relação de emprego, além de afrontar os direitos da vítima ao desenvolvimento e à igualdade, constitui hipótese típica de exercício abusivo de um direito, de inobservância da função social do contrato, violando-se e de violação ao princípio da boa-fé objetiva.

Conquanto seja tão ilícita quanto a discriminação por sobrequalificação ocorrida ao término do contrato a discriminação por sobrequalificação verificada na formação do contrato de trabalho não pode ensejar a reintegração do empregado, como deve acontecer nas hipóteses daquela, vez que ainda não houve a formação do vínculo empregatício. Por outro lado, a reintegração é desnecessária no que se refere à discriminação praticada no curso do contrato de trabalho, haja vista que nesta hipótese o empregado encontra-se laborando normalmente. Nos casos em que a reintegração não for possível, a solução deverá ser a aplicação de uma sanção pecuniária.

Também não parece razoável impor ao empregador a contratação do empregado discriminado, pois isto afrontaria a liberdade de contratação do empregador. Há que se lembrar que não se vem defendendo o direito do empregado sobrequalificado ao posto vago, mas o seu direito a não ser exclú́do do processo seletivo por sua maior formação.

Diferente, entretanto, é a situação do empregado preterido em promoção em razão de sua maior formação, pelo menos quando houver na empresa plano de cargos e salários. Neste caso, é possível obter via reclamação trabalhista o novo enquadramento ou reclassificação, nos termos da Súmula 127 do Tribunal Superior do Trabalho. Em todos os casos é possível ajuizar ação para pleitear reparação por danos morais.

As normas coletivas também podem desempenhar um importante papel no combate à discriminação por sobrequalificação haja vista o desconhecimento que ainda paira sobre a discriminação por sobrequalificação e do equivocado dogma de que a liberdade de contratação e o poder diretivo do empregador 
permitem-lhe dispensar e preterir empregados sobrequalificados ao seu bel-prazer. A inclusão de cláusulas vedando a discriminação por sobrequalificação em normas coletivas pode ser fundamental no combate a este tipo de conduta perniciosa.

Defendeu-se aqui que as ações relativas à hipóteses de discriminação por sobrequalificação podem, perfeitamente, ser solucionadas pela distribuição ordinária do ônus da prova, prevista nos artigos 818 da CLT e 333 do Código de Processo Civil. Alegando o autor ter sido vítima deste ilícito trabalhista, cabe-lhe provar ter sido preterido na contratação ou na promoção por outro candidato ou outro empregado menos qualificado, ou ter sido dispensado quando havia outros empregados menos qualificados que poderiam sê-lo em seu lugar, fato constitutivo de seu direito à reintegração, ao enquadramento ou a indenização. Sendo certo que o ordinário se presume e o extraordinário deve ser provado, e neste caso o ordinário é a contratação do mais qualificado e a dispensa do menos qualificado, caberá ao réu provar que sua escolha não foi discriminatória, apresentando fatos modificativos, impeditivos ou extintivos do direito do autor.

Mesmo quando o empregado não possuir documentos que comprovem suas assertivas, melhor do que falar em inversão do onus probandi será fazer um requerimento na petição inicial para que o juiz determine que a parte contrária os junte sob pena de confissão.

A discriminação por sobrequalificação poderá ainda ser combatida ou reparada através da jurisdição metaindividual. É preciso, contudo, analisar com cautela os impactos da conduta discriminatória para se determinar se houve violação a um interesse difuso, coletivo ou individual homogêneo que justifique a intervenção do Ministério Público do Trabalho, ou se a hipótese é de violação a um direito individual ou individual heterogêneo que somente possa ser protegido pelas vítimas ou representantes.

O presente trabalho não tem a pretensão de esgotar o tema, cujo estudo ainda se inicia. Não poderia. O seu escopo é contribuir para conscientizar a comunidade acadêmica acerca da ilicitude da prática estudada e da necessidade de seu combate. Somente com essa conscientização e com esse combate 
será possível aprofundar os estudos sobre o tema. Esse escrito não representa, portanto, um ponto final. Apenas as primeiras aspas. 


\section{REFERÊNCIAS BIBLIOGRÁFICAS}

ALEXY, Robert. Teoria de los derechos fundamentales. Centro de Estudios Políticos y Fundamentales: Madrid, 2001.

AMOR, Abdelfattah. Rapport Introductif. In Les droits fondamentaux: universalité et diversité; Droit au développement; Démocratie et État de Droit; Commerces illicites. Bruxelles: Emile Bruylant: 1997, p. 31/40).

ARISTÓTELES. Politica. (tradução de Politikón, cotejada com a tradução inglesa de Benjamim Jowet e a tradução francesa de M. Thurot). São Paulo: 2006, p. 126.

ARNS, Cardeal Dom Paulo Evaristo. Para que todos tenham vida. In: Discriminação: estudos.Viana, Márcio Túlio e Renault, Luiz Otávio Linhares (coord). São Paulo: LTr, 2000, p. $13 / 27$.

ASSIS, José Carlos de. Trabalho como direito: fundamentos para uma política econômica de promoção do pleno emprego no Brasil. Rio de Janeiro: Contraponto, 2002.

BARCELlOS, Ana Paula de. A eficácia Jurídica dos Princípios Constitucionais: $O$ Princípio da Dignidade da Pessoa Humana. Rio de Janeiro: Renovar, 2002.

BARROS, Alice Monteiro de. Discriminação no emprego por motivo de sexo. In:Discriminação: estudos. Márcio Túlio Viana, Luiz Otávio Linhares Renault (coord). São Paulo: LTr, 2000, pp. 36/76.

BARROSO, Luís Roberto. Constituição da República Federativa do Brasil anotada. $5^{\text {a }}$ edição. São Paulo: Saraiva, 2006.

. Razoabilidade e isonomia no direito brasileiro. In:

Discriminação: estudos. Márcio Túlio Viana, Luiz Otávio Linhares Renault (coord).

São Paulo: LTr, 2000, pp. 28/35. 
BELLINTANI, Leila Pinheiro. “Ação Afirmativa” e os princípios do direito: a questão das quotas raciais para ingresso no Ensino Superior no Brasil. Rio de Janeiro: 2006.

BOBBIO, Norberto. Igualdade e liberdade. $2^{\mathrm{a}}$ edição. Rio de Janeiro: Ediouro, 1997, p.7.

BOUCINHAS FILHO, Jorge Cavalcanti. Ações afirmativas e inserção das pessoas portadoras de deficiência no mercado de trabalho. In: Revista da Faculdade de Direito/Universidade de São Paulo, v. 100, 2005. São Paulo: Serviço Técnico de Imprensa da Faculdade de Direito da Universidade de São Paulo: 2005, pp. 493/593.

BRITO FILHO, José Cláudio Monteiro de. Discriminação no trabalho. São Paulo: LTr, 2002.

BURGOS, Pedro. Diploma não dá dinheiro. In: Superinteressante, n. 245, nov. 2007. São Paulo: Editora Abril, p. 25.

CAMPOS, Julia. Igualdade e não discriminação no direito do trabalho. In: IV Congresso Nacional de direito do trabalho. Coimbra: Livraria Almedina, 2002, pp. $268 / 321$.

CARLOS, Vera Lúcia. Discriminação nas relações de trabalho. São Paulo: Editora Método, 2004.

CARVALHO, Catarina Oliveira. Considerações sobre o estatuto jurídico-laboral da mulher. In: IV Congresso Nacional de direito do trabalho. Coimbra: Livraria Almedina, 2002, p.129-158.

CHAVES, Daniela Lustoza Marques de Souza. Mercado de trabalho e discriminação etária: a vulnerabilidade dos trabalhadores envelhecentes. São Paulo: LTr, 2006.

COMPARATO, Fábio Konder. A afirmação histórica dos direitos humanos. São Paulo: Saraiva, 2001. 
CORREIA, Marcus Orione Gonçalves. Direitos Humanos e Direitos Sociais: Interpretação Evolutiva e Segurança Social. In: Revista do Departamento de Direito do Trabalho e da Seguridade Social. São Paulo, Departamento de Direito do Trabalho e da Seguridade Social da Faculdade de Direito da USP, v.1, n.1, jan/jun 2006, pp. 17/135.

DIMOULIS, Dimitri e MARTINS, Leonardo. Teoria Geral dos direitos fundamentais. São Paulo: RT, 2007.

DRAY, Guilherme Machado. O princípio da igualdade no direito do trabalho: sua aplicabilidade no domínio específico da formação de contratos individuais de trabalho. Coimbra: Almedina 1999.

DUMONT, René e PAQUET, Charlotte. Miséria e desemprego. Liberalismo ou democracia. Tradução: Vaso Casimiro. Lisboa: Instituto Piaget, 1994.

EHREINREICH, Barbara. Desemprego de colarinho branco. (trad.) Ana Maria Mandim. Rio de Janeiro: Record, 2006.

FERREIRA, Aurélio Buarque de Holanda. Novo dicionário da língua portuguesa. $3^{\mathrm{a}}$ edição. Curitiba: Positivo, 2004.

FERREIRA FILHO, Manoel Gonçalves. Direitos humanos fundamentais. $7^{\mathrm{a}}$ edição. São Paulo: Saraiva, 2005.

FREITAS JÚNIOR, Antônio Rodrigues de. Direito do trabalho na era do desemprego. Instrumentos jurídicos em políticas públicas de fomento à ocupação. São Paulo: LTr, 1999.

FUNDAÇÃO NACIONAL DE DESENVOLVIMENTO DO ENSINO SUPERIOR PARTICULAR (FUNDANESP). Legislação e Normas da Pós-Graduação Brasileira. $3^{\mathrm{a}}$ edição. Brasília: FUNDANESP, 2007. 
FURTADO, Emmanuel Teófilo. Preconceito no Trabalho e a Discriminação por Idade. São Paulo: LTr, 2004, p . 120.

GANDINI, Jean-Jacques. Les droit de l'homme. Paris: Librio, 2003.

GASPARINI, Diógenes. Direito Administrativo. $11^{\mathrm{a}}$ edição. São Paulo: Saraiva, 2006, p. 6 .

GHIONE, Hugo Barretto. Formação profissional a cargo do empregador: (releitura do direito do trabalho tendo em vista a adaptação do empregado na execução do trabalho). São Paulo: LTr, 2003.

GOMES, Benedito Barbosa. As ações afirmativas e os processos de promoção da igualdade efetiva. In: SEMINÁRIO internacional - as minorias e o direito. Cadernos do CEJ, n. 24, Centro de estudos judiciários, p. 97.

- Ação afirmativa \& princípio constitucional da igualdade: o direito como instrumento de transformação social. Rio de Janeiro: Renovar, 2001, p. 39.

GORZ, André. O imaterial, conhecimento, valor e capital. São Paulo: Annablume, 2005.

GUIMBO, Bernard Raymond. Droit au développment et dignité humaine. In Les droits fondamentaux: universalité et diversité; Droit au développement; Démocratie et État de Droit; Commerces illicites. Bruxelles: Emile Bruylant: 1997, p.73/89)

IZZI, Daniela. Eguaglianza e differenze nei rapporti di lavoro: il diritto antidiscriminatorio tra genere e fattori di rischi emergenti. Casa Editrici Jovene: Napoli, 2005.

JAKUTIS, Paulo. Manual de estudo da discriminação no trabalho: estudos sobre discriminação, assédio moral e ações afirmativas, por meio de comparações entre o Direito do Brasil e dos Estados Unidos. São Paulo: LTr, 2006. 
LAFER, Celso. A reconstrução dos direitos humanos: um diálogo com o pensamento de Hanna Arendt. São Paulo: Compahia das Letras, 1988.

LEDUR, José Felipe. A realização do direito ao trabalho. Porto Alegre: Sérgio Antonio Fabris Editor, 1998.

LEVINET, Michel. Recherche sur les fondements $d u<<$ droit au développement de l'être humain $>>$ à partir de l'exemple de la Convention européene des droits de l'homme. In Les droits fondamentaux: universalité et diversité; Droit au développement; Démocratie et État de Droit; Commerces illicites. Bruxelles: Emile Bruylant: 1997.

LIMA, Firmino Alves de. Mecanismos antidiscriminatórios nas relações de trabalho. São Paulo: LTr, 2006.

LIMA, Francisco Gérson Marques de. Igualdade de tratamento nas relações de trabalho. Anotação à Lei 9.029/95 em confronto com as Leis ns. 9.263/96, 7.716/89, 7.437/85 e 9.459/97 (aspectos trabalhistas e penais). São Paulo: Malheiros, 1997.

LINHARES, Paulo Afonso. Direitos fundamentais e qualidade de vida. São Paulo: Iglu, 2002

LOBATO, Marthius Sávio Cavalcante. O valor constitucional para a efetividade dos direitos sociais nas relações de trabalho. São Paulo: LTr, 2006.

LORENTZ, Lutiana Nacur. A norma da igualdade e o trabalho das pessoas portadoras de deficiência. São Paulo: LTr, 2006.

MAGANO, Octávio Bueno. Do poder diretivo na empresa. São Paulo: Saraiva, 1982. 
MAGANO, Octávio Bueno e MALLET, Estêvão. $O$ direito do trabalho na Constituição. Rio de Janeiro: Forense, 1993.

MALLET, Estêvão. Direito do trabalho e discriminação. In: Fórum Internacional sobre Direitos Humanos e Direitos Sociais. São Paulo: LTr, 2004. p. 355.

MARCONDES, Roberto Rangel. O princípio da isonomia, a dignidade humana e a proteção da pessoa portadora do H.I.V./AIDS. Monografia apresentada como requisito para conclusão do $4^{\circ}$ Curso de Especialização em Interesses Difusos e Coletivos Escola Superior do Ministério Público de São Paulo, sob a orientação do Prof. Dr. Vidal Serrano Nunes Júnior. São Paulo: 2000.

MARIETTO, Leonardo. O direito civil constitucional e a nova teoria dos contratos. In: TEPEDINO, Gustavo (coord). Problemas de direito civil constitucional. Rio de Janeiro: Renovar, 2001.

MARQUES, Christiani. O contrato de trabalho e a discriminação estética. São Paulo: LTr, 2002.

MARTINEZ, Pedro Romano Martinez. Direito do Trabalho. Coimbra: Almedina, 2002

MEDEIROS NETO, Xisto Tiago de. Dano moral coletivo. São Paulo: LTr, 2004.

MELLO, Celso Antônio Bandeira de. Conteúdo jurídico do princípio da igualdade. $3^{\mathrm{a}}$ edição, 14 ${ }^{\mathrm{a}}$ edição. São Paulo: Malheiros, 2006.

. Curso de direito administrativo. $12^{\mathrm{a}}$ edição. São

Paulo: Malheiros, 2000.

MELO, Sandro Nahmias. O direito ao trabalho da pessoa portadora de deficiência: $o$ princípio constitucional da igualdade: ação afirmativa. São Paulo: LTr, 2004. 
MERINO, Lucyla Tellez. Direitos humanos e direito do trabalho: enfoques humanistas na proteção dos direitos sociais. 2006. 306 f. Dissertação (Mestrado em Direito). Faculdade de Direito. Universidade de São Paulo, São Paulo.

MERLET, Philippe (diréction générale). Le petit larousse illustré. 100em édition. Montreal, 2004.

MIRANDA, Jorge de. Manual de direito constitucional. $3^{\mathrm{a}}$. Edição. Coimbra: Coimbra Editora, 1996, tomo II.

MONTEIRO, Washington de Barros. Curso de direito civil, v. 1: parte geral. São Paulo: Saraiva, 2007.

MORAES, Alexandre de. Direito constitucional. 15a edição. São Paulo: Atlas, 2004, p. 62.

MORAES, Maria Celina Bodin de. O conceito de dignidade humana: substrato axiológico e conteúdo normativo. In: SARLET, Ingo Wolfgang (Org). Constituição, Direitos Fundamentais e Direito Privado. Porto Alegre: Livraria do Advogado, 2003, p. $105-148$.

NOBRE JÚNIOR, Edílson Pereira. Direitos fundamentais $e$ argüição de descumprimento de preceito fundamental. Porto Alegre, Sérgio Antonio Fabris, 2004. . Princípio da boa-fé e sua aplicação no direito administrativo brasileiro. Porto Alegre: 2002.

OLEA, Manuel Alonso e BAAMONDE, Emilia Casas. Derecho Del Trabajro. Decimoctava edición. Civitas Edición, Madrid, 2000.

OLIVEIRA, Oris de. Trabalho e profissionalização do jovem. São Paulo: LTr, 2004.

ORGANIZAÇÃO INTERNACIONAL DO TRABALHO (OIT). La igualdad en el trabajo: afrontar los retos que se plantean. Informe global con arreglo al seguimiento 
de la Declaración de la OIT relativa a los princípios e derechos fundamentales relativos al trabajo. 96 Reunião Anual da Organização do Trabalho (OIT). Genebra, OIT, 2007, disponível em <http://www.ilo.org.br/info/downloadfile.php?fileId=261>. Acesso em 22 de outubro de 2007.

Manual de capacitação e informação sobre gênero, raça, pobreza e emprego: guia para o leitor. Brasília, OIT, 2005. 8v.

PASTORE, José. As mudanças no mundo do trabalho: leituras de sociologia do trabalho. São Paulo: LTr, 2006.

Oportunidades de trabalho para portadores de deficiência. São

Paulo: LTr, 2000.

PEDROSO, Marcelo Batuíra da C. Losso. Liberdade e irrenunciabilidade no direito do trabalho. Porto Alegre, Sergio Antonio Fabris Editor, 2005.

PELUZO, Cesar(coord). Código Civil Comentado. Barueri-SP, Manole, 2007, p. 312.

PIOVESAN, Flávia. Direitos Humanos e o Direito Constitucional Internacional. $7^{\mathrm{a}} \mathrm{ed}$. São Paulo: Saraiva, 2006.

. Discriminação. In: Fórum Internacional sobre Direitos Humanos e Direitos Sociais. São Paulo: LTr, 2004. p. 332-341). . Temas de Direitos Humanos. São Paulo:

Max Limonad. 1998.

RIFKIN, Jeremy. O fim dos empregos: o declínio inevitável do níveis dos empregos e a redução da força global de trabalho. Tradução: Ruth Gabriela Bahr. São Paulo: Pearson Education do Brasil, 2001, p. 4/5. 
RIOS, Roger Raupp. O princípio da igualdade e a discriminação por orientação sexual: a homossexualidade no direito brasileiro e norte-americano. São Paulo: Editora Revista dos Tribunais, 2002.

RISTER, Carla Abrantkoski. Direito ao desenvolvimeno: antecedentes, significado e conseqüências. 2003. 445f. Tese (doutorado em Direito). Faculdade de Direito. Universidade de São Paulo, São Paulo.

ROCAMORA, Luis G. Martínez. Decisiones Empresariales y principio de igualdad. Barcelona: Cedecs Editorial S.L., 1998.

ROCHA, Carmem Lúcia Antunes. Ação Afirmativa. O conteúdo democrático do Princípio da Igualdade Jurídica. In: Revista de Informação Legislativa, ano 33, N. 131. Brasília. Julho/setembro de 1996).

RODRIGUEZ, Américo Plá. Princípios do direito do trabalho. (tradução de Wagner

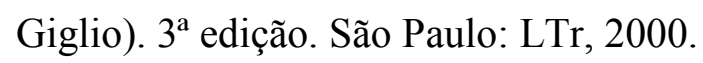

ROJO, Eduardo Caamaño. El derecho a la no discriminación en el empleo. Santiago: LexisNExis, 2005.

ROMITA, Aryon Sayão. Direitos fundamentais nas relações de trabalho. São Paulo: LTr, 2005.

ROTHENBURG, Walter Claudius. Princípios constitucionais. Sérgio Antonio Fabres Editor: Porto Alegre, 1999.

ROUSSEAU, Jean-Jacques. Discurso sobre a origem $e$ os fundamentos da desigualdade entre os homens. São Paulo: Martin Claret, 2006.

SARLET, Ingo Wolfgang. A eficácia dos direitos fundamentais. $3^{\mathrm{a}}$ edição. Porto Alegre: Livraria do Advogado Editora, 2003. 
. Dignidade da pessoa humana e direitos fundamentais na

Constituição Federal de 1988. Porto Alegre: Livraria do advogado editora, 2006.

SCHLEI, Bárbara Lindemann. Employment Discrimination Law. Second Edition. Chicago: American Bar Association, 1983.

SILVA, Ana Emília Andrade Albuquerque da. Discriminação racial no trabalho. São Paulo: LTr, 2005.

SILVA, José Afonso. Comentário contextual à Constituição. São Paulo: Malheiros, 2005 .

Paulo: Malheiros, 2003.

SILVA, Katia Elenise Oliveira da. O papel do direito penal no enfrentamento da discriminação. Livraria do advogado editora: Porto Alegre, 2001.

SILVA, Virgílio Afonso da. A constitucionalização do direito: os direitos fundamentais nas relações entre particulares. São Paulo: Malheiros, 2005.

SILVA NETO, Manoel Jorge e. Direitos fundamentais e contrato de trabalho. São Paulo: LTr, 2005. . Proteção constitucional dos interesses trabalhistas: difusos, coletivos e individuais homogeneos. São Paulo: LTr, 2001, p. 47.

SÜSSEKIND, Arnaldo. Direito Internacional do Trabalho. São Paulo: LTr, 1983.

TAVARES, André Ramos. Curso de direito constitucional. $5^{\text {a }}$ edição. São Paulo: Saraiva, 2007.

TEIXEIRA, Sérgio Torres. Proteção à relação de emprego. São Paulo: LTr, 1998, p. 16. 
TRINDADE, Antônio Augusto Cançado. A proteção internacional dos direitos humanos: fundamentos jurídicos e instrumentos básicos. São Paulo: Saraiva, 1991.

UNESCO. "Education for All”, Global Monitoring Report 2005. Paris: UNESCO, 2004. Disponível em:

$<$ http://www.unesco.org/education/gmr_download/en_summary.pdf $>$.

VALE, André Rufino do. Eficácia dos direitos fundamentais nas relações privadas. Porto Alegre: Sergio Antonio Fabris Ed., 2004.

VIANA, Márcio Túlio. A proteção trabalhista contra atos discriminatórios: onde termina o discurso e começa a realidade. In: VIANA, Márcio Túlio e RENAULT, Luiz Otávio Linhares (coord.). Discriminação. São Paulo: LTr, 2000, p. 354/367.

VIANNA, Cláudia Salles Vilela. Manual 'prático das relações trabalhistas. $8^{\mathrm{a}}$ edição. São Paulo: LTr, 2007.

VILHENA, Paulo Emílio Ribeiro. Relação de emprego. $3^{\mathrm{a}}$ edição. São Paulo: LTr, 2005.

WANDELLI, Leonardo Vieira. Despedida Abusiva. O direito (do trabalho) em busca de uma nova racionalidade. São Paulo: LTr, 2004.

http://www.archives.gov/national-archives-experience/charters/declaration_transcript. html

http://www.camara.cl/legis/constitucion/contitucion_politica.pdf

http://www.dhnet.org.br/direitos/sip/onu/spovos/lex170a.htm

http://www.di-elle.it/Leggi/91-125.htm

http://www.direitoshumanos.usp.br/counter/Onu/Sist_glob_trat/texto/texto_2.html 
http://www.eurofound.europa.eu/pubdocs/1997/42/pt/1/ef9742pt.pdf

http://www.ilo.org/ilolex/spanish/convdisp1.htm

http://www.ilo.org.br/info/downloadfile.php?fileId=261

http://www.info.gov.za/documents/constitution/1996/96cons2.htm

http://www.italianosenamerica.com/site/constituzione/costituzione.pdf

http://www.midiaindependente.org/pt/blue/2006/06/356928.shtml

http://www2.mre.gov.br/dai/m_592_1992.htm

http://www.oefre.unibe.ch/law/icl/sz00000 .html

http://www.di-elle.it/Leggi/91-125.htm

http://secretjurid.www5.50megs.com/leyes/lyspenal/23592_penal.htm

http://www.senado.gov.ar/web/interes/constitucion/atribuciones.php

http://www.senado.gov.ar/web/interes/constitucion/capitulo1.php

http://www.sindhosp.com.br/IMP_275e.html

http://www.sinduscon-mg.org.br/ass_jur/ccts_2004/adm_04.pdf

http://sttrbh.br.tripod.com/Sintesc2005.htm

http://www1.umn.edu/humanrts/instree/french/fzlafchar.html

http://www.unesco.org.br/publicacoes/copy_of_pdf/decjomtien 
http://www.unesco.org/education/gmr_download/en_summary.pdf

http://www.unhchr.ch/udhr/lang/por.htm

http://www.unicef.pt/docs/pdf_publicacoes/convencao_direitos_crianca2004.pdf 
ANEXO I - Entrevista realizada em agosto de 2007.

Nome completo: mantido em sigilo a pedido do entrevistado

Idade na ocasião da entrevista: 37 anos

Data de nascimento: 14/11/1969

Escolaridade: Pós-graduado/ nível = Mestrado

Profissão: Professor

\section{Questionário}

1) Qual o seu primeiro emprego? Bancário

2) Quantos anos você possuía na época? 20 anos

3) Qual era o seu grau de formação? $2^{\circ}$ grau completo

4) É graduado? Quando se graduou? 1994

5) Qual a sua área de formação (nome do curso)? História

6) Quantos anos possuía na época? 24 anos

7) Qual a sua maior formação? Quando a obteve? Mestrado, em 1997

8) Qual era o seu objetivo cursando mestrado? Aumentar meu grau de conhecimento e prestar algum tipo de seleção para professor

9) Após concluir o mestrado teve dificuldades para conseguir emprego? A que atribui estas dificuldades? Não, visto que no ano seguinte passei no concurso para professor substituto da UFRN

10) Após o término de seu contrato como professor substituto, procurou emprego em outras universidades?_Deixei meu currículo em algumas faculdades particulares

11) Qual o resultado obtido? No primeiro semestre só obtive promessas

12) Qual era a titulação requerida por estas Universidades? No mínimo, especialização

13) Procurou emprego em escolas de ensino médio ou fundamental? Por que razão? Também, visto não querer esperar pelo interesse das faculdades; precisava trabalhar

14) Apenas apresentou currículo ou chegou a fazer entrevistas? Ambos!

15) Qual o resultado das entrevistas? Frustrante pois, aquilo que eu pensava que seria 0 meu diferencial (mestrado/ experiência de 2 anos e meio como professor de nível superior) mostrou-se ao contrário, meu principal entrave.

16) Sentiu-se discriminado por possuir qualificação superior à necessária para o cargo? Sim!

17) Pensou em enviar currículo para outras escolas omitindo a sua pós-graduação e a experiência anterior como professor universitário? Não!

18) $\mathrm{O}$ fato de possuir mestrado facilitou o acesso às entrevistas/avaliações nas escolas ou dificultou? Dificultou!

19) Algum entrevistador chegou a afirmar que você era qualificado demais para o posto? Disseram-me, por duas vezes, que o meu currículo estava além do necessitado pelas escolas, que o meu grau de intelectualidade poderia ficar acima da compreensão dos alunos.

20) Algum entrevistador perguntou-lhe por que razão você desejava lecionar no ensino médio ou fundamental se já possuía mestrado concluído? Não

21) Você foi contratado por este entrevistador? Não

22) Tem conhecimento de outros professores que foram preteridos em escolas ou universidades por serem excessivamente qualificados? Não lembro

23) Poderia citar os nomes? Se passaram, ou não me disseram ou não me recordo

24) Poderia indicar onde eles podem ser contatados? 
25) Esses Professores ficaram desempregados por um longo período por serem excessivamente qualificados?

26) Como eles fizeram para retornar ao mercado de trabalho?

27) Você ainda tem interesse em lecionar no ensino médio e/ou fundamental? Por quê? Não. Primeiro, porque já tenho um certo reconhecimento pelo mercado; segundo, porque já estou tão envolvido com discussões em um nível mais complexo que acho que perderia enquanto evolução profissional e intelectual e terceiro, porque pretendo fazer seleção para doutorado e crescer mais dentro do meu campo de conhecimento.

28) Conhece professores com mestrado e doutorado que lecionam no ensino médio e fundamental por opção? Não!

29) Conhece professores que foram preteridos em universidades por possuírem mestrado/doutorado e estes títulos encarecerem o valor da hora/aula? Já tive várias informações de pessoas de dentro de uma universidade à qual lecionei por seis anos (Nome da Universidade mantido em sigilo), que esta prática estaria sendo adotada pela instituição e que, inclusive, eu seria um dos cotados. Não por coincidência, comecei a ser perseguido injustificadamente por uma coordenadora, de um dos cursos que lecionava, e num espaço de um semestre foi demitido sob o falacioso argumento de carga-horária insuficiente. 
ANEXO II - Entrevista realizada em agosto de 2007

Nome completo: mantido em sigilo a pedido do entrevistado.

Idade atual: 41

Data de nascimento: 23/08/1966

Escolaridade: Superior Completo

Profissão: Economista/Corretor

\section{Questionário}

30) Quando obteve o primeiro emprego?_Após estágio na CEF

31) Quantos anos possuía na época? 18 anos

32) Qual era o seu grau de formação? Colegial

33) Quando se graduou? 1991

34) Qual a sua área de formação (nome do curso)? Economia

35) Quantos anos possuía na época? _ 25 anos

36) Após a graduação teve dificuldades de conseguir emprego?_na época já trabalhava em um Banco privado

37) Em caso de resposta positiva à pergunta anterior, quanto tempo passou desempregado? 10 anos

38) Enquanto esteve desempregado participou de quantas seleções de emprego (pode ser número aproximado ou estimado)? aproximadamente 10 empresas. Após sair do Banco distribuí currículo por várias empresas, inclusive outros bancos, mas não passava da fase de entrevista

39) Estas seleções visavam contratação para que tipo de emprego?_Primeiro procurei emprego em outros bancos, por gostar de serviços bancários. Depois passei a buscar qualquer tipo de serviço.

40) Procurou empregos que não guardavam relação com a sua área de formação? Quais? __sim, _escriturário, auxiliar administrativo, tradutor, informática etc...

41) Procurou empregos que não demandavam formação de nível superior? Quais? sim, escriturário, auxiliar administrativo, tradutor, informática etc...

42) Por que procurou empregos que não exigiam nível superior ou não guardavam relação com sua área de formação? A princípio, compreendo que na minha área de formação seria muito difícil, pois na região de resido não existe muito emprego para economista, mas poderia trabalhar com projetos q tentei por um tempo, mas não deu certo, pois a empresa q montamos eu e dois amigos de curso não pagava nem as despesas. Resolvi para não ficar parado tentar outras possibilidades.

43) Quando procurava empregos que não exigiam formação de nível superior colocava no currículo que era graduado?

44) $\mathrm{O}$ fato de ser graduado facilitava o acesso às entrevistas/avaliações ou dificultava? em alguns casos nem era chamados para seleção, e em outros ouvia o entrevistado me perguntar: aaa vc é formado em economia né?

45) Algum entrevistador chegou a afirmar que você era qualificado demais para o posto ou perguntou porque alguém com tanta qualificação desejava um emprego que não demandava formação de nível superior? algumas vezes sim

46) Você foi contratado por este entrevistador? _ Não

47) $\mathrm{Na}$ seleção que finalmente resultou na sua contratação você havia incluído a sua formação universitária? _nas várias vezes em que fui contratado havia omitido o fato de ter nível superior, falar língua estrangeira e ter conhecimento maior que o básico de informática

48) Você já havia enviado currículo para o mesmo local incluindo a sua formação universitária?_Não 
49) Nesta chegou a c a ser a ntrevistado?

Prejudicada

50) Após a contratação comunicou aos superiores que possuía titulação maior do que a mencionada no currículo? _. Não

51) Qual foi a reação do seu superior?

52) Havia outros empregados com qualificação inferior à sua no local de trabalho? _ $\underline{\text { Só }}$ de ASG

53) Sentia alguma hostilidade da parte deles por você ser mais qualificado do que eles e mais qualificado do que as exigências da função ocupada? _uando trabalhava no banco, sentia uma certa rivalidade por partes do chefes de setor e da gerencia, até mesmo ouvi uma vez, quando estava perto de me formar o meu gerente administrativo falar que não valia a pena mandar meu diploma para o departamento pessoal, pois isso não iria mudar muito a minha função dentro do banco.

54) Baseado em que você percebia esta hostilidade? _Comportamento

55) Quanto tempo passou neste emprego? _ no banco, após formado uns 6 anos, mais ou menos.

56) Em quantos outros locais trabalhou após sair de lá?_04 (quatro)

57) Ao procurar esses outros empregos, mencionou que era graduado? _os que foram cargos comissionados no estado sim, nas empresas particulares não.

58) Por quê? _Alguns amigos me diziam que se eu tinha interesse em qualquer emprego, seria bom não informar que tinha alguma graduação para que não assustasse, pois geralmente pessoas graduadas ou com um pouco mais de informação são funcionários que reclamam mais direitos que os que têm menos informação. Pude confirmar que estes amigos tinham razão.

59) Ainda pretende trabalhar em sua área de formação? Por quê? _Não. Hoje tenho conhecimento técnico em transações imobiliárias e posso trabalhar como autônomo, acho mais confortável.

60) $\mathrm{Na}$ sua concepção, a formação universitária foi útil para a sua vida? Justifique. _. Para minha satisfação pessoal fui sim, profissional não tenho tanta certeza, hoje talvez seja diferente só q não tentei mais devido a idade e interesses outros.

61) Na sua concepção, a formação universitária ajudou o dificultou o seu ingresso no mercado de trabalho? Justifique. _dificultou, por várias razões, na época poucas pessoas tinha nível superior, pelo menos em várias das empresas que tive contato, acredito que algumas dessas pessoas se sentia ameaçadas por ter um funcionários de posição inferior com um pouco mais de conhecimento ou até com medo de ter um funcionário que reclamasse mais os direitos. 
ANEXO III - Entrevista realizada em setembro de 2007.

Nome: mantido em sigilo a pedido do entrevistado

Idade na data da entrevista: 31 anos

Data de Nascimento: 20/01/76

Profissão: Advogado e Professor Universitário

1) Quando obteve o primeiro emprego? 2000.

2) Quantos anos possuía à época? 25 anos.

3) Qual era o seu grau de formação? Superior completo.

4) Quando se graduou? 2000.

5) Quantos possuía à época da graudação? 24

6) Após a graduação teve dificuldade de conseguir emprego? Não

7) Qual o seu maior grau de formação? Mestrado.

8) Por que decidiu fazer mestrado? Aperfeiçoamento acadêmico

9) Quando concluiu o mestrado estava empregado? Sim

10) O que fazia na época? Era advogado em uma grande empresa

11) Ainda trabalha nesta empresa? Não

12) Por que acha que foi dispensado? Reformulação da política interna

13) Procurou emprego em empresas congêneres? Sim

14) Enviou currículo? Sim. Após haver sido indicado por um amigo

15) Como foi o processo seletivo? Análise currícular e duas entrevistas

16) Qual foi o resultado do processo seletivo? Não fui contratado

17) Informou em seu currículo que era mestre? Sim

18) Acha que este fato facilitou ou dificultou o recrutamento? As duas coisas. Facilitou no começo e depois dificultou

19) Por quê? Facilitou porque a primeira entrevista foi feita com uma pessoa que valorizava a formação acadêmica. Dificultou porque a segunda entrevistadora entendeu que eu poderia me desestímular com o trabalho porque vinha de uma formação acadêmica superior

20) Ela mencionou isso na entrevista? Sim

21) Como ela falou? Ela perguntou: "Será que depois de ter feito mestrado, você não achará o trabalho na empresa uma atividade repetitiva e desestimulante?"

22) E o que você respondeu? Falei que dependeria de como fossem colocadas as metas. Que na verdade isso independeria da titulação acadêmica. Que dependeria mais dos objetivos e das metas propostas para o trabalho.

23) Essa entrevistadora seria sua superiora imediata se você fosse contratado? Sim.

24) Durante a entrevista foi esclarecido qual era a formação acadêmica dela? Ela disse que estava fazendo especialização.

25) Ela era mais jovem que você? Aparentava ser da mesma idade.

26) Em sua opinião o fato de você possuir uma titulação mais alta do que a dela obstou ou atrapalhou a contratação? Acho que atrapalhou.

27) Por quê? Talvez por ela ter se sentido ameaçada.

28) Ameaçada em que sentido? No sentido de não conseguir impor autoridade por meio do conhecimento que tem.

29) Você acha que ela pode ter sentido medo de no futuro perder o cargo para você? Acho que é possível.

30) Ainda está desempregado? Sim. 